Nevada

Environmental

Restoration

Project

Post-Closure Report for Closed

Resource Conservation and

Recovery Act Corrective Action

Units, Nevada National Security

Site, Nevada

For Fiscal Year 2010

(October 2009-September 2010)

Controlled Copy No:

Revision: 0

January 2011

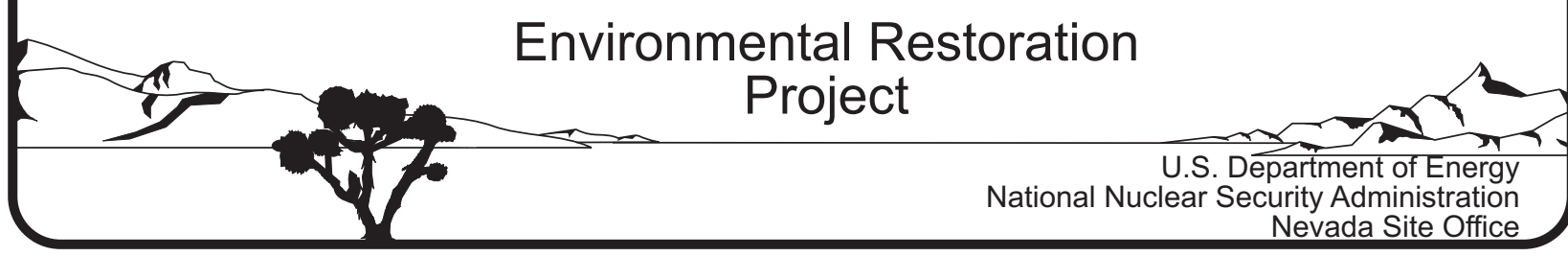




\section{DISCLAIMER}

Reference herein to any specific commercial product, process, or service by trade name, trademark, manufacturer, or otherwise, does not necessarily constitute or imply its endorsement, recommendation, or favoring by the U.S. Government or any agency thereof.

This report has been reproduced directly from the best available copy.

Available for sale to the public from:

U.S. Department of Commerce

National Technical Information Service

5301 Shawnee Road

Alexandria, VA 22312

Telephone: (800) 553-6847

Fax: (703) 605-6900

E-mail: orders@ntis.gov

Online ordering: http://www.ntis.gov/help/ordermethods.aspx

Available electronically at http://www.osti.gov/bridge.

Available for a processing fee to the U.S. Department of Energy and its contractors, in paper, from:

U.S. Department of Energy

Office of Scientific and Technical Information

P.O. Box 62

Oak Ridge, TN 37831-0062

Telephone: (865) 576-8401

Fax: (865) 576-5728

E-mail: reports@adonis.osti.gov 


\title{
POST-CLOSURE REPORT FOR CLOSED RESOURCE CONSERVATION AND RECOVERY ACT CORRECTIVE ACTION UNITS, NEVADA NATIONAL SECURITY SITE, NEVADA \\ FOR FISCAL YEAR 2010 \\ (OCTOBER 2009-SEPTEMBER 2010)
}

\author{
U.S. Department of Energy, \\ National Nuclear Security Administration \\ Nevada Site Office \\ Las Vegas, Nevada
}

Controlled Copy No.

Revision: 0

January 2011 
THIS PAGE INTENTIONALLY LEFT BLANK 


\section{POST-CLOSURE REPORT FOR CLOSED RESOURCE CONSERVATION AND RECOVERY ACT CORRECTIVE ACTION UNITS, NEVADA NATIONAL SECURITY SITE, NEVADA}

FOR FISCAL YEAR 2010 (OCTOBER 2009-SEPTEMBER 2010)

Approved By: $\begin{aligned} / \mathrm{s} /: \text { Kevin Cabble } & \text { Kevin J. Cabble } \\ & \text { Federal Sub-Project Director } \\ & \text { Industrial Sites Sub-Project }\end{aligned}$

Approved By: $\begin{aligned} & \frac{\text { SS/: Robert F. Boehlecke }}{\text { Robert F. Boeklecke }} \\ & \text { Federal Project Director } \\ & \text { Environmental Restoration Project }\end{aligned}$ Date: 
THIS PAGE INTENTIONALLY LEFT BLANK 


\section{TABLE OF CONTENTS}

ACRONYMS AND ABBREVIATIONS ………….............................................................. vii

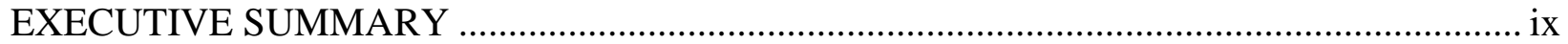

1.0 SUMMARY OF INSPECTIONS, REPAIRS, AND MAINTENANCE................................ 1

1.1 CoRRECTIVE ACTION UNIT 90, AREA 2 BitCUTTER ConTAINMENT ………………........ 1

1.1.1 Permit Requirements .............................................................................. 1

1.1.2 Inspection, Repair, and Maintenance Activities ............................................... 1

1.2 CoRrective Action Unit 91, AREA 3 U-3Fi InJeCtion WeLL..................................... 1

1.2.1 Permit Requirements ................................................................................. 1

1.2.2 Inspection, Repair, and Maintenance Activities ................................................ 1

1.3 CoRrective Action Unit 92, AREa 6 DeCon Pond FACILITY .................................... 1

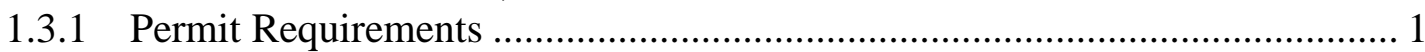

1.3.2 Inspection, Repair, and Maintenance Activities ............................................... 2

1.4 Corrective Action Unit 110, AREA 3 WMD U-3AX/BL Crater ............................. 2

1.4.1 Permit Requirements ............................................................................. 2

1.4.2 Inspection, Repair, and Maintenance Activities ............................................... 3

1.5 Corrective Action Unit 112, Area 23 Hazardous Waste Trenches .................. 3

1.5.1 Permit Requirements ..................................................................................... 3

1.5.2 Inspection, Repair, and Maintenance Activities ................................................. 3

2.0 CORRECTIVE ACTION UNIT 110 SUBSIDENCE AND VEGETATION SURVEY

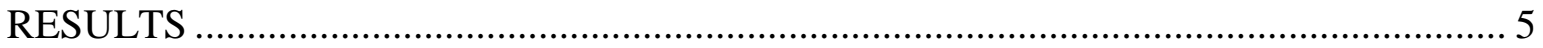

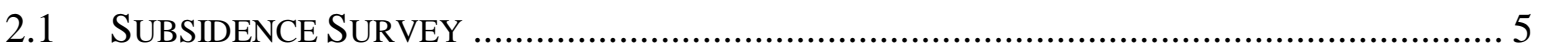

2.2 VEGETATION SURVEY........................................................................................ 5

3.0 CORRECTIVE ACTION UNIT 110 SOIL MOISTURE MONITORING RESULTS ........ 9

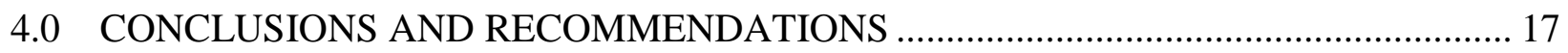

4.1 CoRrective ACTION Unit 90, AREA 2 BitcutTER ConTAINMENT ............................. 17

4.2 Corrective Action Unit 91, AREA 3 U-3fi InJECTION WeLL................................... 17

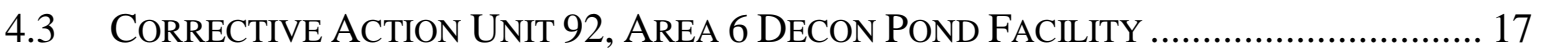

4.4 Corrective Action Unit 110, AREA 3 WMD U-3AX/Bl Crater ............................. 17

4.5 Corrective Action Unit 112, AREA 23 HaZARdous Waste TRENCHES ................. 17

LIBRARY DISTRIBUTION LIST

\section{FIGURES}

Figure 1. LOCATIONS Of ClOSED ReSOURCE CONSERVATION AND RECOVERY ACT CORRECTIVE ACTION SITES.................................................................................................. X

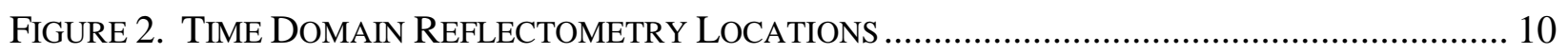

Figure 3. Precipitation Data for Meteorological Station Buster Jangle Y .................. 11

Figure 4. East TDR Nest A Soil Moisture Content Profile ................................................. 12

Figure 5. East TDR Nest B SoIL Moisture Content Profile ………................................... 13

Figure 6. WeSt TDR NeSt A Soil Moisture Content Profile ............................................... 14

FiguRe 7. West TDR Nest B Soil Moisture Content Profile ……………........................... 15 
Date: January 2011

\section{TABLE OF CONTENTS (continued)}

TABLES

TABle 1. Corrective Action Unit 110 Subsidence SurVey ResUlts .................................. 6

\section{APPENDICES}

APPENDIX A. INSPECTION CHECKLISTS

APPENDIX B. FIELD NOTES

ApPENDIX C. PHOTOGRAPHS 
Date: January 2011

\section{ACRONYMS AND ABBREVIATIONS}

CAU

FFACO

$\mathrm{ft}$

in.

NDEP

SM

TDR

\section{Corrective Action Unit}

Federal Facility Agreement and Consent Order

foot (feet)

inch(es)

Nevada Division of Environmental Protection

subsidence marker

Time Domain Reflectometry 
RCRA Post-Closure Report

Revision: 0

Date: January 2011

THIS PAGE INTENTIONALLY LEFT BLANK 


\section{EXECUTIVE SUMMARY}

This report serves as the combined annual report for post-closure activities for the following closed Corrective Action Units (CAUs):

- CAU 90, Area 2 Bitcutter Containment

- CAU 91, Area 3 U-3fi Injection Well

- CAU 92, Area 6 Decon Pond Facility

- CAU 110, Area 3 WMD U-3ax/bl Crater

- CAU 112, Area 23 Hazardous Waste Trenches

The locations of the sites are shown in Figure 1. This report covers fiscal year 2010 (October 2009-September 2010). The post-closure requirements for these sites are described in Resource Conservation and Recovery Act Permit Number NEV HW0021 and summarized in each CAU-specific section in Section 1.0 of this report.

Site inspections are conducted semiannually at CAUs 90 and 91 and quarterly at CAUs 92, 110, and 112. Additional inspections are conducted at CAU 92 if precipitation occurs in excess of 0.50 inches in a 24-hour period. Inspections include an evaluation of the condition of the units and identification of any deficiencies that may compromise the integrity of the units. The condition of covers, fencing, signs, gates, and locks is documented. In addition, soil moisture monitoring and subsidence surveys are conducted at CAU 110. The results of the inspections, summary of maintenance activities, results of vegetations surveys, and analysis of monitoring data are presented in this report.

Copies of the inspection checklists are included as Appendix A. Field notes completed during each inspection are included in Appendix B. Photographs taken during the site inspections are included in Appendix C. 


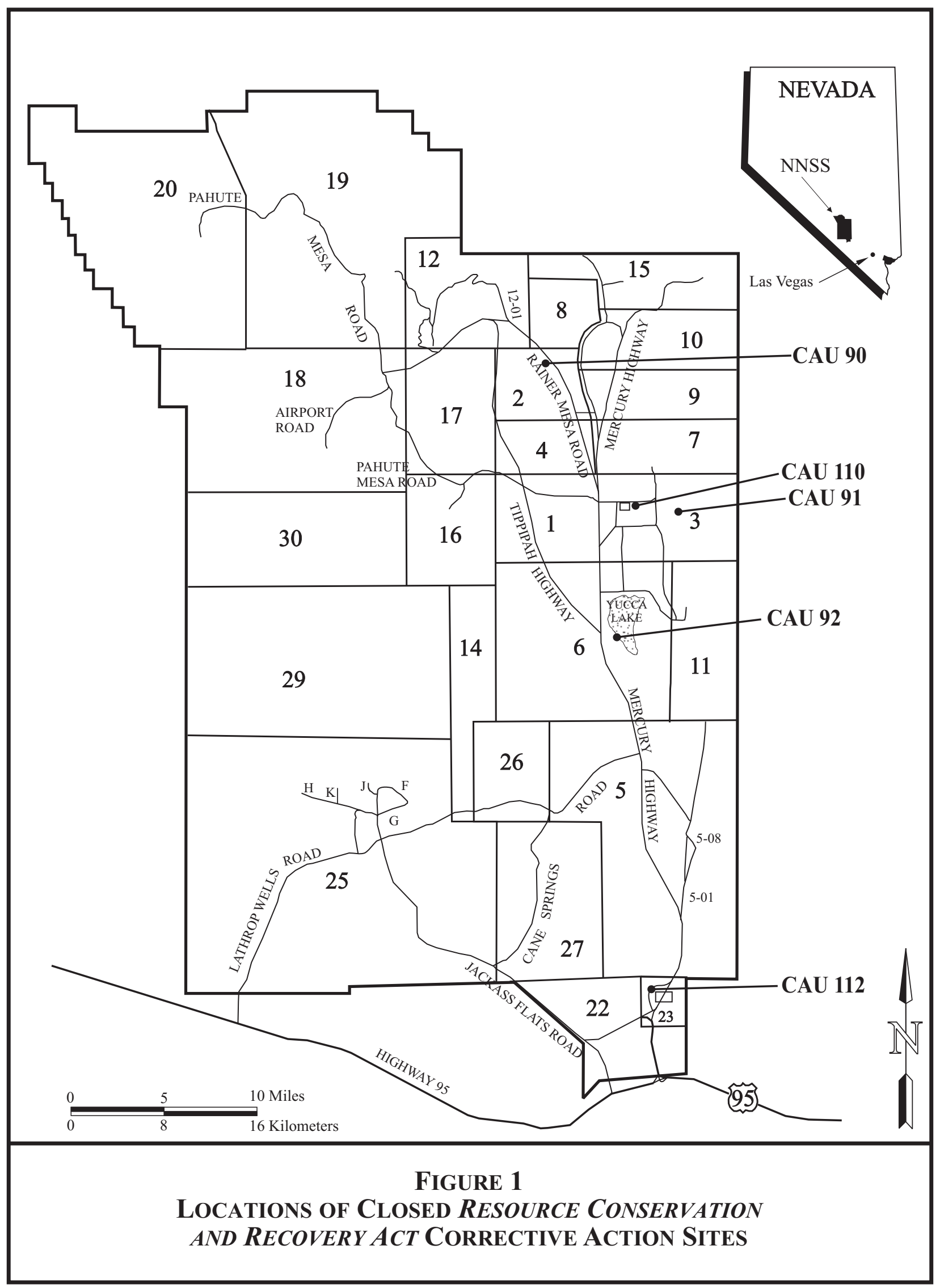




\subsection{SUMMARY OF INSPECTIONS, REPAIRS, AND MAINTENANCE}

\subsection{Corrective Action Unit 90, AREA 2 BitcutTer Containment}

\subsubsection{Permit Requirements}

Semiannual inspections are required at Corrective Action Unit (CAU) 90 to evaluate the condition of the unit and identify deficiencies that may compromise the unit's integrity. Photographs are taken, and the results of the inspection are documented on a checklist. Deficiencies other than general housekeeping issues are reported to the Nevada Division of Environmental Protection (NDEP) and remedied within 60 days of discovery.

\subsubsection{Inspection, Repair, and Maintenance Activities}

Semiannual inspections were performed on December 15, 2009, and June 23, 2010. During both inspections, the signs and fencing were in good condition, and there was no evidence of settling or cracking. No issues were identified, and no maintenance or repairs were required.

\subsection{Corrective Action Unit 91, Area 3 U-3Fi InJection Well}

\subsubsection{Permit Requirements}

Semiannual inspections are required at CAU 91 to evaluate the condition of the unit and identify deficiencies that may compromise the unit's integrity. Photographs are taken, and the results of the inspection are documented on a checklist. The permit does not specify a time limit for repairs or maintenance at CAU 91.

\subsubsection{Inspection, Repair, and Maintenance Activities}

Semiannual inspections were performed on March 17 and September 8, 2010. During the March inspection, the signs and fencing were in good condition, and there was no evidence of settling, animal burrowing, or vegetation on the cover. No issues were identified, and no maintenance or repairs were required. During the September inspection, vegetation was noted on the cover, and vegetation removal was recommended. Signs and fencing were in good condition, and there was no evidence of settling or animal burrowing. Vegetation removal activities were completed within 60 days and will be reported in the next annual report. No other issues were identified.

\subsection{Corrective Action Unit 92, Area 6 Decon Pond Facility}

\subsubsection{Permit Requirements}

Inspections are required quarterly at CAU 92 and in the event that precipitation occurs in excess of 0.50 inches (in.) in a 24-hour period. Inspections include an evaluation of the cover and identification of deficiencies that may compromise the unit's integrity. Photographs are taken, and the results of the inspection are documented on a checklist. The checklist documents the reason for the inspection (i.e., quarterly or excess precipitation) and any changes in the condition of the cover or fenced area, including, but not limited to, trash or debris within the fenced area, erosion of the cover, vegetation growing on the cover, and animal burrows or nesting activity. 
The condition of the fencing, wave barrier (fiberglass slats laced through the bottom of the chain-link fencing), use restriction warning signs, entrance gate, and lock is also documented. Small cracks or settling imperfections (less than 2 in. deep) on the cover are documented, and repairs are scheduled on an annual basis. Larger disruptions of the cover are immediately reported to NDEP and remedied within 60 days of discovery.

\subsubsection{Inspection, Repair, and Maintenance Activities}

Quarterly inspections were performed on December 15, 2009, and on March 17, June 23, and September 8, 2010. During the September 2009 inspection, vegetation was noted on the perimeter of the cover. Vegetation removal activities were completed on November 18, 2009. During the December inspection, standing water was noted outside the north and southeast edges of the cover, but no standing water was observed on the cover. Damage to the wave barrier was noted, and repair was recommended. The signs and fencing were in good condition, and no evidence of settling, cracking, or vegetation was observed on the cover. No other issues were identified. Wave barrier repair activities were completed on February 1, 2010.

On January 17-21, 2010, 2.62 in. of precipitation were recorded, and an inspection was conducted on January 25, 2010. During the inspection, standing water was noted outside the north, south, and southwest edges of the cover, but no standing water was observed on the cover. The signs, fencing, and wave barriers were in good condition, and no evidence of settling, cracking, or vegetation was observed on the cover. No issues were identified, and no maintenance or repairs were required.

During the March inspection, standing water was noted outside the north and southwest edges of the cover, but no standing water was observed on the cover. The signs, fencing, and wave barriers were in good condition, and no evidence of settling, cracking, or vegetation was observed on the cover. No issues were identified, and no maintenance or repairs were required.

During the June inspection, it was noted that the fence required repair. Damage to the wave barrier was noted, and repair was recommended. Vegetation was observed on the cover, and vegetation removal was recommended. The signs were in good condition, and no evidence of settling or cracking was observed. No other issues were identified. Fence and wave barrier repair and vegetation removal activities were completed on August 5, 2010.

During the September inspection, the signs, fencing, and wave barriers were in good condition, and no evidence of settling or cracking was observed. Vegetation was noted on the cover, and vegetation removal was recommended. Vegetation removal activities were completed within 60 days and will be reported in the next annual report. No other issues were identified.

\subsection{Corrective Action Unit 110, Area 3 WMD U-3AX/Bl Crater}

\subsubsection{Permit Requirements}

Quarterly inspections are required at CAU 110 to verify that the cover is intact. Photographs are taken, and the results of the inspection are documented on a checklist. The perimeter of the site is walked by the inspector, and the condition of the fencing and chicken wire, use restriction warning signs, and entrance gate and lock is documented. In addition, the seven subsidence markers (SMs) are inspected, and any changes in the condition of the cover, including, but not limited to, trash or debris within the fenced area, erosion of the cover, and animal burrows or nesting activity, are documented. Non-critical cracks or settling imperfections (equal to or less 
than 6 in. deep) on the cover are documented, and repairs are scheduled on an annual basis. Cracks or settling imperfections greater than 6 in. deep that extend 3 feet (ft) or more are reported to NDEP and repaired within 60 days of discovery.

\subsubsection{Inspection, Repair, and Maintenance Activities}

Quarterly inspections were performed on December 15, 2009, and on March 17, June 23, and September 8, 2010. During the September 2009 inspection, one sign was down that was required to be re-hung. The sign was re-hung on November 18, 2009. During the December inspection, animal burrows, evidence of settling, and subsidence cracks greater than 6 in. deep that extended 3-8 ft were observed. The signs and fencing were in good condition, and the vegetation appeared to be in good condition. No other issues were identified. Backfilling of animal burrows and subsidence repair activities were completed on January 28, 2010.

During the March inspection, the signs and fencing were in good condition, and no evidence of significant animal burrowing was observed on the cover. No evidence of settling or cracking was observed. The vegetation appeared to be in good condition. Vegetation had been reseeded on the east portion of the cover in February 2010, and the new vegetation was protected with temporary fencing. No issues were identified, and no maintenance or repairs were required.

During the June inspection, the signs and fencing were in good condition, and no evidence of significant animal burrowing was observed on the cover. No evidence of settling or cracking was observed. The vegetation appeared to be in good condition. No issues were identified, and no maintenance or repairs were required. As a best management practice, the outer perimeter snow fence was recommended for repair.

During the September inspection, the fencing was in good condition, and no evidence of significant animal burrowing was observed on the cover. No evidence of settling or cracking was observed. The vegetation appeared to be in good condition. Radiological warning signs were noted to be loose, and repair was recommended. Sign maintenance were completed within 60 days and will be reported in the next annual report. No other issues were identified.

\subsection{Corrective ACtion Unit 112, Area 23 Hazardous Waste Trenches}

\subsubsection{Permit Requirements}

Quarterly inspections are required at CAU 112 to evaluate the condition of the unit and identify deficiencies that may compromise the unit's integrity. The results of the inspection are documented on a checklist. The permit does not specify a time limit for repairs or maintenance at CAU 112.

\subsubsection{Inspection, Repair, and Maintenance Activities}

Quarterly inspections were performed on December 15, 2009, and on March 17, June 23, and September 8, 2010. During the December inspection, the signs and fencing were in good condition, and no evidence of settling, cracking, or animal burrowing was observed. Vegetation was observed on the cover, and vegetation removal was recommended. No other issues were identified. Vegetation removal activities were completed on January 28, 2010.

During the March inspection, the signs and fencing were in good condition, and no evidence of settling, cracking, or animal burrowing was observed. A minor amount of vegetation was 
observed that did not require follow-up actions. No issues were identified, and no maintenance or repairs were required.

During the June inspection, the signs and fencing were in good condition, and no evidence of settling, cracking, or animal burrowing was observed. Vegetation was observed on the cover, and vegetation removal was recommended. No other issues were identified. Vegetation removal activities were completed on August 3, 2010.

During the September inspection, the signs and fencing were in good condition, and no evidence of settling, cracking, vegetation, or animal burrowing was observed. No issues were identified, and no maintenance or repairs were required. 


\subsection{CORRECTIVE ACTION UNIT 110 SUBSIDENCE AND VEGETATION SURVEY RESULTS}

\subsection{SUBSIDENCE SURVEY}

Seven SMs are installed on the cover of CAU 110 to determine if subsidence of the cover is occurring. The initial baseline subsidence survey was conducted on December 14, 2000. Subsequent surveys are conducted twice per year and are compared to the December 2000 baseline survey results. Subsidence surveys were completed on March 24 and September 8, 2010.

The subsidence survey results are tabulated in Table 1. No significant subsidence was observed. SM \#5 shows the greatest decrease in elevation $(-0.10 \mathrm{ft})$ compared to the baseline survey in 2000. Calculated subsidence values are negligible and near the resolution of the survey instruments. This indicates that subsidence is not occurring on the cover.

\subsection{VEGETATION SURVEY}

The CAU 110 cover was initially planted with native seed in December 2000. Surveys have been conducted annually to assess the success of the revegetation effort. The vegetation survey was completed on May 17, 2010. The plant community on the cover is characterized by a combination of native perennial shrubs and annual forbs. Weedy species are occasionally present but make up a small percentage of total plant cover. Even though plant cover and density have declined from 5 years ago, a viable perennial plant community persists. There does not appear to be a need for remedial revegetation. The perennial grasses may re-establish on the closure cover with favorable growing conditions. 
RCRA Post-Closure Report

Date: January 2011

Table 1. Corrective Action Unit 110 Subsidence Survey Results

\begin{tabular}{|c|c|c|c|c|c|c|c|}
\hline \multirow{3}{*}{ DATE } & SM \#1 & SM \#2 & SM \#3 & SM \#4 & SM \#5 & SM \#6 & SM \#7 \\
\hline & \multicolumn{7}{|c|}{ Elevation at Top of Subsidence Marker ${ }^{1}$} \\
\hline & \multicolumn{7}{|c|}{ Subsidence Since December 2000 Baseline Survey (ft) } \\
\hline \multirow{2}{*}{$\begin{array}{c}\text { December } 2000 \\
\text { Baseline }\end{array}$} & $4,021.84$ & $4,021.28$ & $4,019.83$ & $4,020.99$ & $4,021.87$ & $4,019.25$ & $4,020.52$ \\
\hline & - & - & - & - & - & - & - \\
\hline \multirow{2}{*}{ July 2001} & $4,021.83$ & $4,021.28$ & $4,019.83$ & $4,020.98$ & $4,021.86$ & $4,019.24$ & $4,020.51$ \\
\hline & -0.01 & 0.00 & 0.00 & -0.01 & -0.01 & -0.01 & -0.01 \\
\hline \multirow{2}{*}{ January 2002} & $4,021.84$ & $4,021.28$ & $4,019.83$ & $4,020.98$ & $4,021.86$ & $4,019.24$ & $4,020.51$ \\
\hline & 0.00 & 0.00 & 0.00 & -0.01 & -0.01 & -0.01 & -0.01 \\
\hline \multirow{2}{*}{ September 2002} & $4,021.83$ & $4,021.27$ & $4,019.83$ & $4,020.98$ & $4,021.86$ & $4,019.24$ & $4,020.50$ \\
\hline & -0.01 & -0.01 & 0.00 & -0.01 & -0.01 & -0.01 & -0.02 \\
\hline \multirow{2}{*}{ January 2003} & $4,021.83$ & $4,021.27$ & $4,019.83$ & $4,020.98$ & $4,021.86$ & $4,019.24$ & $4,020.50$ \\
\hline & -0.01 & -0.01 & 0.00 & -0.01 & -0.01 & -0.01 & -0.02 \\
\hline \multirow{2}{*}{ July 2003} & $4,021.83$ & $4,021.27$ & $4,019.83$ & $4,020.97$ & $4,021.85$ & $4,019.24$ & $4,020.50$ \\
\hline & -0.01 & -0.01 & 0.00 & -0.02 & -0.02 & -0.01 & -0.02 \\
\hline \multirow{2}{*}{ March 2004} & $4,021.82$ & $4,021.26$ & $4,019.82$ & $4,020.97$ & $4,021.83$ & $4,019.22$ & $4,020.49$ \\
\hline & -0.02 & -0.02 & -0.01 & -0.02 & -0.04 & -0.03 & -0.03 \\
\hline \multirow{2}{*}{ September 2004} & $4,021.82$ & $4,021.26$ & $4,019.82$ & $4,020.96$ & $4,021.83$ & $4,019.23$ & $4,020.49$ \\
\hline & -0.02 & -0.02 & -0.01 & -0.03 & -0.04 & -0.02 & -0.03 \\
\hline \multirow{2}{*}{ March 2005} & $4,021.82$ & $4,021.26$ & 4,019.82 & $4,020.96$ & $4,021.82$ & 4,019.22 & $4,020.49$ \\
\hline & -0.02 & -0.02 & -0.01 & -0.03 & -0.05 & -0.03 & -0.03 \\
\hline \multirow{2}{*}{ September 2005} & $4,021.82$ & $4,021.26$ & 4,019.82 & $4,020.97$ & $4,021.82$ & $4,019.23$ & $4,020.49$ \\
\hline & -0.02 & -0.02 & -0.01 & -0.02 & -0.05 & -0.02 & -0.03 \\
\hline
\end{tabular}


TABle 1. Corrective Action Unit 110 Subsidence Survey Results, Continued

\begin{tabular}{|c|c|c|c|c|c|c|c|}
\hline \multirow{3}{*}{ DATE } & SM \#1 & SM \#2 & SM \#3 & SM \#4 & SM \#5 & SM \#6 & SM \#7 \\
\hline & \multicolumn{7}{|c|}{ Elevation at Top of Subsidence Marker ${ }^{1}$} \\
\hline & \multicolumn{7}{|c|}{ Subsidence Since December 2000 Baseline Survey (ft) } \\
\hline \multirow{2}{*}{ March 2006} & $4,021.82$ & $4,021.26$ & $4,019.82$ & $4,020.96$ & $4,021.82$ & $4,019.23$ & $4,020.49$ \\
\hline & -0.02 & -0.02 & -0.01 & -0.03 & -0.05 & -0.02 & -0.03 \\
\hline \multirow{2}{*}{ September 2006} & $4,021.82$ & $4,021.25$ & $4,019.82$ & $4,020.96$ & $4,021.81$ & $4,019.22$ & $4,020.49$ \\
\hline & -0.02 & -0.03 & -0.01 & -0.03 & -0.06 & -0.03 & -0.03 \\
\hline \multirow{2}{*}{ March 2007} & $4,021.82$ & $4,021.25$ & $4,019.82$ & $4,020.96$ & $4,021.80$ & $4,019.22$ & $4,020.48$ \\
\hline & -0.02 & -0.03 & -0.01 & -0.03 & -0.07 & -0.03 & -0.04 \\
\hline \multirow{2}{*}{ September 2007} & $4,021.81$ & $4,021.25$ & $4,019.81$ & $4,020.96$ & $4,021.79$ & $4,019.22$ & $4,020.49$ \\
\hline & -0.03 & -0.03 & -0.02 & -0.03 & -0.08 & -0.03 & -0.03 \\
\hline \multirow{2}{*}{ March 2008} & $4,021.81$ & $4,021.25$ & $4,019.81$ & $4,020.95$ & $4,021.79$ & $4,019.22$ & $4,020.48$ \\
\hline & -0.03 & -0.03 & -0.02 & -0.04 & -0.08 & -0.03 & -0.04 \\
\hline \multirow{2}{*}{ September 2008} & $4,021.81$ & $4,021.25$ & $4,019.81$ & $4,020.95$ & $4,021.78$ & $4,019.21$ & $4,020.48$ \\
\hline & -0.03 & -0.03 & -0.02 & -0.04 & -0.09 & -0.04 & -0.04 \\
\hline \multirow{2}{*}{ March 2009} & $4,021.81$ & $4,021.24$ & $4,019.81$ & $4,020.95$ & $4,021.78$ & $4,019.21$ & $4,020.48$ \\
\hline & -0.03 & -0.04 & -0.02 & -0.04 & -0.09 & -0.04 & -0.04 \\
\hline \multirow{2}{*}{ September 2009} & $4,021.81$ & $4,021.24$ & $4,019.80$ & $4,020.95$ & $4,021.77$ & $4,019.22$ & $4,020.48$ \\
\hline & -0.03 & -0.04 & -0.03 & -0.04 & -0.10 & -0.03 & -0.04 \\
\hline \multirow{2}{*}{ March 2010} & $4,021.81$ & $4,021.24$ & $4,019.80$ & 4,020.95 & $4,021.77$ & $4,019.21$ & $4,020.48$ \\
\hline & -0.03 & -0.04 & -0.03 & -0.04 & -0.10 & -0.04 & -0.04 \\
\hline \multirow{2}{*}{ September 2010} & $4,021.81$ & $4,021.24$ & $4,019.80$ & 4,020.95 & $4,021.77$ & $4,019.21$ & $4,020.48$ \\
\hline & -0.03 & -0.04 & -0.03 & -0.04 & -0.10 & -0.04 & -0.04 \\
\hline
\end{tabular}

\footnotetext{
${ }^{1}$ Elevations based on North American Vertical Datum of 1929 in ft.
} 
RCRA Post-Closure Report

Revision: 0

Date: January 2011

THIS PAGE INTENTIONALLY LEFT BLANK 


\subsection{CORRECTIVE ACTION UNIT 110 SOIL MOISTURE MONITORING RESULTS}

The CAU 110 cover is designed to prevent infiltration into the disposal unit. The cover performance is monitored using Time Domain Reflectometry (TDR) soil water content sensors buried within the waste cover. The TDR probes are buried at depths of 1 to $8 \mathrm{ft}$ below ground surface at 1-ft intervals. The TDR probes are installed at a distance of $165 \mathrm{ft}$ from the edge of the cover. Arrays of eight probes are positioned at four locations across the cover. Figure 2 illustrates the locations of TDR probes on the cover. Moisture content data from the TDR probes are recorded on a daily basis and stored on a data logger. The data are transmitted via radio frequency and downloaded on a quarterly basis.

Precipitation data were collected from meteorological station Buster Jangle Y, located approximately 3 miles northwest of CAU 110. The precipitation data are presented in Figure 3. Graphs of the TDR-derived soil moisture content profiles, combined with the daily precipitation values, are presented in Figures 4 through 7.

Soil moisture results obtained to date indicate that the CAU 110 cover is functioning as designed. Shallow soil moisture content is variable and dependent on precipitation events and the ability of shallow root systems and evapotranspiration to remove moisture from the soil. The ability for these systems to remove moisture can be locally inhibited if animal burrowing and grazing on plants affects the root systems; therefore, small mammals are being trapped and relocated from the cover to limit this damage.

Soil moisture contents for the TDR nests at depth are generally between 9 and 15 percent volumetric moisture content, depending on the location of the nest. Some locations show greater annual variability in moisture content; however, each location appears to have equilibrated to a consistent state for that location.

In the post-closure report for fiscal year 2009, the following compliance criterion was proposed and accepted by NDEP:

- The averaged water content of the three deepest TDR probes (6 ft, $7 \mathrm{ft}$, and $8 \mathrm{ft}$ ) is greater than 32 percent volumetric moisture content for a continuous 6-month period.

Using conservative assumptions for the soil properties, 32 percent volumetric moisture content equates to 80 percent saturation of the soil. If the average volumetric moisture content of the three deepest TDR probes $(6 \mathrm{ft}, 7 \mathrm{ft}$, and $8 \mathrm{ft}$ ) exceeds 32 percent for a continuous 6 -month period, the compliance criterion has been exceeded. If this occurs, NDEP will be notified, and a path forward will be proposed.

The action level is illustrated on Figures 4 through 7. The action level was not exceeded. 


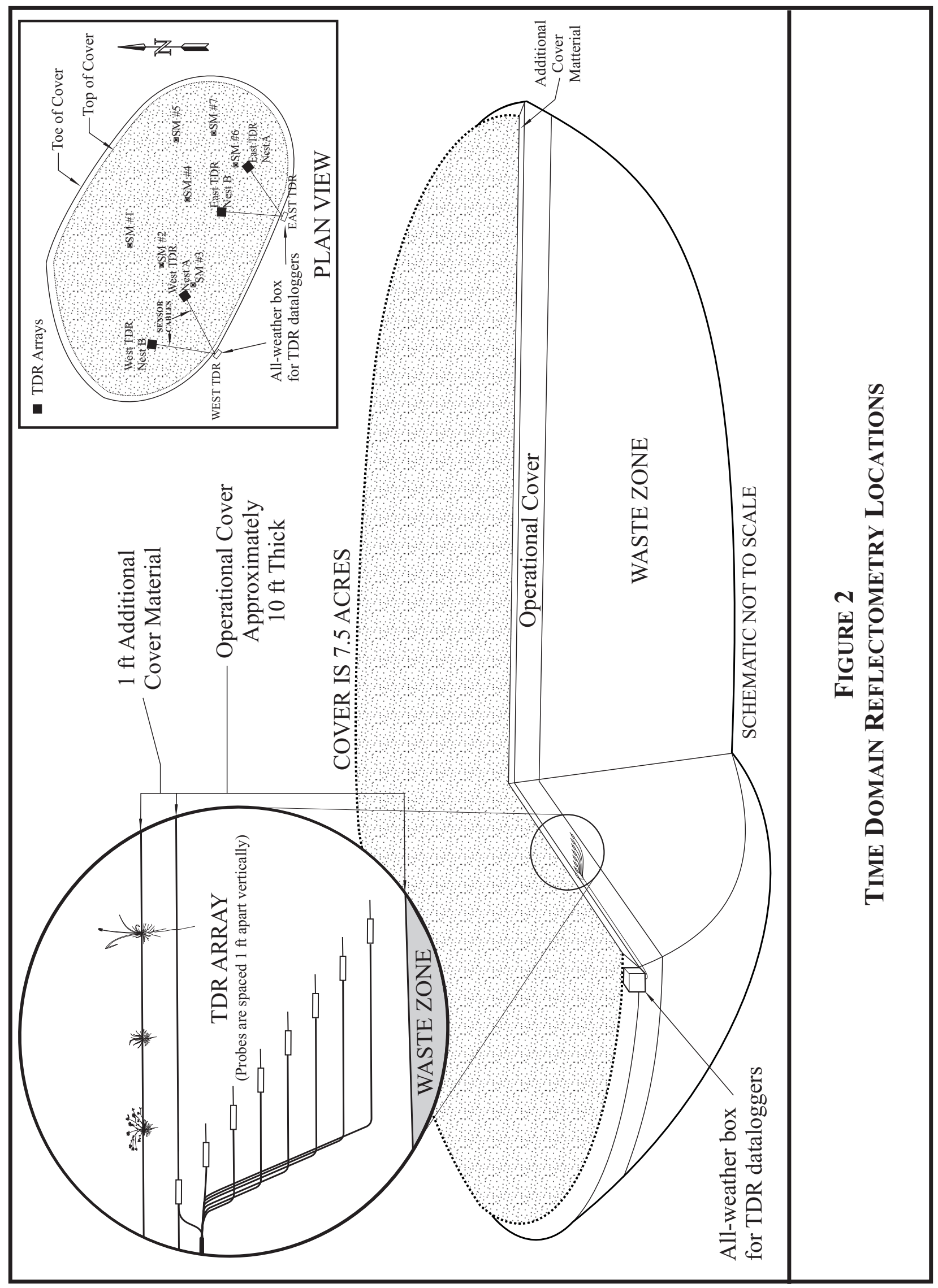




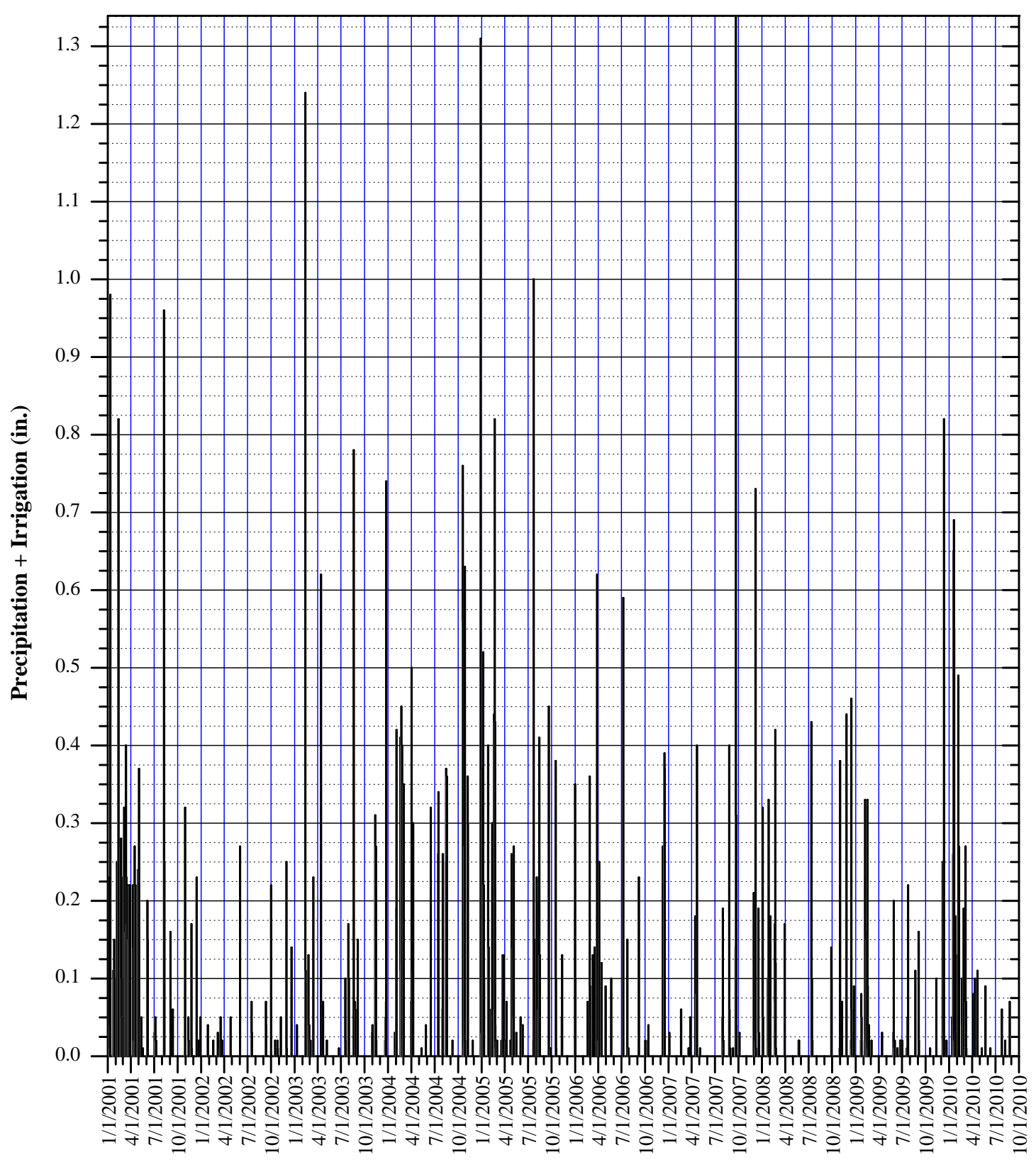

Date

FIGURE 3

PRECIPITATION DATA FOR METEOROLOGICAL STATION BUSTER JANGLE Y 


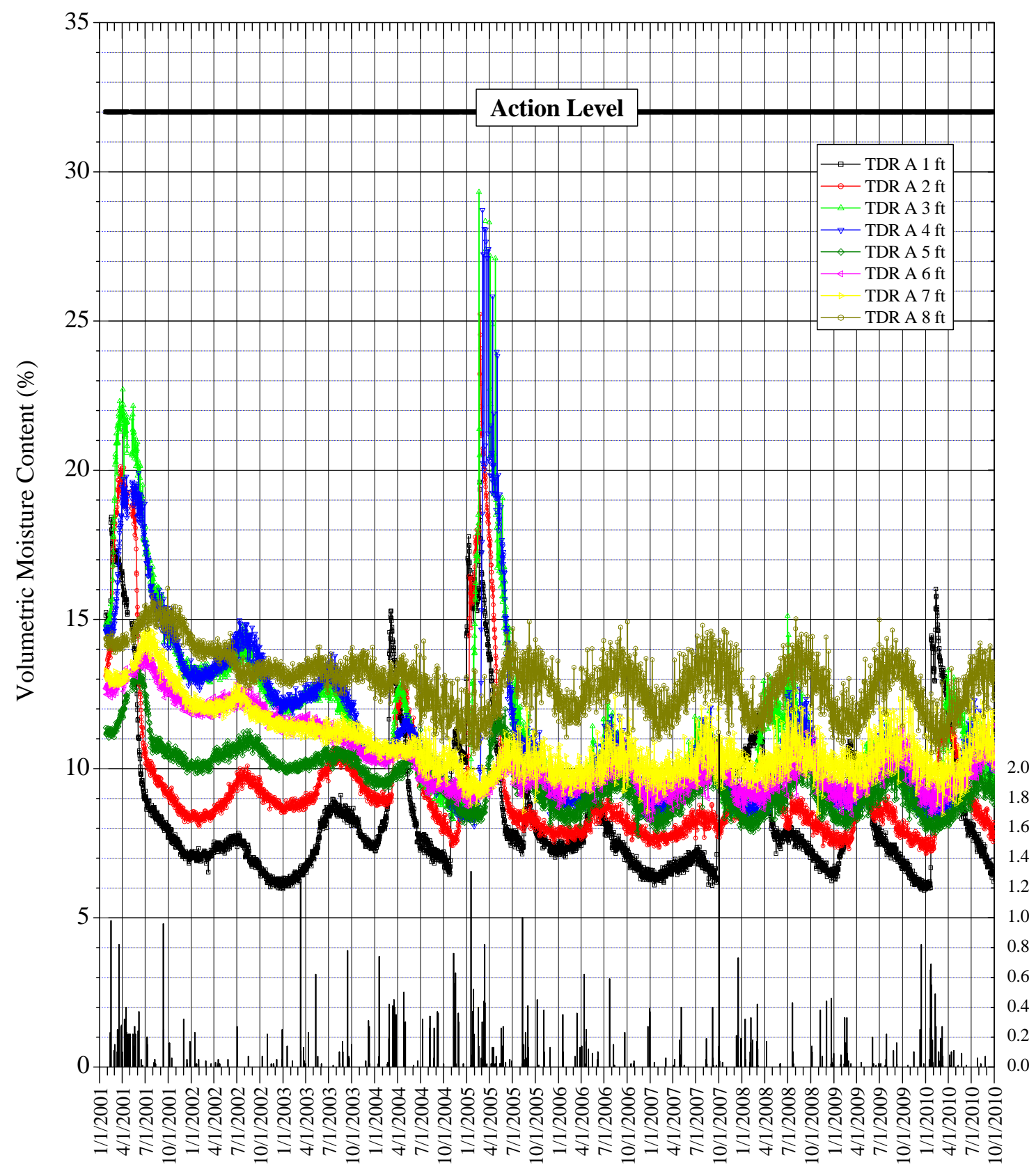

Day of Year

FIGURE 4

EAst TDR Nest A SoIL Moisture Content ProfiLe 




Day of Year

FIGURE 5

EAST TDR Nest B SoIL MOISTURe ConTent PROFILE 


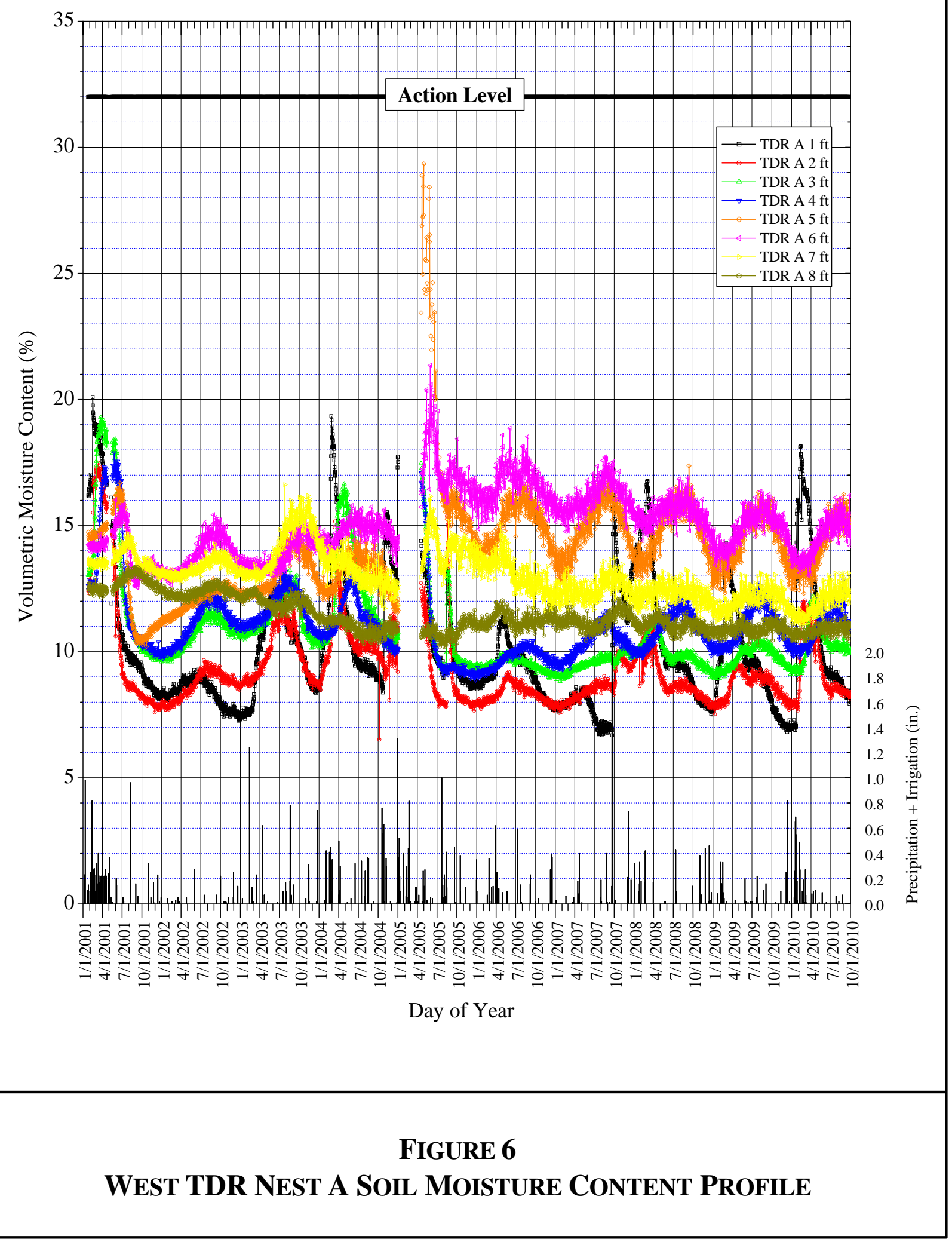




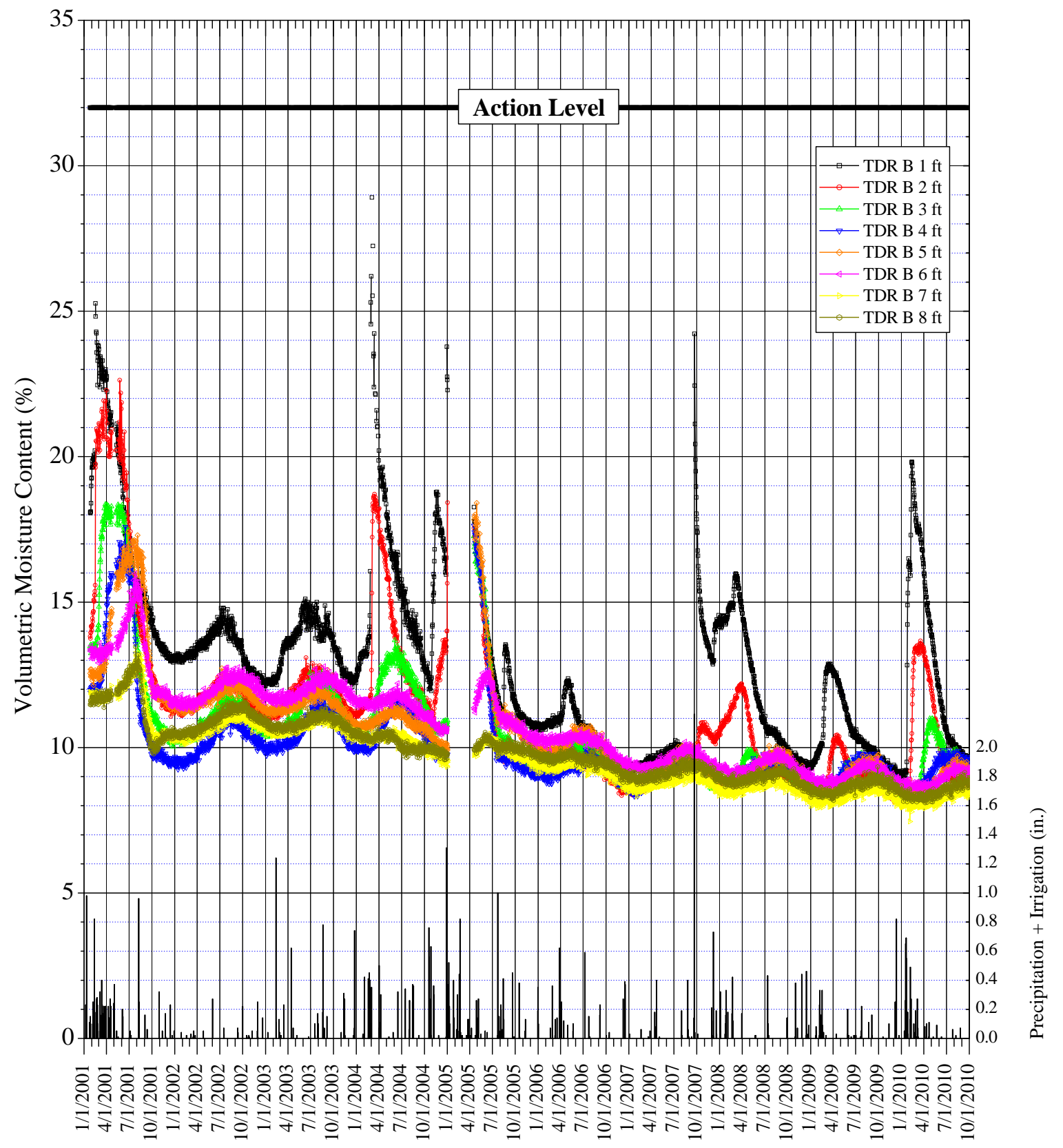

Day of Year

FIGURE 7

West TDR Nest B SoIL MoIsture ConTent PRofiLe 
RCRA Post-Closure Report

Revision: 0

Date: January 2011

THIS PAGE INTENTIONALLY LEFT BLANK 


\subsection{CONCLUSIONS AND RECOMMENDATIONS}

\subsection{Corrective ACtion Unit 90, AREA 2 Bitcutter ContainMent}

Semiannual inspections were performed on December 15, 2009, and June 23, 2010. During the last inspection, no maintenance or repairs were required. It is recommended to continue semiannual inspections.

\subsection{Corrective Action Unit 91, Area 3 U-3Fi InJection Well}

Semiannual inspections were performed on March 17 and September 8, 2010. During the last inspection, vegetation was noted on the cover. Vegetation removal activities will be completed within 60 days and reported in the next annual report. No additional maintenance or repairs were required. It is recommended to continue semiannual inspections.

\subsection{Corrective Action Unit 92, Area 6 Decon Pond Facility}

Quarterly inspections were performed on December 15, 2009, and on March 17, June 23, and September 8, 2010. An inspection was performed on January 25, 2010, after a precipitation event in excess of 0.50 in. occurred. During the last inspection, vegetation was noted on the cover. Vegetation removal activities will be completed within 60 days and reported in the next annual report. No additional maintenance or repairs were required. It is recommended to continue quarterly inspections.

\subsection{Corrective Action Unit 110, Area 3 WMD U-3AX/Bl Crater}

Quarterly inspections were performed on December 15, 2009, and on March 17, June 23, and September 8, 2010. During the last inspection, radiological warning signs were noted to be loose. Sign maintenance will be completed within 60 days and reported in the next annual report. No additional maintenance or repairs were required.

Subsidence survey results indicate that no significant subsidence of the cover is occurring. Soil moisture results obtained to date indicate that the cover is functioning as designed, and the action level was not exceeded.

The following actions are recommended for CAU 110:

- Continue quarterly inspections

- Continue semiannual subsidence surveys

- Continue to annually monitor the vegetation

\subsection{Corrective Action Unit 112, Area 23 Hazardous Waste Trenches}

Quarterly inspections were performed on December 15, 2009, and on March 17, June 23, and September 8, 2010. During the last inspection, no maintenance or repairs were required. It is recommended to continue quarterly inspections. 
RCRA Post-Closure Report

Revision: 0

Date: January 2011

THIS PAGE INTENTIONALLY LEFT BLANK 
RCRA Post-Closure Report

Revision: 0

Date: January 2011

\section{Appendix A.}

\section{INSPECTION CHECKLISTS}


RCRA Post-Closure Report

Revision: 0

Date: January 2011

\section{THIS PAGE INTENTIONALLY LEFT BLANK}


RCRA Post-Closure Report

Revision: 0

Date: January 2011

CORRECTIVE ACTION UNIT 90 INSPECTION CHECKLISTS 
RCRA Post-Closure Report

Revision: 0

Date: January 2011

\section{THIS PAGE INTENTIONALLY LEFT BLANK}




\section{POST-CLOSURE INSPECTION CHECKLIST}

\section{CAU 90: AREA 2 BITCUTTER CONTAINMENT - CAS 02-20-01: Bitcutter/PS Inj. Wells (3) (RCRA)}

\begin{tabular}{|c|c|c|c|}
\hline Inspection Date and Time: & $9: 40 \mathrm{AM}$ & Reason for Inspection: & Semi-Annual \\
\hline Date of Last Post-Closure Inspection: & 09 & Reason for Last Post-C & sure Inspection: Semi-Annual \\
\hline \multicolumn{4}{|c|}{ Responsible Entity: NSTec Environmental Restoration, Nevada Test Site, Mercury, Nevada } \\
\hline \multicolumn{4}{|c|}{ Responsible Facility Owner: Thomas A. Thiele, Project Manager, Industrial Sites, Environmental Restoration Project } \\
\hline Chief Inspector: Glenn Richardson & Title: Task & nager & Organization: Environmental Restoration \\
\hline Assistant Inspector: Greq Doyle & Title: Sr. Scie & fist & Organization: Environmental Restoration \\
\hline
\end{tabular}

A. GENERAL INSTRUCTIONS

- Complete all checklist items.

- If a SHADED BOX is checked, provide detailed information regarding what was found and/or appropriate references to other documents that have the information (e.g., Maintenance Order Form for CAU 90 dated 2/15/2008).

- All documentation must be legible and clear.

\begin{tabular}{|c|c|c|c|}
\hline B. PREPARATION (To be competed prior to site visit) & YES & NO & EXPLANATION (required if shaded box is checked) \\
\hline \multicolumn{4}{|l|}{ 1. Has the Post-Closure Permit been reviewed? } \\
\hline \multicolumn{4}{|l|}{ 2. Has the Post-Closure Permit application been reviewed? } \\
\hline \multicolumn{4}{|l|}{ 3. Has the Post-Closure Plan been reviewed? } \\
\hline \multicolumn{4}{|l|}{ 4. Have the site as-built plans and site base map been reviewed? } \\
\hline \multicolumn{4}{|l|}{ 5. Have the previous inspection reports been reviewed? } \\
\hline \multicolumn{4}{|l|}{ a. Were anomalies or trends detected on previous inspections? } \\
\hline b. Was maintenance performed? & & & \\
\hline \multicolumn{4}{|l|}{ 6. Have the site maintenance and repair records been reviewed? } \\
\hline $\begin{array}{l}\text { a. If so, has site repair resulted in a change from as-built } \\
\text { conditions? }\end{array}$ & & & NA \\
\hline $\begin{array}{l}\text { b. If yes (to } 6 a) \text {, are revised as-built plans available that reflect } \\
\text { repair changes? }\end{array}$ & & & NA \\
\hline
\end{tabular}

\section{SITE INSPECTION PREPARATION}

Assemble the following, as needed, to conduct inspections:
a. Camera, digital storage drive, and extra batteries
b. Keys to locks
c. Clipboard
d. Tape measure
e. Radio, pager, etc.
f. Previous Post-Closure Report, Inspection Checklists, repair records, and as-built plans
g. Other miscellaneous support equipment 


\section{POST-CLOSURE INSPECTION CHECKLIST}

\section{CAU 90: AREA 2 BITCUTTER CONTAINMENT - CAS 02-20-01: Bitcutter/PS Inj. Wells (3) (RCRA)}

D. SITE INSPECTION

- The site inspection is a walking inspection of the entire site including the perimeter and sufficient transects to be able to inspect the entire surface and all features specifically described in this checklist. The checklist should be completed during the site inspection.

- If a shaded box is checked, add detailed comments to document the results of the site inspection. Information provided should be of sufficient detail to enable reconstruction of observations regarding field conditions. Information can take the form of written narrative, sketches, measurements, and annotated site maps, all of which should be placed on additional attachments (if needed) and cross-reference appropriately. Attach the additional pages and number all pages upon completion of the inspection. The completed checklist is part of the field record of the inspection.

- Field notes taken to assist in completion of this checklist will become part of the inspection record. No form is specified for field notes, and additional field notes are not required if the checklist and associated attachments adequately describe site conditions.

1. Adjacent off-site features:

a. Are there any new activities or features in the vicinity that could potentially affect the site (e.g., activities that change the flow of surface water or are encroaching the unit)?

2. Fences, gates, and signs (East Fenced Enclosure):

a. Is there damage to or a break in the fence?

b. Have any fenceposts been damaged or their anchoring weakened?

c. Is the gate intact and functional?

d. Does the gate show evidence of tampering or damage?

e. Was the gate locked?

f. Are any of the use restriction signs damaged or missing?

g. Are all use restriction signs legible?

h. How many use restriction signs need to be replaced?

i. Other?

3. Waste unit cover (East Fenced Enclosure):

a. Is there evidence of settling?

b. Is there evidence of cracking?

c. Is there evidence of erosion (wind or water)?

d. Is there evidence of human intrusion onto the cover?

e. Is there evidence of large animal intrusion onto the cover?

f. Is there evidence of animal burrowing?

g. Is vegetation growing on the cover?

h. Other (including trash, debris, etc within fenced area)?

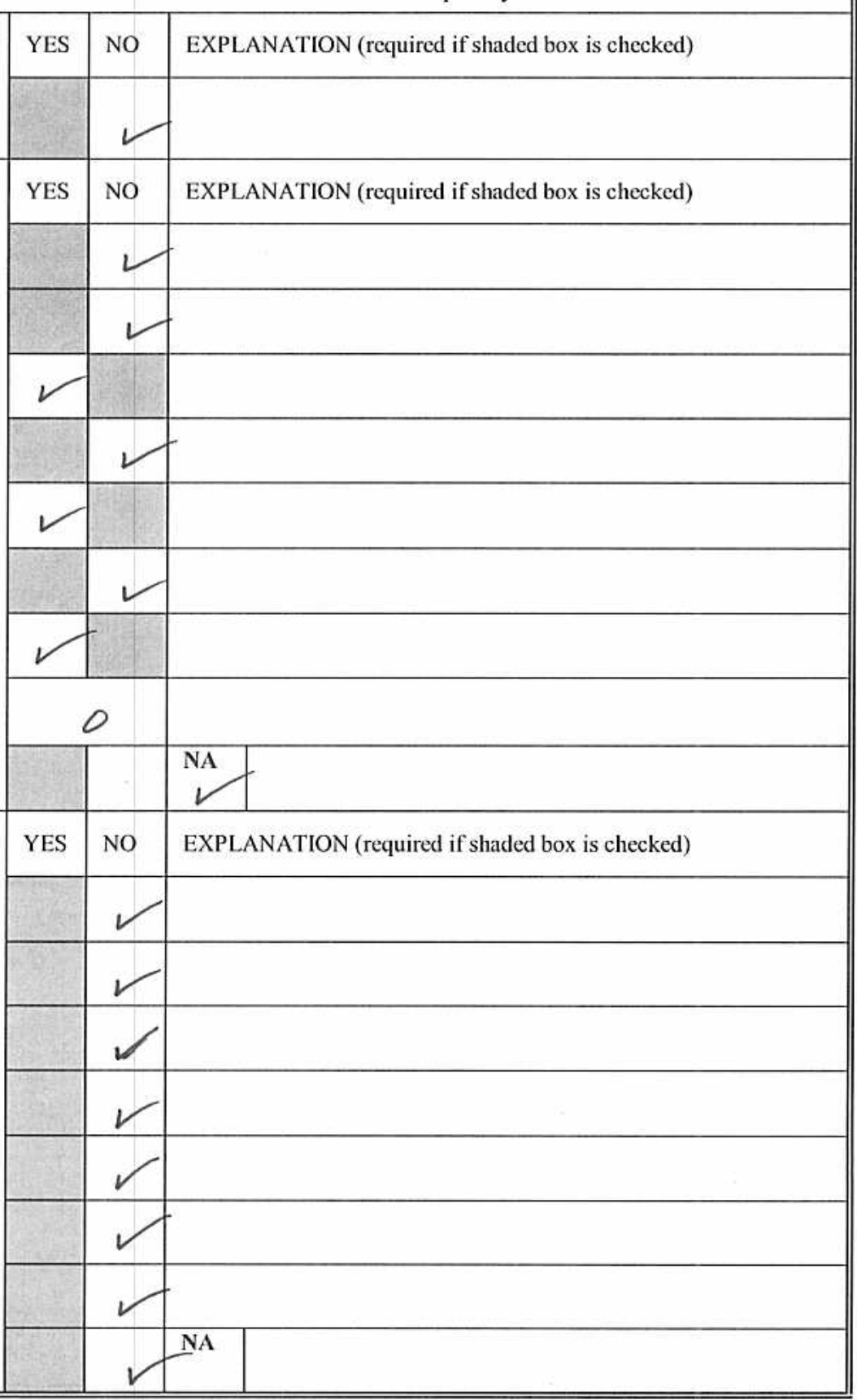




\section{POST-CLOSURE INSPECTION CHECKLIST}

\section{CAU 90: AREA 2 BITCUTTER CONTAINMENT - CAS 02-20-01: Bitcutter/PS Inj. Wells (3) (RCRA)}

4. Fences, gates, and signs (West Fenced Enclosure):

a. Is there damage to or a break in the fence?

b. Have any fenceposts been damaged or their anchoring weakened?

c. Is the gate intact and functional?

d. Does the gate show evidence of tampering or damage?

e. Was the gate locked?

f. Are any of the use restriction signs damaged or missing?

g. Are all use restriction signs legible?

h. How many use restriction signs need to be replaced?

i. Other?

5. Waste unit cover (West Fenced Enclosure):

a. Is there evidence of settling?

b. Is there evidence of cracking?

c. Is there evidence of erosion (wind or water)?

d. Is there evidence of human intrusion onto the cover?

e. Is there evidence of large animal intrusion onto the cover?

f. Is there evidence of animal burrowing?

g. Is vegetation growing on the cover?

h. Other (including trash, debris, etc within fenced area)?

\begin{tabular}{|c|c|c|}
\hline YES & NO & EXPLANATION (required if shaded box is checked) \\
\hline & & \\
\hline & & \\
\hline & & \\
\hline & & \\
\hline & & \\
\hline & & \\
\hline & & \\
\hline \multicolumn{2}{|c|}{0} & \\
\hline & & NA \\
\hline YES & NO & EXPLANATION (required if shaded box is checked) \\
\hline & & \\
\hline & 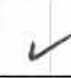 & \\
\hline & 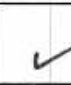 & \\
\hline & $v$ & \\
\hline & $\checkmark$ & \\
\hline & $\checkmark$ & \\
\hline & $\checkmark$ & \\
\hline & & \\
\hline
\end{tabular}

6. Photograph Instructions:

- A standard set of color photographs is required. Six photographs must be taken during each inspection of CAU 90:

- Three (3) of the west unit from outside the fence, one in each compass direction (i.e., N, S, E) and

- Three (3) of the east unit from outside the fence, one in each compass direction (i.e., N, S, W).

- In addition, all anomalous features or new features (such as changes in adjacent area land use) are to be photographed.

- Additional photographs may also be taken.

- A photograph log entry will be made for each photograph taken.

7. Photograph Documentation:

a. Have all photographs been taken as required by the photograph instructions?

b. Has a photograph log been prepared?

c. How many photographs were taken?

d. Other?

\begin{tabular}{|l|l|l||}
\hline YES & NO & EXPLANATION (required if shaded box is checked) \\
\hline & & \\
\hline & & \\
\hline 6 & & \\
\hline
\end{tabular}




\section{POST-CLOSURE INSPECTION CHECKLIST}

\section{CAU 90: AREA 2 BITCUTTER CONTAINMENT - CAS 02-20-01: Bitcutter/PS Inj. Wells (3) (RCRA)}

\begin{tabular}{||l|l|l|l|}
\hline \hline E. FIELD CONCLUSIONS & YES & NO & EXPLANATION (required if shaded box is checked) \\
\hline 1. Are more frequent inspections required? & & \\
\hline 2. Are previous maintenance/repair actions satisfactory? & $\begin{array}{c}\text { If "yes", describe below and the Task Manager must complete the } \\
\text { "Follow-up Actions" (not part of checklist) }\end{array}$ \\
\hline $\begin{array}{l}\text { 3. Are there any deficiencies that require a remedy other than } \\
\text { 4. Will necessary repairs change the as-built condition of the unit? }\end{array}$ & & $\begin{array}{c}\text { If "yes", describe below and the Task Manager must complete the } \\
\text { "Follow-up Actions" (not part of checklist) }\end{array}$ \\
\hline
\end{tabular}

5. Field conclusions/recommendations: The UR signs and fencing were in excellent condition. There was no evidence of intrusion or animal burrowing. Also, there was no evidence of new vegetation growth within the fenced area or around the concrete monument pad. There are no follow-up actions required at this site.

\section{F. CERTIFICATION}

I have conducted an inspection of CAU 90, Area 2 Bitcutter Containment, in accordance with the procedures of the Post-Closure Permit (including the Post-Closure Plan) as recorded on this checklist, attached sheets, tield notes, photographs, and photograph logs.

Chief Inspector's Signature/s/: Glenn Ríchardson Date:

Printed Name: Glenn Richardson

$12 / 15 / 09$

Required Attachments:

1. Field Notes (if any)

2. Photos (or note File Location: S:INTSLER Sharelphotos/CAU 901 2009) 12-15-2009 CAU 90 Inspection

Distribution: Original - Industrial Sites Project Manager

Copy - Task Manager

\section{G. VERIFICATION}

I have reviewed/Tis checklist and attachments and have verified that it is complete.

\section{signature: /s/: Reed Poderis}

Printed Name: Thomas A. Thiele (or designee)

Distribution: Original - Task Manager 


\section{POST-CLOSURE INSPECTION CHECKLIST}

\section{CAU 90: AREA 2 BITCUTTER CONTAINMENT - CAS 02-20-01: Bitcutter/PS Inj. Wells (3) (RCRA) CAS 02-20-03: Wastewater Pit}

\begin{tabular}{||l|l||}
\hline \hline Inspection Date and Time: $6 / 25 / 10 \quad 10: 15$ & Reason for Inspection: $5<m i$. \\
\hline Date of Last Post-Closure Inspection: $3 / 17 / 10$ & Reason for Last Post-Closure Inspection: Sea \\
\hline
\end{tabular}

Responsible Entity: NSTec Environmental Restoration, Nevada Test Site, Mercury, Nevada

Responsible Facility Owner: Thomas A. Thiele, Project Manager, Industrial Sites, Environmental Restoration Project

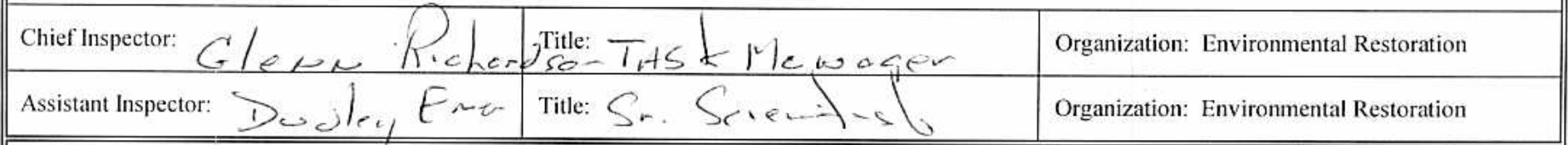

\section{A. GENERAL INSTRUCTIONS}

- Complete all checklist items.

- If a SHADED BOX is checked, provide detailed information regarding what was found and/or appropriate references to other documents that have the information (e.g., Maintenance Order Form for CAU 90 dated 2/15/2008).

- All documentation must be legible and clear.

\section{B. PREPARATION (To be competed prior to site visit)}

1. Has the Post-Closure Permit been reviewed?

2. Has the Post-Closure Permit application been reviewed?

3. Has the Post-Closure Plan been reviewed?

4. Have the site as-built plans and site base map been reviewed?

5. Have the previous inspection reports been reviewed?

a. Were anomalies or trends detected on previous inspections?

b. Was maintenance performed?

6. Have the site maintenance and repair records been reviewed?

a. If so, has site repair resulted in a change from as-built conditions?

b. If yes (to 6a), are revised as-built plans available that reflect repair changes?

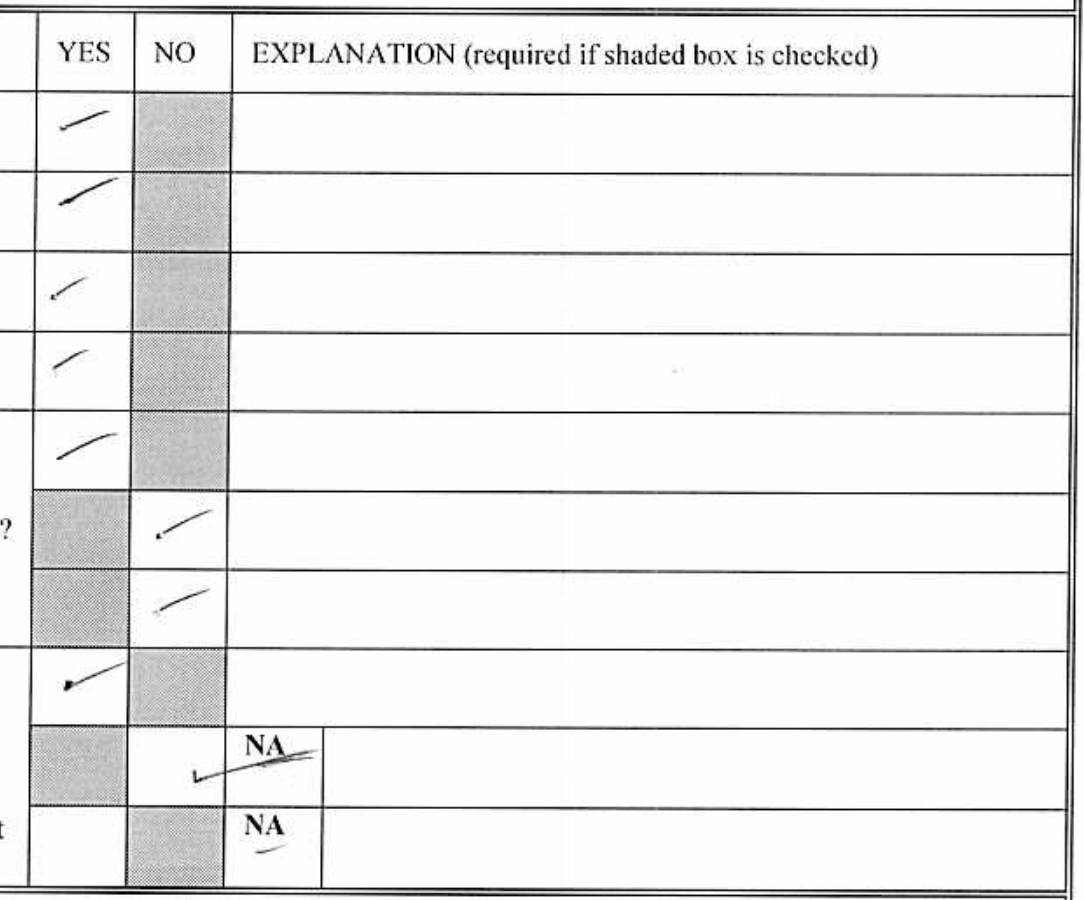

\section{SITE INSPECTION PREPARATION}

Assemble the following, as needed, to conduct inspections:

a. Camera, digital storage drive, and extra batteries

b. Keys to locks

c. Clipboard

d. Tape measure

e. Radio, pager, etc.

f. Previous Post-Closure Report, Inspection Checklists, repair records, and as-built plans

g. Other miscellaneous support equipment 


\begin{tabular}{|c|c|}
\hline \hline POST-CLOSURE INSPECTION CHECKLIST \\
\hline \hline CAU 90: AREA 2 BITCUTTER CONTAINMENT - CAS 02-20-01: Bitcutter/PS Inj. Wells (3) (RCRA) \\
CAS 02-20-03: Wastewater Pit \\
\hline \hline
\end{tabular}

\section{SITE INSPECTION}

- The site inspection is a walking inspection of the entire site including the perimeter and sufficient transects to be able to inspect the entire surface and all features specifically described in this checklist. The checklist should be completed during the site inspection.

- If a shaded box is checked, add detailed comments to document the results of the site inspection. Information provided should be of sufficient detail to enable reconstruction of observations regarding field conditions. Information can take the form of written narrative, sketches, measurements, and annotated site maps, all of which should be placed on additional attachments (if needed) and cross-reference appropriately. Attach the additional pages and number all pages upon completion of the inspection. The completed checklist is part of the field record of the inspection.

- Field notes taken to assist in completion of this checklist will become part of the inspection record. No form is specified for field notes, and additional field notes are not required if the checklist and associated attachments adequately describe site conditions.

1. Adjacent off-site features:

a. Are there any new activities or features in the vicinity that could potentially affect the site (e.g., activities that change the flow of surface water or are encroaching the unit)?

2. Fences, gates, and signs (East Fenced Enclosure):

a. Is there damage to or a break in the fence?

b. Have any fenceposts been damaged or their anchoring weakened?

c. Is the gate intact and functional?

d. Does the gate show evidence of tampering or damage?

e. Was the gate locked?

f. Are any of the use restriction signs damaged or missing?

g. Are all use restriction signs legible?

h. How many use restriction signs need to be replaced?

i. Other?

3. Waste unit cover (East Fenced Enclosure):

a. Is there evidence of settling?

b. Is there evidence of cracking?

c. Is there evidence of erosion (wind or water)?

d. Is there evidence of human intrusion onto the cover?

e. Is there evidence of large animal intrusion onto the cover?

f. Is there evidence of animal burrowing?

g. Is vegetation growing on the cover?

h. Other (including trash, debris, etc within fenced area)?

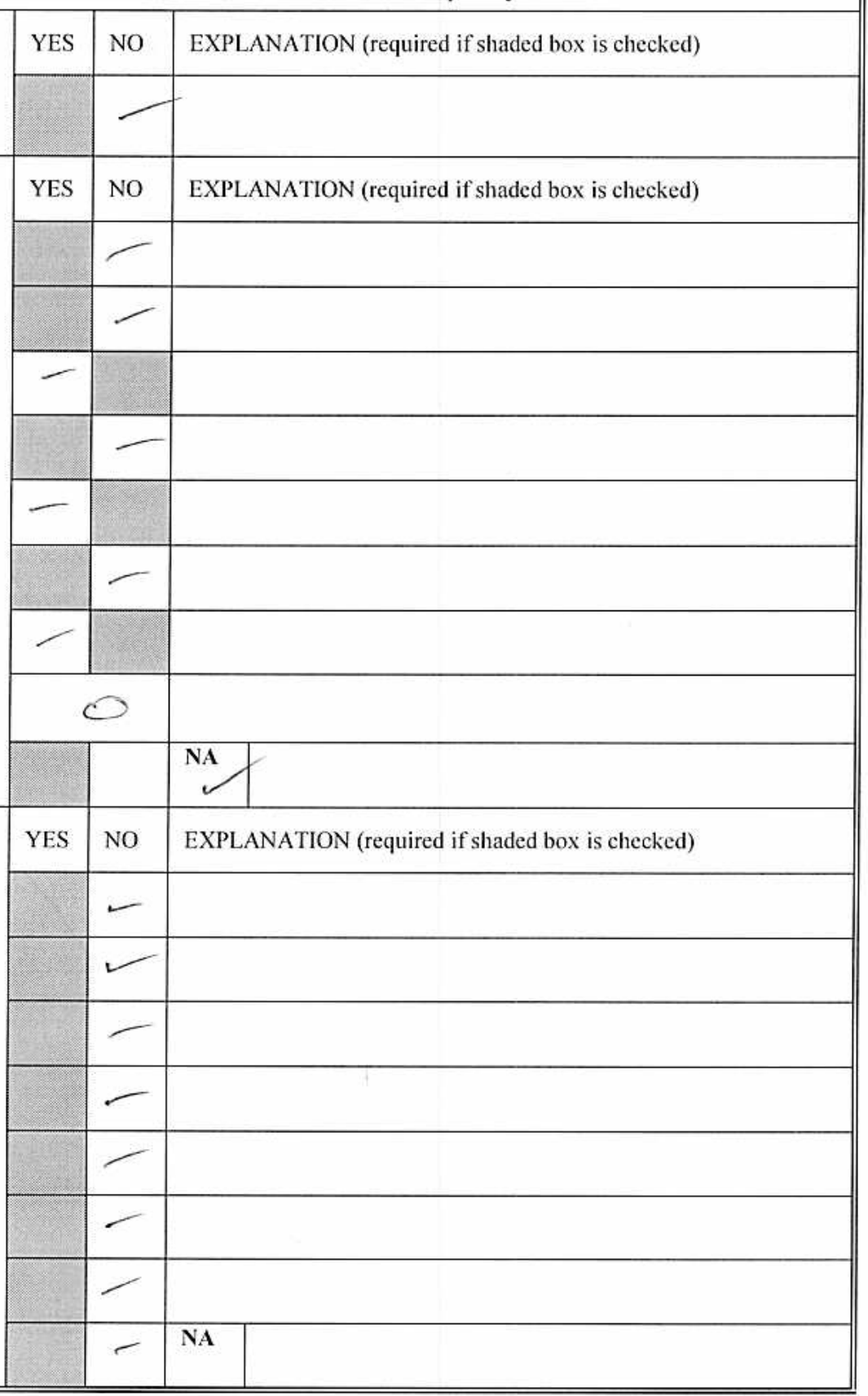


POST-CLOSURE INSPECTION CHECKLIST

\section{CAU 90: AREA 2 BITCUTTER CONTAINMENT - CAS 02-20-01: Bitcutter/PS Inj. Wells (3) (RCRA)} CAS 02-20-03: Wastewater Pit

4. Fences, gates, and signs (West Fenced Enclosure):

a. Is there damage to or a break in the fence?

b. Have any fenceposts been damaged or their anchoring weakened?

c. Is the gate intact and functional?

d. Does the gate show evidence of tampering or damage?

e. Was the gate locked?

f. Are any of the use restriction signs damaged or missing?

g. Are all use restriction signs legible?

h. How many use restriction signs need to be replaced?

i. Other?

5. Waste unit cover (West Fenced Enclosure);

a. Is there evidence of settling?

b. Is there evidence of cracking?

c. Is there evidence of erosion (wind or water)?

d. Is there evidence of human intrusion onto the cover?

e. Is there evidence of large animal intrusion onto the cover?

f. Is there evidence of animal burrowing?

g. Is vegetation growing on the cover?

h. Other (including trash, debris, etc within fenced area)?

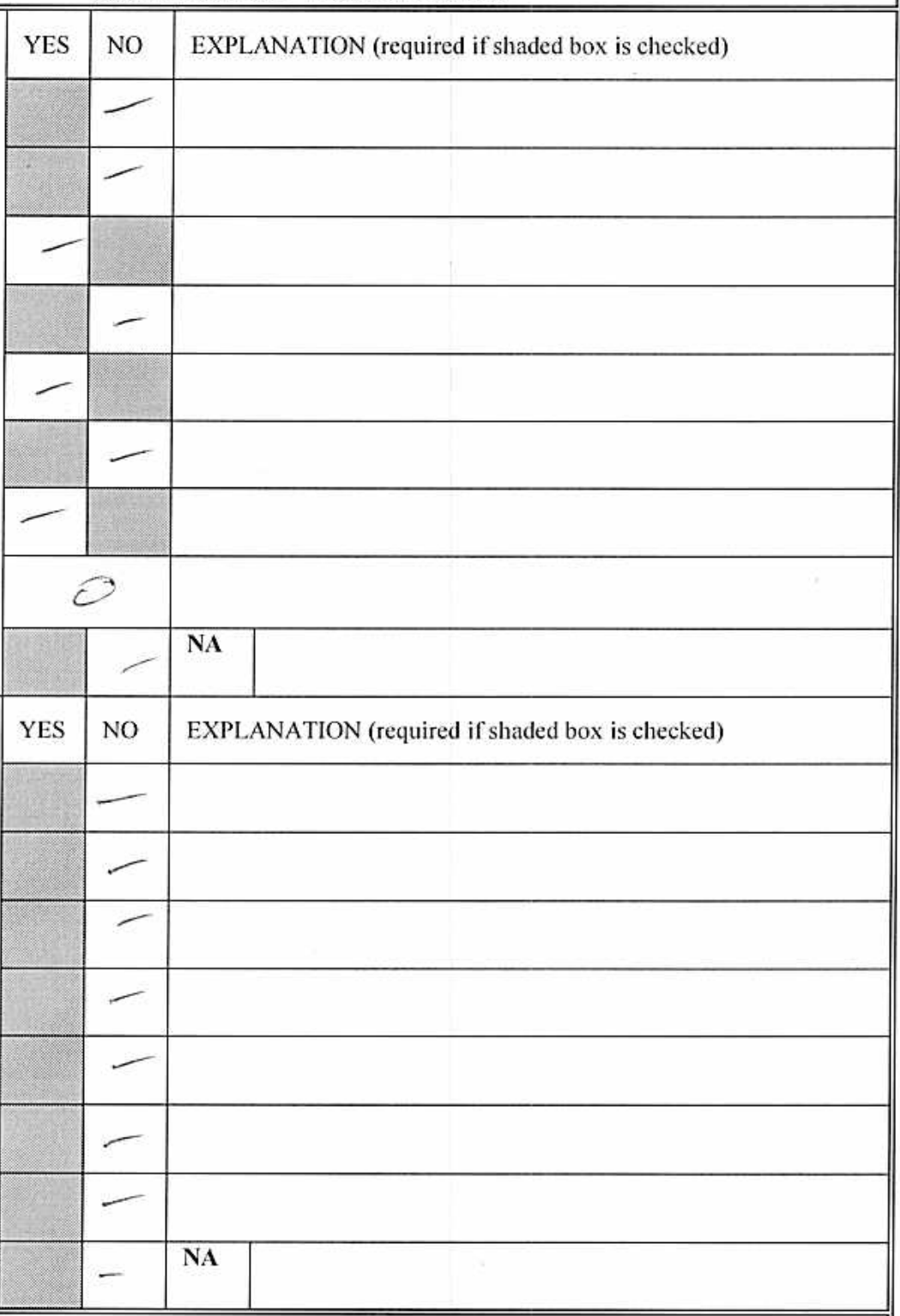

6. Photograph Instructions:

- A standard set of color photographs is required. Six photographs must be taken during each inspection of CAU 90:

- Three (3) of the west unit from outside the fence, one in each compass direction (i.e., N, S, E) and

- Three (3) of the east unit from outside the fence, one in each compass direction (i.e., N, S, W).

- In addition, all anomalous features or new features (such as changes in adjacent area land use) are to be photographed.

- Additional photographs may also be taken.

- A photograph log entry will be made for each photograph taken.

7. Photograph Documentation:

a. Have all photographs been taken as required by the photograph instructions?

b. Has a photograph log been prepared?

c. How many photographs were taken?

d. Other?

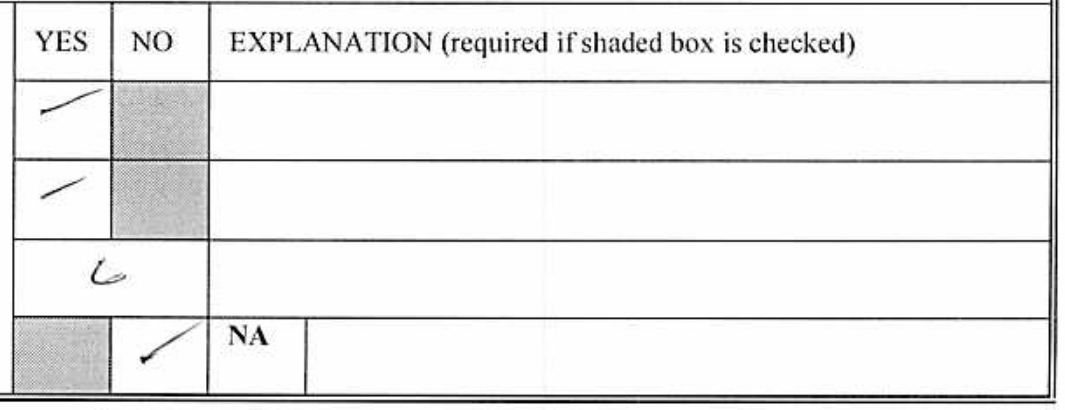

Page 3 of 4 


\section{POST-CLOSURE INSPECTION CHECKLIST}

\section{CAU 90: AREA 2 BITCUTTER CONTAINMENT - CAS 02-20-01: Bitcutter/PS Inj. Wells (3) (RCRA) CAS 02-20-03: Wastewater Pit}

\begin{tabular}{||l|l|l|l|l}
\hline \hline E. FIELD CONCLUSIONS & YES & NO & EXPLANATION (required if shaded box is checked) \\
\hline 1. Are more frequent inspections required? & & & & If "yes", describe below and the Task Manager must complete the \\
\hline 2. Are previous maintenance/repair actions satisfactory? & general housekeeping (i.e., "minor") repairs?
\end{tabular}

\section{F. CERTIFICATION}

Thave conducted an inspection of CAU 90, Area 2 Bitcutter Containment, in accordance with the procedures of the Post-Closure Permit (including the Post-Closure Plan) as recorded on this checklist, attached sheets, fietd notes, photographs, and photograph logs.

Chief Inspector's Signature/s/: Glenn Richardson Date: $6 / 23 / 10$

Printed Name: Glenn Richardson

Title:

Task Manager

Required Attachments:

1. Field Notes (if any)

2. Photos (or note File Location: S:INTSIER SharelPhotosl CAU 090 201016-23-2010 CA4 90 inspection

Distribution: Original - Industrial Sites Project Manager

Copy - Task Manager

\section{G. VERIFICATION}

I have reviewed $\mathrm{h}^{\text {his }}$ che $\mathrm{h}^{\mathrm{k}} \mathrm{kst}$ and attachments and have verified that it is complete.

Signature: /s/: Reed Poderis

Printed Name: Thomas A. Thlele (or designee)

Date: $7 / 26 / .0$

Distribution: Original - Task Manager 
RCRA Post-Closure Report

Revision: 0

Date: January 2011

CORRECTIVE ACTION UNIT 91 INSPECTION CHECKLISTS 
RCRA Post-Closure Report

Revision: 0

Date: January 2011

\section{THIS PAGE INTENTIONALLY LEFT BLANK}




\section{POST-CLOSURE INSPECTION CHECKLIST}

\begin{tabular}{|c|c|c|c|}
\hline \multicolumn{4}{|c|}{ CAU 91: AREA 3 U-3fi INJECTION WELL - CAS 03-20-03: UD-6 and UD-6s Disposal Holes } \\
\hline Inspection Date and Time: & $10: 25 \mathrm{AM}$ & Reason for & Semi-Annual \\
\hline \multicolumn{2}{|c|}{ Date of Last Post-Closure Inspection: $\quad 9 / 23 / 09$} & \multicolumn{2}{|c|}{ Reason for Last Post-Closure Inspection: Semi-Annual } \\
\hline \multicolumn{4}{|c|}{ Responsible Entity: NSTec Environmental Restoration, Nevada Test Site, Mercury, Nevada } \\
\hline \multicolumn{4}{|c|}{ Responsible Facility Owner: Thomas A. Thiele, Project Manager, Industrial Sites, Environmental Restoration Project } \\
\hline Chief Inspector: Glenn Richardson & Title: Task & anager & Organization: Environmental Restoration \\
\hline Assistant Inspector: Dudley Emer & Title: & $f$ & Organization: Environmental Restoration \\
\hline
\end{tabular}

\section{A. GENERAL INSTRUCTIONS}

- Complete all checklist items.

- If a SHADED BOX is checked, provide detailed information regarding what was found and/or appropriate references to other documents that have the information (e.g., Maintenance Order Form for CAU 91 dated 2/15/2008).

- All documentation must be legible and clear.

\begin{tabular}{|c|c|c|c|}
\hline B. PREPARATION (To be competed prior to site visit) & YES & NO & EXPLANATION (required if shaded box is checked) \\
\hline \multicolumn{4}{|l|}{ 1. Has the Post-Closure Permit been reviewed? } \\
\hline \multicolumn{4}{|l|}{ 2. Has the Post-Closure Permit application been reviewed? } \\
\hline \multicolumn{4}{|l|}{ 3. Has the Post-Closure Plan been reviewed? } \\
\hline \multicolumn{4}{|l|}{ 4. Have the site as-built plans and site base map been reviewed? } \\
\hline \multicolumn{4}{|l|}{ 5. Have the previous inspection reports been reviewed? } \\
\hline \multicolumn{4}{|l|}{ a. Were anomalies or trends detected on previous inspections? } \\
\hline b. Was maintenance performed? & & & \\
\hline \multicolumn{4}{|l|}{ 6. Have the site maintenance and repair records been reviewed? } \\
\hline $\begin{array}{l}\text { a. If so, has site repair resulted in a change from as-built } \\
\text { conditions? }\end{array}$ & & & NA \\
\hline $\begin{array}{l}\text { b. If yes (to } 6 \mathrm{a} \text { ), are revised as-built plans available that reflect } \\
\text { repair changes? }\end{array}$ & & & NA \\
\hline
\end{tabular}

\section{SITE INSPECTION PREPARATION}

Assemble the following, as needed, to conduct inspections:
a. Camera, digital storage drive, and extra batteries
b. Keys to locks
c. Clipboard
d. Tape measure
e. Radio, pager, etc.
f. Previous Post-Closure Report, Inspection Checklists, repair records, and as-built plans
g. Other miscellaneous support equipment 


\section{POST-CLOSURE INSPECTION CHECKLIST}

\section{CAU 91: AREA 3 U-3fi INJECTION WELL - CAS 03-20-03: UD-6 and UD-6s Disposal Holes}

\section{SITE INSPECTION}

- The site inspection is a walking inspection of the entire site (i.e., the area within 1,000 feet of U-3fi and ER-3-3), including the perimeter and sufficient transects to be able to inspect the entire surface and all features specifically described in this checklist. The checklist should be completed during the site inspection. Every monument, site marker, sign, monitoring well access, and erosion control marker will be inspected.

- If a shaded box is checked, add detailed comments to document the results of the site inspection. Information provided should be of sufficient detail to enable reconstruction of observations regarding field conditions. Information can take the form of written narrative, sketches, measurements, and annotated site maps, all of which should be placed on additional attachments (if needed) and cross-reference appropriately. Attach the additional pages and number all pages upon completion of the inspection. The completed checklist is part of the field record of the inspection.

- Field notes taken to assist in completion of this checklist will become part of the inspection record. No form is specified for field notes, and additional field notes are not required if the checklist and associated attachments adequately describe site conditions.

1. Adjacent off-site features:

a. Are there any new activities or features in the vicinity that could potentially affect the site (e.g., activities that change the flow of surface water or are encroaching the unit)?

2. Fences, gates, and signs:

a. Is there damage to or a break in the fence?

b. Have any fence posts been damaged or their anchoring weakened?

c. Is the gate intact and functional?

d. Does the gate show evidence of tampering or damage?

c. Was the gate locked?

f. Are any of the use restriction signs damaged or missing?

g. Are all use restriction signs legible?

h. How many use restriction signs need to be replaced?

i. Other?

3. Waste unit cover:

a. Is there evidence of settling?

b. Is there evidence of cracking?

c. Is there evidence of erosion (wind or water)?

d. Is there evidence of human intrusion onto the cover?

c. Is there evidence of large animal intrusion onto the cover?

f. Is there evidence of animal burrowing?

g. Is vegetation growing on the cover?

h. Other (including trash, debris, etc within fenced area)?

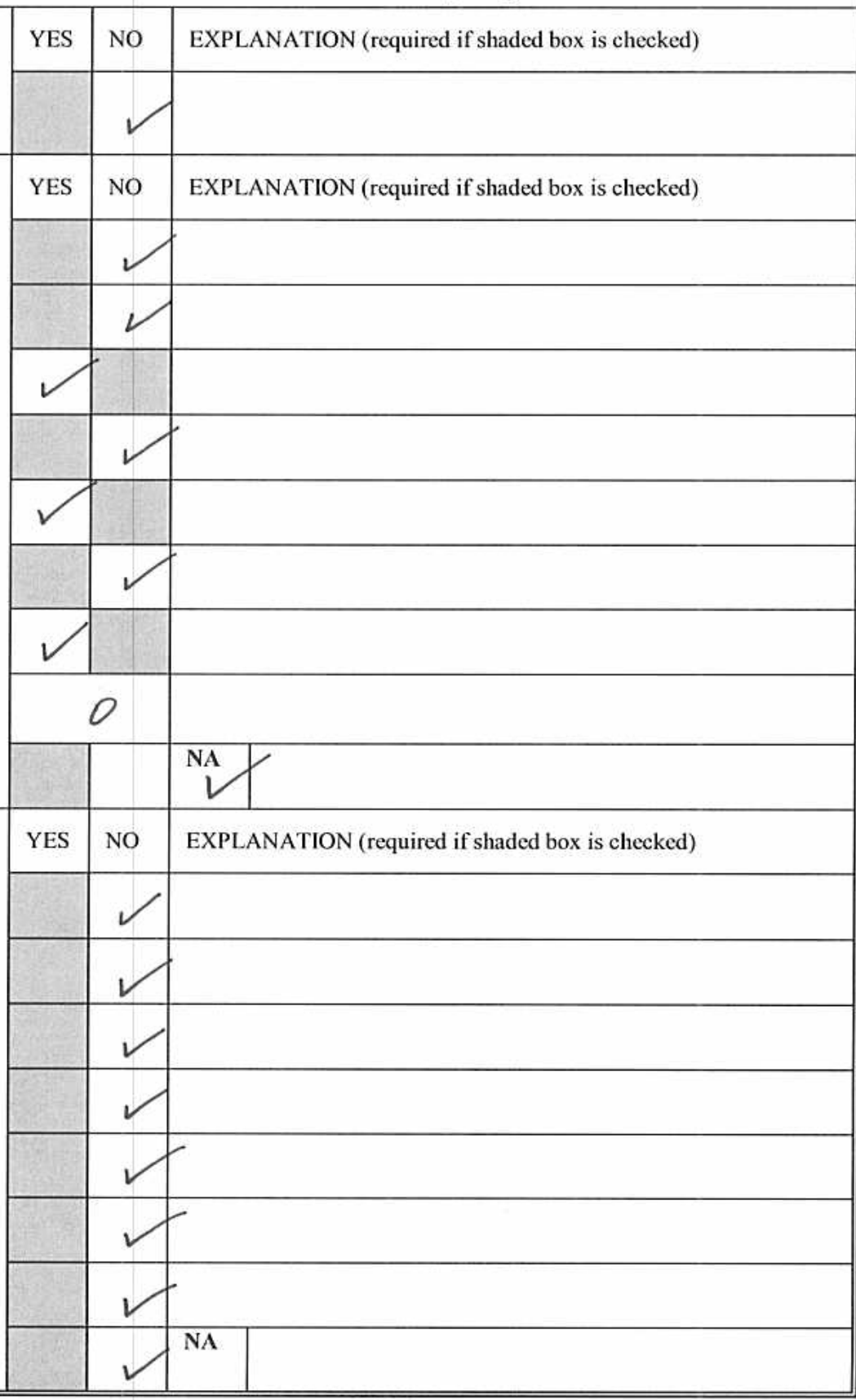




\section{POST-CLOSURE INSPECTION CHECKLIST}

\section{CAU 91: AREA 3 U-3fi INJECTION WELL - CAS 03-20-03: UD-6 and UD-6s Disposal Holes}

4. Photograph Instructions:

- A standard set of ten (10) color photographs is required to be taken during each inspection of CAU 91:

- Four (4) from the center of the unit, one in each compass direction (i.e., N, S, E, W)

- Four (4) of the unit from outside the fence, one in each compass direction

- Two (2) of the ER3-3 monitoring well surface with compass directions (N and S) noted on the photograph log

- In addition, all anomalous features or new features (such as changes in adjacent area land use) are to be photographed.

- Additional photographs may also be taken.

- A photograph log entry will be made for each photograph taken.

5. Photograph Documentation:

a. Have all photographs been taken as required by the photograph instructions?

b. Has a photograph log been prepared?

c. How many photographs were taken?

d. Other?

\section{E. FIELD CONCLUSIONS}

1. Are more frequent inspections required?

2. Are existing maintenance/repair actions satisfactory?

3. Are general housekeeping (i.e., "minor") maintenance/repair actions needed?

4. Are there any deficiencies that require a remedy other than general housekeeping (i.e., "minor") repairs?

5. Will necessary repairs change the as-built condition of the unit?

6. Were there any indications of surface or subsurface subsidence or settling?

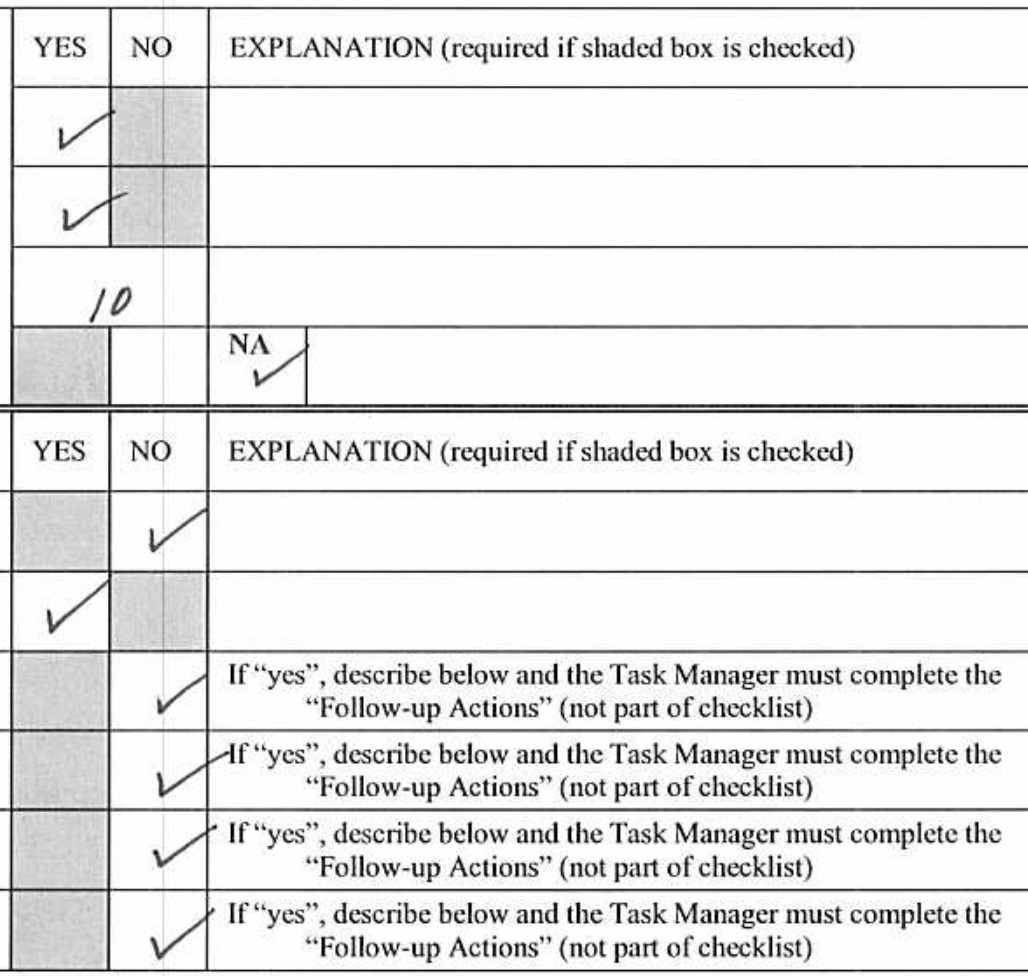

7. Field conclusions/recommendations:- All UR signage and ckain-link fencing are in excellent condition. There is no evidence of damage to the aboveground monument. There is no presence of vegetation growth on the soil cover or surrounding the concrete pad. There are no issnes or concerns at this site. 


\section{POST-CLOSURE INSPECTION CHECKLIST}

\section{CAU 91: AREA 3 U-3fi INJECTION WELL - CAS 03-20-03: UD-6 and UD-6s Disposal Holes}

\section{F. CERTIFICATION}

I have conducted an inspection of CAU 91, Area 3 U-3fi Injection Well, in accordance with the procedures of the Post-Closure Permit (including the PostClosure Plan) as recorded on this checklist, attached sheets, field notes, photographs, and photograph logs.

Chief Inspector's Signatur/s/: Glenn Richardson Date: $3 / 17 / 10$

Printed Name: Glenn Kichar Jon

Title: Task Manager

Required Attachments:

1. Field Notes (if any)

2. Photos (or note File Location: S:INTS\ER SharelPhotos $(C A U 091 \backslash 2010 \backslash 03-17-2010$ inspection )

Distribution: Original - Industrial Sites Project Manager

Copy - Task Manager

\section{G. VERIFICATION}

I have reviewed this checklist and attachments and have verified that it is complete.

Signature: /s/: Reed Poderis

Printed Name: Thomas A. Thiele (or designee)

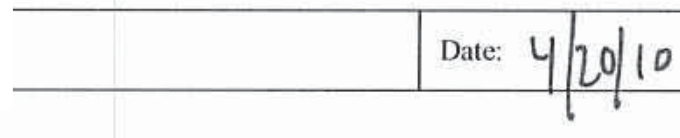

Distribution: Original - Task Manager 


\section{POST-CLOSURE INSPECTION CHECKLIST}

\section{CAU 91: AREA 3 U-3fi INJECTION WELL - CAS 03-20-03: UD-6 and UD-6s Disposal Holes}

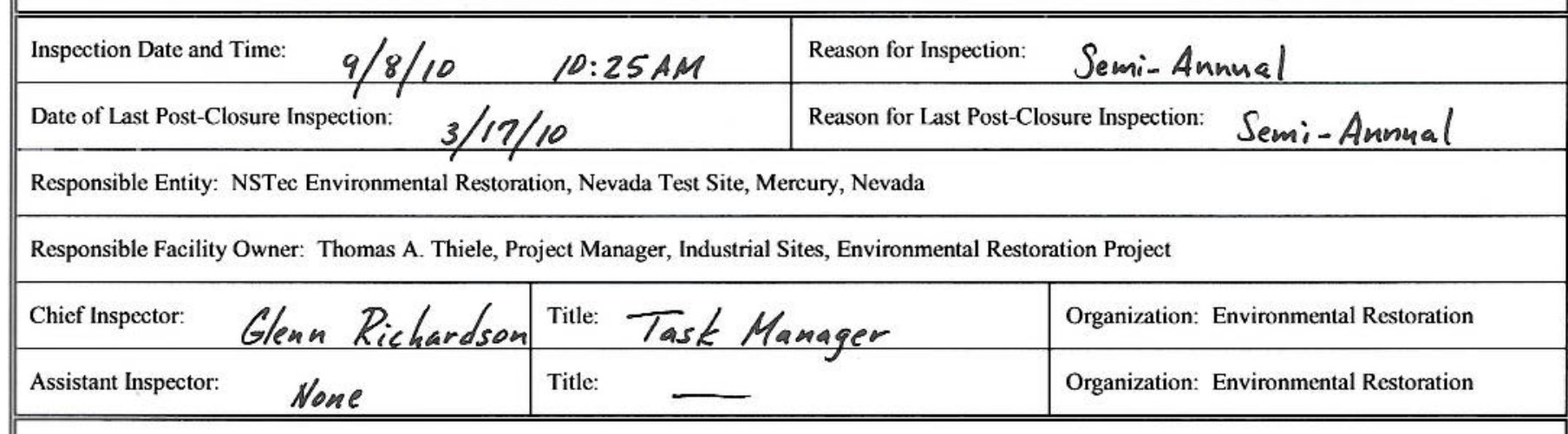

A. GENERAL INSTRUCTIONS

- Complete all checklist items.

- If a SHADED BOX is checked, provide detailed information regarding what was found and/or appropriate references to other documents that have the information (e.g., Maintenance Order Form for CAU 91 dated 2/15/2008).

- All documentation must be legible and clear.

\begin{tabular}{|c|c|c|c|c|}
\hline B. PREPARATION (To be competed prior to site visit) & YES & No & \multicolumn{2}{|c|}{ EXPLANATION (required if shaded box is checked) } \\
\hline \multicolumn{5}{|l|}{ 1. Has the Post-Closure Permit been reviewed? } \\
\hline \multicolumn{5}{|l|}{ 2. Has the Post-Closure Permit application been reviewed? } \\
\hline \multicolumn{5}{|l|}{ 3. Has the Post-Closure Plan been reviewed? } \\
\hline \multicolumn{5}{|l|}{ 4. Have the site as-built plans and site base map been reviewed? } \\
\hline \multicolumn{5}{|l|}{ 5. Have the previous inspection reports been reviewed? } \\
\hline \multicolumn{5}{|l|}{ a. Were anomalies or trends detected on previous inspections? } \\
\hline \multicolumn{5}{|l|}{ b. Was maintenance performed? } \\
\hline $\begin{array}{l}\text { b. If yes (to } 6 a \text { ), are revised as-built plans available that reflect } \\
\text { repair changes? }\end{array}$ & & & NA & \\
\hline
\end{tabular}

\section{SITE INSPECTION PREPARATION}

Assemble the following, as needed, to conduct inspections:

a. Camera, digital storage drive, and extra batteries

b. Keys to locks

c. Clipboard

d. Tape measure

e. Radio, pager, etc.

f. Previous Post-Closure Report, Inspection Checklists, repair records, and as-built plans

g. Other miscellancous support equipment 


\section{POST-CLOSURE INSPECTION CHECKLIST}

\section{CAU 91: AREA 3 U-3fi INJECTION WELL - CAS 03-20-03: UD-6 and UD-6s Disposal Holes}

\section{SITE INSPECTION}

- The site inspection is a walking inspection of the entire site (i.e., the area within 1,000 feet of U-3fi and ER-3-3), including the perimeter and sufficient transects to be able to inspect the entire surface and all features specifically described in this checklist. The checklist should be completed during the site inspection. Every monument, site marker, sign, monitoring well access, and erosion control marker will be inspected.

- If a shaded box is checked, add detailed comments to document the results of the site inspection. Information provided should be of sufficient detail to enable reconstruction of observations regarding field conditions. Information can take the form of written narrative, sketches, measurements, and annotated site maps, all of which should be placed on additional attachments (if needed) and cross-reference appropriately. Attach the additional pages and number all pages upon completion of the inspection. The completed checklist is part of the field record of the inspection.

- Field notes taken to assist in completion of this checklist will become part of the inspection record. No form is specified for field notes, and additional field notes are not required if the checklist and associated attachments adequately describe site conditions.

1. Adjacent off-site features:

a. Are there any new activities or features in the vicinity that could potentially affect the site (e.g., activities that change the flow of surface water or are encroaching the unit)?

2. Fences, gates, and signs:

a. Is there damage to or a break in the fence?

b. Have any fence posts been damaged or their anchoring weakened?

c. Is the gate intact and functional?

d. Does the gate show evidence of tampering or damage?

e. Was the gate locked?

f. Are any of the use restriction signs damaged or missing?

g. Are all use restriction signs legible?

h. How many use restriction signs need to be replaced?

i. Other?

3. Waste unit cover:

a. Is there evidence of settling?

b. Is there evidence of cracking?

c. Is there evidence of erosion (wind or water)?

d. Is there evidence of human intrusion onto the cover?

e. Is there evidence of large animal intrusion onto the cover?

f. Is there evidence of animal burrowing?

g. Is vegetation growing on the cover?

h. Other (including trash, debris, etc within fenced area)?

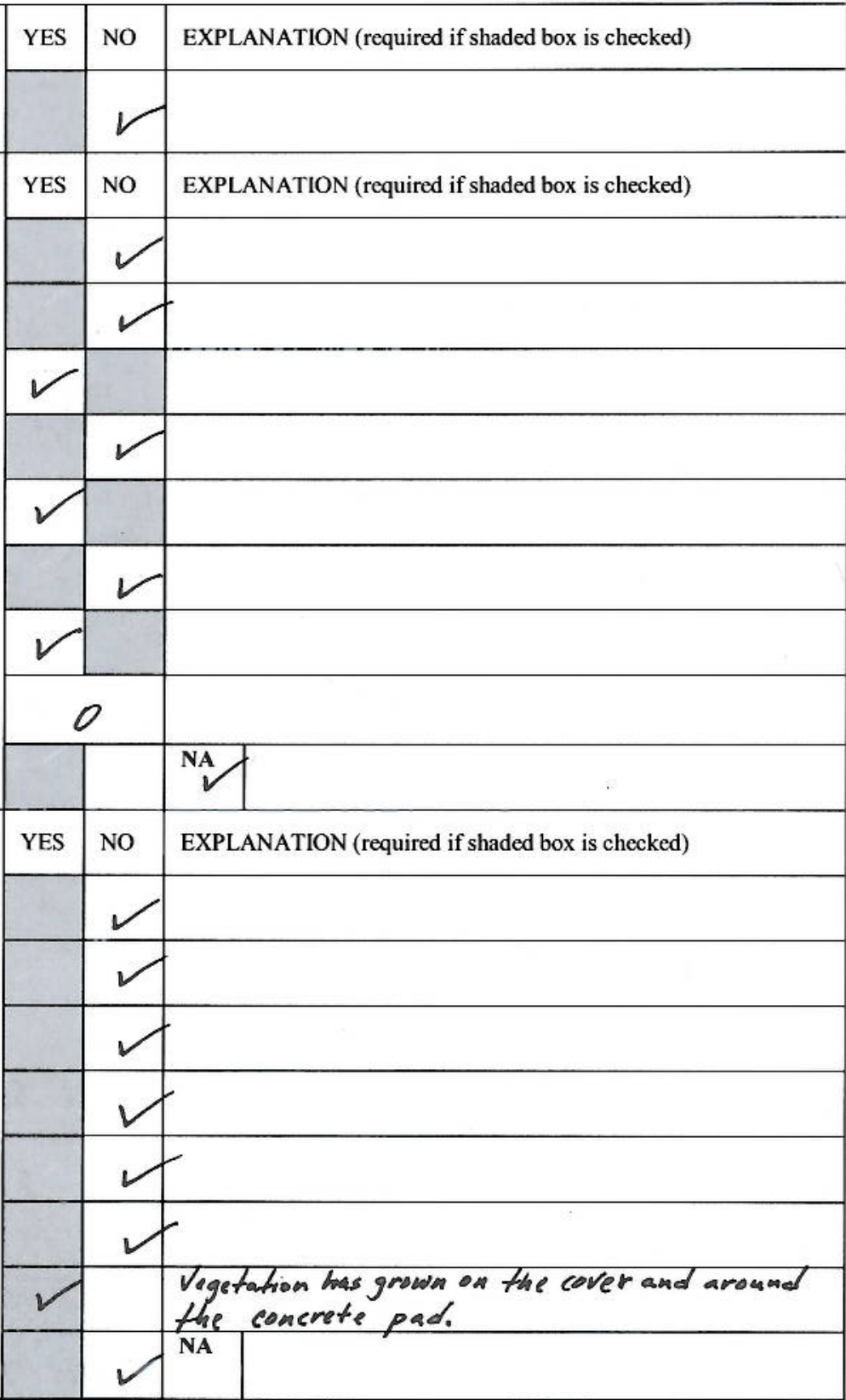

Page 2 of $\underline{4}$ 


\section{POST-CLOSURE INSPECTION CHECKLIST}

\section{CAU 91: AREA 3 U-3fi INJECTION WELL - CAS 03-20-03: UD-6 and UD-6s Disposal Holes}

4. Photograph Instructions:

- A standard set of ten (10) color photographs is required to be taken during each inspection of CAU 91:

- Four (4) from the center of the unit, one in each compass direction (i.e., N, S, E, W)

- Four (4) of the unit from outside the fence, one in each compass direction

- Two (2) of the ER3-3 monitoring well surface with compass directions (N and S) noted on the photograph log

- In addition, all anomalous features or new features (such as changes in adjacent area land use) are to be photographed.

- Additional photographs may also be taken.

- A photograph log entry will be made for each photograph taken.

5. Photograph Documentation:

a. Have all photographs been taken as required by the photograph instructions?

b. Has a photograph log been prepared?

c. How many photographs were taken?

d. Other?

\section{E. FIELD CONCLUSIONS}

1. Are more frequent inspections required?

2. Are existing maintenance/repair actions satisfactory?

3. Are general housekeeping (i.e., "minor") maintenance/repair actions needed?

4. Are there any deficiencies that require a remedy other than general housekeeping (i.e., "minor") repairs?

5. Will necessary repairs change the as-built condition of the unit?

6. Were there any indications of surface or subsurface subsidence or settling?

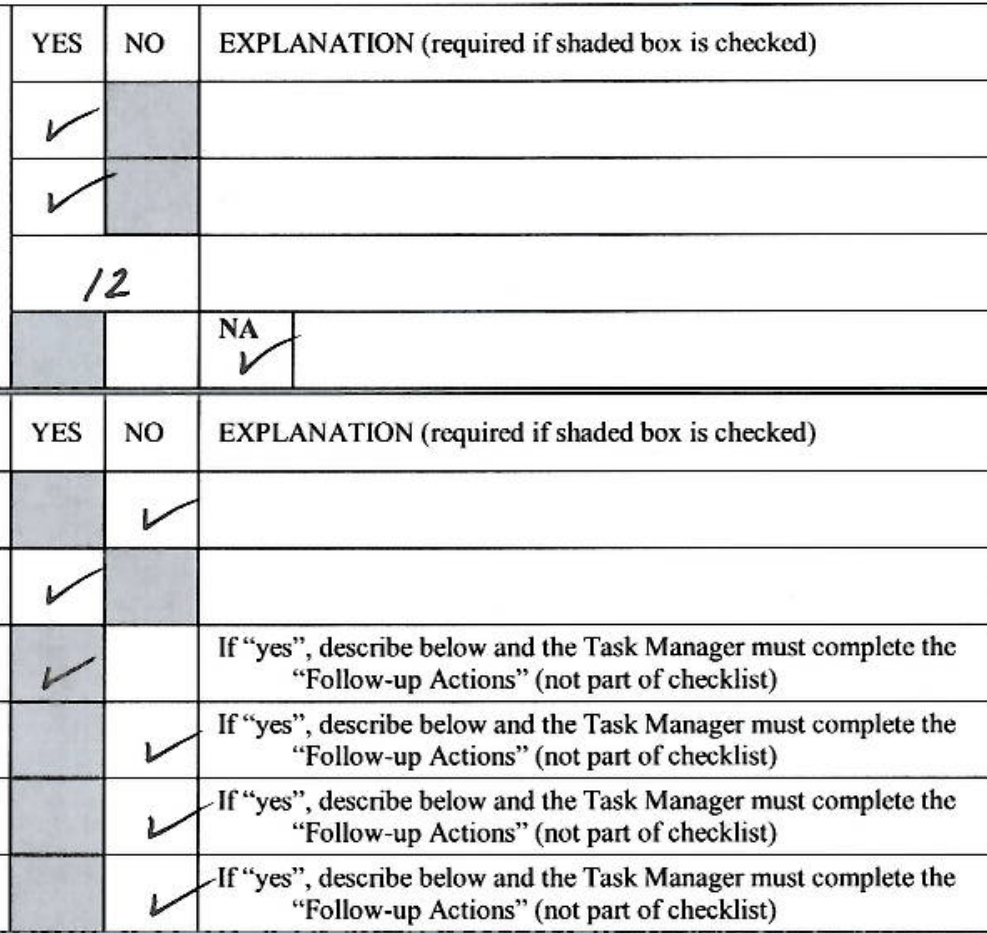

7. Field conclusions/recommendations: The use restriction signage and chain-link fencing are in excellent condition. There is no evidence of animal burrowing, subsidence, or settling. A significant amomat of vegetation had grown on the cover and around the concrete pad. Vegetation removal is necessary within the regulatory period to remain in compliance. In addition, an herbicide application may be used. 


\section{POST-CLOSURE INSPECTION CHECKLIST}

\section{CAU 91: AREA 3 U-3fi INJECTION WELL - CAS 03-20-03: UD-6 and UD-6s Disposal Holes}

\section{F. CERTIFICATION}

I have conducted an inspection of CAU 91, Area 3 U-3fi Injection Well, in accordance with the procedures of the Post-Closure Permit (including the PostClosure Plan) as recorded on this checklist, attached sheets, field notes, photographs, and photograph logs.

Chicf Inspector's Signatis/: Ĝlenn Ríchardson Date: $9 / 8 / 10$

Printed Name: Glenn Richardson $\quad$ Title: Task Manager

Required Attachments:

1. Field Notes (if any)
2. Photos (or note File Location: S: INTSLER SharelPhotosl CAu 092 $2010 \backslash 09-08$-2010 Inspectiont

Distribution: Original - Industrial Sites Project Manager

Copy - Task Manager

\section{G. VERIFICATION}

I have reviewed this chech fish and attachments and have verified that it is complete.

Signature: /s/: Reed Poderis

Date: $10 / 5 / 10$

Printed Name:|Thomas A. Thiele (or designee)

Distribution: Original - Task Manager 
RCRA Post-Closure Report

Revision: 0

Date: January 2011

CORRECTIVE ACTION UNIT 92 INSPECTION CHECKLISTS 
RCRA Post-Closure Report

Revision: 0

Date: January 2011

\section{THIS PAGE INTENTIONALLY LEFT BLANK}


Inspection Requirements:

(1) Quarterly, or

(2) Rain Event of $>0.5$ inches in 24 hours

\section{POST-CLOSURE INSPECTION CHECKLIST}

\section{CAU 92: AREA 6 DECON POND FACILITY - CAS 06-05-02: Decontamination Pond (RCRA)}

\begin{tabular}{|c|c|}
\hline $12 / 15 / 09 \quad 11: 15 A M$ & Reason for Inspection: \\
\hline Date of Last Post-Closure Inspection: & Reason for Last Post-Closure Inspection: Quarterly \\
\hline Date of Last Rain Event: & Quantity of Rainfall in that event: 0.73 inches \\
\hline
\end{tabular}

Responsible Entity: NSTec Environmental Restoration, Nevada Test Site, Mercury, Nevada

Responsible Facility Owner: Thomas A. Thiele, Project Manager, Industrial Sites, Environmental Restoration Project

\begin{tabular}{||l|l|l|}
\hline Chief Inspector: Glenn Richardson & Title: Task Manager & Organization: Environmental Restoration \\
\hline Assistant Inspector: Greq Doyle & Title: Sr. Scien fist & Organization: Environmental Restoration \\
\hline \hline
\end{tabular}

\section{A. GENERAL INSTRUCTIONS}

- Complete all checklist items.

- If a SHADED BOX is checked, provide detailed information regarding what was found and/or appropriate references to other documents that have the information (e.g., Maintenance Order Form for CAU 92 dated 2/15/2008).

- All documentation must be legible and clear.

\begin{tabular}{|c|c|c|c|}
\hline B. PREPARATION (To be competed prior to site visit) & YES & NO & EXPLANATION (required if shaded box is checked) \\
\hline \multicolumn{4}{|l|}{ 1. Has the Post-Closure Permit been reviewed? } \\
\hline \multicolumn{4}{|l|}{ 2. Has the Post-Closure Permit application been reviewed? } \\
\hline \multicolumn{4}{|l|}{ 3. Has the Post-Closure Plan been reviewed? } \\
\hline \multicolumn{4}{|l|}{ 4. Have the site as-built plans and site base map been reviewed? } \\
\hline \multicolumn{4}{|l|}{ 5. Have the previous inspection reports been reviewed? } \\
\hline \multicolumn{4}{|l|}{ a. Were anomalies or trends detected on previous inspections? } \\
\hline b. Was maintenance performed? & & & $\begin{array}{l}\text { Vegetation removal was performed and } \\
\text { completed in Nov. } 200 \% \text {. }\end{array}$ \\
\hline \multicolumn{4}{|l|}{ 6. Have the site maintenance and repair records been reviewed? } \\
\hline $\begin{array}{l}\text { a. If so, has site repair resulted in a change from as-built } \\
\text { conditions? }\end{array}$ & & & NA \\
\hline $\begin{array}{l}\text { b. If yes (to } 6 \mathrm{a} \text { ), are revised as-built plans available that reflect } \\
\text { repair changes? }\end{array}$ & & & NA \\
\hline
\end{tabular}

\section{SITE INSPECTION PREPARATION}

Assemble the following, as needed, to conduct inspections:

a. Camera, digital storage drive, and extra batteries

b. Keys to locks

c. Clipboard

d. Tape measure

e. Radio, pager, etc.

f. Previous Post-Closure Report, Inspection Checklists, repair records, and as-built plans

g. Other miscellaneous support equipment 
Inspection Requirements:

(1) Quarterly, or

(2) Rain Event of $>0.5$ inches in 24 hours

\section{POST-CLOSURE INSPECTION CHECKLIST}

\section{CAU 92: AREA 6 DECON POND FACILITY - CAS 06-05-02: Decontamination Pond (RCRA)}

\section{SITE INSPECTION}

- The site inspection is a walking inspection of the entire site including the perimeter and sufficient transects to be able to inspect the entire surface and all features specifically described in this checklist. The checklist should be completed during the site inspection.

- If a shaded box is checked, add detailed comments to document the results of the site inspection. Information provided should be of sufficient detail to enable reconstruction of observations regarding field conditions. Information can take the form of written narrative, sketches, measurements, and annotated site maps, all of which should be placed on additional attachments (if needed) and cross-reference appropriately. Attach the additional pages and number all pages upon completion of the inspection. The completed checklist is part of the field record of the inspection.

- Field notes taken to assist in completion of this checklist will become part of the inspection record. No form is specified for field notes, and additional field notes are not required if the checklist and associated attachments adequately describe site conditions.

1. Adjacent off-site features:

a. Are there any new activities or features on Yucca Lake that could potentially affect the site (e.g., activities that change the flow of surface water or are encroaching the unit)?

2. Fencing, gates, and signs:

a. Is there damage to or a break in the fence?

b. Have any fence posts been damaged or their anchoring weakened?

c. Are any of the use restriction signs damaged or missing?

d. Are all use restriction signs legible?

c. How many use restriction signs need to be replaced?

f. Are any of the URMA signs damaged or missing?

g. Are all URMA signs legible?

h. How many URMA signs need to be replaced?

i. Is the gate intact and functional?

j. Does the gate show evidence of tampering or damage?

k. Was the gate locked?

1. Does the wave barrier require repair?

$\mathrm{m}$. Is there standing water within or at the fenceline?

If yes, what is the playa water elevation, as measured on the depth gauge attached to the fence perimeter?

n. Other?

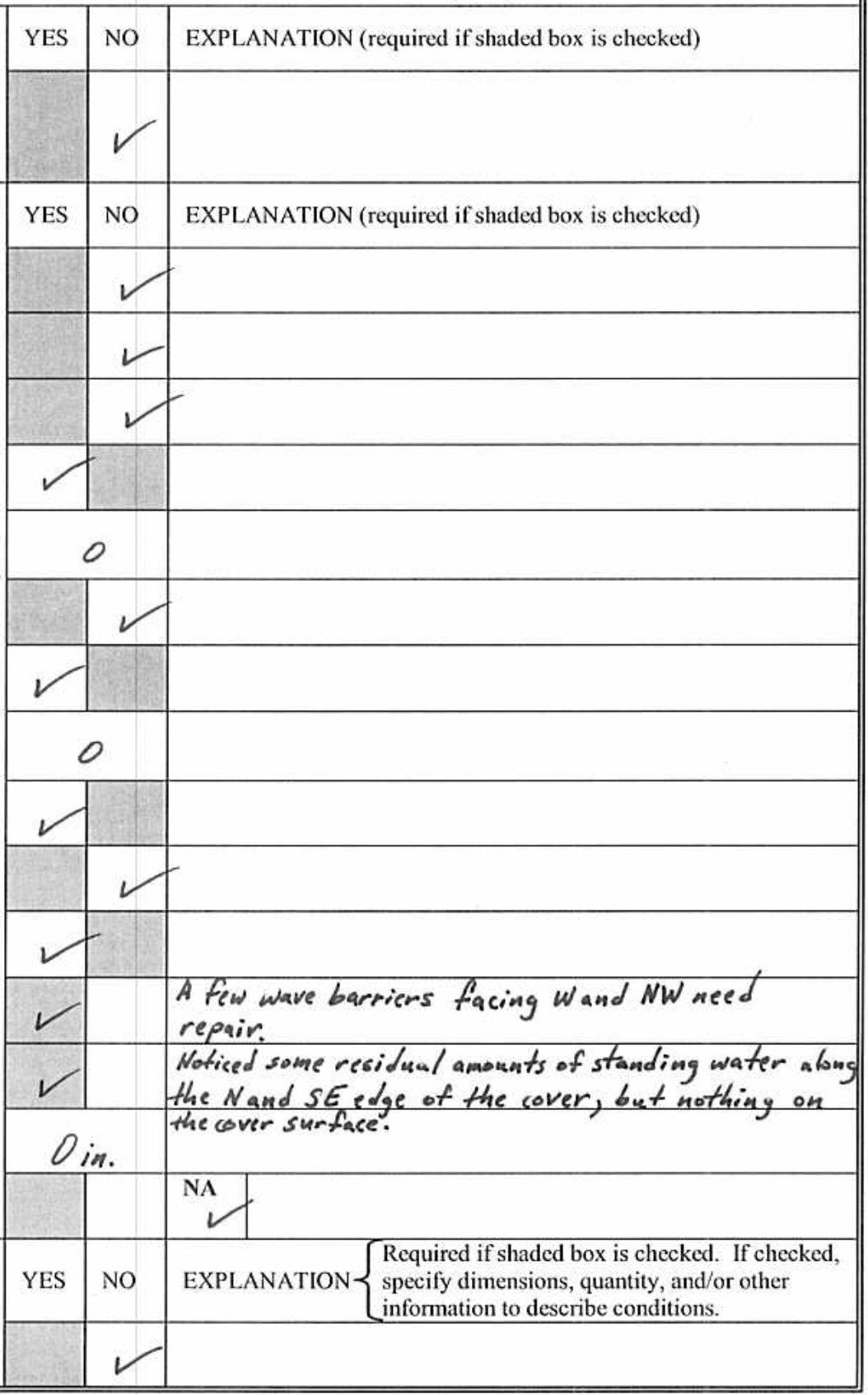

a. Is there evidence of settling? 
Inspection Requirements:

(1) Quarterly, or

(2) Rain Event of $>0.5$ inches in 24 hours

\section{POST-CLOSURE INSPECTION CHECKLIST}

\section{CAU 92: AREA 6 DECON POND FACILITY - CAS 06-05-02: Decontamination Pond (RCRA)}

3. Waste unit cover (continued):

b. Is there evidence of cracking?

c. Is there evidence of erosion (wind or water)?

d. Is there evidence of human intrusion onto the cover?

e. Is there evidence of large animal intrusion onto the cover?

f. Is there evidence of animal burrowing?

g. Is vegetation growing on the cover?

h. Other (including trash, debris, etc within fenced area)?

4. Subsidence survey markers:

a. Have any of the five (5) subsidence survey markers been disturbed?

b. Do natural processes threaten the integrity of any subsidence survey marker?

c. Is there excessive vegetation around the subsidence survey markers?

d. Other?

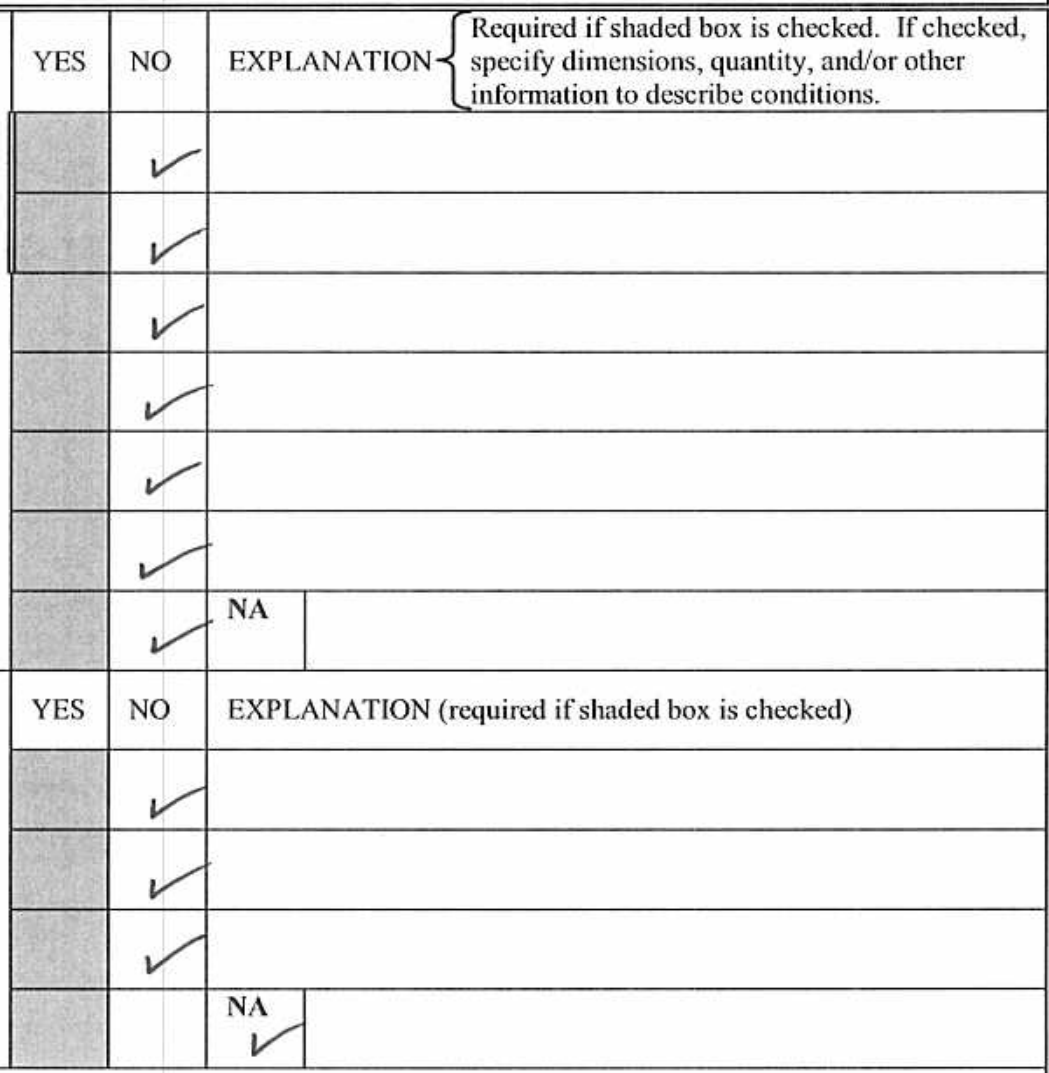

5. Photograph Instructions:

- A standard set of color photographs is required. Eight photographs must be taken during each inspection of CAU 92 :

- Four (4) from the center of the unit, one in each compass direction (i.e., N, S, E, W)

- Four (4) of the unit from outside the fence, one in each compass direction (i.e., N, S, E, W).

- In addition, all anomalous features or new features (such as changes in adjacent area land use) are to be photographed.

- Additional photographs may also be taken.

- A photograph log entry will be made for each photograph taken.

6. Photograph Documentation: a. Have all photographs been taken as required by the
photograph instructions?

b. Has a photograph log been prepared?

c. How many photographs were taken?

d. Other?

\section{E. FIELD CONCLUSIONS}

1. Are more frequent inspections required?

2. Are existing maintenance/repair actions satisfactory?

3. Are general housekeeping (i.e., "minor") maintenance/repair actions needed (includes small - less than 2 inches deep cracks or settling imperfections of the cover)? [minor repairs]

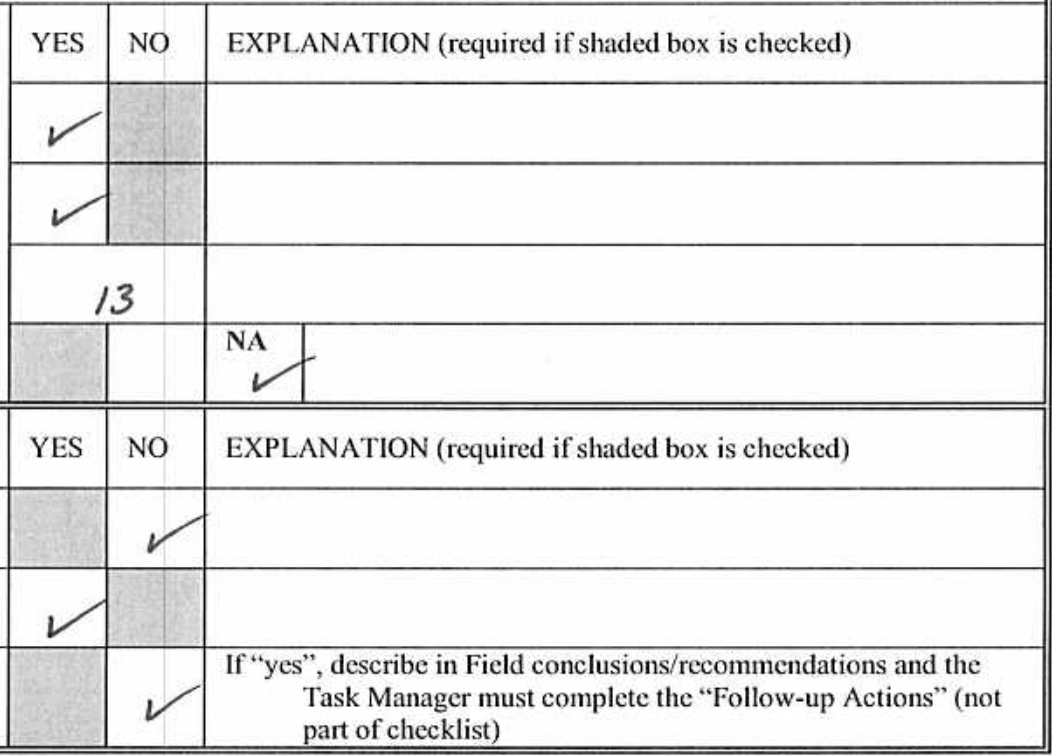


Inspection Requirements:

(1) Quarterly, or

(2) Rain Event of $>0.5$ inches in 24 hours

\section{POST-CLOSURE INSPECTION CHECKLIST}

\section{CAU 92: AREA 6 DECON POND FACILITY - CAS 06-05-02: Decontamination Pond (RCRA)}

\begin{tabular}{l}
\hline E. FIELD CONCLUSIONS (continued) \\
\hline \hline 4. Are there any deficiencies that require a remedy other than \\
general housekeeping or small (less than 2 inches deep) cracks \\
or settling imperfections of the cover? [i.e., more than \\
"minor repairs"]
\end{tabular}

5. Will necessary repairs change the as-built condition of the unit?

\begin{tabular}{|l|l|l}
\hline YES & NO & EXPLANATION (required if shaded box is checked) \\
& & $\begin{array}{l}\text { If "yes", describe below and the Task Manager must complete the } \\
\text { "Follow-up Actions" (not part of checklist) }\end{array}$ \\
\hline & $\begin{array}{l}\text { If "yes", describe below and the Task Manager must complete the } \\
\text { "Follow-up Actions" (not part of checklist) }\end{array}$
\end{tabular}
"Follow-up Actions" (not part of checklist)

6. Field conclusions/recommendations: The site had no evidence of subsidence, settling, or animal burrowing. There was no new regetation on or along the edges of the waste unit cover. The radiological and $U R$ signage are in great condition. There was no evidence of damage to the chainlink fencing; however, a few wave barriers facing west and northwest are going to need repair. Repairs will be completed within 60 days. In addition, there was some residual amounts of standing water along the north and sontheast edge of the cover, but nothing was observed on the cover sunface.

\section{F. CERTIFICATION}

I have conducted an inspection of CAU 92, Area 6 Decon Pond Facility, in accordance with the procedures of the Post-Closure Permit (including the Post-Closure Plan) as recorded on this checklist, attached sheets, field notes, photographs, and photograph logs.

\begin{tabular}{l|l|l}
\hline Chief Inspector's signaturls/: Glenn Richardson & Date: $12 / 15 / 09$ \\
\hline Printed Name: Glenn Richardsen & Title: Task Manager
\end{tabular}

Required Attachments:

1. Field Notes

2. Photos (or note File Location: S:INTS ER Share 1 Photos I CAU 921 2009/12-15-2009 cAu 92 Inspection

Distribution: Original - Industrial Sites Project Manager

Copy - Task Manager

\section{G. VERIFICATION}

I have revieygd this checklist and attachments and have verified that it is complete.

Signature: /s/: Reed Poderis

Printed Name: Thomas A. Thiele (or designee)

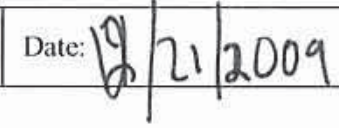

Distribution: Original - Task Manager 
Inspection Requirements:

(1) Quarterly, or

(2) Rain Event of $>0.5$ inches in 24 hours

\section{POST-CLOSURE INSPECTION CHECKLIST}

CAU 92: AREA 6 DECON POND FACILITY - CAS 06-05-02: Decontamination Pond (RCRA)

\begin{tabular}{|c|c|c|c|}
\hline \multicolumn{2}{|l|}{ Inspection Date and Time: } & Reason for Inspection: & Precipitation Event >0.5in. \\
\hline \multicolumn{2}{|l|}{ Date of Last Post-Closure Inspection: } & \multicolumn{2}{|c|}{ Reason for Last Post-Closure Inspection: Quarterly } \\
\hline \multicolumn{2}{|l|}{ Date of Last Rain Event: } & \multicolumn{2}{|c|}{ Quantity of Rainfall in that event: 2.62 inches } \\
\hline \multicolumn{4}{|c|}{ Responsible Entity: NSTec Environmental Restoration, Nevada Test Site, Mercury, Nevada } \\
\hline \multicolumn{4}{|c|}{ Responsible Facility Owner: Thomas A. Thiele, Project Manager, Industrial Sites, Environmental Restoration Project } \\
\hline Chief Inspector: Glenn Richardson & Title: Task & nager & Organization: Environmental Restoration \\
\hline Assistant Inspector: $D_{\text {udley Emer }}$ & Title: $S_{r}, S$ & tist & Organization: Environmental Restoration \\
\hline
\end{tabular}

\section{A. GENERAL INSTRUCTIONS}

- Complete all checklist items.

- If a SHADED BOX is checked, provide detailed information regarding what was found and/or appropriate references to other documents that have the information (e.g., Maintenance Order Form for CAU 92 dated 2/15/2008).

- All documentation must be legible and clear.

B. PREPARATION (To be competed prior to site visit)

I. Has the Post-Closure Permit been reviewed?

2. Has the Post-Closure Permit application been reviewed?

3. Has the Post-Closure Plan been reviewed?

4. Have the site as-built plans and site base map been reviewed?

5. Have the previous inspection reports been reviewed?

a. Were anomalies or trends detected on previous inspections?

b. Was maintenance performed?

If maintenance was performed, are copies of all maintenance records in the project file?

6. Have the site maintenance and repair records been reviewed?

a. If so, has site repair resulted in a change from as-built conditions?

b. If yes (to 6a), are revised as-built plans available that reflect repair changes?

\begin{tabular}{|l|l|l|l||}
\hline YES & NO & \multicolumn{2}{|l||}{ EXPLANATION (required if shaded box is checked) } \\
\hline & & & \\
\hline & & & \\
\hline & & & \\
\hline & & & \\
\hline & & & \\
\hline & & NA & \\
\hline & & NA & \\
\hline
\end{tabular}

\section{SITE INSPECTION PREPARATION}

Assemble the following, as needed, to conduct inspections:
a. Camera, digital storage drive, and extra batteries
b. Keys to locks
c. Clipboard
d. Tape measure
c. Radio, pager, etc.
f. Previous Post-Closure Report, Inspection Checklists, repair records, and as-built plans
g. Other miscellaneous support equipment 
Inspection Requirements:

(1) Quarterly, or

(2) Rain Event of $>0.5$ inches in 24 hours

\section{POST-CLOSURE INSPECTION CHECKLIST}

\section{CAU 92: AREA 6 DECON POND FACILITY - CAS 06-05-02: Decontamination Pond (RCRA)}

\section{SITE INSPECTION}

- The site inspection is a walking inspection of the entire site including the perimeter and sufficient transects to be able to inspect the entire surface and all features specifically described in this checklist. The checklist should be completed during the site inspection.

- If a shaded box is checked, add detailed comments to document the results of the site inspection. Information provided should be of sufficient detail to enable reconstruction of observations regarding field conditions. Information can take the form of written narrative, sketches, measurements, and annotated site maps, all of which should be placed on additional attachments (if needed) and cross-reference appropriately. Attach the additional pages and number all pages upon completion of the inspection. The completed checklist is part of the field record of the inspection.

- Field notes taken to assist in completion of this checklist will become part of the inspection record. No form is specified for field notes, and additional field notes are not required if the checklist and associated attachments adequately describe site conditions.

1. Adjacent off-site features:

a. Are there any new activities or features on Yucca Lake that could potentially affect the site (e.g., activities that change the flow of surface water or are encroaching the unit)?

2. Fencing, gates, and signs:

a. Is there damage to or a break in the fence?

b. Have any fence posts been damaged or their anchoring weakened?

c. Are any of the use restriction signs damaged or missing?

d. Are all use restriction signs legible?

e. How many use restriction signs need to be replaced?

f. Are any of the URMA signs damaged or missing?

g. Are all URMA signs legible?

h. How many URMA signs need to be replaced?

i. Is the gate intact and functional?

j. Does the gate show evidence of tampering or damage?

k. Was the gate locked?

1. Does the wave barrier require repair?

m. Is there standing water within or at the fenceline?

If yes, what is the playa water elevation, as measured on the depth gauge attached to the fence perimeter?

n. Other?

3. Waste unit cover:

a. Is there evidence of settling?

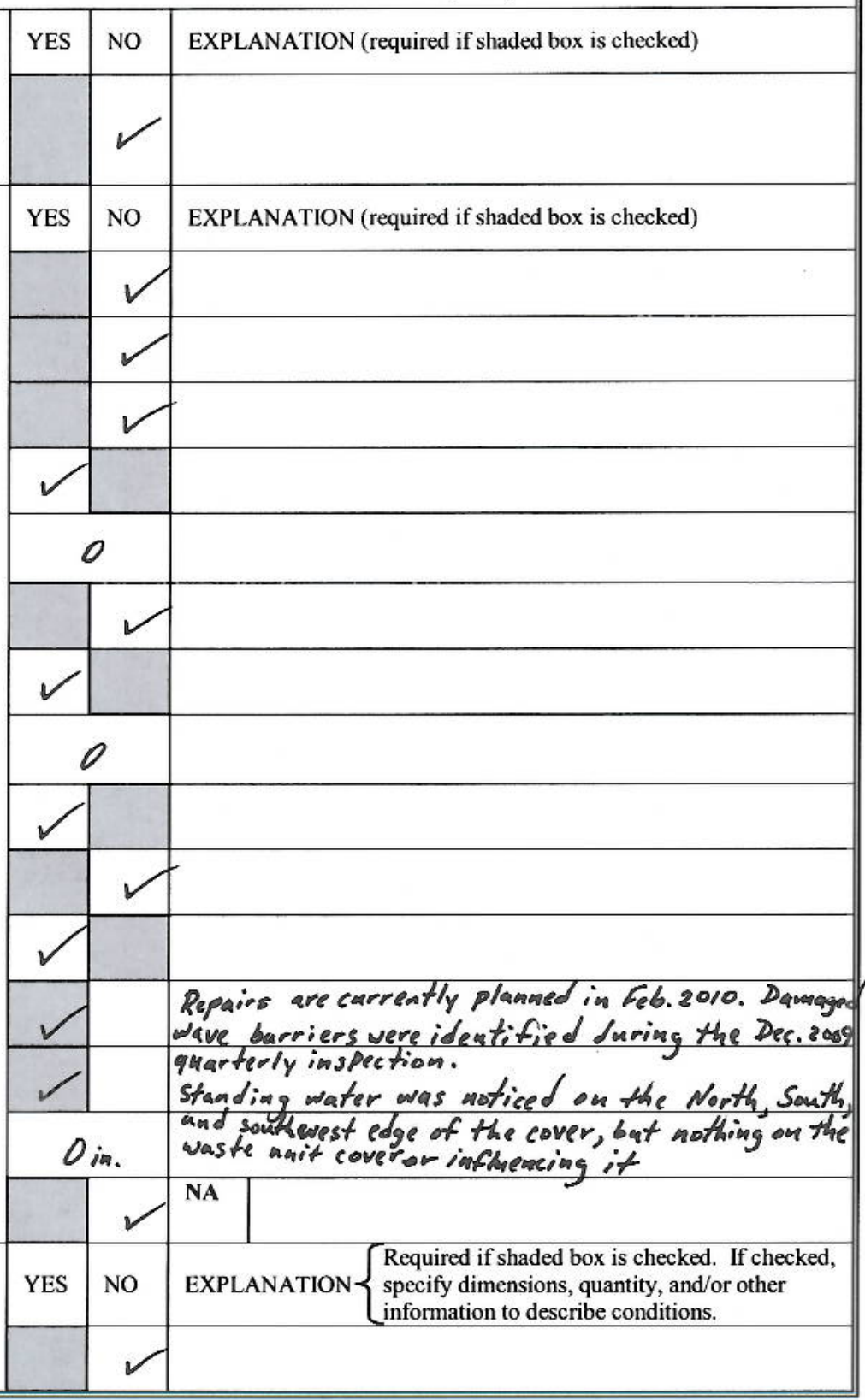


Inspection Requirements:

(1) Quarterly, or

(2) Rain Event of $>0.5$ inches in 24 hours

\section{POST-CLOSURE INSPECTION CHECKLIST}

CAU 92: AREA 6 DECON POND FACILITY - CAS 06-05-02: Decontamination Pond (RCRA)

3. Waste unit cover (continued):

b. Is there evidence of cracking?

c. Is there evidence of erosion (wind or water)?

d. Is there evidence of human intrusion onto the cover?

e. Is there evidence of large animal intrusion onto the cover?

f. Is there evidence of animal burrowing?

g. Is vegetation growing on the cover?

h. Other (including trash, debris, etc within fenced area)?

4. Subsidence survey markers:

a. Have any of the five (5) subsidence survey markers been disturbed?

b. Do natural processes threaten the integrity of any subsidence survey marker?

c. Is there excessive vegetation around the subsidence survey markers?

d. Other?

\begin{tabular}{|c|c|c|c|}
\hline YES & NO & EXPLANATION & $\begin{array}{l}\text { Required if shaded box is checked. If checked, } \\
\text { specify dimensions, quantity, and/or other } \\
\text { information to describe conditions. }\end{array}$ \\
\hline & $\checkmark$ & & \\
\hline & $\checkmark$ & & \\
\hline & 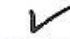 & & \\
\hline & & & \\
\hline & & & \\
\hline & $V$ & & \\
\hline & $V$ & NA & \\
\hline YES & NO & \multicolumn{2}{|c|}{ EXPLANATION (required if shaded box is checked) } \\
\hline & 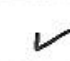 & & \\
\hline & $\sqrt{2}$ & & \\
\hline & $V$ & & \\
\hline & 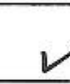 & NA & \\
\hline
\end{tabular}

5. Photograph Instructions:

- A standard set of color photographs is required. Eight photographs must be taken during each inspection of CAU 92:

- Four (4) from the center of the unit, one in each compass direction (i.e., N, S, E, W)

- Four (4) of the unit from outside the fence, one in each compass direction (i.e., N, S, E, W).

- In addition, all anomalous features or new features (such as changes in adjacent area land use) are to be photographed.

- Additional photographs may also be taken.

- A photograph log entry will be made for each photograph taken.

6. Photograph Documentation:

a. Have all photographs been taken as required by the photograph instructions?

b. Has a photograph log been prepared?

c. How many photographs were taken?

d. Other?

\section{E. FIELD CONCLUSIONS}

1. Are more frequent inspections required?

2. Are existing maintenance/repair actions satisfactory?

3. Are general housekeeping (i.e., "minor") maintenance/repair actions needed (includes small - less than 2 inches deep cracks or settling imperfections of the cover)? [minor repairs]

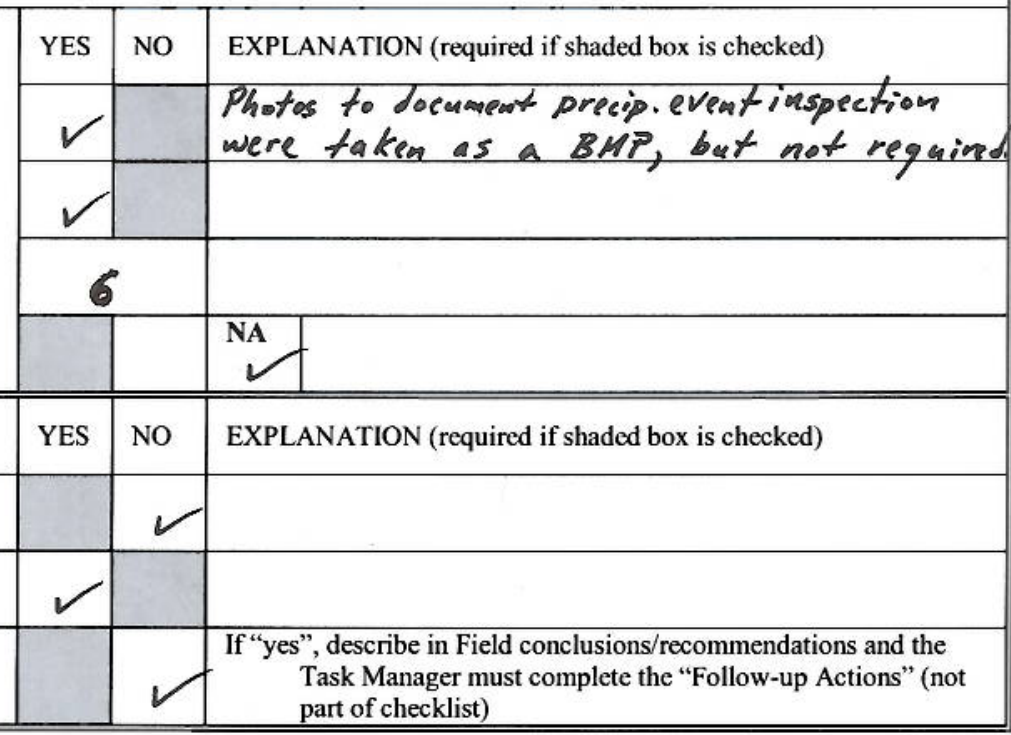


Inspection Requirements:

(1) Quarterly, or

(2) Rain Event of $>0.5$ inches in 24 hours

\section{POST-CLOSURE INSPECTION CHECKLIST}

\section{CAU 92: AREA 6 DECON POND FACILITY - CAS 06-05-02: Decontamination Pond (RCRA)}

\section{E. FIELD CONCLUSIONS (continued)}

4. Are there any deficiencies that require a remedy other than general housekecping or small (less than 2 inches deep) cracks or settling imperfections of the cover? [i.e., more than "minor repairs"]

5. Will necessary repairs change the as-built condition of the unit? \begin{tabular}{l|l|l} 
YES & NO & EXPLANATION (required if shaded box is checked)
\end{tabular}

If "yes", describe below and the Task Manager must complete the "Follow-up Actions" (not part of checklist)

If "yes", describe below and the Task Manager must complete the "Follow-up Actions" (not part of checklist)

6. Field conclusions/recommendations: Overall site conditions are good. Noticed standing water on the edges of the cover (North, Senth, Suothwest), but ne puidence of standing water was on top of the cover. There was no settling or subsidence on the waste nuit cover. The chain-lint fencing radiological ! UR signage, and surface wounments are in excellent condition. The site was well secuned and gate lockedand maintainal

\section{F. CERTIFICATION}

I have conducted an inspection of CAU 92, Area 6 Decon Pond Facility, in accordance with the procedures of the Post-Closure Permit (including the Post-Closure Plan) as recorded on this checklist, attached sheets, field notes, photographs, and photograph logs.

chief Inspector's signaturts/: Glenn Richardsolp Date: $1 / 25 / 10$

Printed Name: Glenen tichardson Title:

\section{Task Mangger}

\section{Required Attachments:}

1. Field Notes

2. Photos (or note File Location: S:INTS\ER Share Photos \CAU $92 \backslash 2010 \backslash 01-25-2010$ Precip 5 ispoction

Distribution: Original - Industrial Sites Project Manager

Copy - Task Manager

\section{G. VERIFICATION}

I have reviewed this checklist and attachments and have verified that it is complete.

signature: /s/: Reed Poderis

Date: $1 / 25 / 10$

Printed Name: Thomas A. Thiele (or designee)

Distribution: Original - Task Manager 
Inspection Requirements:

(1) Quarterly, or

(2) Rain Event of $>0.5$ inches in 24 hours

\section{POST-CLOSURE INSPECTION CHECKLIST}

\section{CAU 92: AREA 6 DECON POND FACILITY - CAS 06-05-02: Decontamination Pond (RCRA)}

\begin{tabular}{|l|l||}
\hline Inspection Date and Time: $3 / 17 / 10 \quad 1 /: 50 \mathrm{AM}$ & Reason for Inspection: Quarterly \\
\hline Date of Last Post-Closure Inspection: $1 / 25 / 10$ & Reason for Last Post-Closure Inspection: Precipitation Even A \\
\hline Date of Last Rain Event: $1 / 18 / 10$ & Quantity of Rainfall in that event: 2.62 inches \\
\hline
\end{tabular}

Responsible Entity: NSTec Environmental Restoration, Nevada Test Site, Mercury, Nevada

Responsible Facility Owner: Thomas A. Thiele, Project Manager, Industrial Sites, Environmental Restoration Project

\begin{tabular}{l|l|l|} 
Chief Inspector: Glenn Richardson & Title: Task Manager & Organization: Environmental Restoration \\
\hline Assistant Inspector: Dudley Emer & Title: Sr. Scientist & Organization: Environmental Restoration \\
\hline
\end{tabular}

\section{A. GENERAL INSTRUCTIONS}

- Complete all checklist items.

- If a SHADED BOX is checked, provide detailed information regarding what was found and/or appropriate references to other documents that have the information (e.g., Maintenance Order Form for CAU 92 dated 2/15/2008).

- All documentation must be legible and clear.

\section{B. PREPARATION (To be competed prior to site visit)}

1. Has the Post-Closure Permit been reviewed?

2. Has the Post-Closure Permit application been reviewed?

3. Has the Post-Closure Plan been reviewed?

4. Have the site as-built plans and site base map been reviewed?

5. Have the previous inspection reports been reviewed?

a. Were anomalies or trends detected on previous inspections?

b. Was maintenance performed?

If maintenance was performed, are copies of all maintenance records in the project file?

6. Have the site maintenance and repair records been reviewed?

a. If so, has site repair resulted in a change from as-built conditions?

b. If yes (to 6a), are revised as-built plans available that reflect repair changes?

\section{SITE INSPECTION PREPARATION}

Assemble the following, as needed, to conduct inspections:

a. Camera, digital storage drive, and extra batteries

b. Keys to locks

c. Clipboard

d. Tape measure

e. Radio, pager, etc.

f. Previous Post-Closure Report, Inspection Checklists, repair records, and as-built plans

g. Other miscellaneous support equipment 
Inspection Requirements:

(1) Quarterly, or

(2) Rain Event of $>0.5$ inches in 24 hours

\section{POST-CLOSURE INSPECTION CHECKLIST}

\section{CAU 92: AREA 6 DECON POND FACILITY - CAS 06-05-02: Decontamination Pond (RCRA)}

\section{SITE INSPECTION}

- The site inspection is a walking inspection of the entire site including the perimeter and sufficient transects to be able to inspect the entire surface and all features specifically described in this checklist. The checklist should be completed during the site inspection.

- If a shaded box is checked, add detailed comments to document the results of the site inspection. Information provided should be of sufficient detail to enable reconstruction of observations regarding field conditions. Information can take the form of written narrative, sketches, measurements, and annotated site maps, all of which should be placed on additional attachments (if needed) and cross-reference appropriately. Attach the additional pages and number all pages upon completion of the inspection. The completed checklist is part of the field record of the inspection.

- Field notes taken to assist in completion of this checklist will become part of the inspection record. No form is specified for field notes, and additional field notes are not required if the checklist and associated attachments adequately describe site conditions.

1. Adjacent off-site features:

a. Are there any new activities or features on Yucca Lake that could potentially affect the site (e.g., activities that change the flow of surface water or are encroaching the unit)?

2. Fencing, gates, and signs:

a. Is there damage to or a break in the fence?

b. Have any fence posts been damaged or their anchoring weakened?

c. Are any of the use restriction signs damaged or missing?

d. Are all use restriction signs legible?

e. How many use restriction signs need to be replaced?

f. Are any of the URMA signs damaged or missing?

g. Are all URMA signs legible?

h. How many URMA signs need to be replaced?

i. Is the gate intact and functional?

j. Does the gate show evidence of tampering or damage?

k. Was the gate locked?

1. Does the wave barrier require repair?

$\mathrm{m}$. Is there standing water within or at the fenceline?

If yes, what is the playa water elevation, as measured on the depth gauge attached to the fence perimeter?

n. Other?

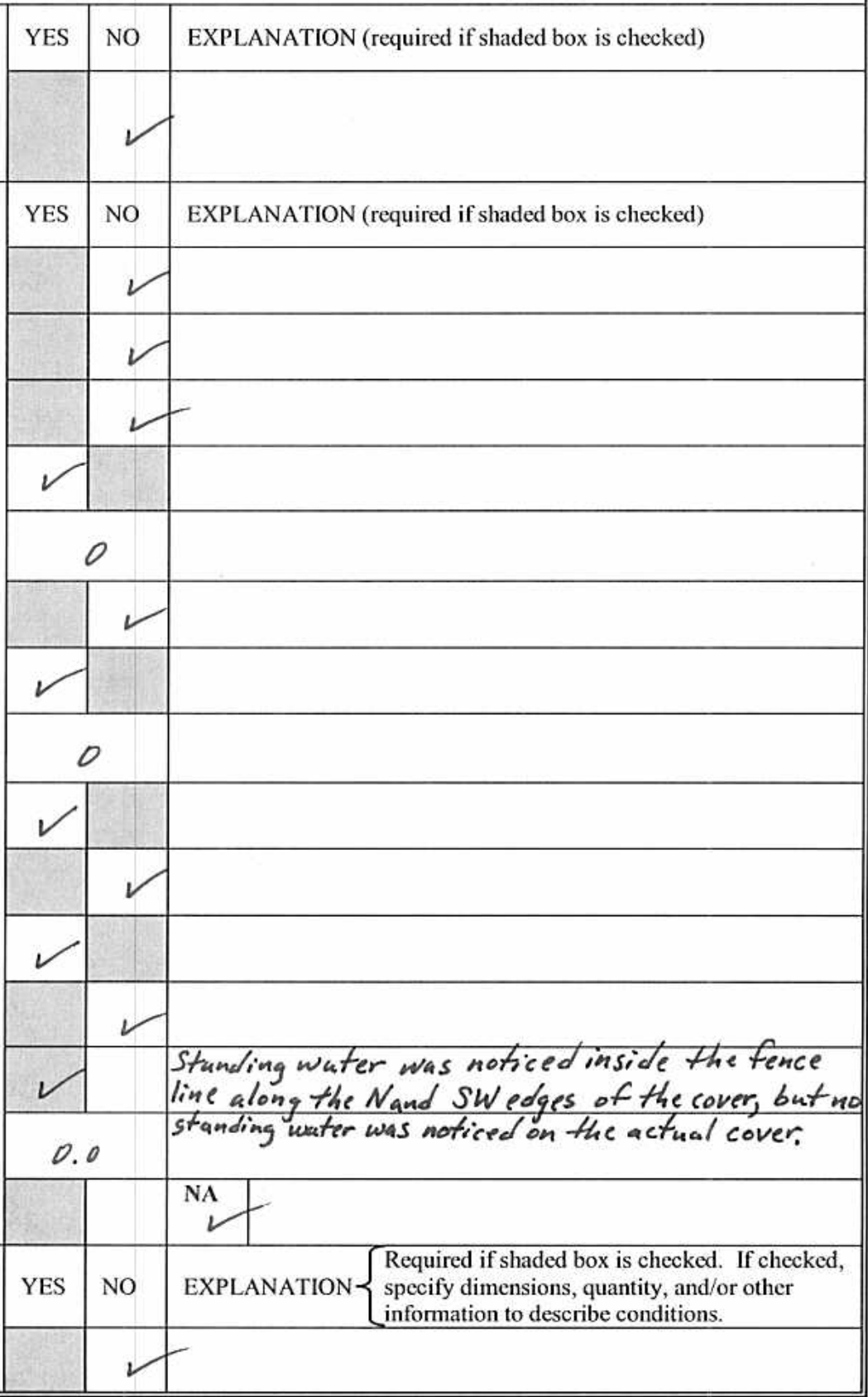


Inspection Requirements:

(1) Quarterly, or

(2) Rain Event of $>0.5$ inches in 24 hours

\section{POST-CLOSURE INSPECTION CHECKLIST}

\section{CAU 92: AREA 6 DECON POND FACILITY - CAS 06-05-02: Decontamination Pond (RCRA)}

3. Waste unit cover (continued):

b. Is there evidence of cracking?

c. Is there evidence of erosion (wind or water)?

d. Is there evidence of human intrusion onto the cover?

e. Is there evidence of large animal intrusion onto the cover?

f. Is there evidence of animal burrowing?

g. Is vegetation growing on the cover?

h. Other (including trash, debris, etc within fenced area)?

4. Subsidence survey markers:

a. Have any of the five (5) subsidence survey markers been disturbed?

b. Do natural processes threaten the integrity of any subsidence survey marker?

c. Is there excessive vegetation around the subsidence survey markers?

d. Other?

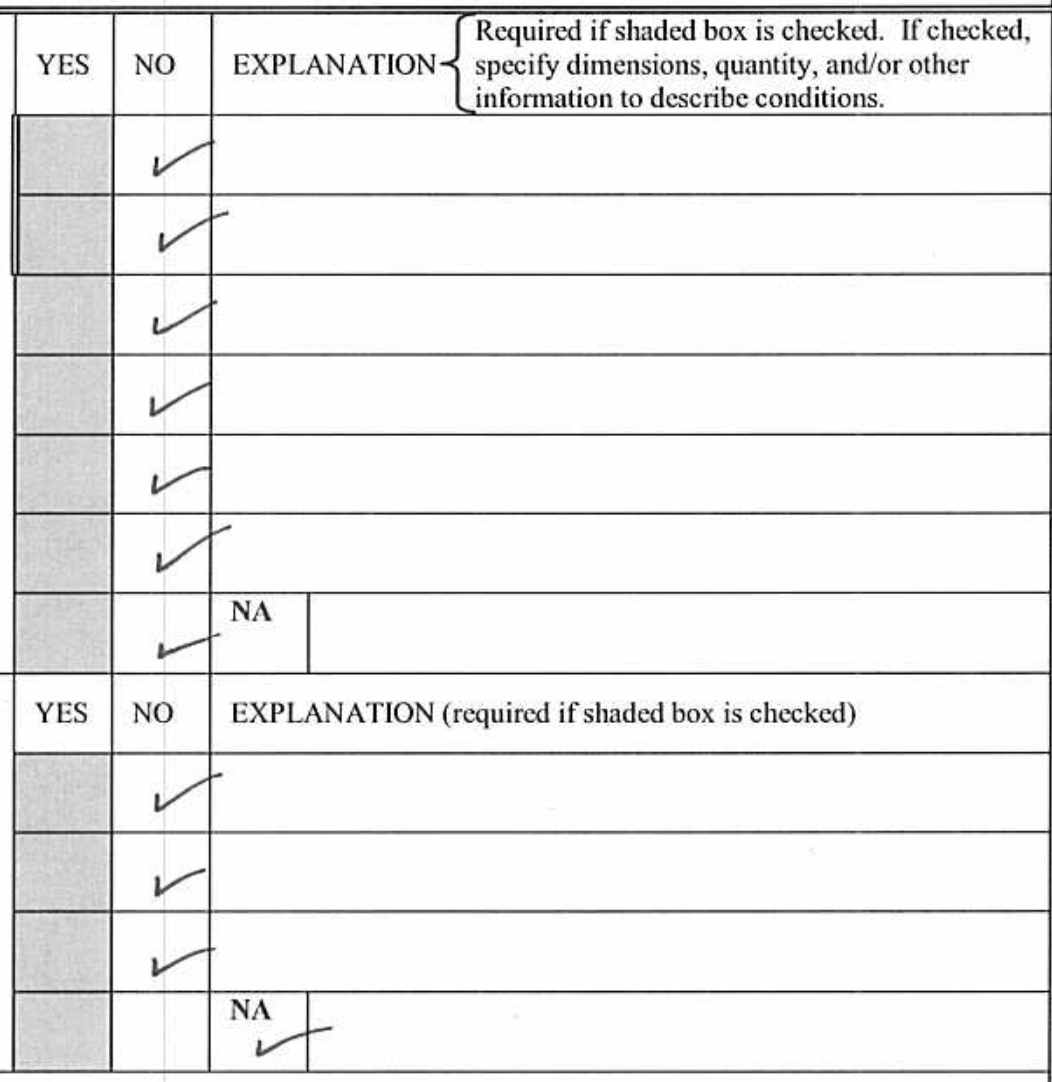

5. Photograph Instructions:

- A standard set of color photographs is required. Eight photographs must be taken during each inspection of CAU 92:

- Four (4) from the center of the unit, one in each compass direction (i.e., N, S, E, W)

- Four (4) of the unit from outside the fence, one in each compass direction (i.e., N, S, E, W).

- In addition, all anomalous features or new features (such as changes in adjacent area land use) are to be photographed.

- Additional photographs may also be taken.

- A photograph log entry will be made for each photograph taken.

6. Photograph Documentation:

a. Have all photographs been taken as required by the photograph instructions?

b. Has a photograph log been prepared?

c. How many photographs were taken?

d. Other?

\section{E. FIELD CONCLUSIONS}

1. Are more frequent inspections required?

2. Are existing maintenance/repair actions satisfactory?

3. Are general housekeeping (i.e., "minor") maintenance/repair actions needed (includes small - less than 2 inches deep cracks or settling imperfections of the cover)? [minor repairs]

\begin{tabular}{|l|l|l||}
\hline YES & NO & EXPLANATION (required if shaded box is checked) \\
\hline & & \\
\hline & & \\
\hline YES & NO & EXPLANATION (required if shaded box is checked) \\
\hline & & \\
\hline & & $\begin{array}{c}\text { If "yes", describe in Field conclusions/recommendations and the } \\
\text { Task Manager must complete the "Follow-up Actions" (not } \\
\text { part of checklist) }\end{array}$ \\
\hline
\end{tabular}


Inspection Requirements:

(1) Quarterly, or

(2) Rain Event of $>0.5$ inches in 24 hours

\section{POST-CLOSURE INSPECTION CHECKLIST}

\section{CAU 92: AREA 6 DECON POND FACILITY - CAS 06-05-02: Decontamination Pond (RCRA)}

\section{E. FIELD CONCLUSIONS (continued)}

4. Are there any deficiencies that require a remedy other than general housekeeping or small (less than 2 inches deep) cracks or settling imperfections of the cover? [i.e., more than "minor repairs"]

5. Will necessary repairs change the as-built condition of the unit?

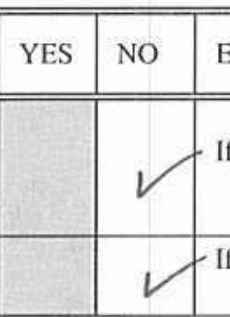

EXPLANATION (required if shaded box is checked)

If "yes", describe below and the Task Manager must complete the "Follow-up Actions" (not part of checklist)

If "yes", describe below and the Task Manager must complete the "Follow-up Actions" (not part of checklist)

6. Field conclusionsirecommendations: The chain-link fencing, UR signage, and surface grade monuments are in great condition. There is no evidence of regetation, subsidence, or settling on the cover. Standing water was noticed along the north and southwest edges, but was not seen on the actual cover. Also, the wave barriers were in excellent condition since recent repairs were completed. This site has no issues or concerns warrapting a corrective action.

\section{F. CERTIFICATION}

I have conducted an inspection of CAU 92, Area 6 Decon Pond Facility, in accordance with the procedures of the Post-Closure Permit (including the Post-Closure Plan) as recorded on this checklist, attached sheets, field notes, photographs, and photograph logs.

Chief Inspector's Signature: $/ \mathrm{S} /$ : Glenn Richardsond Date: $3 / 17 / 10$
$\begin{array}{ll}\text { Printed Name: Glenn Richardson } & \text { Title: Task Manager }\end{array}$

\section{Required Attachments:}

1. Field Notes

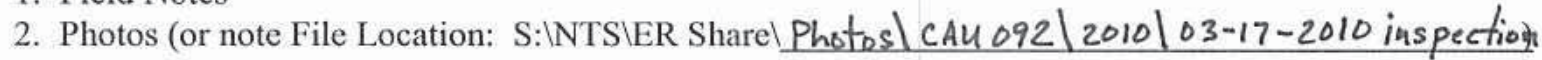

Distribution: Original - Industrial Sites Project Manager Copy - Task Manager

\section{G. VERIFICATION}

I have reviewed this checklist and attachments and have verified that it is complete.

signature: /s/: Reed Poderis Date: $4 / 20 / 10$

Printed Nam\&: Thomas A. Thiele (or designee)

Distribution: Original - Task Manager 
Inspection Requirements:

(1) Quarterly, or

(2) Rain Event of $>0.5$ inches in 24 hours

\section{POST-CLOSURE INSPECTION CHECKLIST}

\section{CAU 92: AREA 6 DECON POND FACILITY - CAS 06-05-02: Decontamination Pond (RCRA)}

\begin{tabular}{|l|l|l|}
\hline Inspection Date and Time: $6 / 23 / 10,1 / 25$ & Reason for Inspection: & Reason for Last Post-Closure Inspection: \\
\hline Date of Last Post-Closure Inspection: $3 / 17 / 10$ & Quantity of Rainfall in that event: 2.62 inches \\
\hline Date of Last Rain Event: $\quad 1 / 18 / 10$ &
\end{tabular}

Responsible Entity: NSTec Environmental Restoration, Nevada Test Site, Mercury, Nevada

Responsible Facility Owner: Thomas A. Thiele, Project Manager, Industrial Sites, Environmental Restoration Project

\begin{tabular}{|c|c|c|}
\hline 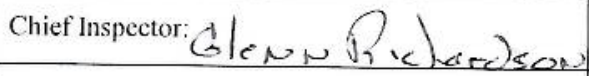 & Title:- Tosh r & Organization: Environmental Restoration \\
\hline$\rightarrow$ len Erier & Title: & Ion: Env \\
\hline
\end{tabular}

\section{A. GENERAL INSTRUCTIONS}

- Complete all checklist items.

- If a SHADED BOX is checked, provide detailed information regarding what was found and/or appropriate references to other documents that have the information (e.g., Maintenance Order Form for CAU 92 dated 2/15/2008).

- All documentation must be legible and clear.

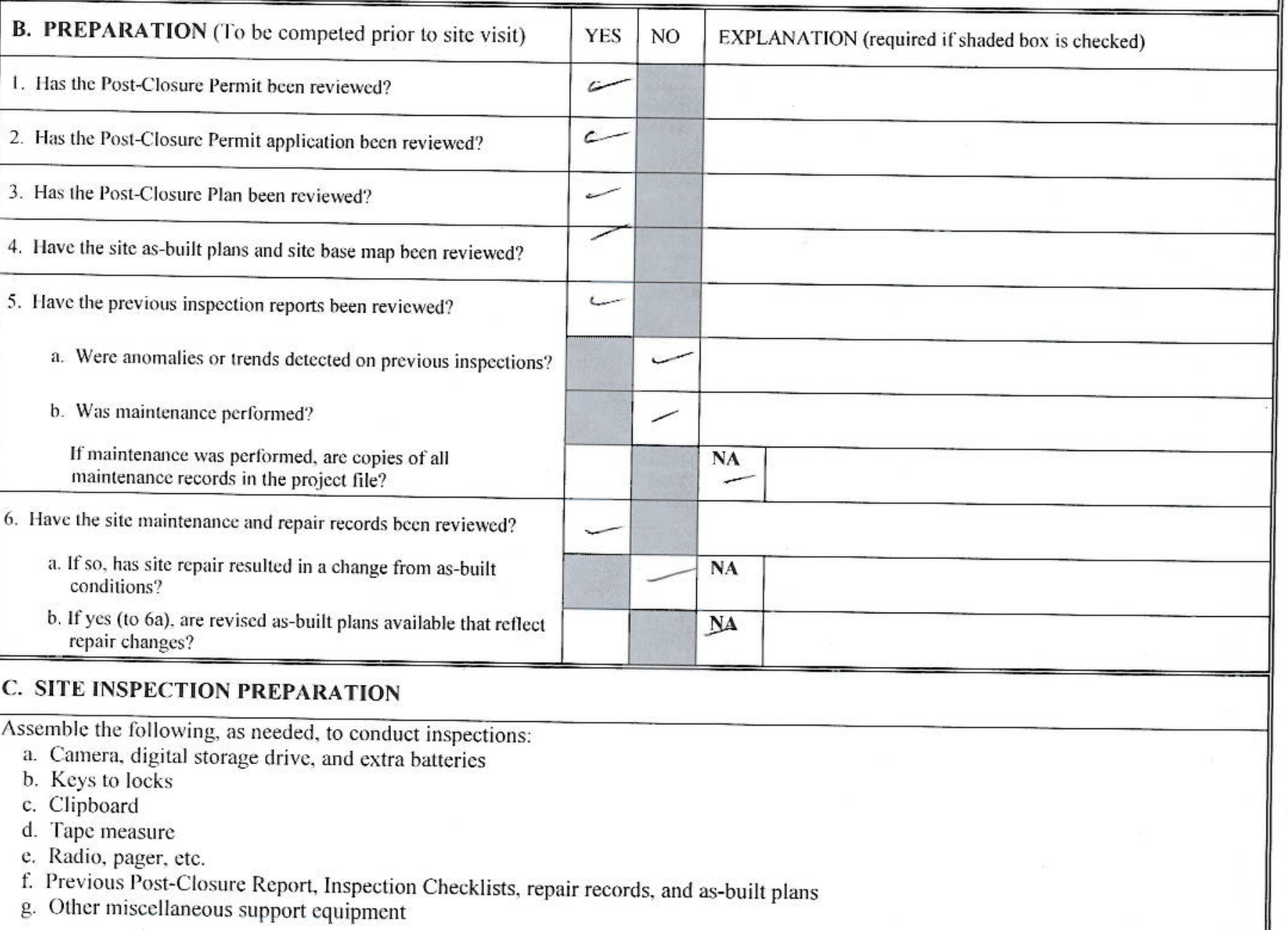


Inspection Requirements:

(1) Quarterly, or

(2) Rain Event of $>0.5$ inches in 24 hours

\section{POST-CLOSURE INSPECTION CHECKLIST}

\section{CAU 92: AREA 6 DECON POND FACILITY - CAS 06-05-02: Decontamination Pond (RCRA)}

\section{SITE INSPECTION}

- The site inspection is a walking inspection of the entire site including the perimeter and sufficient transects to be able to inspect the entire surface and all features specifically described in this checklist. The checklist should be completed during the site inspection.

- If a shaded box is checked, add detailed comments to document the results of the site inspection. Information provided should be of sufficient detail to enable reconstruction of observations regarding field conditions. Information can take the form of written narrative, sketches, measurements, and annotated site maps, all of which should be placed on additional attachments (if needed) and cross-reference appropriately. Attach the additional pages and number all pages upon completion of the inspection. The completed checklist is part of the field record of the inspection.

- Field notes taken to assist in completion of this checklist will become part of the inspection record. No form is specified for field notes, and additional field notes are not required if the checklist and associated attachments adequately describe site conditions.

1. Adjacent off-site features:

a. Are there any new activities or features on Yucca Lake that could potentially affect the site (e.g., activities that change the flow of surface water or are encroaching the unit)?

2. Fencing, gates, and signs:

a. Is there damage to or a break in the fence?

b. Have any fence posts been damaged or their anchoring weakened?

c. Are any of the use restriction signs damaged or missing?

d. Are all use restriction signs legible?

e. How many use restriction signs need to be replaced?

f. Are any of the URMA signs damaged or missing?

g. Are all URMA signs legible?

h. How many URMA signs need to be replaced?

i. Is the gate intact and functional?

j. Does the gate show evidence of tampering or damage?

k. Was the gate locked?

1. Does the wave barrier require repair?

$\mathrm{m}$. Is there standing water within or at the fenceline?

If yes, what is the playa water elevation, as measured on the depth gauge attached to the fence perimeter?

n. Other?

3. Waste unit cover:

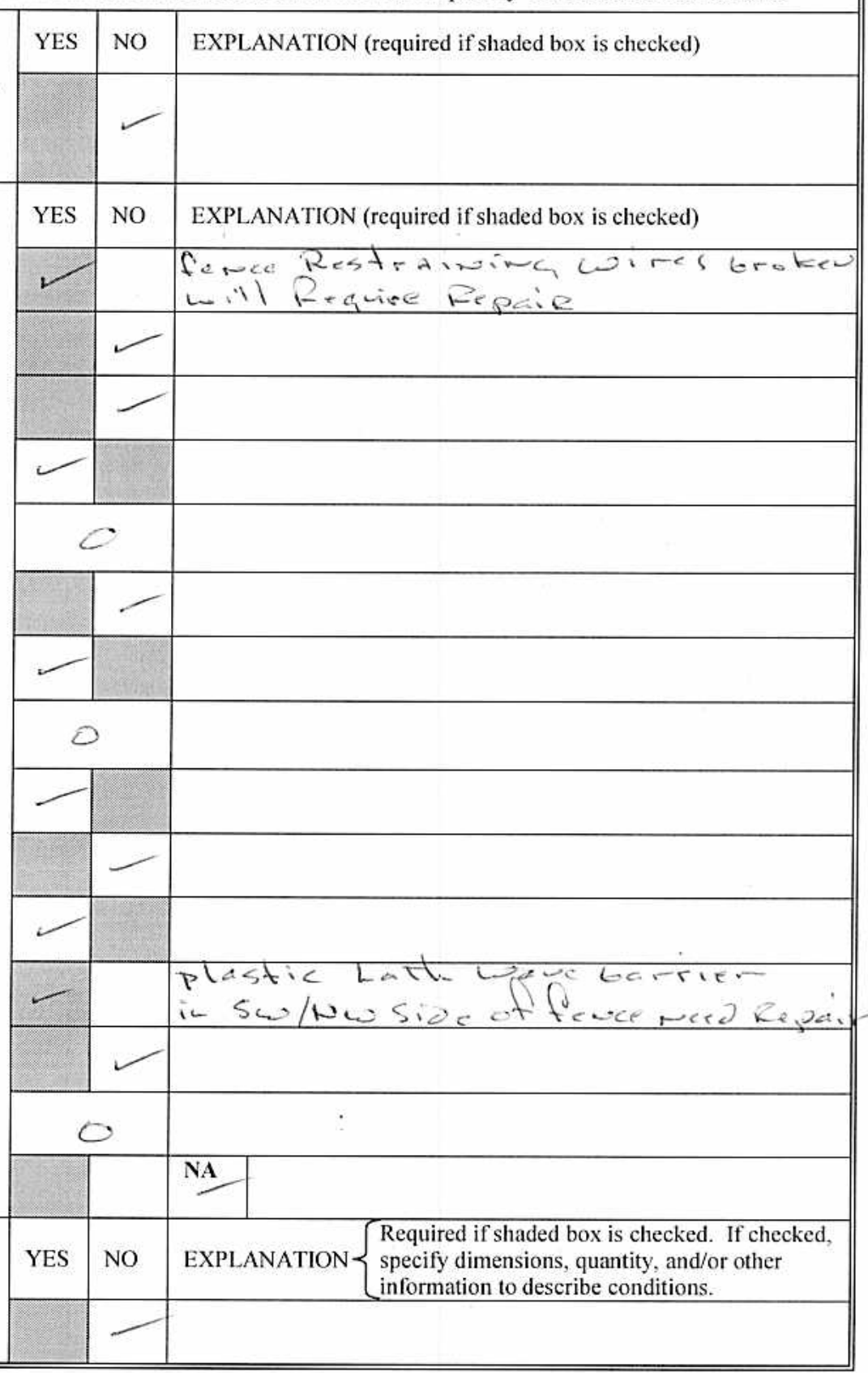

a. Is there evidence of settling? 
Inspection Requirements:

(1) Quarterly, or

(2) Rain Event of $>0.5$ inches in 24 hours

\section{POST-CLOSURE INSPECTION CHECKLIST}

\section{CAU 92: AREA 6 DECON POND FACILITY - CAS 06-05-02: Decontamination Pond (RCRA)}

3. Waste unit cover (continued):

b. Is there evidence of cracking?

c. Is there evidence of erosion (wind or water)?

d. Is there evidence of human intrusion onto the cover?

e. Is there evidence of large animal intrusion onto the cover?

f. Is there evidence of animal burrowing?

g. Is vegetation growing on the cover?

h. Other (including trash, debris, etc within fenced area)?

4. Subsidence survey markers:

a. Have any of the five (5) subsidence survey markers been disturbed?

b. Do natural processes threaten the integrity of any subsidence survey marker?

c. Is there excessive vegetation around the subsidence survey markers?

d. Other?

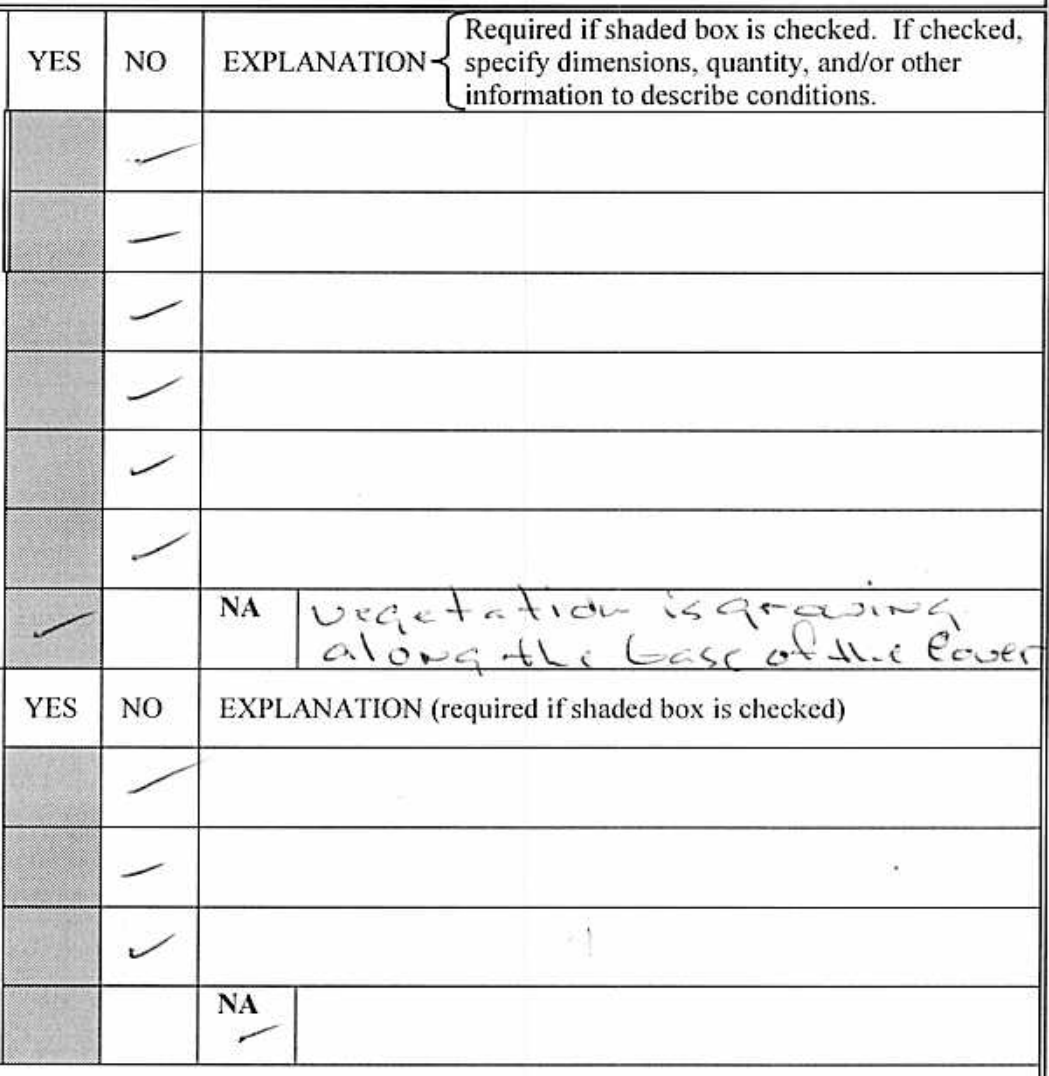

5. Photograph Instructions:

- A standard set of color photographs is required. Eight photographs must be taken during each inspection of CAU 92:

- Four (4) from the center of the unit, one in each compass direction (i.e., N, S, E, W)

- Four (4) of the unit from outside the fence, one in each compass direction (i.c., N, S, E, W).

- In addition, all anomalous features or new features (such as changes in adjacent area land use) are to be photographed.

- Additional photographs may also be taken.

- A photograph log entry will be made for each photograph taken.

6. Photograph Documentation:

a. Have all photographs been taken as required by the photograph instructions?

b. Has a photograph log been prepared?

c. How many photographs were taken?

d. Other?

\begin{tabular}{|c|c|c|c|}
\hline E. FIELD CONCLUSIONS & YES & NO & EXPLANATION (required if shaded box is checked) \\
\hline 1. Are more frequent inspections required? & & & \\
\hline 2. Are existing maintenance/repair actions satisfactory? & & & \\
\hline $\begin{array}{l}\text { 3. Are general housekeeping (i.e., "minor") maintenance/repair } \\
\text { actions needed (includes small - less than } 2 \text { inches deep - } \\
\text { cracks or settling imperfections of the cover)? [minor repairs] }\end{array}$ & & & $\begin{array}{l}\text { If "yes", describe in Field conclusions/recommendations and the } \\
\text { Task Manager must complete the "Follow-up Actions" (not } \\
\text { part of checklist) }\end{array}$ \\
\hline
\end{tabular}


Inspection Requirements:

(1) Quarterly, or

(2) Rain Event of $>0.5$ inches in 24 hours

\section{POST-CLOSURE INSPECTION CHECKLIST}

\section{CAU 92: AREA 6 DECON POND FACILITY - CAS 06-05-02: Decontamination Pond (RCRA)}

\begin{tabular}{||l|l|l|l|}
\hline \hline E. FIELD CONCLUSIONS (continued) & YES & NO & EXPLANATION (required if shaded box is checked) \\
\hline \hline $\begin{array}{l}\text { 4. Are there any deficiencies that require a remedy other than } \\
\text { general housekeeping or small (less than 2 inches deep) cracks } \\
\text { or settling imperfections of the cover? [i.e., more than } \\
\text { "minor repairs"] }\end{array}$ & If "yes", describe below and the Task Manager must complete the \\
\hline "Follow-up Actions" (not part of checklist)
\end{tabular}

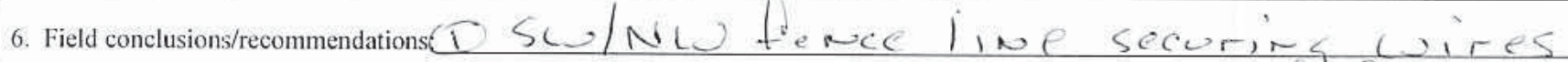
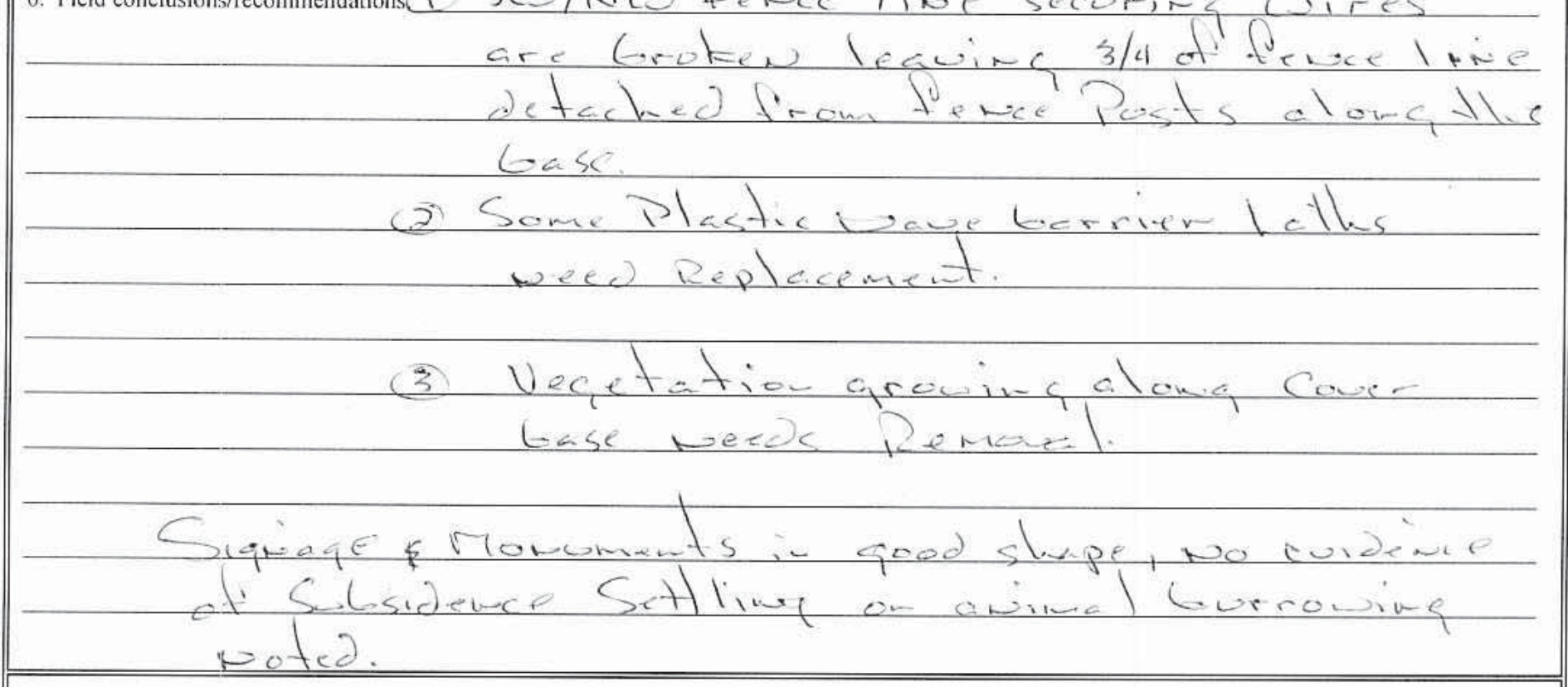

\section{F. CERTIFICATION}

I have conducted an inspection of CAU 92, Area 6 Decon Pond Facility, in accordance with the procedures of the Post-Closure Permit (including the Post-Closure Plan) as recorded on this checklist, attached sheets, field notes, photographs, and photograph logs.

Chief Inspector's Signature/s/: Glenn Richardson Date:

Printed Name: Glenn Pichardson

Title:

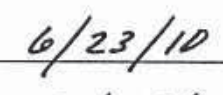

Task Manager

\section{Required Attachments:}

1. Field Notes

2. Photos (or note File Location: S:INTS ER Sharel Photos CAu 092 | 2010 $06-23-2010$ Inspections

Distribution: Original - Industrial Sites Project Manager

Copy - Task Manager

\section{G. VERIFICATION}

I have reviewed thischecklist and attachments and have verified that it is complete.

Signature: /s/: Reed Poderis

Printed Name: Thom 5 A. Thiele (ot designee)

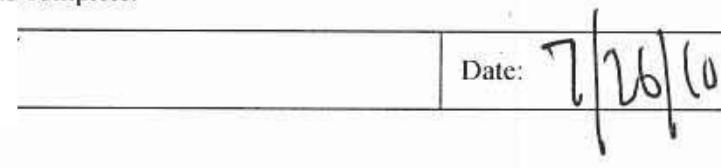

Distribution: Original - Task Manager 
Inspection Requirements:

(1) Quarterly, or

(2) Rain Event of $>0.5$ inches in 24 hours

\section{POST-CLOSURE INSPECTION CHECKLIST}

\section{CAU 92: AREA 6 DECON POND FACILITY - CAS 06-05-02: Decontamination Pond (RCRA)}

\begin{tabular}{|c|c|c|c|}
\hline \multirow{2}{*}{\multicolumn{2}{|c|}{$\begin{array}{ll}\text { Inspection Date and Time: } 4 / 8 / 10 & 11: 40 \mathrm{AM}\end{array}$}} & \multicolumn{2}{|c|}{ Reason for Inspection: Quarterly } \\
\hline & & \multicolumn{2}{|c|}{ Reason for Last Post-Closure Inspection: Quarterly } \\
\hline Date of Last Rain Event: & & \multicolumn{2}{|c|}{ Quantity of Rainfall in that event: 2.62 inches } \\
\hline \multicolumn{4}{|c|}{ Responsible Entity: NSTec Environmental Restoration, Nevada Test Site, Mercury, Nevada } \\
\hline \multicolumn{4}{|c|}{ Responsible Facility Owner: Thomas A. Thiele, Project Manager, Industrial Sites, Environmental Restoration Project } \\
\hline Chief Inspector: Glenn Richardson & Title: 7 & Lanager & Organization: Environmental Restoration \\
\hline Assistant Inspector: & Title: & & Organization: Environmental Restoration \\
\hline
\end{tabular}

A. GENERAL INSTRUCTIONS

- Complete all checklist items.

- If a SHADED BOX is checked, provide detailed information regarding what was found and/or appropriate references to other documents that have the information (e.g., Maintenance Order Form for CAU 92 dated 2/15/2008).

- All documentation must be legible and clear.

B. PREPARATION (To be competed prior to site visit)

1. Has the Post-Closure Permit been reviewed?

2. Has the Post-Closure Permit application been reviewed?

3. Has the Post-Closure Plan been reviewed?

4. Have the site as-built plans and site base map been reviewed?

5. Have the previous inspection reports been reviewed?

a. Were anomalies or trends detected on previous inspections?

b. Was maintenance performed?

If maintenance was performed, are copies of all maintenance records in the project file?

6. Have the site maintenance and repair records been reviewed?

a. If so, has site repair resulted in a change from as-built conditions?

b. If yes (to $6 a$ ), are revised as-built plans available that reflect repair changes?

\begin{tabular}{|l|l|l||}
\hline YES & NO & EXPLANATION (required if shaded box is checked) \\
\hline & & \\
\hline
\end{tabular}

\section{SITE INSPECTION PREPARATION}

Assemble the following, as needed, to conduct inspections:
a. Camera, digital storage drive, and extra batteries
b. Keys to locks
c. Clipboard
d. Tape measure
e. Radio, pager, etc.
f. Previous Post-Closure Report, Inspection Checklists, repair records, and as-built plans
g. Other miscellaneous support equipment 
Inspection Requirements:

(1) Quarterly, or

(2) Rain Event of $>0.5$ inches in 24 hours

\section{POST-CLOSURE INSPECTION CHECKLIST}

\section{CAU 92: AREA 6 DECON POND FACILITY - CAS 06-05-02: Decontamination Pond (RCRA)}

\section{SITE INSPECTION}

- The site inspection is a walking inspection of the entire site including the perimeter and sufficient transects to be able to inspect the entire surface and all features specifically described in this checklist. The checklist should be completed during the site inspection.

- If a shaded box is checked, add detailed comments to document the results of the site inspection. Information provided should be of sufficient detail to enable reconstruction of observations regarding field conditions. Information can take the form of written narrative, sketches, measurements, and annotated site maps, all of which should be placed on additional attachments (if needed) and cross-reference appropriately. Attach the additional pages and number all pages upon completion of the inspection. The completed checklist is part of the field record of the inspection.

- Field notes taken to assist in completion of this checklist will become part of the inspection record. No form is specified for field notes, and additional field notes are not required if the checklist and associated attachments adequately describe site conditions.

1. Adjacent off-site features:

a. Are there any new activities or features on Yucca Lake that could potentially affect the site (e.g., activities that change the flow of surface water or are encroaching the unit)?

2. Fencing, gates, and signs:

a. Is there damage to or a break in the fence?

b. Have any fence posts been damaged or their anchoring weakened?

c. Are any of the use restriction signs damaged or missing?

d. Are all use restriction signs legible?

e. How many use restriction signs need to be replaced?

f. Are any of the URMA signs damaged or missing?

g. Are all URMA signs legible?

h. How many URMA signs need to be replaced?

i. Is the gate intact and functional?

j. Does the gate show evidence of tampering or damage?

k. Was the gate locked?

1. Does the wave barrier require repair?

$\mathrm{m}$. Is there standing water within or at the fenceline?

If yes, what is the playa water elevation, as measured on the depth gauge attached to the fence perimeter?

n. Other?

3. Waste unit cover:

a. Is there evidence of settling?

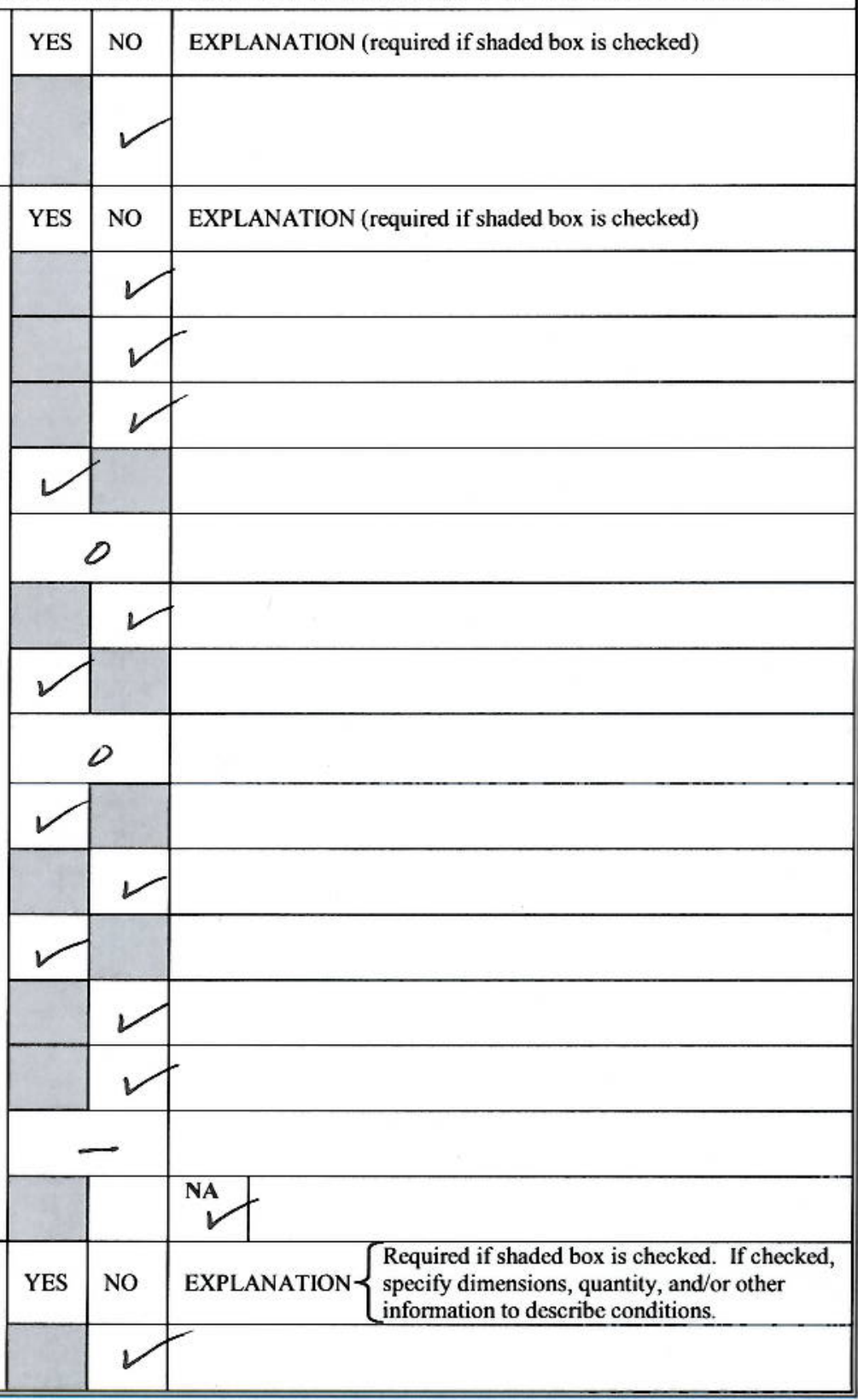


Inspection Requirements:

(1) Quarterly, or

(2) Rain Event of $>0.5$ inches in 24 hours

\section{POST-CLOSURE INSPECTION CHECKLIST}

\section{CAU 92: AREA 6 DECON POND FACILITY - CAS 06-05-02: Decontamination Pond (RCRA)}

3. Waste unit cover (continued):

b. Is there evidence of cracking?

c. Is there evidence of erosion (wind or water)?

d. Is there evidence of human intrusion onto the cover?

e. Is there evidence of large animal intrusion onto the cover?

f. Is there evidence of animal burrowing?

g. Is vegetation growing on the cover?

h. Other (including trash, debris, etc within fenced area)?

4. Subsidence survey markers:

a. Have any of the five (5) subsidence survey markers been disturbed?

b. Do natural processes threaten the integrity of any subsidence survey marker?

c. Is there excessive vegetation around the subsidence survey markers?

d. Other?

\begin{tabular}{|c|c|c|}
\hline YES & NO & EXPLANATION $\left\{\begin{array}{l}\text { Required if shaded box is checked. If checked, } \\
\text { specify dimensions, quantity, and/or other } \\
\text { information to describe conditions. }\end{array}\right.$ \\
\hline & & \\
\hline & & \\
\hline & & \\
\hline & & \\
\hline & & \\
\hline$V$ & & $\begin{array}{l}\text { New vegetation was noticed sprouting along } \\
\text { the south edge of the cover. }\end{array}$ \\
\hline & & NA \\
\hline YES & No & EXPLANATION (required if shaded box is checked) \\
\hline & & \\
\hline & 2 & \\
\hline & $V$ & \\
\hline & & NA \\
\hline
\end{tabular}

5. Photograph Instructions:

- A standard set of color photographs is required. Eight photographs must be taken during each inspection of CAU 92:

- Four (4) from the center of the unit, one in each compass direction (i.e., N, S, E, W)

- Four (4) of the unit from outside the fence, one in each compass direction (i.e., N, S, E, W).

- In addition, all anomalous features or new features (such as changes in adjacent area land use) are to be photographed.

- Additional photographs may also be taken.

- A photograph log entry will be made for each photograph taken.

6. Photograph Documentation:

a. Have all photographs been taken as required by the photograph instructions?

b. Has a photograph log been prepared?

c. How many photographs were taken?

d. Other?

\section{E. FIELD CONCLUSIONS}

1. Are more frequent inspections required?

2. Are existing maintenance/repair actions satisfactory?

3. Are general housekeeping (i.e., "minor") maintenance/repair actions needed (includes small - less than 2 inches deep cracks or settling imperfections of the cover)? [minor repairs]

\begin{tabular}{|l|l|l|}
\hline YES & NO & EXPLANATION (required if shaded box is checked) \\
\hline & & \\
\hline YES & NO & EXPLANATION (required if shaded box is checked) \\
\hline & & \\
\hline & & $\begin{array}{c}\text { If "yes", describe in Field conclusions/recommendations and the } \\
\text { Task Manager must complete the "Follow-up Actions" (not } \\
\text { part of checklist) }\end{array}$ \\
\hline
\end{tabular}


Inspection Requirements:

(1) Quarterly, or

(2) Rain Event of $>0.5$ inches in 24 hours

\section{POST-CLOSURE INSPECTION CHECKLIST}

\section{CAU 92: AREA 6 DECON POND FACILITY - CAS 06-05-02: Decontamination Pond (RCRA)}

\section{E. FIELD CONCLUSIONS (continued)}

4. Are there any deficiencies that require a remedy other than general housekeeping or small (less than 2 inches deep) cracks or settling imperfections of the cover? [i.e., more than "minor repairs"]

5. Will necessary repairs change the as-built condition of the unit?

\section{\begin{tabular}{l|l} 
YES & NO \\
\hline
\end{tabular}}

If "yes", describe below and the Task Manager must complete the "Follow-up Actions" (not part of checklist)

If "yes", describe below and the Task Manager must complete the "Follow-up Actions" (not part of checklist)

6. Field conclusions/recommendations: The UR signage and radiological postings are intact and legible. There is no evidence of anima/ burrowing, settling, or subsidence. The surface grade monuments are in good condition. Vegetation was noticed sprouting aloug the south edge of the cover: Vegetation removal and/or herbicide application is necessary as a corrective action. The chain-link fence is in great condition and the repairs that were completed in Angust 2010 are well-maintained.

\section{F. CERTIFICATION}

I have conducted an inspection of CAU 92, Area 6 Decon Pond Facility, in accordance with the procedures of the Post-Closure Permit (including the Post-Closure Plan) as recorded on this checklist, attached sheets, field notes, photographs, and photograph logs.

chief Inspector's signatu/s/: Glenn Richârdson Date: $9 / 8 / 10$

Printed Name: Glemn Richardson Title: Task Manager

\section{Required Attachments:}

1. Field Notes

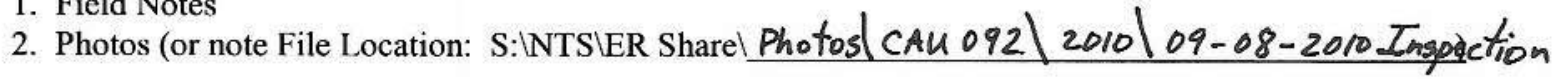

Distribution: Original - Industrial Sites Project Manager

Copy - Task Manager

\section{G. VERIFICATION}

I have reviewed this choplitist and attachments and have verified that it is complete.

Signature: /s/: Reed Poderis

Printed Name: Thomas A. Thiele (dedesignee)

Distribution: Original - Task Manager 
RCRA Post-Closure Report

Revision: 0

Date: January 2011

\section{CORRECTIVE ACTION UNIT 110 INSPECTION CHECKLISTS}


RCRA Post-Closure Report

Revision: 0

Date: January 2011

\section{THIS PAGE INTENTIONALLY LEFT BLANK}




\begin{tabular}{|c|c|c|c|c|c|}
\hline \multicolumn{6}{|c|}{ POST-CLOSURE INSPECTION CHECKLIST } \\
\hline \multicolumn{6}{|c|}{ CAU 110: AREA 3 WMD U-3ax/bl CRATER - CAS 03-23-04: U-3axbl Subsidence Crater } \\
\hline \multicolumn{3}{|c|}{ Inspection Date and Time: $\quad 12 / 15 / 09 \quad 10: 15 \mathrm{AM}$} & \multicolumn{3}{|c|}{ Reason for Inspection: Quarterly } \\
\hline \multicolumn{3}{|c|}{ Date of Last Post-Closure Inspection: $\quad 9 / 23 / 09$} & \multicolumn{3}{|c|}{ Reason for Last Post-Closure Inspection: Quarterly } \\
\hline \multicolumn{6}{|c|}{ Responsible Entity: NSTec Environmental Restoration, Nevada Test Site, Mercury, Nevada } \\
\hline \multicolumn{6}{|c|}{ Responsible Facility Owner: Thomas A. Thiele, Project Manager, Industrial Sites, Environmental Restoration Project } \\
\hline Chief Inspector: Glenn Richardson & \multicolumn{4}{|c|}{ Title: Task Manager } & Organization: Environmental Restoration \\
\hline Assistant Inspector: Greq Doyle & \multicolumn{4}{|c|}{ Title: Sr. Scientist } & Organization: Environmental Restoration \\
\hline \multicolumn{6}{|c|}{$\begin{array}{l}\text { A. GENERAL INSTRUCTIONS } \\
\text { - Complete all checklist items. } \\
\text { - If a SHADED BOX is checked, provide detailed information regarding what was found and/or appropriate references } \\
\text { to other documents that have the information (e.g., Maintenance Order Form for CAU } 91 \text { dated } 2 / 15 / 2008 \text { ). } \\
\text { - All documentation must be legible and clear. }\end{array}$} \\
\hline \multicolumn{2}{|c|}{ B. PREPARATION (To be competed prior to site visit) } & YES & NO & \multicolumn{2}{|c|}{ EXPLANATION (required if shaded box is checked) } \\
\hline \multicolumn{6}{|l|}{ 1. Has the Post-Closure Permit been reviewed? } \\
\hline \multicolumn{2}{|c|}{ 2. Has the Post-Closure Permit application been reviewed? } & & & & \\
\hline \multicolumn{2}{|l|}{ 3. Has the Post-Closure Plan been reviewed? } & & & & \\
\hline \multicolumn{2}{|c|}{ 4. Have the site as-built plans and site base map been reviewed? } & & & & \\
\hline \multicolumn{2}{|l|}{ 5. Have the previous inspection reports been reviewed? } & & & & \\
\hline \multirow{2}{*}{\multicolumn{2}{|c|}{$\begin{array}{l}\text { a. Were anomalies or trends detected on previous inspections? } \\
\text { b. Was maintenance performed? }\end{array}$}} & & & & \\
\hline & & $v$ & & & tenance was completed on \\
\hline \multicolumn{2}{|c|}{ 6. Have the site maintenance and repair records been reviewed? } & & & & \\
\hline \multicolumn{2}{|c|}{$\begin{array}{l}\text { a. If so, has site repair resulted in a change from as-built } \\
\text { conditions? }\end{array}$} & & & NA & \\
\hline \multicolumn{2}{|c|}{$\begin{array}{l}\text { b. If yes (to } 6 \mathrm{a}) \text {, are revised as-built plans available that reflect } \\
\text { repair changes? }\end{array}$} & & & & \\
\hline \multicolumn{6}{|l|}{ C. SITE INSPECTION PREPARATION } \\
\hline \multicolumn{6}{|l|}{$\begin{array}{l}\text { Assemble the following, as needed, to conduct } \\
\text { a. Camera, digital storage drive, and extra ba } \\
\text { b. Keys to locks } \\
\text { c. Clipboard } \\
\text { d. Tape measure } \\
\text { e. Radio, pager, etc. } \\
\text { f. Previous Post-Closure Report, Inspection } \\
\text { g. Other miscellaneous support equipment }\end{array}$} \\
\hline
\end{tabular}




\section{POST-CLOSURE INSPECTION CHECKLIST}

\section{CAU 110: AREA 3 WMD U-3ax/bl CRATER - CAS 03-23-04: U-3axbl Subsidence Crater}

\section{SITE INSPECTION}

- The site inspection is a walking inspection of the entire site including the perimeter and sufficient transects to be able to inspect the entire surface and all features specifically described in this checklist. The checklist should be completed during the site inspection.

- If a shaded box is checked, add detailed comments to document the results of the site inspection. Information provided should be of sufficient detail to enable reconstruction of observations regarding field conditions. Information can take the form of written narrative, sketches, measurements, and annotated site maps, all of which should be placed on additional attachments (if needed) and cross-reference appropriately. Attach the additional pages and number all pages upon completion of the inspection. The completed checklist is part of the field record of the inspection.

- Field notes taken to assist in completion of this checklist will become part of the inspection record. No form is specified for field notes, and additional field notes are not required if the checklist and associated attachments adequately describe site conditions.

1. Adjacent off-site features:

a. Are there any new activities or features in the vicinity that could potentially affect the site (e.g., activities that change the flow of surface water or are encroaching the unit)?

2. Fences, gates, and signs:

a. Is there damage to or a break in the fence?

b. Is there damage to or a break in the chicken wire fence?

c. Have any fenceposts been damaged or their anchoring weakened?

d. Is the gate intact and functional?

e. Does the gate show evidence of tampering or damage?

f. Was the gate locked?

g. Are any of the use restriction signs damaged or missing?

h. Are all use restriction signs legible?

i. How many use restriction signs need to be replaced?

3. Waste unit cover (Western portion, "ax"):

a. Is there evidence of settling?

b. Is there evidence of cracking?

c. Is there evidence of erosion (wind or water)?

d. Is there evidence of human intrusion onto the cover?

e. Is there evidence of large animal intrusion onto the cover?

f. Is there evidence of animal burrowing?

g. Is there a change or difference in vegetation (i.e., is the vegetation growing on the cover inconsistent with the naturally-occurring vegetation growing outside of the unit)?

h. Other (including trash, debris, etc within fenced area)?

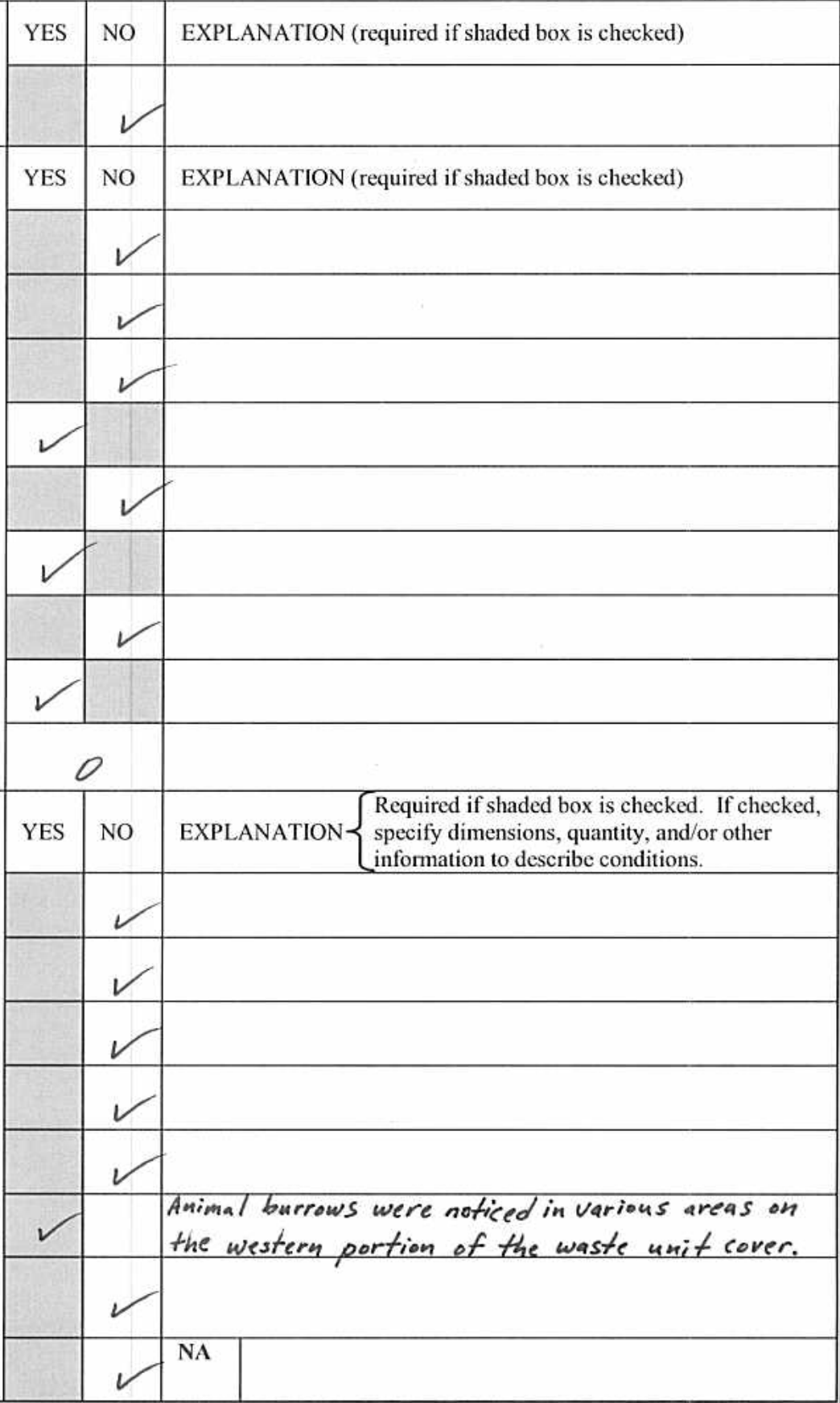




\section{POST-CLOSURE INSPECTION CHECKLIST}

\section{CAU 110: AREA 3 WMD U-3ax/bl CRATER - CAS 03-23-04: U-3axbl Subsidence Crater}

4. Waste unit cover (Eastern portion, "bl"):

a. Is there evidence of settling?

b. Is there evidence of cracking?

c. Is there evidence of erosion (wind or water)?

d. Is there evidence of human intrusion onto the cover?

e. Is there evidence of large animal intrusion onto the cover?

f. Is there evidence of animal burrowing?

g. Is there a change or difference in vegetation (i.e., is the vegetation growing on the cover inconsistent with the naturally-occurring vegetation growing outside of the unit)?

h. Other (including trash, debris, etc within fenced area)?

5. Subsidence survey markers and TDR Probes:

a. Have any of the seven (7) subsidence survey markers been disturbed?

b. Do natural processes threaten the integrity of any subsidence survey marker?

c. Is there excessive vegetation around the subsidence survey markers?

d. Is there any evidence that TDR probes have been disturbed or the wires damaged?

e. Other?

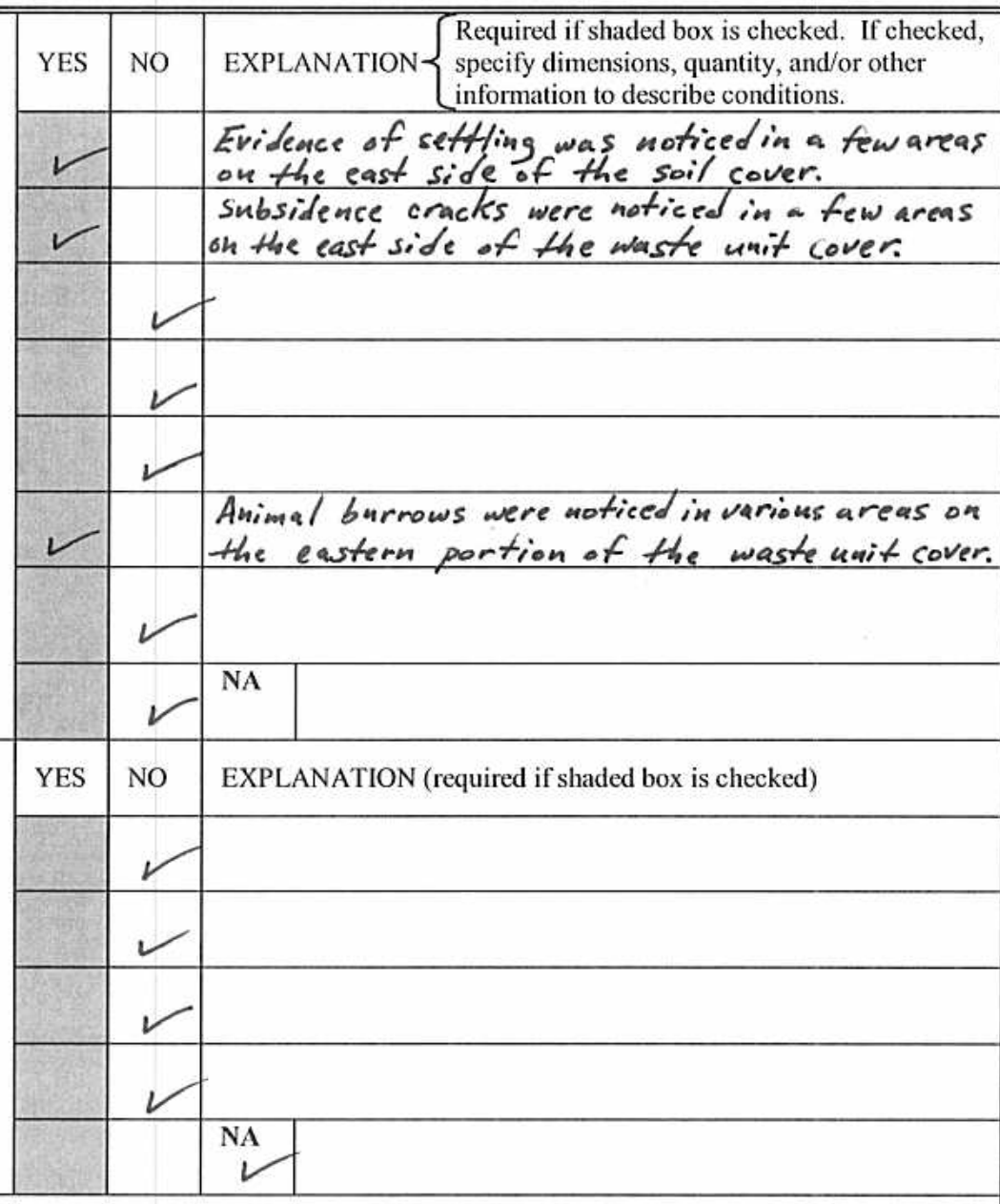

6. Photograph Instructions:

- A standard set of eight (8) color photographs is required to be taken during each inspection of CAU 110:

- Four (4) from the center of the unit, one in each compass direction (i.e., N, S, E, W)

- Four (4) of the unit from outside the fence, one in each compass direction (i.e., N, S, E, W).

- In addition, all anomalous features or new features (such as changes in adjacent area land use) are to be photographed.

- Additional photographs may also be taken.

- A photograph log entry will be made for each photograph taken.

7. Photograph Documentation:

a. Have all photographs been taken as required by the photograph instructions?

b. Has a photograph log been prepared?

c. How many photographs were taken?

d. Other?

\begin{tabular}{|l|l|l||}
\hline YES & NO & EXPLANATION (required if shaded box is checked) \\
\hline & & \multicolumn{1}{|l|}{} \\
\hline YES & NO & EXPLANATION (required if shaded box is checked) \\
\hline & & \\
\hline
\end{tabular}

2. Are existing maintenance/repair actions satisfactory? 


\section{POST-CLOSURE INSPECTION CHECKLIST}

\section{CAU 110: AREA 3 WMD U-3ax/bl CRATER - CAS 03-23-04: U-3axbl Subsidence Crater}

\begin{tabular}{||l|l|l|l|}
\hline \hline E. FIELD CONCLUSIONS (continued) & YES & NO & EXPLANATION (required if shaded box is checked) \\
\hline $\begin{array}{l}\text { 3. Are general housekeeping (i.e., "minor") maintenance/repair } \\
\text { actions needed (includes cracks or settling imperfections less } \\
\text { than 6 inches deep that extend less than 3 feet on the cover)? } \\
\text { [minor repairs] }\end{array}$ & If "yes", describe in Field conclusions/recommendations \\
$\begin{array}{l}\text { general housekeeping or small (less than 6 inches deep and 3 } \\
\text { feet long) cracks or settling imperfections of the cover? [i.e., } \\
\text { more than "minor repairs"] }\end{array}$ & If "yes", describe below and the Task Manager must complete the \\
\hline "Follow-up Actions" (not part of checklist)
\end{tabular}

6. Field conclusions/recommendations: The UR signage, radiological signage, and fencing were in great condition. The vegetation on the cover appears to be well established and stable contributing from more favorable growing conditions. Noticed a few animal burrows in various areas on the west and east sections of the waste nuit cover. In addition, subsidence and settling imperfections (cracks) greater than bin. deep that exteuded from a range of $3-8 \mathrm{ft}$ in different areas aloug the Fast edge of the cover. Subsidence repairs are necessary withier bo days, Also, with excess borrow soil, the animal burrows will be bactifilled.

\section{F. CERTIFICATION}

I have conducted an inspection of CAU 110, Area 3 WMD U-3ax/bl Crater, in accordance with the procedures of the Post-Closure Permit (including the Post-Closure Plan) as recorded on this checklist, attached sheets, field notes, photographs, and photograph logs.

Chief Inspector's signature/s/: Glenn Richardson Date:

Printed Name: Glenn Fichardson

\section{Required Attachments:}

1. Field Notes

2. Photos (or note File Location: S: NTS\ER Share Photos $\mid$ cAu $110 \backslash 2009 \backslash 12-15-2009$ cAu 110 Inspedtion

Distribution: Original - Industrial Sites Project Manager

Copy - Task Manager

\section{G. VERIFICATION}

I have reviewe $/$ /pis checklist and attachments and have verified that it is complete.

Signatur: $/ \mathrm{s} /$ : Reed Poderis

Date: $12 / 212009$

Printed Name:(Thomas A. Thiele (or designee)

Distribution: Original - Task Manager 


\begin{tabular}{|c|c|c|c|c|c|}
\hline \multicolumn{6}{|c|}{ POST-CLOSURE INSPECTION CHECKLIST } \\
\hline \multicolumn{6}{|c|}{ CAU 110: AREA 3 WMD U-3ax/bl CRATER - CAS 03-23-04: U-3axbl Subsidence Crater } \\
\hline \multicolumn{3}{|c|}{ Inspection Date and Time: $\quad 3 / 17 / 10 \quad 10.45 \mathrm{AM}$} & \multicolumn{3}{|c|}{ Reason for Inspection: Quarterly } \\
\hline \multicolumn{3}{|c|}{ Date of Last Post-Closure Inspection: $12 / 15 / 09$} & \multicolumn{3}{|c|}{ Reason for Last Post-Closure Inspection: Quarter/y } \\
\hline \multicolumn{6}{|c|}{ Responsible Entity: NSTec Environmental Restoration, Nevada Test Site, Mercury, Nevada } \\
\hline \multicolumn{6}{|c|}{ Responsible Facility Owner: Thomas A. Thiele, Project Manager, Industrial Sites, Environmental Restoration Project } \\
\hline Chief Inspector: Gleun Richardson & \multicolumn{4}{|c|}{ Title: Task Manager } & Organization: Environmental Restoration \\
\hline Assistant Inspector: Dudley Emer & \multicolumn{4}{|c|}{ Title: Sr. Scientist } & Organization: Environmental Restoration \\
\hline \multicolumn{6}{|c|}{$\begin{array}{l}\text { A. GENERAL INSTRUCTIONS } \\
\text { - Complete all checklist items. } \\
\text { - If a SHADED BOX is checked, provide detailed information regarding what was found and/or appropriate references } \\
\text { to other documents that have the information (e.g., Maintenance Order Form for CAU } 91 \text { dated } 2 / 15 / 2008 \text { ). } \\
\text { - All documentation must be legible and clear. }\end{array}$} \\
\hline \multicolumn{2}{|c|}{ B. PREPARATION (To be competed prior to site visit) } & YES & NO & \multicolumn{2}{|c|}{ EXPLANATION (required if shaded box is checked) } \\
\hline \multicolumn{2}{|l|}{ 1. Has the Post-Closure Permit been reviewed? } & & & & \\
\hline \multicolumn{2}{|c|}{ 2. Has the Post-Closure Permit application been reviewed? } & & & & \\
\hline \multicolumn{2}{|l|}{ 3. Has the Post-Closure Plan been reviewed? } & & & & \\
\hline \multicolumn{2}{|c|}{ 4. Have the site as-built plans and site base map been reviewed? } & & & & \\
\hline \multicolumn{2}{|c|}{ 5. Have the previous inspection reports been reviewed? } & & & & \\
\hline \multirow{2}{*}{\multicolumn{2}{|c|}{$\begin{array}{l}\text { a. Were anomalies or trends detected on previous inspections? } \\
\text { b. Was maintenance performed? }\end{array}$}} & & & & \\
\hline & & $\checkmark$ & & $\begin{array}{l}\text { Subsic } \\
\text { in } \sqrt{a}\end{array}$ & $\begin{array}{l}\text { repairs were performed and complete } \\
\text { 10. Vegetation was re-seeded and replai }\end{array}$ \\
\hline \multicolumn{2}{|c|}{ 6. Have the site maintenance and repair records been reviewed? } & & & & \\
\hline \multicolumn{2}{|c|}{$\begin{array}{l}\text { a. If so, has site repair resulted in a change from as-built } \\
\text { conditions? }\end{array}$} & & $\checkmark$ & NA & \\
\hline \multicolumn{2}{|c|}{$\begin{array}{l}\text { b. If yes (to 6a), are revised as-built plans available that reflect } \\
\text { repair changes? }\end{array}$} & & & $\sqrt{\mathrm{NA}}$ & \\
\hline \multicolumn{6}{|l|}{ C. SITE INSPECTION PREPARATION } \\
\hline \multicolumn{6}{|c|}{$\begin{array}{l}\text { Assemble the following, as needed, to conduct inspections: } \\
\text { a. Camera, digital storage drive, and extra batteries } \\
\text { b. Keys to locks } \\
\text { c. Clipboard } \\
\text { d. Tape measure } \\
\text { e. Radio, pager, etc. } \\
\text { f. Previous Post-Closure Report, Inspection Checklists, r } \\
\text { g. Other miscellaneous support equipment }\end{array}$} \\
\hline
\end{tabular}


POST-CLOSURE INSPECTION CHECKLIST

\section{CAU 110: AREA 3 WMD U-3ax/bl CRATER - CAS 03-23-04: U-3axbl Subsidence Crater}

\section{SITE INSPECTION}

- The site inspection is a walking inspection of the entire site including the perimeter and sufficient transects to be able to inspect the entire surface and all features specifically described in this checklist. The checklist should be completed during the site inspection.

- If a shaded box is checked, add detailed comments to document the results of the site inspection. Information provided should be of sufficient detail to enable reconstruction of observations regarding field conditions. Information can take the form of written narrative, sketches, measurements, and annotated site maps, all of which should be placed on additional attachments (if needed) and cross-reference appropriately. Attach the additional pages and number all pages upon completion of the inspection. The completed checklist is part of the field record of the inspection.

- Field notes taken to assist in completion of this checklist will become part of the inspection record. No form is specified for field notes, and additional field notes are not required if the checklist and associated attachments adequately describe site conditions.

1. Adjacent off-site features:

a. Are there any new activities or features in the vicinity that could potentially affect the site (e.g., activities that change the flow of surface water or are encroaching the unit)?

2. Fences, gates, and signs:

a. Is there damage to or a break in the fence?

b. Is there damage to or a break in the chicken wire fence?

c. Have any fenceposts been damaged or their anchoring weakened?

d. Is the gate intact and functional?

e. Does the gate show evidence of tampering or damage?

f. Was the gate locked?

g. Are any of the use restriction signs damaged or missing?

h. Are all use restriction signs legible?

i. How many use restriction signs need to be replaced?

3. Waste unit cover (Western portion, “ax"):

a. Is there evidence of settling?

b. Is there evidence of cracking?

c. Is there evidence of erosion (wind or water)?

d. Is there evidence of human intrusion onto the cover?

e. Is there evidence of large animal intrusion onto the cover?

f. Is there evidence of animal burrowing?

g. Is there a change or difference in vegetation (i.e., is the vegetation growing on the cover inconsistent with the naturally-occurring vegetation growing outside of the unit)?

h. Other (including trash, debris, etc within fenced area)?

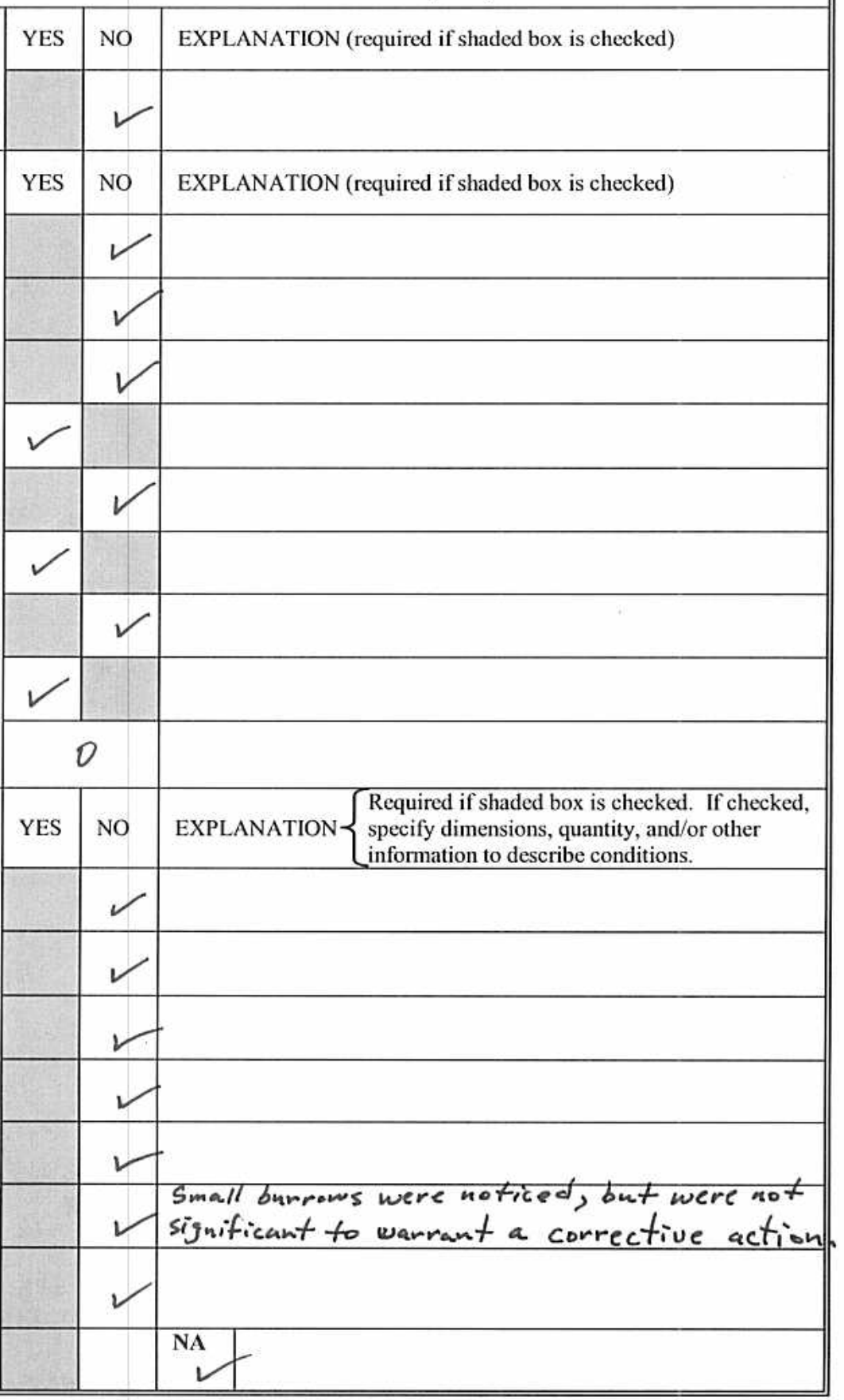




\section{POST-CLOSURE INSPECTION CHECKLIST}

\section{CAU 110: AREA 3 WMD U-3ax/bl CRATER - CAS 03-23-04: U-3axbl Subsidence Crater}

4. Waste unit cover (Eastern portion, "bl"):

a. Is there evidence of settling?

b. Is there evidence of cracking?

c. Is there evidence of erosion (wind or water)?

d. Is there evidence of human intrusion onto the cover?

e. Is there evidence of large animal intrusion onto the cover?

f. Is there evidence of animal burrowing?

g. Is there a change or difference in vegetation (i.e., is the vegetation growing on the cover inconsistent with the naturally-occurring vegetation growing outside of the unit)?

h. Other (including trash, debris, etc within fenced area)?

5. Subsidence survey markers and TDR Probes:

a. Have any of the seven (7) subsidence survey markers been disturbed?

b. Do natural processes threaten the integrity of any subsidence survey marker?

c. Is there excessive vegetation around the subsidence survey markers?

d. Is there any evidence that TDR probes have been disturbed or the wires damaged?

e. Other?

\begin{tabular}{|c|c|c|}
\hline YES & NO & EXPLANATION $\left\{\begin{array}{l}\text { Required if shaded box is checked. If checked, } \\
\text { specify dimensions, quantity, and/or other } \\
\text { information to describe conditions. }\end{array}\right.$ \\
\hline & $v$ & \\
\hline & & \\
\hline & & \\
\hline & & \\
\hline & & \\
\hline & & \\
\hline & & \\
\hline & & $\begin{array}{ll}\mathrm{NA} \\
\mathrm{N}\end{array}$ \\
\hline YES & NO & EXPLANATION (required if shaded box is checked) \\
\hline & & \\
\hline & & \\
\hline & & \\
\hline & & \\
\hline & & NA \\
\hline
\end{tabular}

6. Photograph Instructions:

- A standard set of eight (8) color photographs is required to be taken during each inspection of CAU 110 :

- Four (4) from the center of the unit, one in each compass direction (i.e., N, S, E, W)

- Four (4) of the unit from outside the fence, one in each compass direction (i.e., N, S, E, W).

- In addition, all anomalous features or new features (such as changes in adjacent area land use) are to be photographed.

- Additional photographs may also be taken.

- A photograph log entry will be made for each photograph taken.

7. Photograph Documentation:

a. Have all photographs been taken as required by the photograph instructions?

b. Has a photograph log been prepared?

c. How many photographs were taken?

d. Other?

\section{E. FIELD CONCLUSIONS}

1. Are more frequent inspections required?

2. Are existing maintenance/repair actions satisfactory?

\begin{tabular}{|l|l|l||}
\hline YES & NO & EXPLANATION (required if shaded box is checked) \\
\hline & & \\
\hline & & \\
\hline & & \\
\hline
\end{tabular}




\section{POST-CLOSURE INSPECTION CHECKLIST}

\section{CAU 110: AREA 3 WMD U-3ax/bl CRATER - CAS 03-23-04: U-3axbl Subsidence Crater}

\section{E. FIELD CONCLUSIONS (continued)}

3. Are general housekeeping (i.e., "minor") maintenance/repair actions needed (includes cracks or settling imperfections less than 6 inches deep that extend less than 3 feet on the cover)? [minor repairs]

4. Are there any deficiencies that require a remedy other than general housekeeping or small (less than 6 inches deep and 3 feet long) cracks or settling imperfections of the cover? [i.e., more than "minor repairs"]

5. Will necessary repairs change the as-built condition of the unit?

\begin{tabular}{|l|l|l|} 
YES & NO & EXPLANATION (required if shaded box is checked) \\
& If "yes", describe in Field conclusions/recommendations \\
\hline & $\begin{array}{l}\text { If "yes", describe below and the Task Manager must complete the } \\
\text { "Follow-up Actions" (not part of checklist) }\end{array}$ \\
\hline
\end{tabular}

6. Field conclusions/recommendations: The UR signage, fencing, and surface grade monuments are in excellent condition. There was no evidence of more subsidence or settling since the subsidence repairs were completed in Jan. 2010. A few small animal burrows were noticed, but nothing was deemed significant enongh to warrant a follow-up corrective action. Also, new vegetation was re-seeded and replanted on the east portion of the cover. The new vegetation was protected with temporary fencing to prevent intrusion by small animals. There are no issnes or concerus at this site.

\section{F. CERTIFICATION}

I have conducted an inspection of CAU 110, Area 3 WMD U-3ax/bl Crater, in accordance with the procedures of the Post-Closure Permit (including the Post-Closure Plan) as recorded on this checklist, attached sheets, field notes, photographs, and photograph logs.

Chief Inspector's Signature/s/: Glenn Richardson Date: $3 / 17 / 10$ Printed Name: Glenn Richardson

\section{Required Attachments:}

1. Field Notes

2. Photos (or note File Location: S:INTS\ER Share Photos (CAu 110 2010 $03-17-2010$ Inspection )

Distribution: Original - Industrial Sites Project Manager Copy - Task Manager

\section{G. VERIFICATION}

I have reviewed this checklist and attachments and have verified that it is complete.

\section{Signaturc: /s/: Reed Poderis}




\section{POST-CLOSURE INSPECTION CHECKLIST}

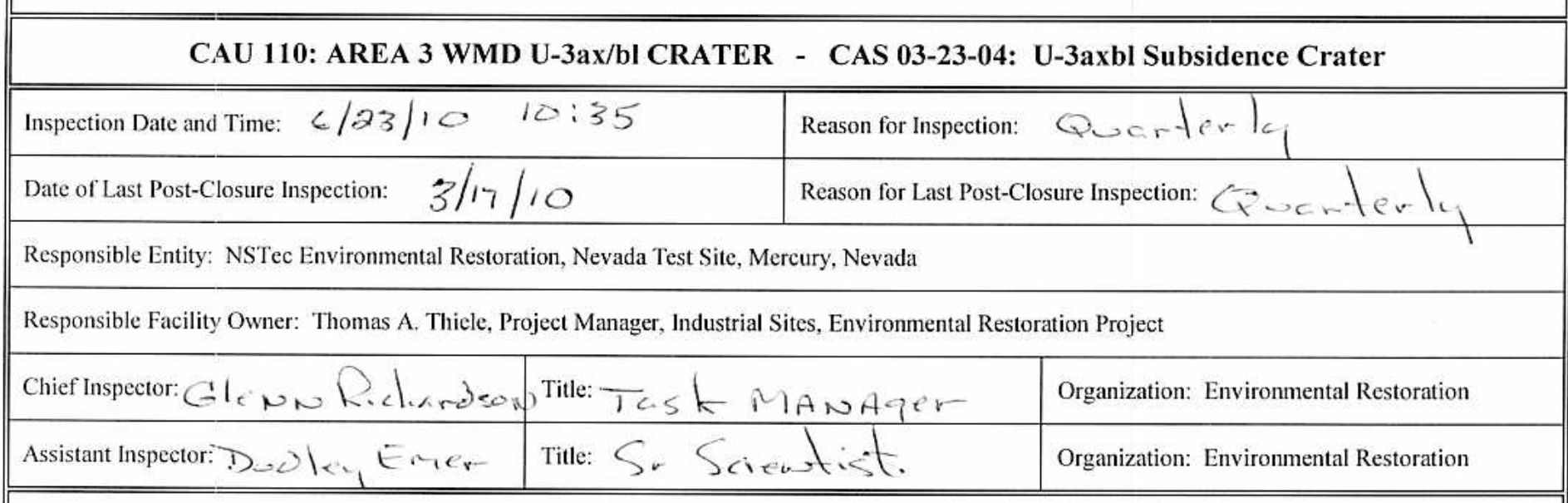

\section{A. GENERAL INSTRUCTIONS}

- Complete all checklist items.

- If a SHADED BOX is checked, provide detailed information regarding what was found and/or appropriate references to other documents that have the information (e.g., Maintenance Order Form for CAU 91 dated 2/15/2008).

- All documentation must be legible and clear.

\begin{tabular}{|c|c|c|c|c|}
\hline B. PREPARATION (To be competed prior to site visit) & YES & NO & \multicolumn{2}{|r|}{ EXPLANATION (required if shaded box is checked) } \\
\hline \multicolumn{5}{|l|}{ 1. Has the Post-Closure Permit been reviewed? } \\
\hline \multicolumn{5}{|l|}{ 2. Has the Post-Closure Permit application been reviewed? } \\
\hline \multicolumn{5}{|l|}{ 3. Has the Post-Closure Plan been reviewed? } \\
\hline \multicolumn{5}{|l|}{ 4. Have the site as-built plans and site base map been reviewed? } \\
\hline \multicolumn{5}{|l|}{ 5. Have the previous inspection reports been reviewed? } \\
\hline \multicolumn{5}{|l|}{ a. Were anomalies or trends detected on previous inspections? } \\
\hline b. Was maintenance performed? & & & & \\
\hline \multicolumn{5}{|l|}{ 6. Have the site maintenance and repair records been reviewed? } \\
\hline $\begin{array}{l}\text { a. If so, has site repair resulted in a change from as-built } \\
\text { conditions? }\end{array}$ & & & NA & \\
\hline $\begin{array}{l}\text { b. If yes (to } 6 \text { a), are revised as-built plans available that reflect } \\
\text { repair changes? }\end{array}$ & & & NA & \\
\hline
\end{tabular}

\section{SITE INSPECTION PREPARATION}

Assemble the following, as needed, to conduct inspections:
a. Camera, digital storage drive, and extra batteries
b. Keys to locks
c. Clipboard
d. Tape measure
e. Radio, pager, etc.
f. Previous Post-Closure Report, Inspection Checklists, repair records, and as-built plans
g. Other miscellaneous support equipment 


\section{POST-CLOSURE INSPECTION CHECKLIST}

\section{CAU 110: AREA 3 WMD U-3ax/bI CRATER - CAS 03-23-04: U-3axbl Subsidence Crater}

\section{SITE INSPECTION}

- The site inspection is a walking inspection of the entire site including the perimeter and sufficient transects to be able to inspect the entire surface and all features specifically described in this checklist. The checklist should be completed during the site inspection.

- If a shaded box is checked, add detailed comments to document the results of the site inspection. Information provided should be of sufficient detail to enable reconstruction of observations regarding field conditions. Information can take the form of written narrative, sketches, measurements, and annotated site maps, all of which should be placed on additional attachments (if needed) and cross-reference appropriately. Attach the additional pages and number all pages upon completion of the inspection. The completed checklist is part of the field record of the inspection.

- Field notes taken to assist in completion of this checklist will become part of the inspection record. No form is specified for field notes, and additional field notes are not required if the checklist and associated attachments adequately describe site conditions.

1. Adjacent off-site features:

a. Are there any new activities or features in the vicinity that could potentially affect the site (e.g., activities that change the flow of surface water or are encroaching the unit)?

2. Fences, gates, and signs:

a. Is there damage to or a break in the fence?

b. Is there damage to or a break in the chicken wire fence?

c. Have any fenceposts been damaged or their anchoring weakened?

d. Is the gate intact and functional?

e. Does the gate show evidence of tampering or damage?

f. Was the gate locked?

g. Are any of the use restriction signs damaged or missing?

h. Are all use restriction signs legible?

i. How many use restriction signs need to be replaced?

3. Waste unit cover (Western portion, "ax"):

a. Is there evidence of settling?

b. Is there evidence of cracking?

c. Is there evidence of erosion (wind or water)?

d. Is there evidence of human intrusion onto the cover?

e. Is there evidence of large animal intrusion onto the cover?

f. Is there evidence of animal burrowing?

g. Is there a change or difference in vegetation (i.e., is the vegetation growing on the cover inconsistent with the naturally-occurring vegetation growing outside of the unit)?

h. Other (including trash, debris, etc within fenced area)?

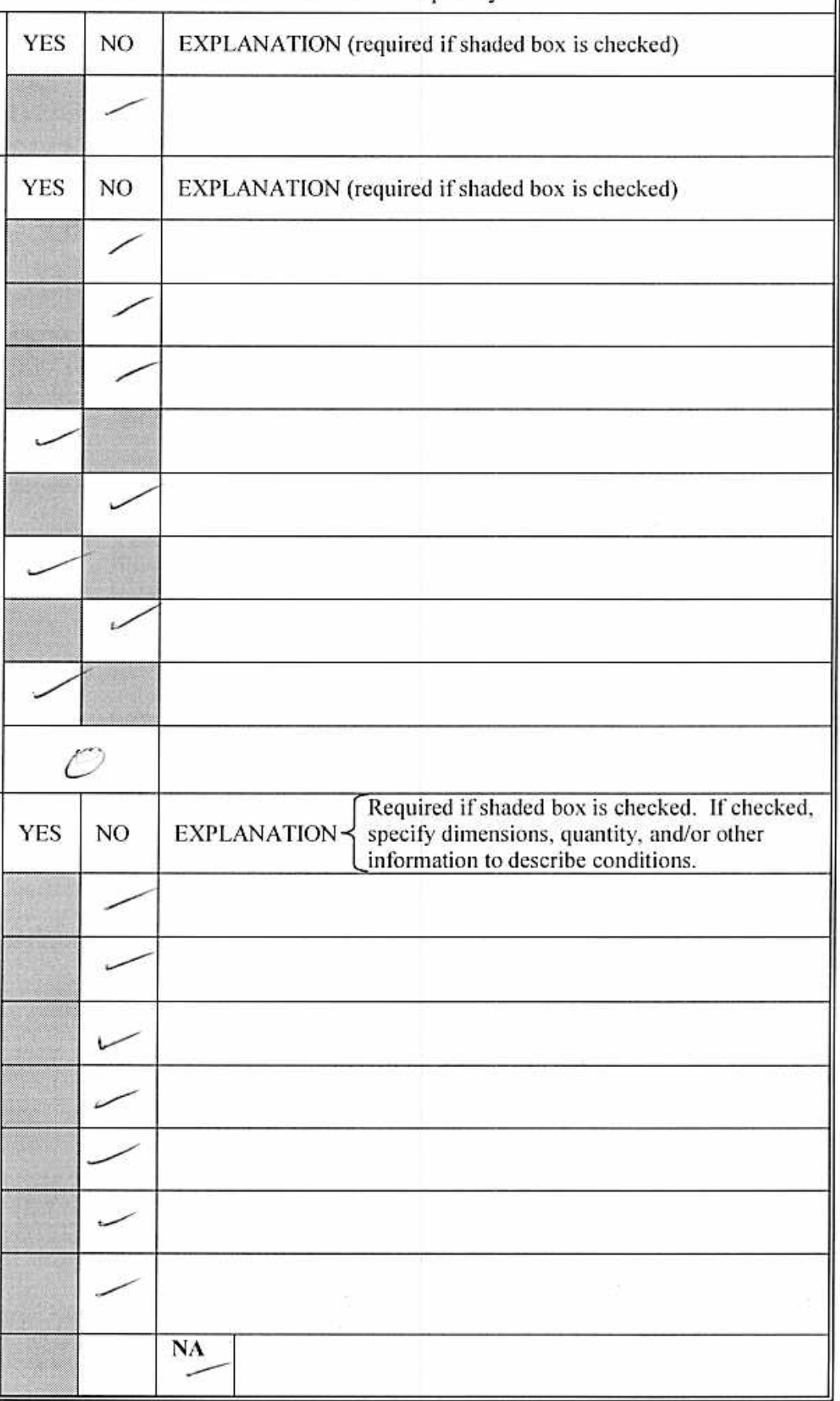




\section{POST-CLOSURE INSPECTION CHECKLIST}

\section{CAU 110: AREA 3 WMD U-3ax/bl CRATER - CAS 03-23-04: U-3axbl Subsidence Crater}

4. Waste unit cover (Eastern portion, "bl"):

a. Is there evidence of settling?

b. Is there evidence of cracking?

c. Is there evidence of crosion (wind or water)?

d. Is there evidence of human intrusion onto the cover?

e. Is there evidence of large animal intrusion onto the cover?

f. Is there evidence of animal burrowing?

g. Is there a change or difference in vegetation (i.e., is the vegetation growing on the cover inconsistent with the naturally-occurring vegetation growing outside of the unit)?

h. Other (including trash, debris, etc within fenced area)?

5. Subsidence survey markers and TDR Probes:

a. Have any of the seven (7) subsidence survey markers been disturbed?

b. Do natural processes threaten the integrity of any subsidence survey marker?

c. Is there excessive vegetation around the subsidence survey markers?

d. Is there any evidence that TDR probes have been disturbed or the wires damaged?

e. Other?

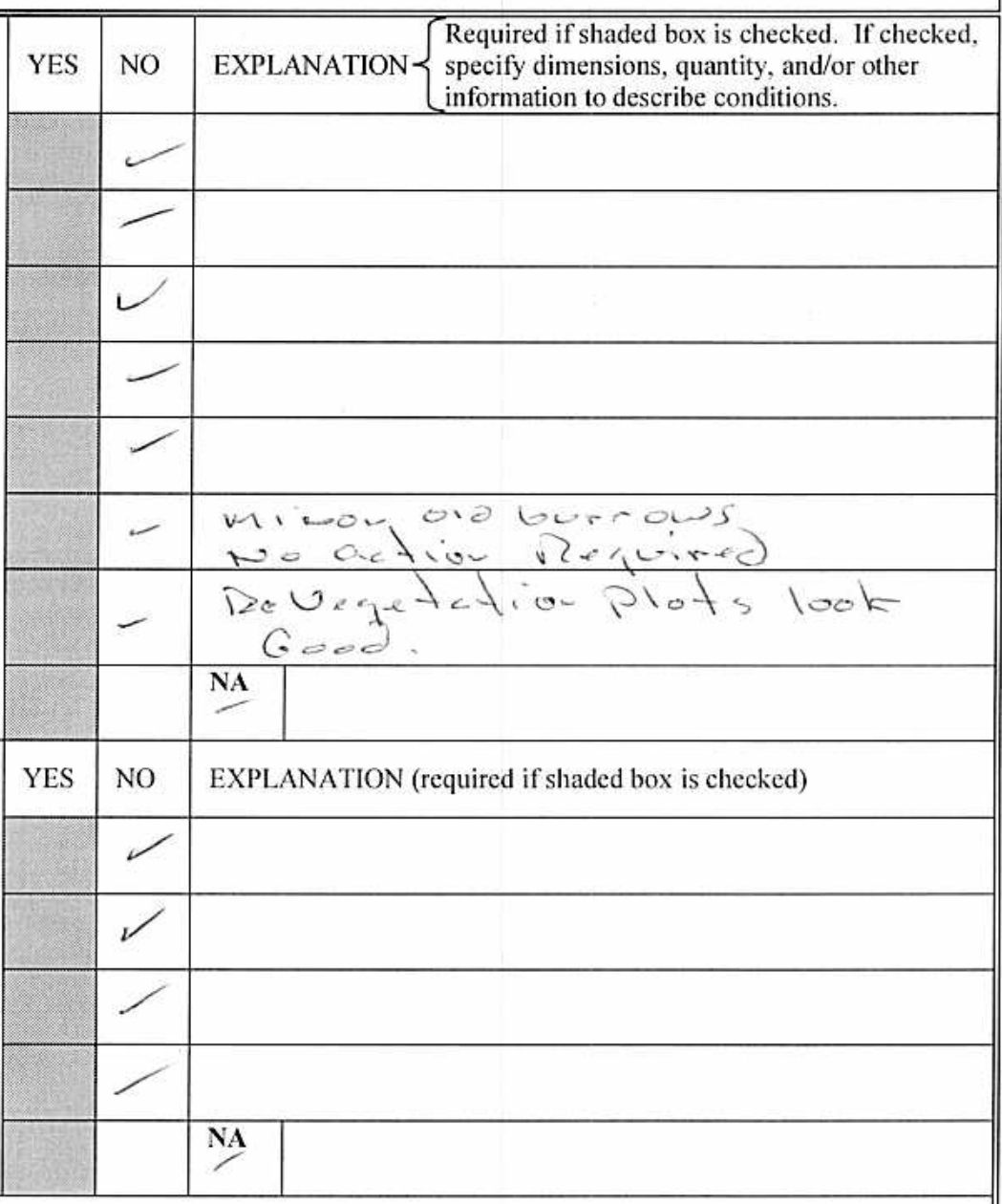

6. Photograph Instructions:

- A standard set of eight (8) color photographs is required to be taken during each inspection of CAU 110 :

- Four (4) from the center of the unit, one in each compass direction (i.e., N, S, E, W)

- Four (4) of the unit from outside the fence, one in each compass direction (i.e., N, S, E, W).

- In addition, all anomalous features or new features (such as changes in adjacent area land use) are to be photographed.

- Additional photographs may also be taken.

- A photograph log entry will be made for each photograph taken.

7. Photograph Documentation:

a. Have all photographs been taken as required by the photograph instructions?

b. Has a photograph log been prepared?

c. How many photographs were taken?

d. Other?

\section{E. FIELD CONCLUSIONS}

1. Are more frequent inspections required?

2. Are existing maintenance/repair actions satisfactory?

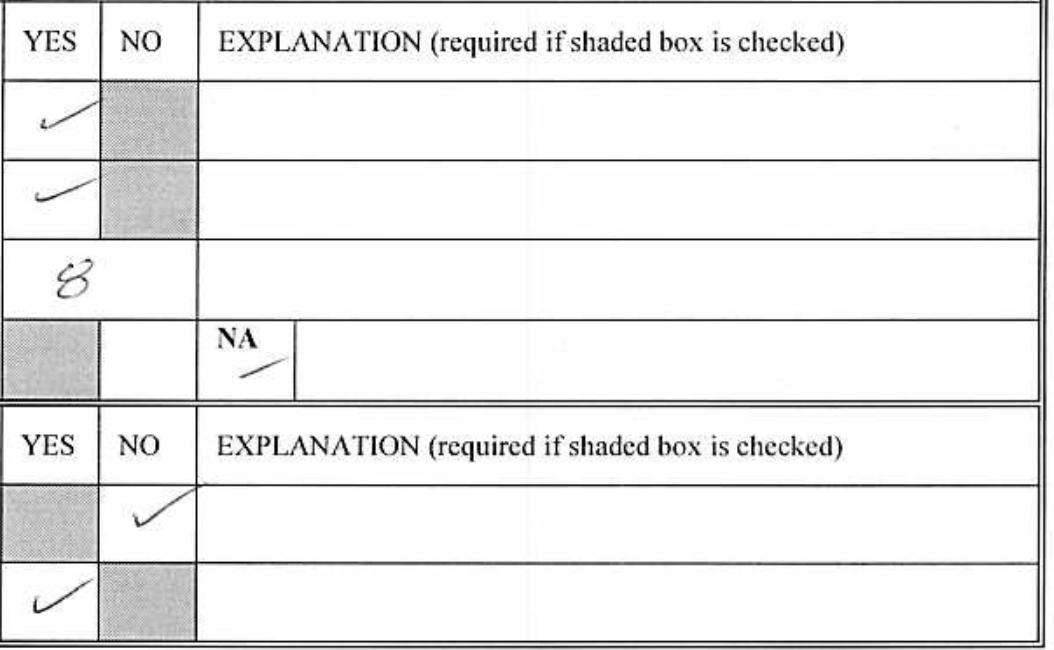




\section{POST-CLOSURE INSPECTION CHECKLIST}

\section{CAU 110: AREA 3 WMD U-3ax/bl CRATER - CAS 03-23-04: U-3axbl Subsidence Crater}

\section{E. FIELD CONCLUSIONS (continued)}

3. Are general housekeeping (i.e., "minor") maintenance/repair actions needed (includes cracks or settling imperfections less than 6 inches deep that extend less than 3 feet on the cover)? [minor repairs]

4. Are there any deficiencies that require a remedy other than general housekeeping or small (less than 6 inches deep and 3 feet long) cracks or settling imperfections of the cover? [i.e., more than "minor repairs"]

5. Will necessary repairs change the as-built condition of the unit?

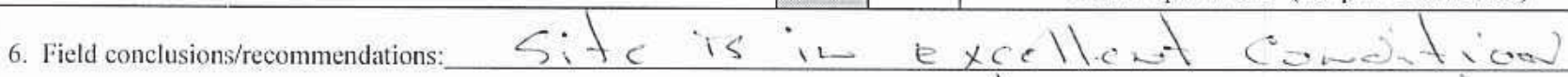
wo bew, dractures or Sulsiberece W.

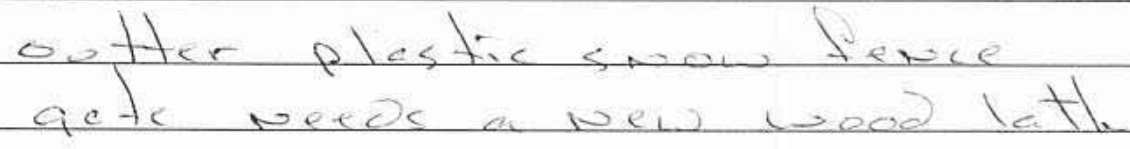

\section{F. CERTIFICATION}

I have conducted an inspection of CAU 110, Area 3 WMD U-3ax/bl Crater, in accordance with the procedures of the Post-Closure Permit (including the Post-Closure Plan) as recorded on this checklist, attached sheets, field notes, photographs, and photograph logs.

Chief Inspector's signature/s/: Glenn Richardson Date: $6 / 23 / 10$ Printed Name: Gienn Richardson

Required Attachments:

1. Field Notes

2. Photos (or note File Location: S:INTSIER Sharel Photosl CAM $110(2010106-23-2010$ Inspection )

Distribution: Original - Industrial Sites Project Manager

Copy - Task Manager

\section{G. VERIFICATION}

I have reviewed whis checklist and attachments and have verified that it is complete.

Signature: /s/: Reed Poderis

Printed Name: Thomas A. Thiele (or designee)

Distribution: Original - Task Manager 


\section{POST-CLOSURE INSPECTION CHECKLIST}

\begin{tabular}{|c|c|c|c|}
\hline \multicolumn{2}{|c|}{ CAU 110: AREA 3 WMD U-3ax/bl CRATER } & \multicolumn{2}{|c|}{ - CAS 03-23-04: U-3axbl Subsidence Crater } \\
\hline Inspection Date and Time: & $10: 50 \mathrm{AM}$ & Reason fo & Quarterly \\
\hline Date of Last Post-Closure Inspection: & & Reason fo & sure Inspection: Quarter/y \\
\hline \multicolumn{4}{|c|}{ Responsible Entity: NSTec Environmental Restoration, Nevada Test Site, Mercury, Nevada } \\
\hline \multicolumn{4}{|c|}{ Responsible Facility Owner: Thomas A. Thiele, Project Manager, Industrial Sites, Environmental Restoration Project } \\
\hline Chief Inspector: Glenn Richardson & Title: Task Ma & nager & Organization: Environmental Restoration \\
\hline Assistant Inspector: & 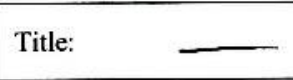 & & Organization: Environmental Restoration \\
\hline
\end{tabular}

\section{A. GENERAL INSTRUCTIONS}

- Complete all checklist items.

- If a SHADED BOX is checked, provide detailed information regarding what was found and/or appropriate references to other documents that have the information (e.g., Maintenance Order Form for CAU 91 dated 2/15/2008).

- All documentation must be legible and clear.

\begin{tabular}{||l|l|l|l|}
\hline \hline B. PREPARATION (To be competed prior to site visit) & 1. Has the Post-Closure Permit been reviewed? & EXPLANATION (required if shaded box is checked) \\
\hline $\begin{array}{l}\text { 2. Has the Post-Closure Permit application been reviewed? } \\
\text { 3. Has the Post-Closure Plan been reviewed? }\end{array}$ & $\begin{array}{l}\text { a. Were anomalies or trends detected on previous inspections? } \\
\text { 4. Have the site as-built plans and site base map been reviewed? }\end{array}$ & &
\end{tabular}

\section{SITE INSPECTION PREPARATION}

Assemble the following, as needed, to conduct inspections:
a. Camera, digital storage drive, and extra batteries
b. Keys to locks
c. Clipboard
d. Tape measure
e. Radio, pager, etc.
f. Previous Post-Closure Report, Inspection Checklists, repair records, and as-built plans
g. Other miscellaneous support equipment 


\section{POST-CLOSURE INSPECTION CHECKLIST}

\section{CAU 110: AREA 3 WMD U-3ax/bl CRATER - CAS 03-23-04: U-3axbl Subsidence Crater}

\section{SITE INSPECTION}

- The site inspection is a walking inspection of the entire site including the perimeter and sufficient transects to be able to inspect the entire surface and all features specifically described in this checklist. The checklist should be completed during the site inspection.

- If a shaded box is checked, add detailed comments to document the results of the site inspection. Information provided should be of sufficient detail to enable reconstruction of observations regarding field conditions. Information can take the form of written narrative, sketches, measurements, and annotated site maps, all of which should be placed on additional attachments (if needed) and cross-reference appropriately. Attach the additional pages and number all pages upon completion of the inspection. The completed checklist is part of the field record of the inspection.

- Field notes taken to assist in completion of this checklist will become part of the inspection record. No form is specified for field notes, and additional field notes are not required if the checklist and associated attachments adequately describe site conditions.

1. Adjacent off-site features:

a. Are there any new activities or features in the vicinity that could potentially affect the site (e.g., activities that change the flow of surface water or are encroaching the unit)?

2. Fences, gates, and signs:

a. Is there damage to or a break in the fence?

b. Is there damage to or a break in the chicken wire fence?

c. Have any fenceposts been damaged or their anchoring weakened?

d. Is the gate intact and functional?

e. Does the gate show evidence of tampering or damage?

f. Was the gate locked?

g. Are any of the use restriction signs damaged or missing?

h. Are all use restriction signs legible?

i. How many use restriction signs need to be replaced?

3. Waste unit cover (Western portion, "ax"):

a. Is there evidence of settling?

b. Is there evidence of cracking?

c. Is there evidence of erosion (wind or water)?

d. Is there evidence of human intrusion onto the cover?

e. Is there evidence of large animal intrusion onto the cover?

f. Is there evidence of animal burrowing?

g. Is there a change or difference in vegetation (i.e., is the vegetation growing on the cover inconsistent with the naturally-occurring vegetation growing outside of the unit)?

h. Other (including trash, debris, etc within fenced area)?

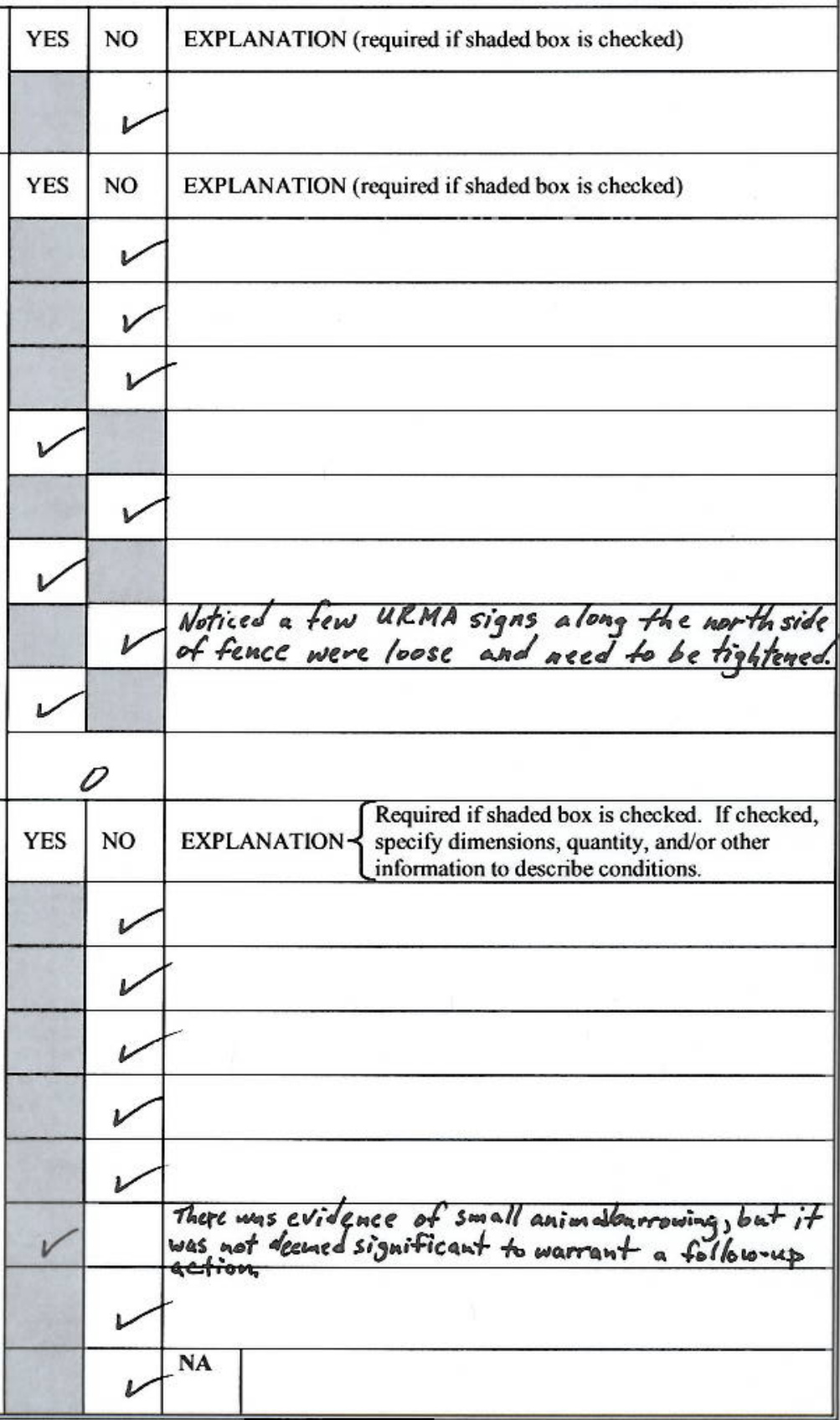




\section{POST-CLOSURE INSPECTION CHECKLIST}

\section{CAU 110: AREA 3 WMD U-3ax/bI CRATER - CAS 03-23-04: U-3axbl Subsidence Crater}

4. Waste unit cover (Eastern portion, "bl"):

a. Is there evidence of settling?

b. Is there evidence of cracking?

c. Is there evidence of erosion (wind or water)?

d. Is there evidence of human intrusion onto the cover?

e. Is there evidence of large animal intrusion onto the cover?

f. Is there evidence of animal burrowing?

g. Is there a change or difference in vegetation (i.e., is the vegetation growing on the cover inconsistent with the naturally-occurring vegetation growing outside of the unit)?

h. Other (including trash, debris, etc within fenced area)?

5. Subsidence survey markers and TDR Probes:

a. Have any of the seven (7) subsidence survey markers been disturbed?

b. Do natural processes threaten the integrity of any subsidence survey marker?

c. Is there excessive vegetation around the subsidence survey markers?

d. Is there any evidence that TDR probes have been disturbed or the wires damaged?

e. Other?

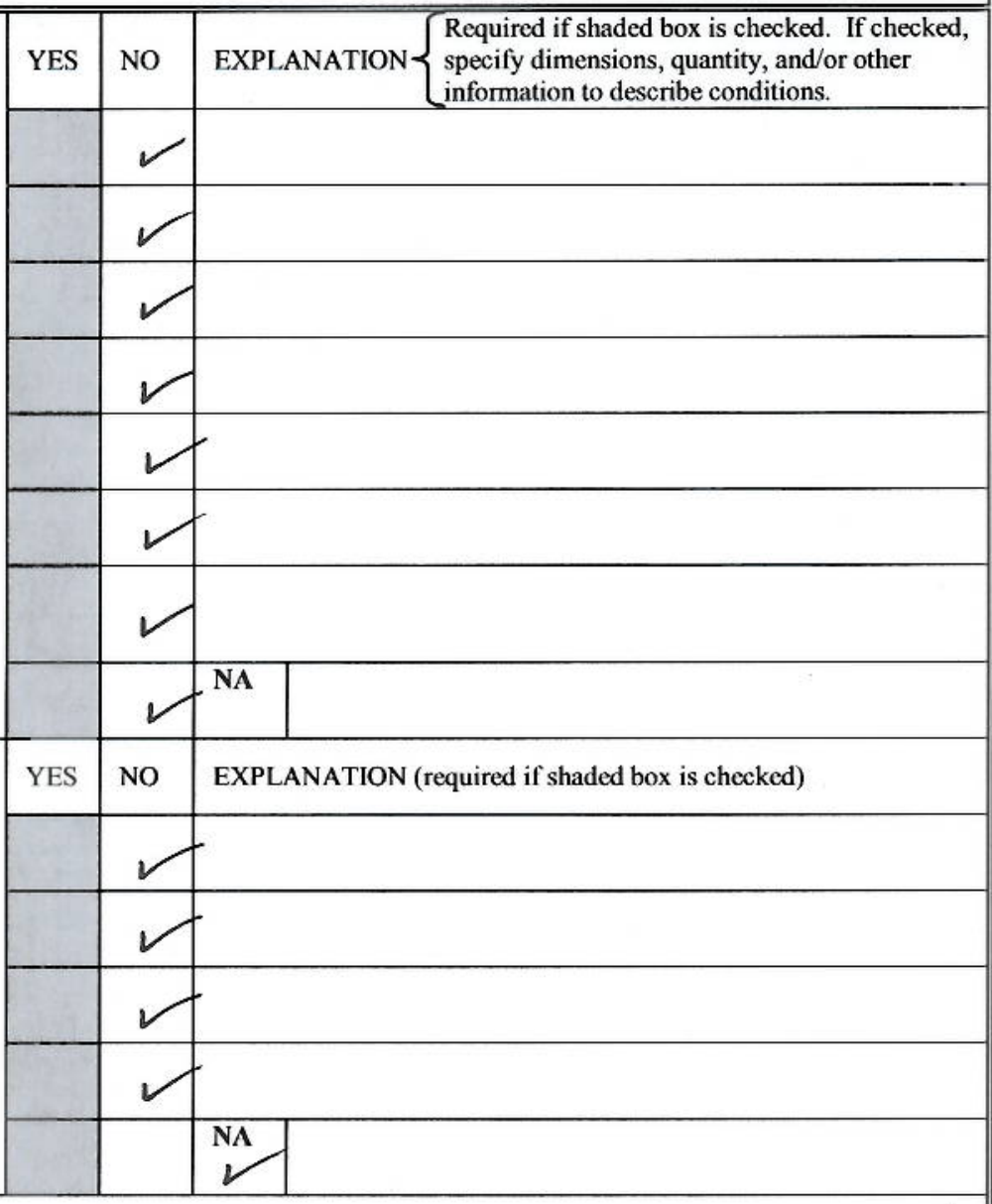

6. Photograph Instructions:

- A standard set of eight (8) color photographs is required to be taken during each inspection of CAU 110 :

- Four (4) from the center of the unit, one in each compass direction (i.e., N, S, E, W)

- Four (4) of the unit from outside the fence, one in each compass direction (i.e., N, S, E, W).

- In addition, all anomalous features or new features (such as changes in adjacent area land use) are to be photographed.

- Additional photographs may also be taken.

- A photograph log entry will be made for each photograph taken.

7. Photograph Documentation:

a. Have all photographs been taken as required by the photograph instructions?

b. Has a photograph log been prepared?

c. How many photographs were taken?

d. Other?

\section{E. FIELD CONCLUSIONS}

1. Are more frequent inspections required?

2. Are existing maintenance/repair actions satisfactory?

\begin{tabular}{|l|l|l|l||}
\hline YES & NO & EXPLANATION (required if shaded box is checked) \\
\hline
\end{tabular}




\section{POST-CLOSURE INSPECTION CHECKLIST}

\section{CAU 110: AREA 3 WMD U-3ax/bl CRATER - CAS 03-23-04: U-3axbl Subsidence Crater}

\section{E. FIELD CONCLUSIONS (continued)}

3. Are general housekeeping (i.e., "minor") maintenance/repair actions needed (includes cracks or settling imperfections less than 6 inches deep that extend less than 3 feet on the cover)? [minor repairs]

4. Are there any deficiencies that require a remedy other than general housekeeping or small (less than 6 inches deep and 3 feet long) cracks or settling imperfections of the cover? [i.e., more than "minor repairs"]

5. Will necessary repairs change the as-built condition of the unit?

\begin{tabular}{|l|l|l}
\hline YES & NO & EXPLANATION (required if shaded box is checked) \\
\hline & & $\begin{array}{l}\text { If "yes", describe in Field conclusions/recommendations } \\
\text { If "yes", describe below and the Task Manager must complete the } \\
\text { "Follow-up Actions" (not part of checklist) }\end{array}$ \\
\hline & $\begin{array}{l}\text { If "yes", describe below and the Task Manager must complete the } \\
\text { "Follow-up Actions" (not part of checklist) }\end{array}$ \\
\hline
\end{tabular}

6. Field conclusions/recommendations: The use restriction signs, fencing, and the vegetative cover were in good condition; however, there were a few URMA signs along the morth side of the fence that were loose and needed to be fightened. The surface-grade wonuments were in good condition and the new vegetation that was reestablished on the east portion of the cover appeared to be matuming very well. There was no evidence of cracks, subsidence, or setflingonthe cover. There were some small animal burrows noticed, bat nothing warranted a follow-up action. There were no issues or concerns at this site, but the URMA signs will be reinforced along the north side of the fence.

\section{F. CERTIFICATION}

I have conducted an inspection of CAU 110, Area 3 WMD U-3ax/bl Crater, in accordance with the procedures of the Post-Closure Permit (including the Post-Closure Plan) as recorded on this checklist, attached sheets, field notes, photographs, and photograph logs.

chief Inspector's signatufs/: Glênn Richârdson Date: $9 / 8 / 10$

Printed Name: Gleas Richardson Title: Task Manager

Required Attachments:

1. Field Notes
2. Photos (or note File Location: S: WTS LER Share 1 Photos $\mid$ CAu $110|2010| 09-08-2010$ Inspection)

Distribution: Original - Industrial Sites Project Manager

Copy - Task Manager

\section{G. VERIFICATION}

I have reviewe of this checklist and attachments and have verified that it is complete.

Signatur: /S/: Reed Poderis

Printed Name: IThomas A. Thiele (or designee)

Distribution: Original - Task Manager 
RCRA Post-Closure Report

Revision: 0

Date: January 2011

\section{CORRECTIVE ACTION UNIT 112 INSPECTION CHECKLISTS}


RCRA Post-Closure Report

Revision: 0

Date: January 2011

\section{THIS PAGE INTENTIONALLY LEFT BLANK}




\section{POST-CLOSURE INSPECTION CHECKLIST}

CAU 112: AREA 23 H \ZARDOUS WASTE TRENCHES - CAS 23-21-02: Area 23 Haz. Waste Trenches (RCRA)

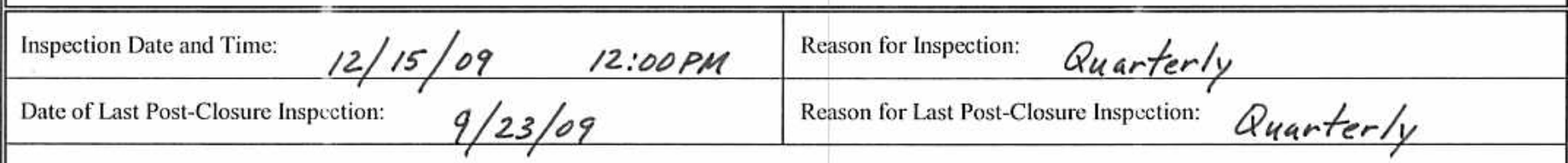

Responsible Entity: NSTec Environmental Restoration, Nevada Test Site, Mercury, Nevada

Responsible Facility Owner: Thomas A. Thiele, Project Manager, Industrial Sites, Environmental Restoration Project

\begin{tabular}{|l|l|l|}
\hline Chief Inspector: Glenn Richardson & Title: Task Manager & Organization: Environmental Restoration \\
\hline Assistant Inspector: Greg Doyle & Title: Sr. Scientist & Organization: Environmental Restoration \\
\hline \hline
\end{tabular}

A. GENERAL INSTRUCTIONS

- Complete all checklist items.

- If a SHADED BOX is checked, provide detailed information regarding what was found and/or appropriate references to other documents that have the information (e.g., Maintenance Order Form for CAU 92 dated 2/15/2008).

- All documentation must be legible and clear.

\begin{tabular}{|c|c|c|c|}
\hline B. PREPARATION (To be competed prior to site visit) & YES & NO & EXPLANATION (required if shaded box is checked) \\
\hline \multicolumn{4}{|l|}{ 1. Has the Post-Closure Permit been reviewed? } \\
\hline \multicolumn{4}{|l|}{ 2. Has the Post-Closure Permit application been reviewed? } \\
\hline \multicolumn{4}{|l|}{ 3. Has the Post-Closure Plan been reviewed? } \\
\hline \multicolumn{4}{|l|}{ 4. Have the site as-built plans and site base map been reviewed? } \\
\hline \multicolumn{4}{|l|}{ 5. Have the previous inspection reports been reviewed? } \\
\hline \multicolumn{4}{|l|}{ a. Were anomalies or trends detected on previous inspections? } \\
\hline \multicolumn{4}{|l|}{ b. Was maintenance performed? } \\
\hline \multicolumn{4}{|l|}{ 6. Have the site maintenance and repair records been reviewed? } \\
\hline $\begin{array}{l}\text { a. If so, has site repair resulted in a change from as-built } \\
\text { conditions? }\end{array}$ & & & NA \\
\hline $\begin{array}{l}\text { b. If yes (to } 6 a \text { ), are revised as-built plans available that reflect } \\
\text { repair changes? }\end{array}$ & & & NA \\
\hline
\end{tabular}

\section{SITE INSPECTION PREPARATION}

Assemble the following, as needed, to conduct inspections:

a. Camera, digital storage drive, and extra batteries

b. Keys to locks

c. Clipboard

d. Tape measure

e. Radio, pager, etc.

f. Previous Post-Closure Report, Inspection Checklists, repair records, and as-built plans

g. Other miscellaneous support equipment 


\section{POST-CLOSURE INSPECTION CHECKLIST}

\section{CAU 112: AREA 23 HAZARDOUS WASTE TRENCHES - CAS 23-21-02: Area 23 Haz. Waste Trenches (RCRA)}

\section{SITE INSPECTION}

- The site inspection is a walking inspection of the entire site including the perimeter and sufficient transects to be able to inspect the entire surface and all features specifically described in this checklist. The checklist should be completed during the site inspection.

- If a shaded box is checked, add detailed comments to document the results of the site inspection. Information provided should be of sufficient detail to enable reconstruction of observations regarding field conditions. Information can take the form of written narrative, sketches, measurements, and annotated site maps, all of which should be placed on additional attachments (if needed) and cross-reference appropriately. Attach the additional pages and number all pages upon completion of the inspection. The completed checklist is part of the field record of the inspection.

- Field notes taken to assist in completion of this checklist will become part of the inspection record. No form is specified for field notes, and additional field notes are not required if the checklist and associated attachments adequately describe site conditions.

1. Adjacent off-site features:

a. Are there any new activities or features in the vicinity that could potentially affect the site (e.g., activities that change the flow of surface water or are encroaching the unit)?

2. Fences, gates, and signs (East Fenced Enclosure):

a. Is there damage to or a break in the fence?

b. Have any fenceposts been damaged or their anchoring weakened?

c. Is the gate intact and functional?

d. Does the gate show evidence of tampering or damage?

e. Was the gate locked?

f. Are any of the use restriction signs damaged or missing?

g. Are all use restriction signs legible?

h. How many use restriction signs need to be replaced?

i. Other?

3. Monuments:

a. Have landfill monuments been disturbed?

b. Do natural processes threaten the integrity of any landfill monuments?

c. Is there excessive vegetation around the landfill monuments?

d. Other?

4. Neutron Access Pads:

a. Have neutron access pads been disturbed?

b. Are well covers for neutron access tubes broken, lost, or otherwise damaged?

c. Other?

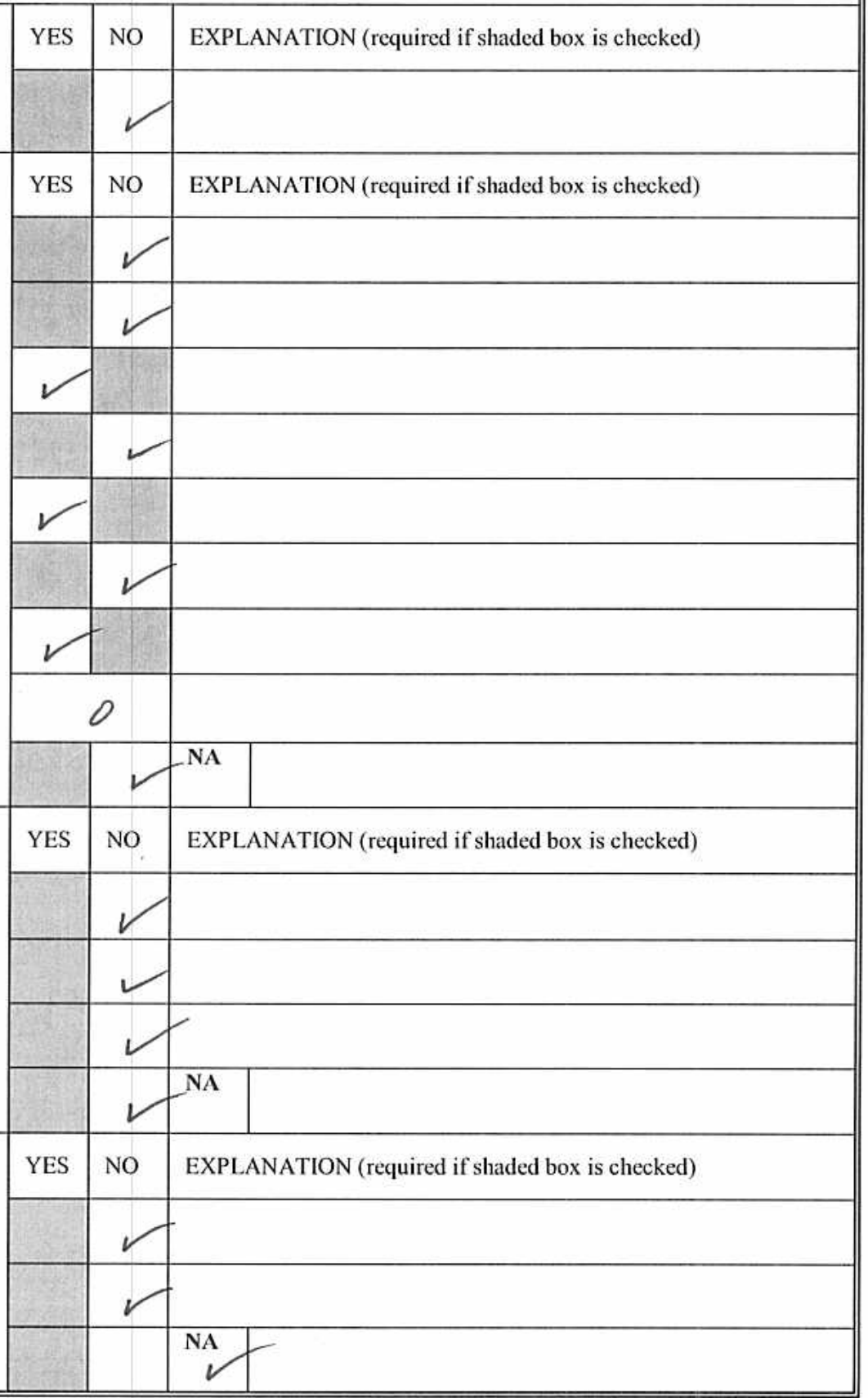




\section{POST-CLOSURE INSPECTION CHECKLIST}

CAU 112: AREA 23 HAZARDOUS WASTE TRENCHES - CAS 23-21-02: Area 23 Haz. Waste Trenches (RCRA)

5. Waste unit cover:

a. Is there evidence of settling?

b. Is there evidence of cracking?

c. Is there evidence of erosion (wind or water)?

d. Is there evidence of human intrusion onto the cover?

e. Is there evidence of large animal intrusion onto the cover?

f. Is there evidence of animal burrowing?

g. Is vegetation growing on the cover?

h. Is there any obvious damage to the cover or plastic liner?

i. Other (including trash, debris, etc within fenced area)?

\begin{tabular}{|c|c|c|}
\hline YES & NO & EXPLANATION (required if shaded box is checked) \\
\hline & 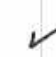 & \\
\hline & & \\
\hline & & \\
\hline & & \\
\hline & & \\
\hline & & \\
\hline$\checkmark$ & & $\begin{array}{l}\text { Discovered new vegetation on top and along the } \\
\text { sides of the rip rap rock cover. }\end{array}$ \\
\hline & $V$ & NA \\
\hline
\end{tabular}

6. Photograph Instructions:

- Photographs should be taken to document maintenance/repair needs at the site. These will be used to plan maintenance/repair activities and are not intended for use in the post-closure annual report.

- Anomalous features or new features (such as changes in adjacent area land use) should be photographed.

- Other photographs are optional.

- A photograph log entry will be made for each photograph taken.

7. Photograph Documentation:

a. Have photographs been taken of the site?

If yes, how many photos were taken?

If yes, has a photographic log been prepared?

\section{E. FIELD CONCLUSIONS}

1. Are more frequent inspections required?

2. Are existing maintenance/repair actions satisfactory?

3. Is other maintenance/repair necessary?

4. Is there obvious damage to the cover or plastic liner?

5. Will necessary repairs change the as-built condition of the unit?

\begin{tabular}{|l|l|l|}
\hline YES & NO & EXPLANATION \\
\hline & & $\begin{array}{l}\text { Photo documentation of the new vegetation on } \\
\text { top and along the sides of the rip rap cover }\end{array}$ \\
\hline 4 & & \\
\hline YES & NO & EXPLANATION (required if shaded box is checked) \\
\hline & & \begin{tabular}{l} 
If yes, describe below \\
\hline
\end{tabular} \\
\hline & $\begin{array}{l}\text { If "yes", describe below and the Task Manager must complete the } \\
\text { "Follow-up Actions" (not part of checklist) }\end{array}$ \\
\hline &
\end{tabular}

6. Field conclusions/recommendations: The fencing, $u R$ signs, and aboveground monuments are in great condition. There is evidence of new vegetation on top of the cover and aloug the side slopes. Vegetation removal and/or applying un herbicide is necessary as a follow-up corrective action. 


\section{POST-CLOSURE INSPECTION CHECKLIST}

CAU 112: AREA 23 HAZARDOUS WASTE TRENCHES - CAS 23-21-02: Area 23 Haz. Waste Trenches (RCRA)

\section{E. FIELD CONCLUSIONS (continued)}

6. Field conclusions/recommendations (continued):

\section{F. CERTIFICATION}

I have conducted an inspection of CAU 112, Area 23 Hazardous Waste Trenches, in accordance with the procedures of the Post-Closure Permit (including the Post-Closure Plan) as recorded on this checklist, attached sheets, and field notes.

Chief Inspector's signature/s/: Glenn Richardson Date: $12 / 15 / 09$

Printed Name:

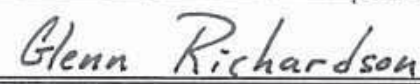

Title: Task

Required Attachments:

1. Field Notes (if any)

2. Photos (or note File Location: S:INTSIER SharelPhotos | CAU $112|2009| 12-15-2009$ CA 4112 Inspections

Distribution: Original - Industrial Sites Project Manager

Copy - Task Manager

\section{G. VERIFICATION}

I have reviewed this checklist and attachments and have verified that it is complete

Signature: /s/: Reed Poderis

Printed Name: Thomas A. Thitete (or designee)

Distribution: Original - Task Manager 


\section{POST-CLOSURE INSPECTION CHECKLIST}

\section{CAU 112: AREA 23 HAZARDOUS WASTE TRENCHES - CAS 23-21-02: Area 23 Haz. Waste Trenches (RCRA)}

\begin{tabular}{|c|c|c|c|}
\hline \multicolumn{2}{|l|}{ Inspection Date and Time: } & Reason for I & Quarterly \\
\hline \multicolumn{2}{|c|}{ Date of Last Post-Closure Inspection: $\quad 12 / 15 / 09$} & \multicolumn{2}{|c|}{ Reason for Last Post-Closure Inspection: Quarterly } \\
\hline \multicolumn{4}{|c|}{ Responsible Entity: NSTec Environmental Restoration, Nevada Test Site, Mercury, Nevada } \\
\hline \multicolumn{4}{|c|}{ Responsible Facility Owner: Thomas A. Thiele, Project Manager, Industrial Sites, Environmental Restoration Project } \\
\hline Chief Inspector: Glenn Richardson & Title: Task & lanager & Organization: Environmental Restoration \\
\hline Assistant Inspector: Dudley Emer & Title: $\operatorname{Sr}$. & ist & Organization: Environmental Restoration \\
\hline
\end{tabular}

A. GENERAL INSTRUCTIONS

- Complete all checklist items.

- If a SHADED BOX is checked, provide detailed information regarding what was found and/or appropriate references to other documents that have the information (e.g., Maintenance Order Form for CAU 92 dated 2/15/2008).

- All documentation must be legible and clear.

\begin{tabular}{|c|c|c|c|}
\hline B. PREPARATION (To be competed prior to site visit) & YES & NO & EXPLANATION (required if shaded box is checked) \\
\hline \multicolumn{4}{|l|}{ 1. Has the Post-Closure Permit been reviewed? } \\
\hline \multicolumn{4}{|l|}{ 2. Has the Post-Closure Permit application been reviewed? } \\
\hline \multicolumn{4}{|l|}{ 3. Has the Post-Closure Plan been reviewed? } \\
\hline \multicolumn{4}{|l|}{ 4. Have the site as-built plans and site base map been reviewed? } \\
\hline \multicolumn{4}{|l|}{ 5. Have the previous inspection reports been reviewed? } \\
\hline \multicolumn{4}{|l|}{ a. Were anomalies or trends detected on previous inspections? } \\
\hline b. Was maintenance performed? & & & $\begin{array}{l}\text { Vegetation was removed on top and a tong } \\
\text { the sides of the waste unit cover in Jan. }\end{array}$ \\
\hline \multicolumn{4}{|l|}{ 6. Have the site maintenance and repair records been reviewed? } \\
\hline $\begin{array}{l}\text { a. If so, has site repair resulted in a change from as-built } \\
\text { conditions? }\end{array}$ & & & NA \\
\hline $\begin{array}{l}\text { b. If yes (to } 6 \mathrm{a} \text { ), are revised as-built plans available that reflect } \\
\text { repair changes? }\end{array}$ & & & NA \\
\hline
\end{tabular}

\section{SITE INSPECTION PREPARATION}

Assemble the following, as needed, to conduct inspections:
a. Camera, digital storage drive, and extra batteries
b. Keys to locks
c. Clipboard
d. Tape measure
e. Radio, pager, etc.
f. Previous Post-Closure Report, Inspection Checklists, repair records, and as-built plans
g. Other miscellaneous support equipment 


\section{POST-CLOSURE INSPECTION CHECKLIST}

CAU 112: AREA 23 HAZARDOUS WASTE TRENCHES - CAS 23-21-02: Area 23 Haz. Waste Trenches (RCRA)

\section{SITE INSPECTION}

- The site inspection is a walking inspection of the entire site including the perimeter and sufficient transects to be able to inspect the entire surface and all features specifically described in this checklist. The checklist should be completed during the site inspection.

- If a shaded box is checked, add detailed comments to document the results of the site inspection. Information provided should be of sufficient detail to enable reconstruction of observations regarding field conditions. Information can take the form of written narrative, sketches, measurements, and annotated site maps, all of which should be placed on additional attachments (if needed) and cross-reference appropriately. Attach the additional pages and number all pages upon completion of the inspection. The completed checklist is part of the field record of the inspection.

- Field notes taken to assist in completion of this checklist will become part of the inspection record. No form is specified for field notes, and additional field notes are not required if the checklist and associated attachments adequately describe site conditions.

1. Adjacent off-site features:

a. Are there any new activities or features in the vicinity that could potentially affect the site (e.g., activities that change the flow of surface water or are encroaching the unit)?

2. Fences, gates, and signs (East Fenced Enclosure):

a. Is there damage to or a break in the fence?

b. Have any fenceposts been damaged or their anchoring weakened?

c. Is the gate intact and functional?

d. Does the gate show evidence of tampering or damage?

e. Was the gate locked?

f. Are any of the use restriction signs damaged or missing?

g. Are all use restriction signs legible?

h. How many use restriction signs need to be replaced?

i. Other?

3. Monuments:

a. Have landfill monuments been disturbed?

b. Do natural processes threaten the integrity of any landfill monuments?

c. Is there excessive vegetation around the landfill monuments?

d. Other?

4. Neutron Access Pads:

a. Have neutron access pads been disturbed?

b. Are well covers for neutron access tubes broken, lost, or otherwise damaged?

c. Other?

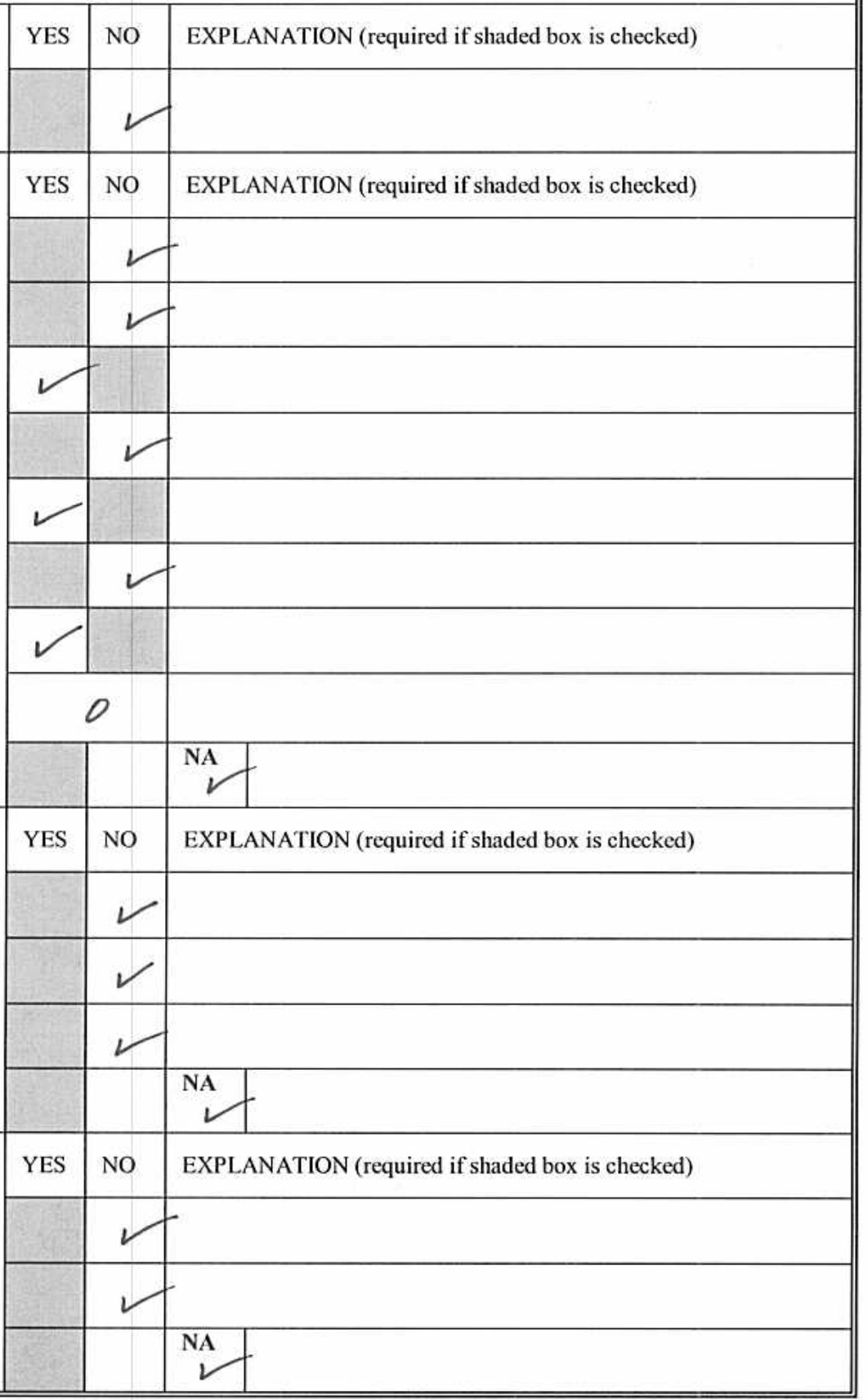




\section{POST-CLOSURE INSPECTION CHECKLIST}

\section{CAU 112: AREA 23 HAZARDOUS WASTE TRENCHES - CAS 23-21-02: Area 23 Haz. Waste Trenches (RCRA)}

5. Waste unit cover:

a. Is there evidence of settling?

b. Is there evidence of cracking?

c. Is there evidence of erosion (wind or water)?

d. Is there evidence of human intrusion onto the cover?

e. Is there evidence of large animal intrusion onto the cover?

f. Is there evidence of animal burrowing?

g. Is vegetation growing on the cover?

h. Is there any obvious damage to the cover or plastic liner?

i. Other (including trash, debris, etc within fenced area)?

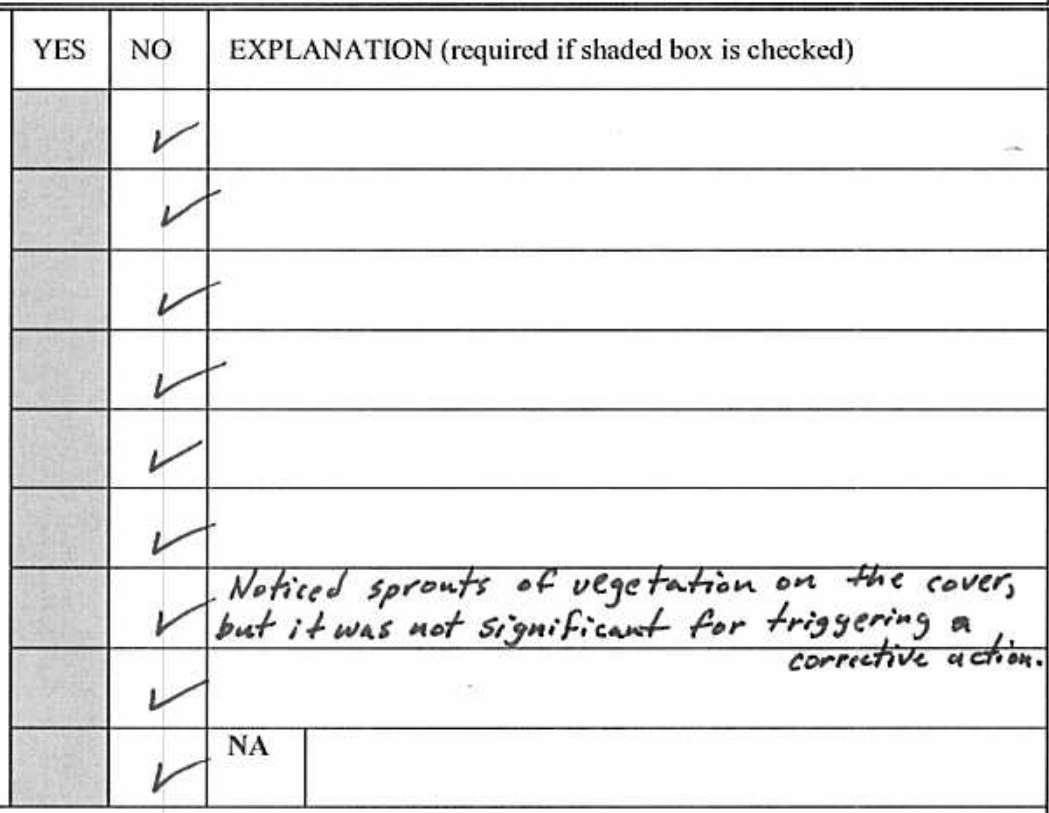

6. Photograph Instructions:

- Photographs should be taken to document maintenance/repair needs at the site. These will be used to plan maintenance/repair activities and are not intended for use in the post-closure annual report.

- Anomalous features or new features (such as changes in adjacent area land use) should be photographed.

- Other photographs are optional.

- A photograph log entry will be made for each photograph taken.

7. Photograph Documentation:

a. Have photographs been taken of the site?

If yes, how many photos were taken?

If yes, has a photographic log been prepared?

\section{E. FIELD CONCLUSIONS}

1. Are more frequent inspections required?

2. Are existing maintenance/repair actions satisfactory?

3. Is other maintenance/repair necessary?

4. Is there obvious damage to the cover or plastic liner?

5. Will necessary repairs change the as-built condition of the unit?

\begin{tabular}{|c|c|c|}
\hline YES & NO & EXPLANATION \\
\hline & & Photos are not required at this CAU. \\
\hline \multicolumn{2}{|c|}{ - } & $N / A$ \\
\hline & & $N / A$ \\
\hline \multirow[t]{4}{*}{ YES } & NO & EXPLANATION (required if shaded box is checked) \\
\hline & $\nu$ & If yes, describe below \\
\hline & $\nu$ & $\begin{array}{l}\text { If "yes", describe below and the Task Manager must complete the } \\
\text { "Follow-up Actions" (not part of checklist) }\end{array}$ \\
\hline & & $\begin{array}{l}\text { If "yes", describe below and the Task Manager must complete the } \\
\text { "Follow-up Actions" (not part of checklist) }\end{array}$ \\
\hline
\end{tabular}

6. Field conclusions/recommendations: Overall sife conditions are great. There is no evidence of damage to the aboveground monuments. The $u R$ signage and fencing is intact and well-maintained. Small vegetation is beginning to sprout on top and along the sides of the rip rap cover, but are not significant enough to warrant a follow-up action. The rip rap 


\section{POST-CLOSURE INSPECTION CHECKLIST}

\section{CAU 112: AREA 23 HAZARDOUS WASTE TRENCHES - CAS 23-21-02: Area 23 Haz. Waste Trenches (RCRA)}

\section{E. FIELD CONCLUSIONS (continued)}

6. Field conclusions/recommendations (continued): cover will be monitored during the next quarterly inspection for advanced vegetation growth. There are no corrective actions necessary at this site.

\section{F. CERTIFICATION}

I have conducted an inspection of CAU 112, Area 23 Hazardous Waste Trenches, in accordance with the procedures of the Post-Closure Permit (including the Post-Closure Plan) as recorded on this checklist, attached sheets, and field notes.

Chief Inspector's signature/s/: Glenn Richardson Date: Printed Name: Gleun Richardson Title: Task Manager

Required Attachments:

1. Field Notes (if any)

2. Photos (or note File Location: S: NTS \ER Share

Distribution: Original - Industrial Sites Project Manager Copy - Task Manager

\section{G. VERIFICATION}

I have reviewed this checklist and attachments and have verified that it is complete.

Signature: /s/: Reed Poderis

Printed Name: Thomas A. Thiele (or designee)

Distribution: Original - Task Manager 


\section{POST-CLOSURE INSPECTION CHECKLIST}

CAU 112: AREA 23 HAZARDOUS WASTE TRENCHES - CAS 23-21-02: Area 23 Haz. Waste Trenches (RCRA)

\begin{tabular}{|c|c|c|}
\hline Inspection Date and Time: $6 / 23 / 10$ & $12 ; 10$ & Puarterli. \\
\hline Date of Last Post-Closure Inspection: $\quad 3 / 1$ & 10 & Reason for Last Post-Closure Inspection: \\
\hline
\end{tabular}

Responsible Entity: NSTec Environmental Restoration, Nevada Test Site, Mercury, Nevada

Responsible Facility Owner: Thomas A. Thiele, Project Manager, Industrial Sites, Environmental Restoration Project

\begin{tabular}{|c|c|c|}
\hline Chief Inspector: Ge ww R & 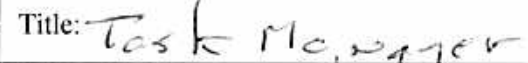 & Organization: Environmental Restoration \\
\hline 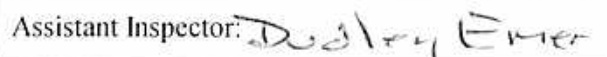 & Title: $<$ & Organization: Environmental Restoration \\
\hline
\end{tabular}

\section{A. GENERAL INSTRUCTIONS}

- Complete all checklist items.

- If a SHADED BOX is checked, provide detailed information regarding what was found and/or appropriate references to other documents that have the information (e.g., Maintenance Order Form for CAU 92 dated 2/15/2008).

- All documentation must be legible and clear.

\begin{tabular}{|c|c|c|c|c|}
\hline B. PREPARATION (To be competed prior to site visit) & YES & NO & \multicolumn{2}{|c|}{ EXPLANATION (required if shaded box is checked) } \\
\hline \multicolumn{5}{|l|}{ 1. Has the Post-Closure Permit been reviewed? } \\
\hline \multicolumn{5}{|l|}{ 2. Has the Post-Closure Permit application been reviewed? } \\
\hline \multicolumn{5}{|l|}{ 3. Has the Post-Closure Plan been reviewed? } \\
\hline \multicolumn{5}{|l|}{ 4. Have the site as-built plans and site base map been reviewed? } \\
\hline \multicolumn{5}{|l|}{ 5. Have the previous inspection reports been reviewed? } \\
\hline \multicolumn{5}{|l|}{ a. Were anomalies or trends detected on previous inspections? } \\
\hline \multicolumn{5}{|l|}{ b. Was maintenance performed? } \\
\hline \multicolumn{5}{|l|}{ 6. Have the site maintenance and repair records been reviewed? } \\
\hline $\begin{array}{l}\text { a. If so, has site repair resulted in a change from as-built } \\
\text { conditions? }\end{array}$ & & & NA & \\
\hline $\begin{array}{l}\text { b. If yes (to } 6 a \text { ), are revised as-built plans available that reflect } \\
\text { repair changes? }\end{array}$ & & & NA & \\
\hline
\end{tabular}

\section{SITE INSPECTION PREPARATION}

Assemble the following, as needed, to conduct inspections:
a. Camera, digital storage drive, and extra batteries
b. Keys to locks
c. Clipboard
d. Tape measure
e. Radio, pager, etc.
f. Previous Post-Closure Report, Inspection Checklists, repair records, and as-built plans
g. Other miscellaneous support equipment 


\section{POST-CLOSURE INSPECTION CHECKLIST}

\section{CAU 112: AREA 23 HAZARDOUS WASTE TRENCHES - CAS 23-21-02: Area 23 Haz. Waste Trenches (RCRA)}

\section{SITE INSPECTION}

- The site inspection is a walking inspection of the entire site including the perimeter and sufficient transects to be able to inspect the entire surface and all features specifically described in this checklist. The checklist should be completed during the site inspection.

- If a shaded box is checked, add detailed comments to document the results of the site inspection. Information provided should be of sufficient detail to enable reconstruction of observations regarding field conditions. Information can take the form of written narrative, sketches, measurements, and annotated site maps, all of which should be placed on additional attachments (if needed) and cross-reference appropriately. Attach the additional pages and number all pages upon completion of the inspection. The completed checklist is part of the field record of the inspection.

- Field notes taken to assist in completion of this checklist will become part of the inspection record. No form is specified for field notes, and additional field notes are not required if the checklist and associated attachments adequately describe site conditions.

1. Adjacent off-site features:

a. Are there any new activities or features in the vicinity that could potentially affect the site (e.g., activities that change the flow of surface water or are encroaching the unit)?

2. Fences, gates, and signs (East Fenced Enclosure):

a. Is there damage to or a break in the fence?

b. Have any fenceposts been damaged or their anchoring weakened?

c. Is the gate intact and functional?

d. Does the gate show evidence of tampering or damage?

e. Was the gate locked?

f. Are any of the use restriction signs damaged or missing?

g. Are all use restriction signs legible?

h. How many use restriction signs need to be replaced?

i. Other?

3. Monuments:

a. Have landfill monuments been disturbed?

b. Do natural processes threaten the integrity of any landfill monuments?

c. Is there excessive vegetation around the landfill monuments?

d. Other?

4. Neutron Access Pads:

a. Have neutron access pads been disturbed?

b. Are well covers for neutron access tubes broken, lost, or otherwise damaged?

c. Other?

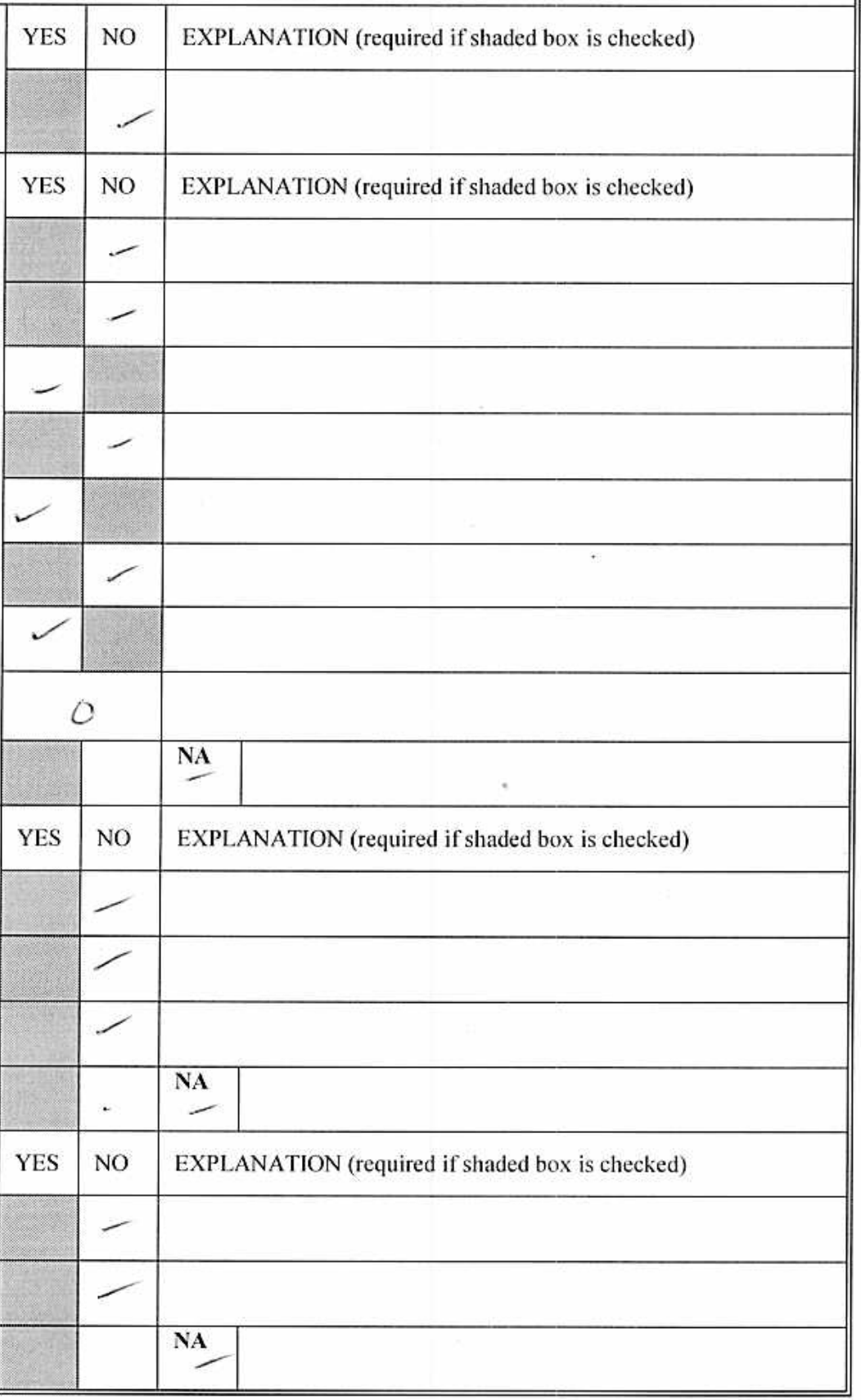




\section{POST-CLOSURE INSPECTION CHECKLIST}

\section{CAU 112: AREA 23 HAZARDOUS WASTE TRENCHES - CAS 23-21-02: Area 23 Haz. Waste Trenches (RCRA)}

5. Waste unit cover:

a. Is there evidence of settling?

b. Is there evidence of cracking?

c. Is there evidence of erosion (wind or water)?

d. Is there evidence of human intrusion onto the cover?

e. Is there evidence of large animal intrusion onto the cover?

f. Is there evidence of animal burrowing?

g. Is vegetation growing on the cover?

h. Is there any obvious damage to the cover or plastic liner?

i. Other (including trash, debris, etc within fenced area)?

\begin{tabular}{|c|c|c|}
\hline YES & NO & EXPLANATION (required if shaded box is checked) \\
\hline & & \\
\hline & - & \\
\hline & - & \\
\hline & & \\
\hline & & \\
\hline & & \\
\hline & & 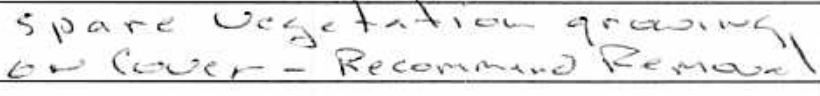 \\
\hline & & NA \\
\hline
\end{tabular}

6. Photograph Instructions:

- Photographs should be taken to document maintenance/repair needs at the site. These will be used to plan maintenance/repair activities and are not intended for use in the post-closure annual report.

- Anomalous features or new features (such as changes in adjacent area land use) should be photographed.

- Other photographs are optional.

- A photograph log entry will be made for each photograph taken.

7. Photograph Documentation:

a. Have photographs been taken of the site?

If yes, how many photos were taken?

If yes, has a photographic log been prepared?

\section{E. FIELD CONCLUSIONS}

1. Are more frequent inspections required?

2. Are existing maintenance/repair actions satisfactory?

3. Is other maintenance/repair necessary?

4. Is there obvious damage to the cover or plastic liner?

5. Will necessary repairs change the as-built condition of the unit?

6. Field conclusions/recommendations:

\begin{tabular}{|c|c|c|}
\hline YES & NO & EXPLANATION \\
\hline
\end{tabular}

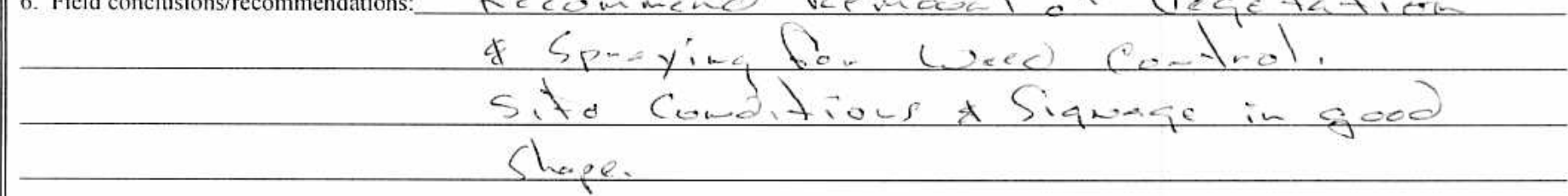




\section{POST-CLOSURE INSPECTION CHECKLIST}

CAU 112: AREA 23 HAZARDOUS WASTE TRENCHES - CAS 23-21-02: Area 23 Haz. Waste Trenches (RCRA)

\section{E. FIELD CONCLUSIONS (continued)}

6. Field conclusions/recommendations (continued):

\section{F. CERTIFICATION}

1 have conducted an inspection of CAU 112, Area 23 Hazardous Waste Trenches, in accordance with the procedures of the Post-Closure Permit (including the Post-Closure Plan) as recorded on this checklist, attached sheets, and field notes.

Chief Inspector's Signature:s/: Glenn Richardson Date: Printed Name: Glenn Richardson

$$
6 / 23 / 10
$$

Title: Task Manager

\section{Required Attachments:}

1. Field Notes (if any)

2. Photos (or note File Location: S:INTS\ER Share $\backslash$ Photos $\backslash$ CA $4112 \backslash$ 2010 $106-23-2010$ inspection - Veguncover

Distribution: Original - Industrial Sites Project Manager

$$
\text { Copy - Task Manager }
$$

\section{G. VERIFICATION}

I have reviewed thio ghecklist and attachments and have verified that it is complete.

Signature: /s/: Reed Poderis

Printed Name/ Thomas A. Thiele (or designee)

Distribution: Original - Task Manager 


\section{POST-CLOSURE INSPECTION CHECKLIST}

\section{CAU 112: AREA 23 HAZARDOUS WASTE TRENCHES - CAS 23-21-02: Area 23 Haz. Waste Trenches (RCRA)}

\begin{tabular}{|l|l|}
\hline Inspection Date and Time: $9 / 8 / 10 \quad$ 12:25 PM & Reason for Inspection: Quarterly \\
\hline Date of Last Post-Closure Inspection: $6 / 23 / 10$ & Reason for Last Post-Closure Inspection: Quarterly
\end{tabular}

Responsible Entity: NSTec Environmental Restoration, Nevada Test Site, Mercury, Nevada

Responsible Facility Owner: Thomas A. Thiele, Project Manager, Industrial Sites, Environmental Restoration Project

\begin{tabular}{|l|l|l|}
\hline Chief Inspector: Glenen Kichardson & Title: Task Manager & Organization: Environmental Restoration \\
\hline Assistant Inspector: None & Title: & Organization: Environmental Restoration \\
\hline \hline
\end{tabular}

A. GENERAL INSTRUCTIONS

- Complete all checklist items.

- If a SHADED BOX is checked, provide detailed information regarding what was found and/or appropriate references to other documents that have the information (e.g., Maintenance Order Form for CAU 92 dated 2/15/2008).

- All documentation must be legible and clear.

\section{B. PREPARATION (To be competed prior to site visit)}

1. Has the Post-Closure Permit been reviewed?

2. Has the Post-Closure Permit application been reviewed?

3. Has the Post-Closure Plan been reviewed?

4. Have the site as-built plans and site base map been reviewed?

5. Have the previous inspection reports been reviewed?

a. Were anomalies or trends detected on previous inspections?

b. Was maintenance performed?

6. Have the site maintenance and repair records been reviewed?

a. If so, has site repair resulted in a change from as-built conditions?

b. If yes (to 6a), are revised as-built plans available that reflect repair changes?

\begin{tabular}{|l|l|l||}
\hline YES & NO & EXPLANATION (required if shaded box is checked) \\
\hline & & \\
\hline & & \\
\hline & & \\
\hline the side slope of the cover in Ang. 2010.
\end{tabular}

\section{SITE INSPECTION PREPARATION}

Assemble the following, as needed, to conduct inspections:

a. Camera, digital storage drive, and extra batteries

b. Keys to locks

c. Clipboard

d. Tape measure

e. Radio, pager, etc.

f. Previous Post-Closure Report, Inspection Checklists, repair records, and as-built plans

g. Other miscellaneous support equipment 


\section{POST-CLOSURE INSPECTION CHECKLIST}

CAU 112: AREA 23 HAZARDOUS WASTE TRENCHES - CAS 23-21-02: Area 23 Haz. Waste Trenches (RCRA)

\section{SITE INSPECTION}

- The site inspection is a walking inspection of the entire site including the perimeter and sufficient transects to be able to inspect the entire surface and all features specifically described in this checklist. The checklist should be completed during the site inspection.

- If a shaded box is checked, add detailed comments to document the results of the site inspection. Information provided should be of sufficient detail to enable reconstruction of observations regarding field conditions. Information can take the form of written narrative, sketches, measurements, and annotated site maps, all of which should be placed on additional attachments (if needed) and cross-reference appropriately. Attach the additional pages and number all pages upon completion of the inspection. The completed checklist is part of the field record of the inspection.

- Field notes taken to assist in completion of this checklist will become part of the inspection record. No form is specified for field notes, and additional field notes are not required if the checklist and associated attachments adequately describe site conditions.

1. Adjacent off-site features:

a. Are there any new activities or features in the vicinity that could potentially affect the site (e.g., activities that change the flow of surface water or are encroaching the unit)?

2. Fences, gates, and signs (East Fenced Enclosure):

a. Is there damage to or a break in the fence?

b. Have any fenceposts been damaged or their anchoring weakened?

c. Is the gate intact and functional?

d. Does the gate show evidence of tampering or damage?

e. Was the gate locked?

f. Are any of the use restriction signs damaged or missing?

g. Are all use restriction signs legible?

h. How many use restriction signs need to be replaced?

i. Other?

3. Monuments:

a. Have landfill monuments been disturbed?

b. Do natural processes threaten the integrity of any landfill monuments?

c. Is there excessive vegetation around the landfill monuments?

d. Other?

4. Neutron Access Pads:

a. Have neutron access pads been disturbed?

b. Are well covers for neutron access tubes broken, lost, or otherwise damaged?

c. Other?

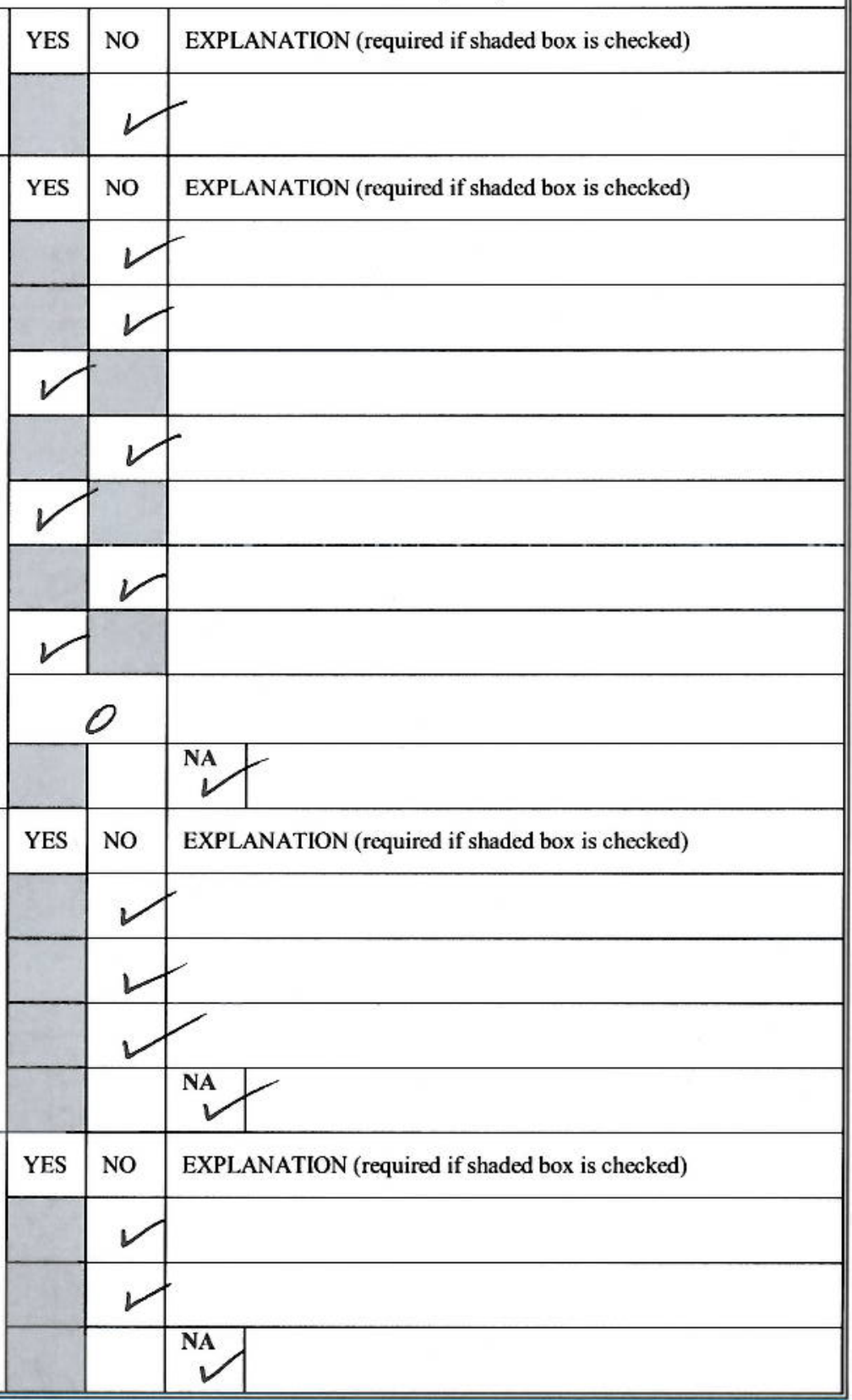

Page 2 of 4 


\section{POST-CLOSURE INSPECTION CHECKLIST}

\section{CAU 112: AREA 23 HAZARDOUS WASTE TRENCHES - CAS 23-21-02: Area 23 Haz. Waste Trenches (RCRA)}

5. Waste unit cover:

a. Is there evidence of settling?

b. Is there evidence of cracking?

c. Is there evidence of erosion (wind or water)?

d. Is there evidence of human intrusion onto the cover?

e. Is there evidence of large animal intrusion onto the cover?

f. Is there evidence of animal burrowing?

g. Is vegetation growing on the cover?

h. Is there any obvious damage to the cover or plastic liner?

i. Other (including trash, debris, etc within fenced area)?

\begin{tabular}{|l|l|l|}
\hline YES & NO & EXPLANATION (required if shaded box is checked) \\
\hline & & \\
\hline & & \\
\hline & & \\
\hline & & \\
\hline & & \\
\hline
\end{tabular}

6. Photograph Instructions:

- Photographs should be taken to document maintenance/repair needs at the site. These will be used to plan maintenance/repair activities and are not intended for use in the post-closure annual report.

- Anomalous features or new features (such as changes in adjacent area land use) should be photographed.

- Other photographs are optional.

- A photograph log entry will be made for each photograph taken.

7. Photograph Documentation:

a. Have photographs been taken of the site?

If yes, how many photos were taken?

If yes, has a photographic $\log$ been prepared?

\section{E. FIELD CONCLUSIONS}

1. Are more frequent inspections required?

2. Are existing maintenance/repair actions satisfactory?

3. Is other maintenance/repair necessary?

4. Is there obvious damage to the cover or plastic liner?

5. Will necessary repairs change the as-built condition of the unit?

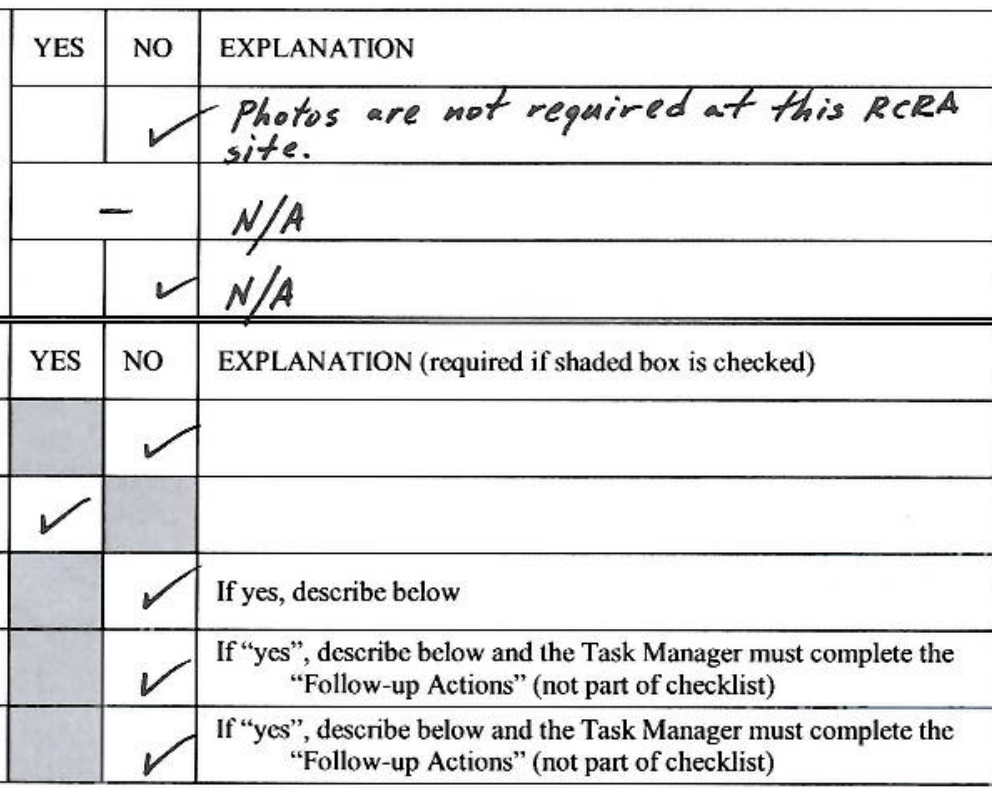

6. Field conclusions/recommendations: The use restriction signage and fencing are in excellent condition. There was no indication of subsidence or settling on the rip-rap cover. Also, there wasno evidince of new vegetation growth on the top and/or side slope of the cover. The aboveground monuments are not damaged and appear to be in 


\section{POST-CLOSURE INSPECTION CHECKLIST}

CAU 112: AREA 23 HAZARDOUS WASTE TRENCHES - CAS 23-21-02: Area 23 Haz. Waste Trenches (RCRA)

E. FIELD CONCLUSIONS (continued)

6. Field conclusions/recommendations (continued): good condifion. There are no issues or concerns at this site.

\section{F. CERTIFICATION}

I have conducted an inspection of CAU 112, Area 23 Hazardous Waste Trenches, in accordance with the procedures of the Post-Closure Permit (including the Post-Closure Plan) as recorded on this checklist, attached sheets, and field notes.

\begin{tabular}{l} 
Chief Inspector's signature:s/: Glenn Richardsolpate: $9 / 8 / 10$ \\
Printed Name: Glenn Richardson \\
\hline
\end{tabular}

Required Attachments:

1. Field Notes (if any)

2. Photos (or note File Location: S: $\backslash$ NTS \ER Share )

Distribution: Original - Industrial Sites Project Manager

Copy - Task Manager

\section{G. VERIFICATION}

I have review/ad this chgcklist and attachments and have verified that it is complete.

Signature: /s/: Reed Poderis

Printed Name. Thomas A. Thiele (or designee)

Distribution: Original - Task Manager 
RCRA Post-Closure Report

Revision: 0

Date: January 2011

APPENDIX B.

FIELD NOTES 
RCRA Post-Closure Report

Revision: 0

Date: January 2011

\section{THIS PAGE INTENTIONALLY LEFT BLANK}


RCRA Post-Closure Report

Revision: 0

Date: January 2011

\section{DECEMBER 15, 2009}


RCRA Post-Closure Report

Revision: 0

Date: January 2011

\section{THIS PAGE INTENTIONALLY LEFT BLANK}


RUS

BOOK NO.

Work continued from Page.

RCRA POST. CLOSURE Inspections - 12/15/09

Personnel: Ted Zaferatos (NDEP)

G. Richardson (NSTec-TM)

76. Doyle (NSTec-Sr. Scientist)

Scope: Perform quarterly post closure site inspections for CAUs: $92,110,+112$ Perform semiannual post closure site inspections for CAU 90

Weather: Clear, Light Breeze, Mid HOs

Equipment: Camera, Measuring Ruler

PPE: Standard Level D (No Hard Hats necessary)

9:00AM - Leaving Mercury in route to Area 2 Bitcutter (CAU 90)

9:40 AM - Arrived Q CAU 90 - Area 2 Bitcutter Containment

A tailgate safety briefing was conducted to discuss potential hazards associated with slips/trips/ falls. Biological hazards and cold stress conditions were also mentioned. A site inspection was performed that confirmed the UR signs and chain link fencing were in excellent condition. There was no evidence of animal burrowing or vegetation within the fenced area or around the concrete monument pad. In addition, there was no evidence of settling on the soil cover. Photos. were taken as required. Leaving CAU 90 at 9:55 AM.

10:15 AM - Arrived @ CAU $110-u-3 a x / b 1$

Inspected the site to confirm the fencing, UR signage, and vegetative cover were in good condition. Noticed various animal burrows that warranted a follow-up action. Also, discovered SCIENTIFIC BINDERY PRODUCTIONS CHICAgO 60605 Made in USA

Work continued to Page signature /s/: Glenn Richardson

DATE

DISCLOSED TO AND UNDERSTOOD BY

DATE

WITNESS

$12 / 15 / 09$ 
206 TITLE

Work continued from Page
PROJECT NO.

BOOK NO.

subsidence greater than $6 \mathrm{in}$. deep that extended from 3-8ft. in approx. 5 different areas along the East edge of the cover. subsidence repairs are required within 60 days. In addition, any excess soil available will be used to backfill the animal burrows. There was no evidence of damage to the at-grade concrete monuments on the waste unit cover. Repairs will be coordinated with engineering support. Required photos were taken of the site and subsidence areas.

11:15 AM - Arrived @ CAU 92 - Area 6 Decon Pond

Performed a site inspection to discover damage to the wave barriers on the east and NE side of the chain-linkfence. Repairs are necessary and will be completed within 60 days. There was some standing water along the north and SE edge of the cover, but nothing was actually on the cover surface to warrant a followup action. The $U R$ signage and radiological signage were in great condition. No evidence of settling on the cover or vegetation. The cover was in a good condition with no animal burrows. The surface grade monuments showed no sign of damage. Theosite fencing was secured and lock attached to the entrance gate. Photos were taken as required.

12:00 PM - Arrived C CAU 112 - Area 23 Haze. Waste Trenches A drive-around inspection was performed where we noticed new vegetation growth on top of tie rip rap rock cover and along the side slopes. The vegetation will be removed or an herbicide spray will be applied within 60 days. The UR signage and fencing were in good condition. The aboveground monuments were sturdy and intact. The site was well-securedi. 12:05 PM - End of PCM RCRA Inspections /s/: Glenn Richardson signature /S/: Glenn Richardson

Work continued to Page

DATE

$12 / 15 / 09$ 
RCRA Post-Closure Report

Revision: 0

Date: January 2011

MARCH 17, 2010 
RCRA Post-Closure Report

Revision: 0

Date: January 2011

\section{THIS PAGE INTENTIONALLY LEFT BLANK}


TITLE

PROJECT NO.

207

Work continued from Page

BOOK NO.

RCRA Post Closure Inspections - 3/17/10

Personnel: Kevin Cable (NNSA)

Ted Zaferatos (NDEP)

5 Glenn Richardson, Dudley Elmer, Dave Anderson (NSTeC)
Task Mgr.
Biologist

Scope: Perform quarterly post closure site inspections for CAMs: 93110 , and 112 Perform semiannual post closure site inspections for CAU 91.

Weather: High 50s-Low LOs, Clear w/ Sunny Skies PPE: Standard Level (No hard hats necessary)

9:45 AM - Leaving Mercury in route to Area 3 u3fi Injection Well (CAM 91) 10:25AM-Arrived e CAM 91 - Area 3 uzi Injection Well

Conducted a tailgate safety briefing to discuss common OSHA hazards such as slips/trips/falls, biological hazards, and heat stress conditions to reinforce hydration. We also discussed radiological hazards

A site inspection was performed to confirm the UR signage, chain-link fencing, and aboveground monument is in excellent condition. There was no vegetation inside the fenced area or specifically around the concrete pad. There was no evidence of animal burrows in the area. Overall conditions at this site were great. There are no corrective actions necessary. 10:45 AM-Arrived @ CAU 110 -Area 3 WMD u-3ax/b1 (CAM 110) We met Dave Anderson w/ Ecological Services, to observe the new vegetation that he and his team reseeded and replanted on the east portion of the soil cover. Inspection results confirmed the UR signage, fencing, and surface grade monuments are in excellent condition. The subsidence repairs that were done in Jan. 2010 are stable and in good condition. No evidence of new SCIENTIFIC BINDERY PRODUCTIONS CHICAGO 60605 Made in USA

Work continued to Page 208

Signature /s/: Glenn Richardson

DISCLOSED TO AND UNDERSTOOD BY
DATE

$3 / 17 / 10$ 
208 TITLE

Work continued from Page _207
PROJECT NO.

BOOK NO.

subsidence features or settling. The new vegetation that was reestablished on the east portion of the cover was protected by tempera fencing to prevent intrusion by small animals. There were some small animal burrows noticed at the site, but were not determined to be significs. 5 enough to warrant a corrective action. There were no issues or con at this site.

11:50AM-Arrived. CAU 92 - Area 6 Deon Pond

The UR signage, radiological signage, fencing, and surface grade monument were in good condition. Since repairs were made to the wave barriers in $10 \mathrm{Jan} .2010$, there were no breaches noticed. There was no evidence of vegetation, subsidence, or settling on the waste unit cover. Standing water was noticed inside the fence line along the north and sw edges of the cover, but no standing water was observed on the actual cover. The are no issues warranting followup action at this site.

15 12:35PM-Arrived@CAU112-Area 23 Hazardous Waste Trenches

A drive-around inspection was performed to confirm the UR signage, fencing, and aboveground monuments were in great condition. The ace gate was locked and secured upon arrival. There was some small evidence of new vegetation sprouting on top and along the slope of 20 the rip rap cover, but was not significant enough to warrant a followup corrective action. The rip rap cover will be monitored for an advanced stage of vegetation growth during the next quarterly inspection period. This site has no concerns or issues.

12:40 PM - End of PCM RCRA Inspections 25

/s/: Glenn Richardson

$3 / 17 / 10$

SCIENTIFIC BINDERY PRODUCTIONS CHICAGO 60605 Made in USA

SIgNature /s/: Glenn Richardson
Work continued to Page

DATE 
RCRA Post-Closure Report

Revision: 0

Date: January 2011

JUNE 23, 2010 
RCRA Post-Closure Report

Revision: 0

Date: January 2011

\section{THIS PAGE INTENTIONALLY LEFT BLANK}


TITLE

Work continued from Page
PROJECT NO.

BOOK NO.

7

RCRA Post Closure Inspections - $6 / 23 / 10$

Personnel: Tiffany Lantow (NNSA)

Glenn Richardson (NSTec) - Task Mgr.

5

Dudley Ewer (NSTec) - Sr. Scientist

Scope: Perform quarterly post closure site inspections at CAUs: 92, 110, ,'ll Perform semiannual post closure site inspections at CAU 90 .

10 Weather: High 90s - Low 100s, Sunny, Clear Skies PPE: Standard Level D (No hardhats required)

9:25 AM - Leaving Mercury in route to Area 2 Bifcutter (CAU 90) 10:05AM-Arrived@CAM90 and conducted a brief tailgate 15 safety meeting to discuss common OSHA hazards, heat stress conditions and biological hazards. Radiological hazards will be covered before accessing CAUl $11043 \mathrm{ax} / \mathrm{bl}$.

10:15 AM - Performed a site inspection $C$ CAL 90 to confirm the UR signage, chain-link fencing, and concrete pads are in excellent condition. There was no evidence of animal burrows inside the fenced area. Noticed no vegetation growth around the concrete pad or inside the fenced area. The overall site conditions were excellent with no follow-up actions necessary. Photo documentation was taken at the site.

25 10:35 AM - Arrived $C$ CAU 110 - Area 3 wMD 4-3ax/bl to perform an inspection. Radiological hazards were briefed at this site prior to entry since it is within an URMA. The UR signage and radiological postings were intact and legible. The outer plastic snow fence and gate was www.scientificbindery88yrs.com

Work continued to Page 8 signature /s/: Glenn Richardson

DATE

DISCLOSED TO AND UNDERSTOOD BY

DATE

WITNESS

$6 / 23 / 10$ 
8

TITLE

PROJECT NO.

Work continued from Page $\quad 7$

BOOK NO.

not stable/upright and was in need of repair. This snow fence is not part of the primary fence surrounding the RCRA site, but was established to provide direct access to u-3ax/bl during RWMS operations in Area 3. As a best meat practice, the snow fence and gate will be repaired. The $U R$ fencing around the site is in great condition. There is no evidence of settling or subsidence. The repairs that were done in Jan. 2010 are stable and in great condition. The new vegetation that was reseeded and replanted appears to be growing successfully. Even though there are a few small animal burrows, there is no evidence of significant animal intrusion warranting a followup action by Nistec ecological services. photo documentation was taken. There are no issues warranting immediate action per the permit requirements. The snow fence repairs will be performed as a $B M P$.

11:25 AM - Arrived e CAK 92 -Area 6 Decon Pond to perform an inspection. The UR signage was in good condition along with the radiological signage. Noticed the west section of fencing was detached from the fence clamps in certain areas and in need of repair. Also, there was new vegetation growth along the west, south, and north edges of the waste unit cover. The vegetation will require removal and/or herbicide application. There was no evidence of animal intrusion, subsidence, or settling on the cover. The wave barriers along the southwest section of fencing were displaced and in need of repair replacement. The issues associated with the fencing could be caused by high winds within the general area. All corrective actions noted will be addressed and resolved within the 60-day regulatory compliance period. Photos were taken to document the inspection and repair/maintenance needs.

scientificbindery88yrs.com

GNATURE /s/: Glenn Richardson

Work continued to Page 9

DATE 
TITLE

Work continued from Page $\quad 8$
PROJECT NO.

BOOK NO.

$$
\begin{aligned}
& \text { 12:10 PM - Arrived } \odot \text { CAU } 112 \text { - Area } 23 \text { waste Trenches to perform } \\
& \text { an inspection. During the drive arount inspection, noticed new } \\
& \text { vegetation sprouting through the rip rap on top and alougthe }
\end{aligned}
$$

sides of the cover. As a corrective action, vegetation removal and/or herbicide application will occur within sixty days. The aboveground monuments and signage are in goad condition. There was no evidence of subsidence or settling on the cover. Photos were tuken to document the maintenance/repairneeds.

\section{/s/: Glenn Richardson}

DATE $6 / 23 / 10$ 
RCRA Post-Closure Report

Revision: 0

Date: January 2011

\section{THIS PAGE INTENTIONALLY LEFT BLANK}


RCRA Post-Closure Report

Revision: 0

Date: January 2011

\section{SEPTEMBER 8, 2010}


RCRA Post-Closure Report

Revision: 0

Date: January 2011

\section{THIS PAGE INTENTIONALLY LEFT BLANK}


10 TITLE

Work continued from Page
PROJECT NO.

BOOK NO.

RCRA Post Closure Inspections - 9/8/10

Personnel: Tiffany Lantow (NNSA)

Ted Zaferatos (NDEP)

5

Glenn Richardson (NSTec) - Task Manager

Scope: Perform quarterly post closure site inspections at CAUs: 孫 92 , 110,0112 Perform semiannual post closure site inspections at CAU 91.

10 PPE: Standard Level D (No hard hats required) Weather: High 90s, Sunny, Windy

9:43 AM Departing from Mercury in route to Area 3 4-3fi Injection Well. ( CAul $(91)$ 10:25 AM Arrived @ CAM al U3fi Injection Well site. A brief tailgate safety meeting was held to discuss slips/trips/falls, heat stress conditions, and also alertness towards biological hazards. The UR signage and chain-link fencing were in excellent condition. There was no evidence of animal burrows, settlingij or subsidence on the cover. However, a large amount of vegetation had grown on the cover and around the concrete pad. Vegetation removal and/or herbicide application is necessary. The aboveground monument was in good condition and had no indication of damage. Photo documentation was taken. Followup actions are required within 60 days.

Departed from the site $C$ 10:40 AM in route to CAM 110 U3ax/bl 10:50 AM Arrived (2) CAL 110 Area 3 wMD U-3ax/bl. Overall site 25 conditions were great. Radiological hazards were briefed prior to performing the site inspection. The vegetation on the cover appeared to be in very good condition, especially those areas that were reseeded and replanted. There was no evidence

www.scientificbindery88yrs.com

signature /s/: Glenn Richardson

Work continued to Page

DISCLOSED TO AND UNDERSTOOD BY

DATE

WITNESS

DATE

$9 / 8 / 10$ 
of cracks, subsidence, or settling on the cover. There were small animal burrows noticed, but nothing significant to warrant a followup action. The at-grade monuments and surroundin fencing were in good condition. The UR signage was intact and legible; however, the radiological signage on the north side of the fence was loose and needs to be tightened. Rud-con will be informed about this follownp action. Photos were taken of the site and to doenment maintenance needs. Depurted from the site@11:25AM in route to CAM 92 Decon 11:40AM Arrived@ CAU 92 Area6 Decon Pond to perform an inspection. The UR signage and chain-lint fencing are in excellent condition. All radiological postings are intact and legible. Diseovered new vegetation spronting along the south edge of the cover. The sumface grade monuments remain in good condition. There weret subsidence cracks or settling noticed on the cover. Repairs to the wave barriers resulting from the previous quarterly inspection are wellmaintained. Photo documentation was taken. A follow-up action is necessary to remove the new vegetation sprouting 20 on the south edge of the cover. Departed from the site (11:55 AM in route to CAU 112 Haz. Waste Trenches 12:25 PM Hrrived @ CAUl12 Area 23 Haz. Waste Trenches. A drive-around inspection was performed to find no issues or concerns. The aboveground monumeni's are sturdy and intact. There is no evidence of vegetation growth on or along the sides of the rip-rap cover. There are no follown actions at this site.

12:35 PM End of Inspections

www.scientificbindery88vrs.com

signature /S/: Glenn Richardson

Work continued to Page 
RCRA Post-Closure Report

Revision: 0

Date: January 2011

\section{Appendix C.}

\section{PhOtOGRAPHS}


RCRA Post-Closure Report

Revision: 0

Date: January 2011

\section{THIS PAGE INTENTIONALLY LEFT BLANK}




\section{Photograph Log}

\begin{tabular}{|c|c|c|c|}
\hline $\begin{array}{l}\text { CORRECTIVE } \\
\text { ACTION UNIT } \\
\end{array}$ & DATE & $\begin{array}{c}\text { PHOTOGRAPH } \\
\text { NUMBER } \\
\end{array}$ & DESCRIPTION \\
\hline \multirow{12}{*}{90} & \multirow{6}{*}{$12 / 15 / 2009$} & 1 & West Unit Facing North \\
\hline & & 2 & West Unit Facing East \\
\hline & & 3 & West Unit Facing South \\
\hline & & 4 & East Unit Facing South \\
\hline & & 5 & East Unit Facing West \\
\hline & & 6 & East Unit Facing North \\
\hline & \multirow{6}{*}{ 06/23/2010 } & 7 & West Unit Facing North \\
\hline & & 8 & West Unit Facing East \\
\hline & & 9 & West Unit Facing South \\
\hline & & 10 & East Unit Facing South \\
\hline & & 11 & East Unit Facing West \\
\hline & & 12 & East Unit Facing North \\
\hline \multirow{20}{*}{91} & \multirow{10}{*}{$03 / 17 / 2010$} & 13 & Inside Facing North \\
\hline & & 14 & Inside Facing East \\
\hline & & 15 & Inside Facing South \\
\hline & & 16 & Inside Facing West \\
\hline & & 17 & Surface Monument Facing North \\
\hline & & 18 & Surface Monitoring Well Facing South \\
\hline & & 19 & Outside Facing North \\
\hline & & 20 & Outside Facing East \\
\hline & & 21 & Outside Facing South \\
\hline & & 22 & Outside Facing West \\
\hline & \multirow{10}{*}{ 09/08/2010 } & 23 & Inside Facing North \\
\hline & & 24 & Inside Facing East \\
\hline & & 25 & Inside Facing South \\
\hline & & 26 & Inside Facing West \\
\hline & & 27 & Surface Monument Facing North \\
\hline & & 28 & Surface Monitoring Well Facing South \\
\hline & & 29 & Outside Facing North \\
\hline & & 30 & Outside Facing East \\
\hline & & 31 & Outside Facing South \\
\hline & & 32 & Outside Facing West \\
\hline
\end{tabular}




\section{Photograph Log, CONTINUED}

\begin{tabular}{|c|c|c|c|}
\hline $\begin{array}{l}\text { CORRECTIVE } \\
\text { ACTION UNIT } \\
\end{array}$ & DATE & $\begin{array}{c}\text { PHOTOGRAPH } \\
\text { NUMBER } \\
\end{array}$ & DESCRIPTION \\
\hline \multirow{32}{*}{92} & \multirow{8}{*}{$12 / 15 / 2009$} & 33 & Inside Facing North \\
\hline & & 34 & Inside Facing East \\
\hline & & 35 & Inside Facing South \\
\hline & & 36 & Inside Facing West \\
\hline & & 37 & Outside Facing North \\
\hline & & 38 & Outside Facing East \\
\hline & & 39 & Outside Facing South \\
\hline & & 40 & Outside Facing West \\
\hline & \multirow{8}{*}{ 03/17/2010 } & 41 & Inside Facing North \\
\hline & & 42 & Inside Facing East \\
\hline & & 43 & Inside Facing South \\
\hline & & 44 & Inside Facing West \\
\hline & & 45 & Outside Facing North \\
\hline & & 46 & Outside Facing East \\
\hline & & 47 & Outside Facing South \\
\hline & & 48 & Outside Facing West \\
\hline & \multirow{8}{*}{ 06/23/2010 } & 49 & Inside Facing North \\
\hline & & 50 & Inside Facing East \\
\hline & & 51 & Inside Facing South \\
\hline & & 52 & Inside Facing West \\
\hline & & 53 & Outside Facing North \\
\hline & & 54 & Outside Facing East \\
\hline & & 55 & Outside Facing South \\
\hline & & 56 & Outside Facing West \\
\hline & \multirow{8}{*}{ 09/08/2010 } & 57 & Inside Facing North \\
\hline & & 58 & Inside Facing East \\
\hline & & 59 & Inside Facing South \\
\hline & & 60 & Inside Facing West \\
\hline & & 61 & Outside Facing North \\
\hline & & 62 & Outside Facing East \\
\hline & & 63 & Outside Facing South \\
\hline & & 64 & Outside Facing West \\
\hline
\end{tabular}




\section{Photograph Log, CONTINUED}

\begin{tabular}{|c|c|c|c|}
\hline $\begin{array}{l}\text { CORRECTIVE } \\
\text { ACTION UNIT } \\
\end{array}$ & DATE & $\begin{array}{c}\text { PHOTOGRAPH } \\
\text { NUMBER } \\
\end{array}$ & DESCRIPTION \\
\hline \multirow{32}{*}{110} & \multirow{8}{*}{$12 / 15 / 2009$} & 65 & Inside Facing North \\
\hline & & 66 & Inside Facing East \\
\hline & & 67 & Inside Facing South \\
\hline & & 68 & Inside Facing West \\
\hline & & 69 & Outside Facing North \\
\hline & & 70 & Outside Facing East \\
\hline & & 71 & Outside Facing South \\
\hline & & 72 & Outside Facing West \\
\hline & \multirow{8}{*}{ 03/17/2010 } & 73 & Inside Facing North \\
\hline & & 74 & Inside Facing East \\
\hline & & 75 & Inside Facing South \\
\hline & & 76 & Inside Facing West \\
\hline & & 77 & Outside Facing North \\
\hline & & 78 & Outside Facing East \\
\hline & & 79 & Outside Facing South \\
\hline & & 80 & Outside Facing West \\
\hline & \multirow{8}{*}{ 06/23/2010 } & 81 & Inside Facing North \\
\hline & & 82 & Inside Facing East \\
\hline & & 83 & Inside Facing South \\
\hline & & 84 & Inside Facing West \\
\hline & & 85 & Outside Facing North \\
\hline & & 86 & Outside Facing East \\
\hline & & 87 & Outside Facing South \\
\hline & & 88 & Outside Facing West \\
\hline & \multirow{8}{*}{ 09/08/2010 } & 89 & Inside Facing North \\
\hline & & 90 & Inside Facing East \\
\hline & & 91 & Inside Facing South \\
\hline & & 92 & Inside Facing West \\
\hline & & 93 & Outside Facing North \\
\hline & & 94 & Outside Facing East \\
\hline & & 95 & Outside Facing South \\
\hline & & 96 & Outside Facing West \\
\hline
\end{tabular}


RCRA Post-Closure Report

Revision: 0

Date: January 2011

\section{THIS PAGE INTENTIONALLY LEFT BLANK}




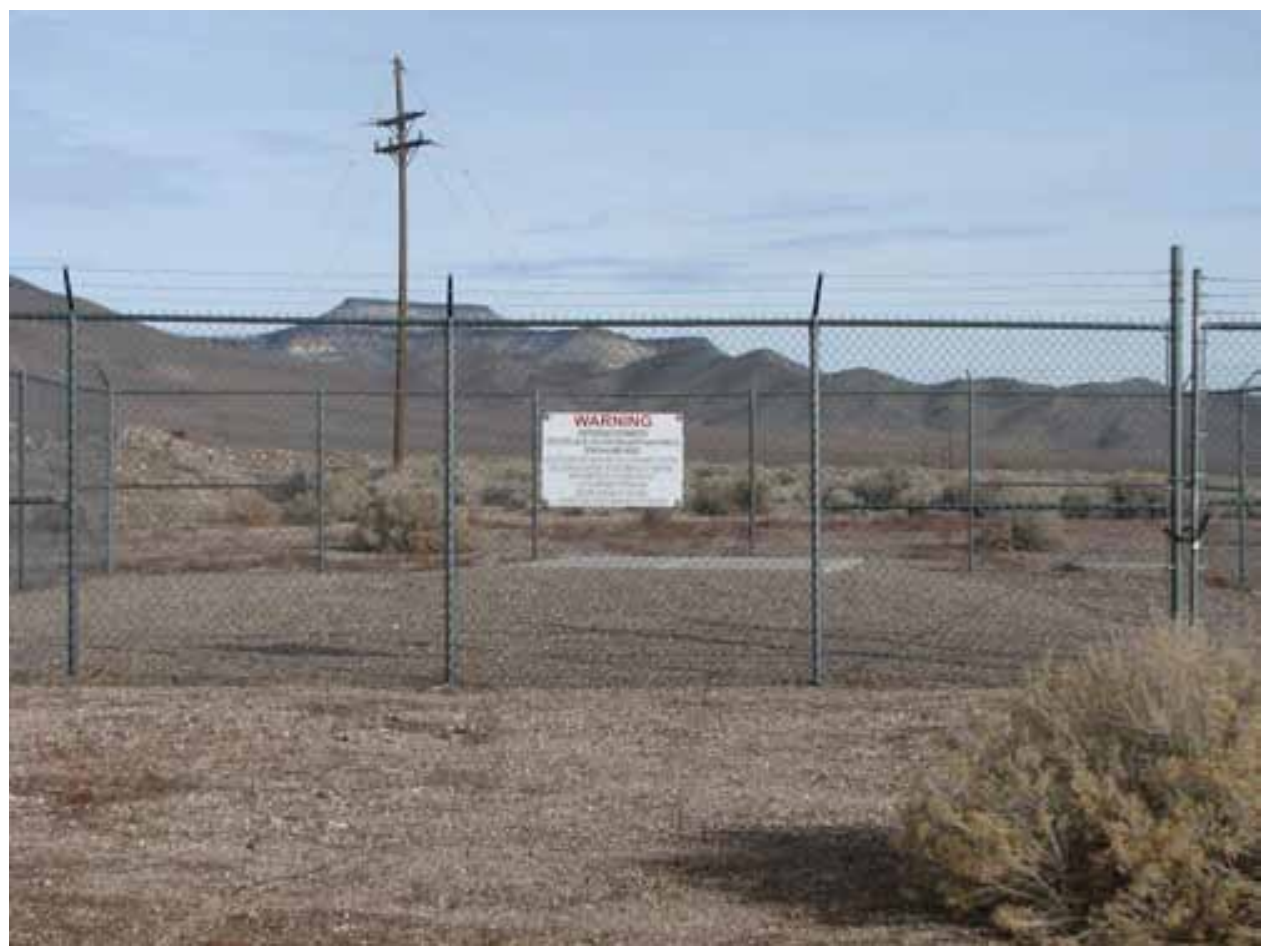

Photograph 1: CAU 90, West Unit Facing North, 12/15/2009

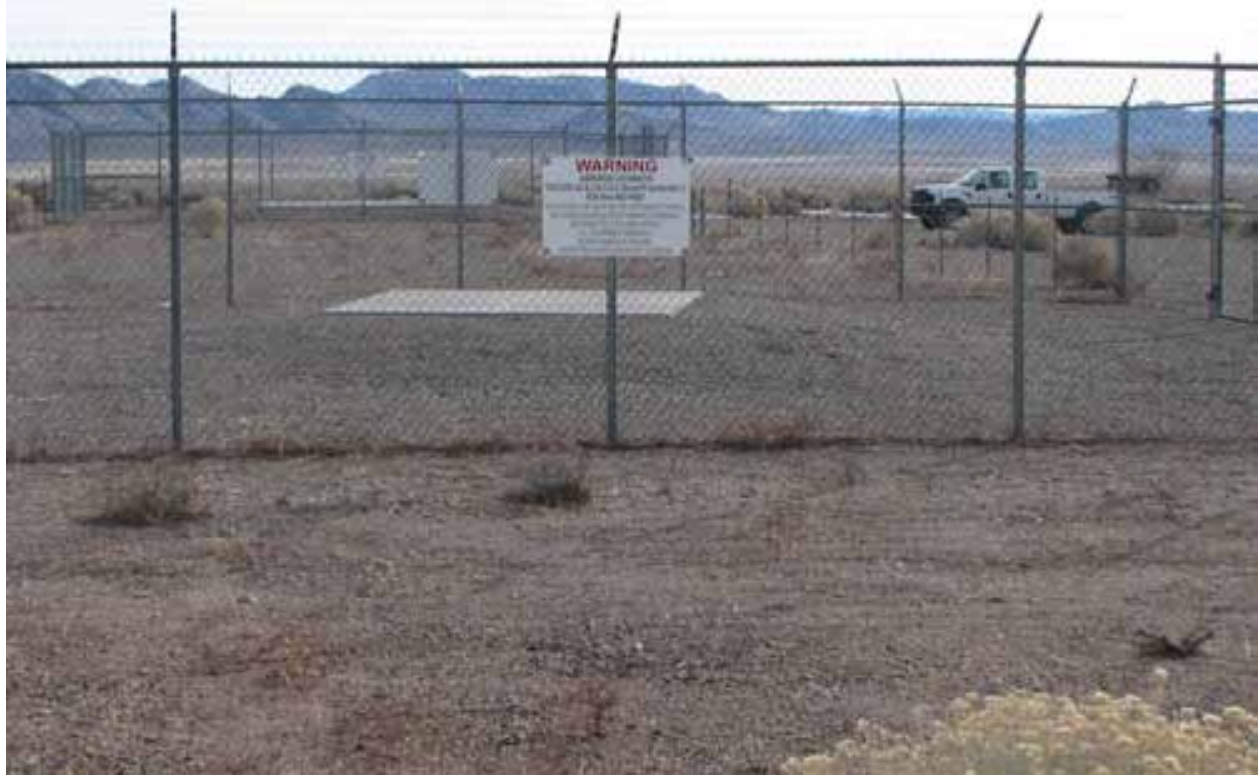

Photograph 2: CAU 90, West Unit Facing East, 12/15/2009 


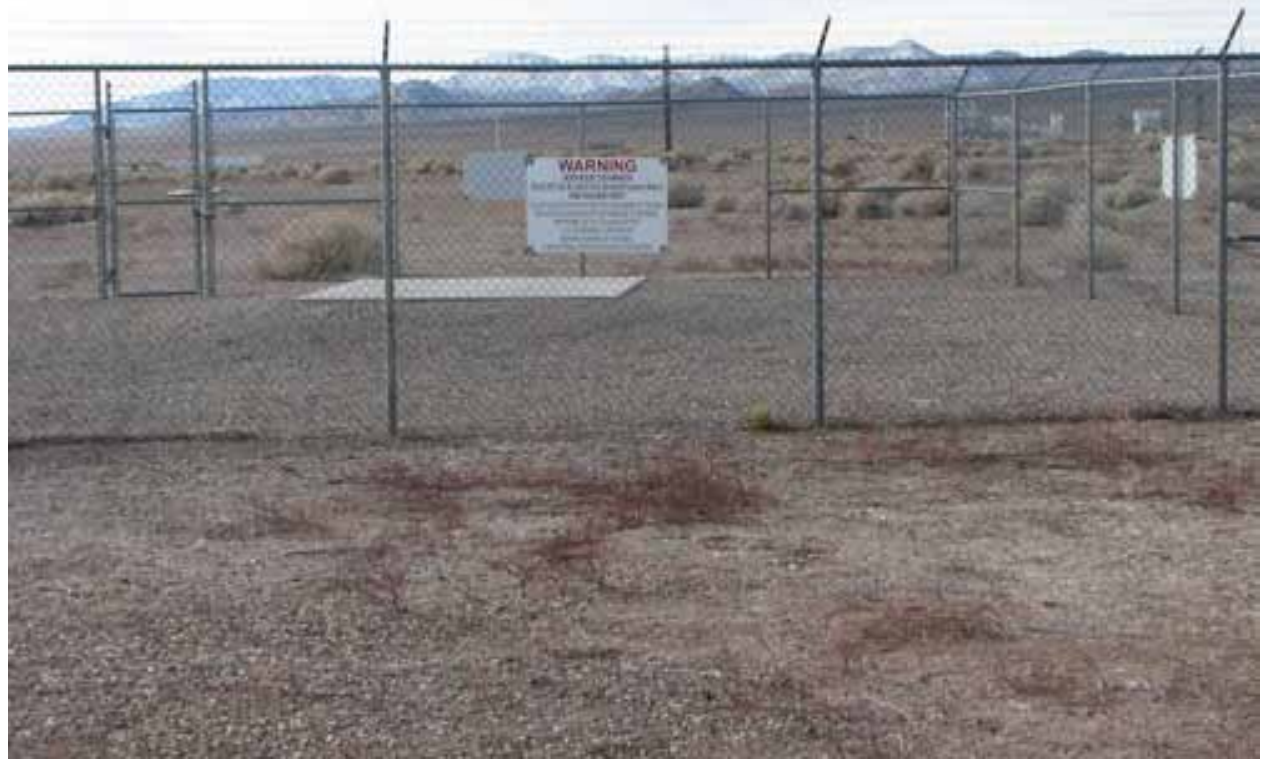

Photograph 3: CAU 90, West Unit Facing South, 12/15/2009

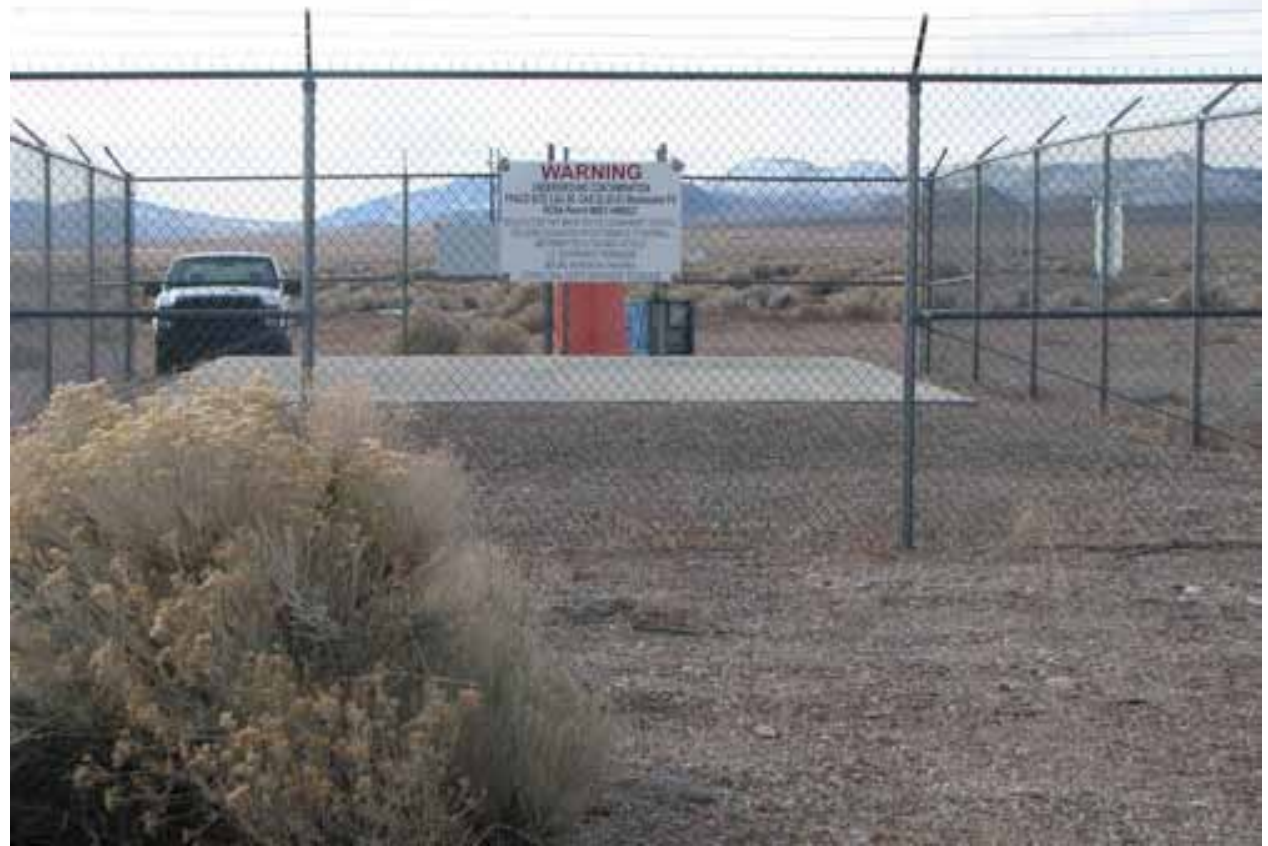

Photograph 4: CAU 90, East Unit Facing South, 12/15/2009 


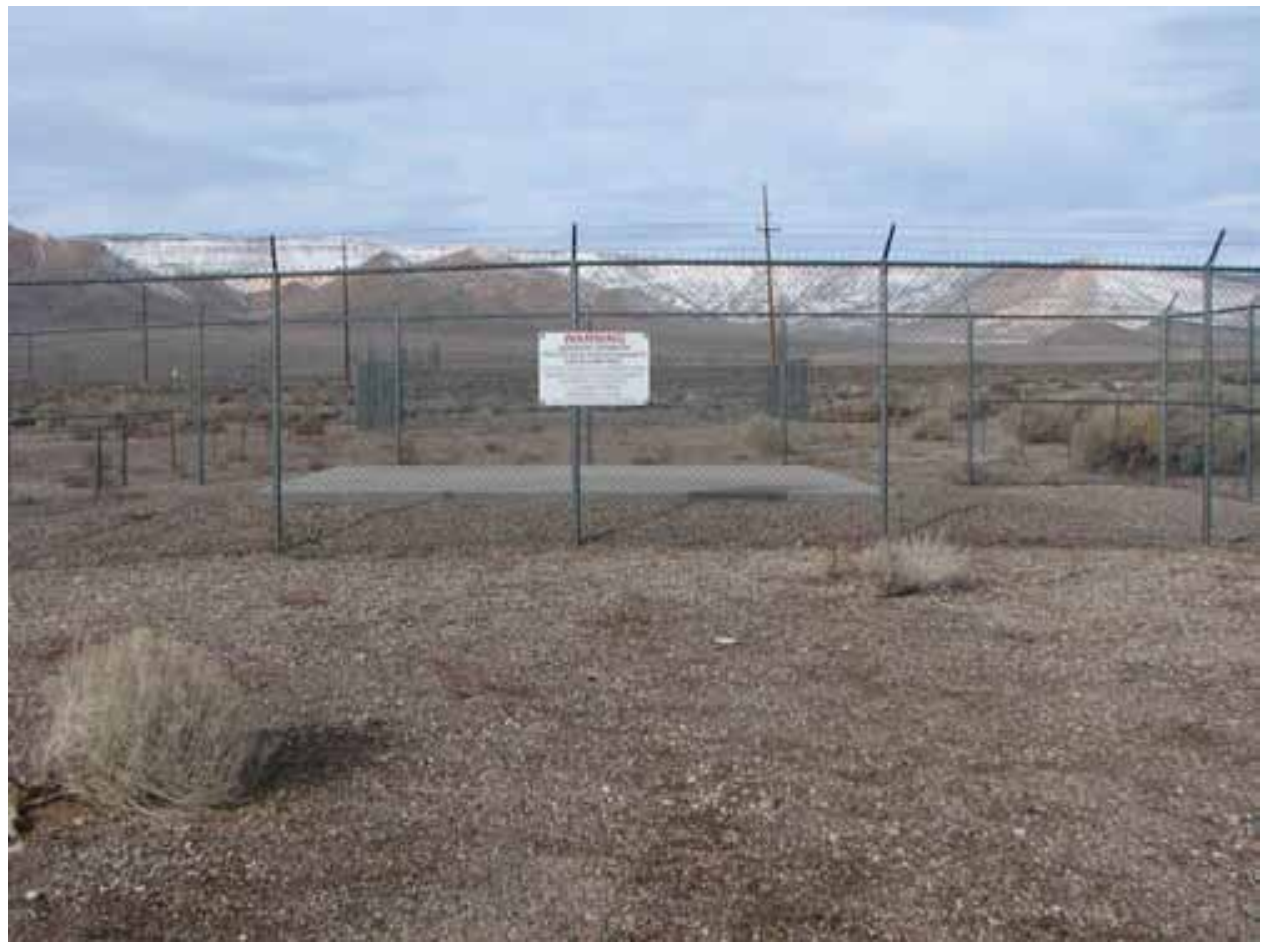

Photograph 5: CAU 90, East Unit Facing West, 12/15/2009

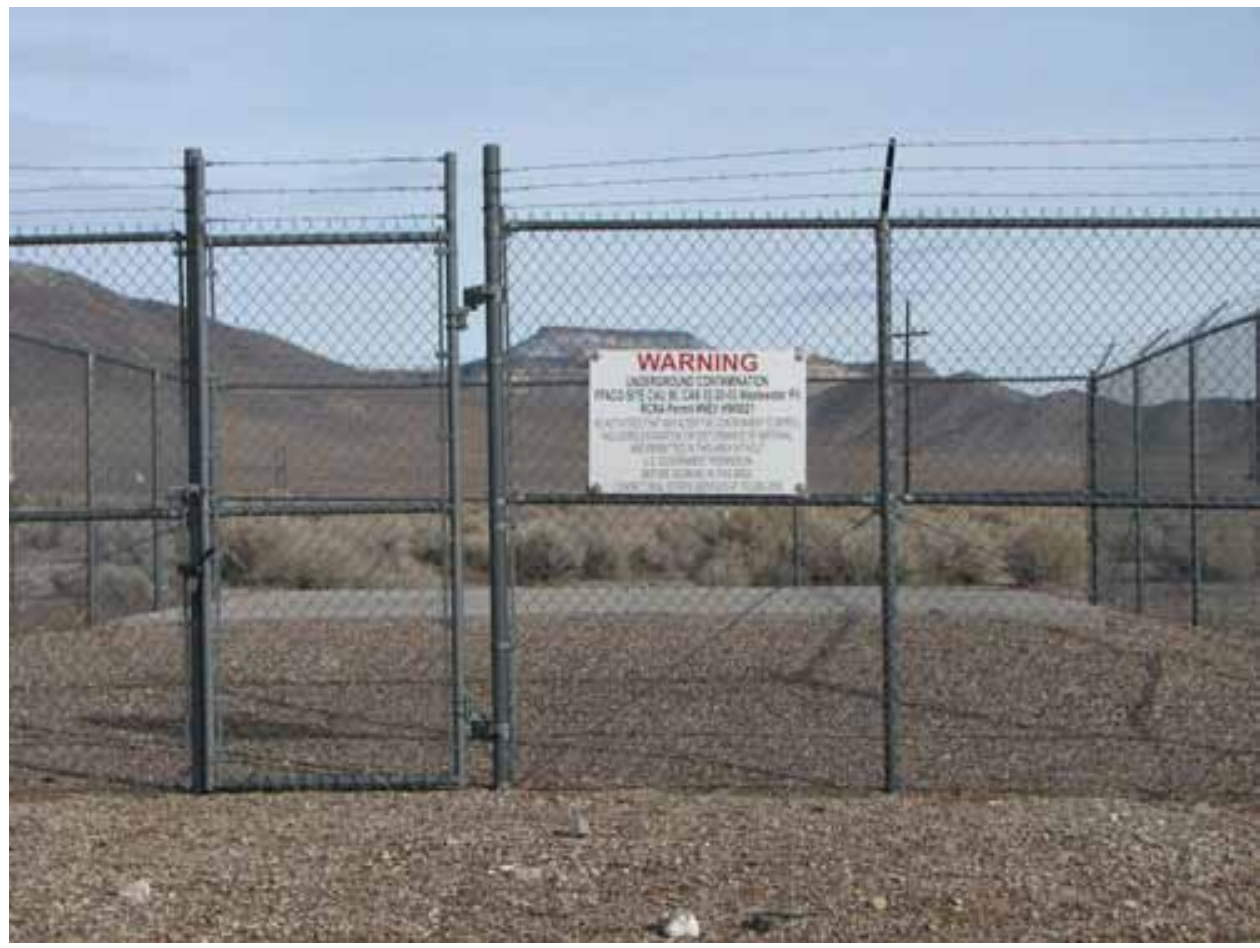

Photograph 6: CAU 90, East Unit Facing North, 12/15/2009 


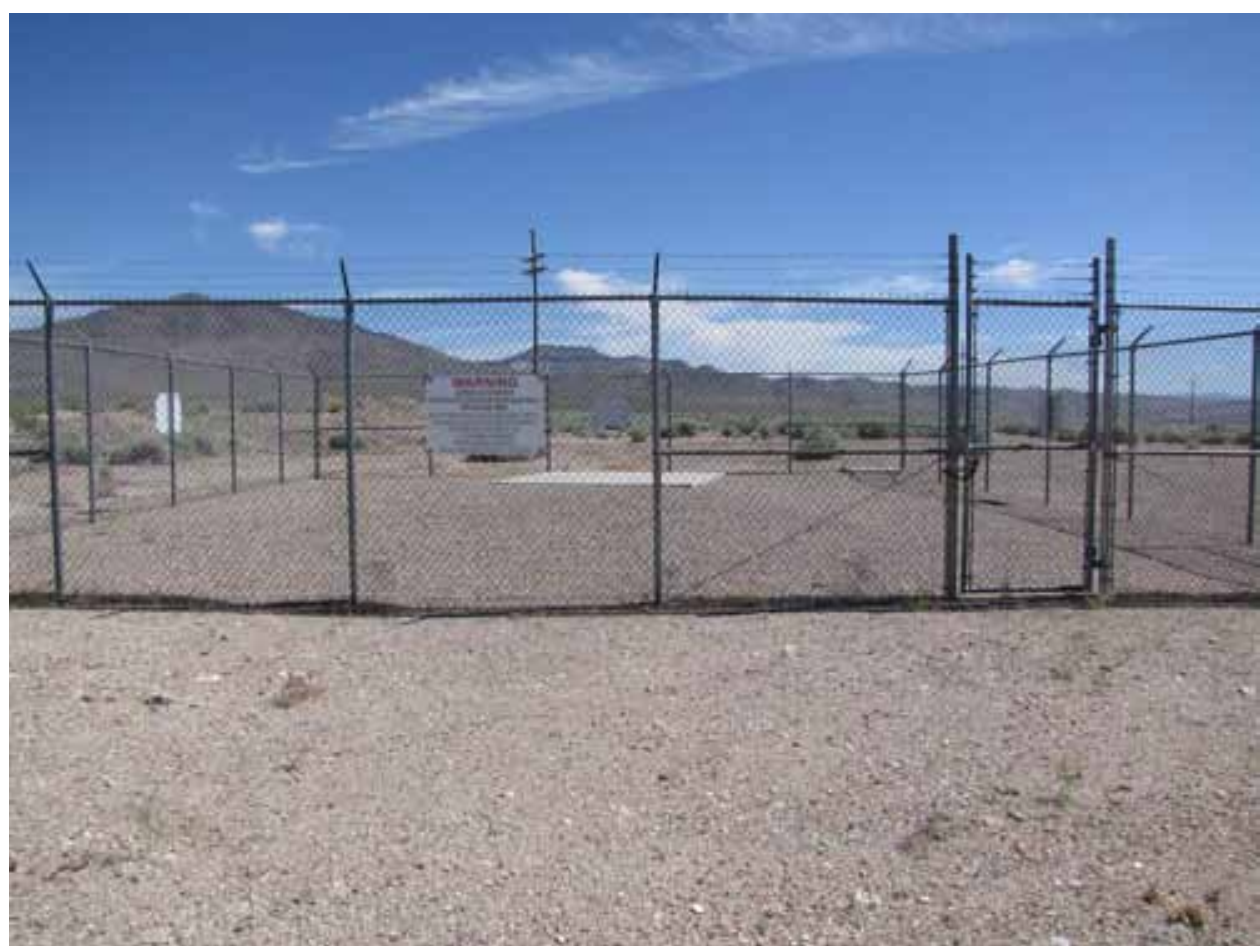

Photograph 7: CAU 90, West Unit Facing North, 06/23/2010

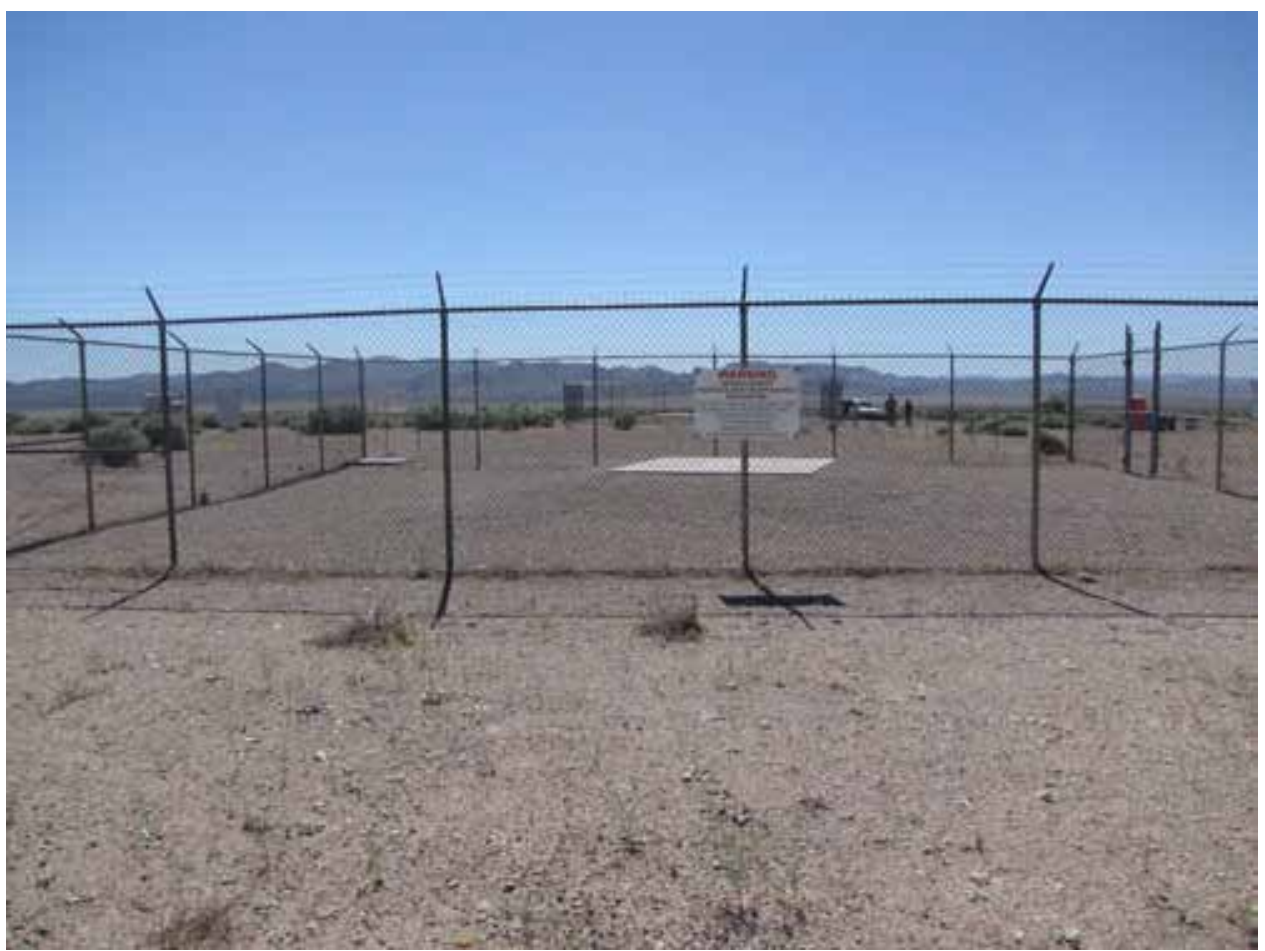

Photograph 8: CAU 90, West Unit Facing East, 06/23/2010 


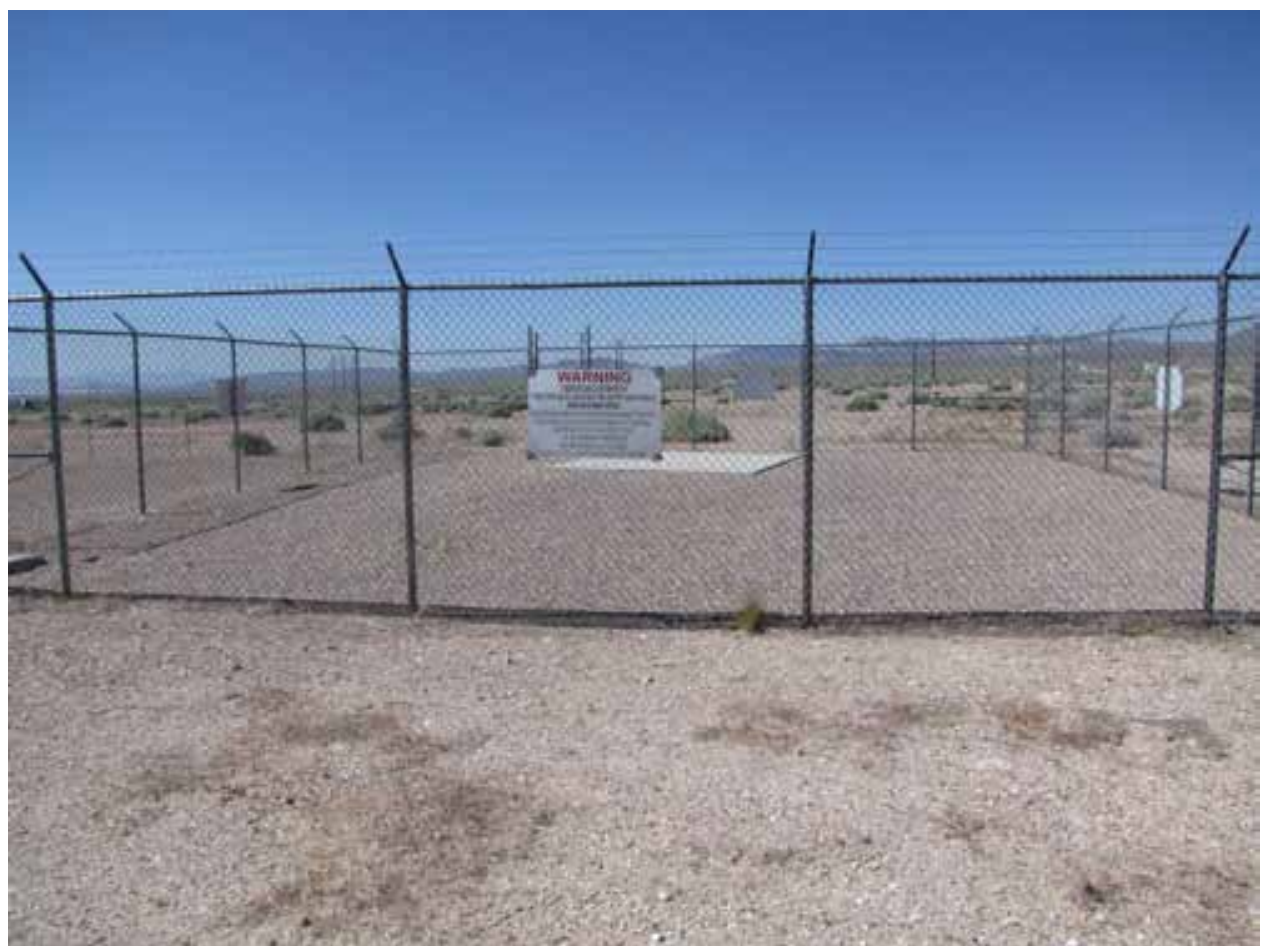

Photograph 9: CAU 90, West Unit Facing South, 06/23/2010

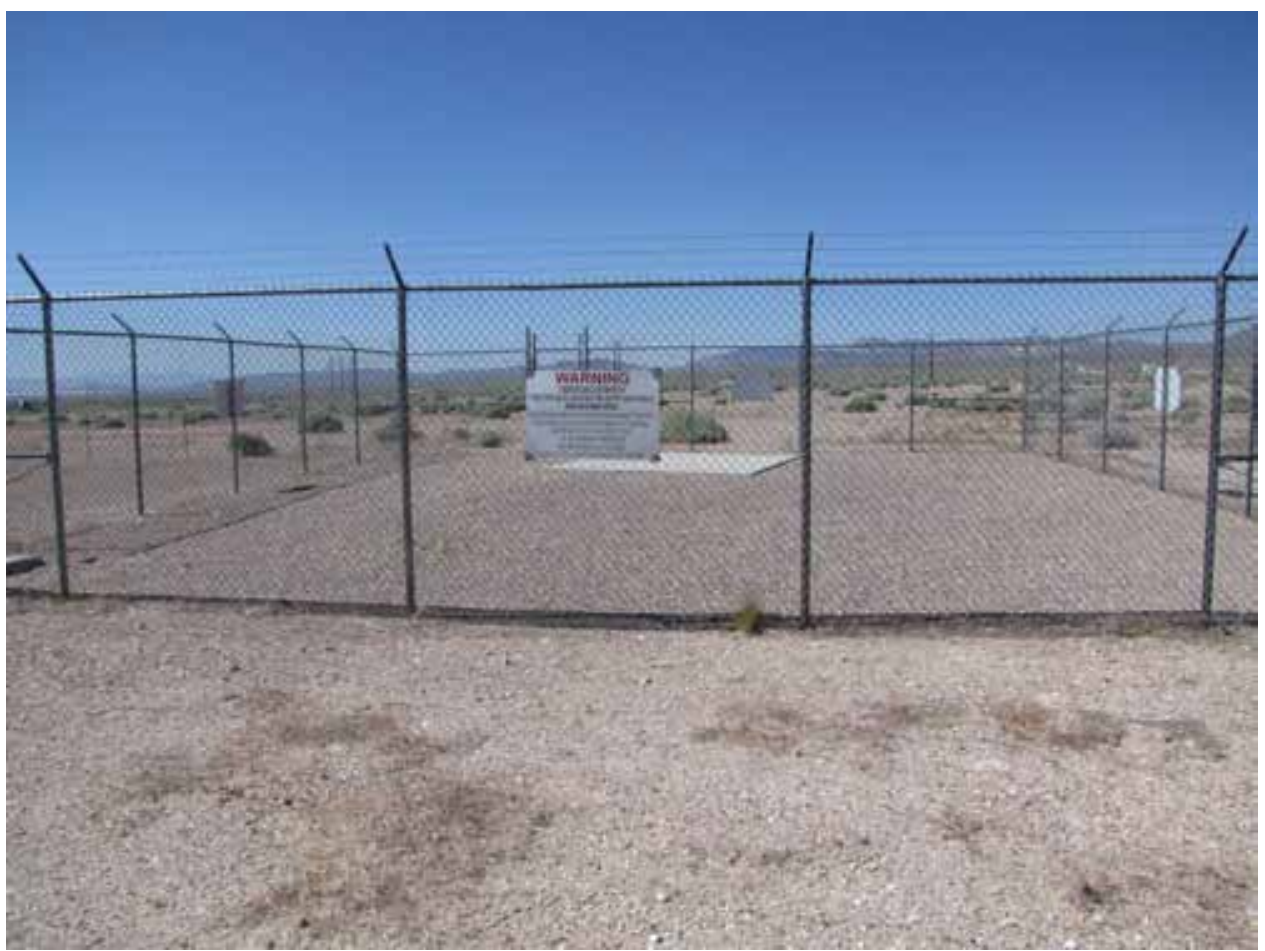

Photograph 10: CAU 90, East Unit Facing South, 06/23/2010 


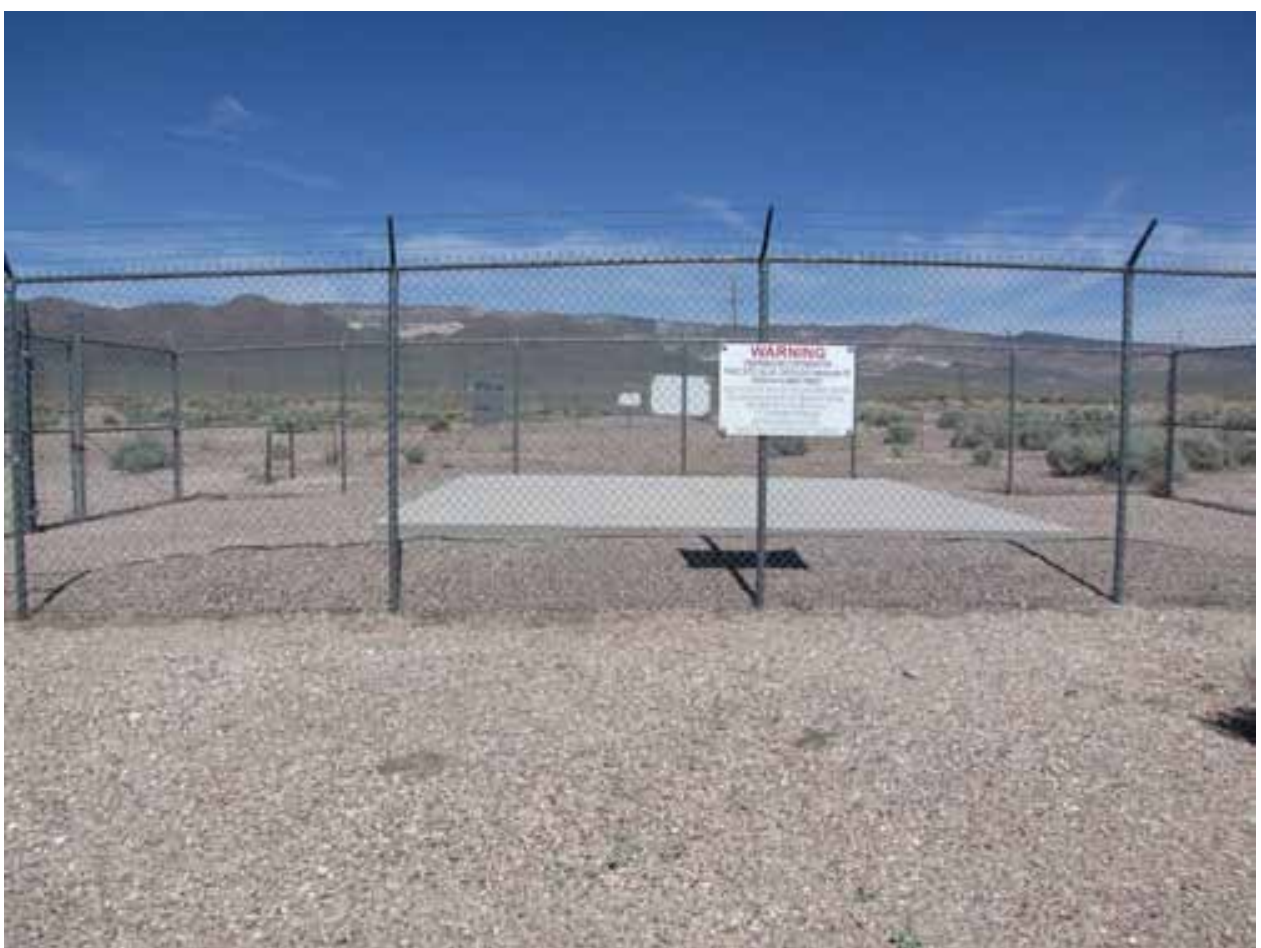

Photograph 11: CAU 90, East Unit Facing West, 06/23/2010

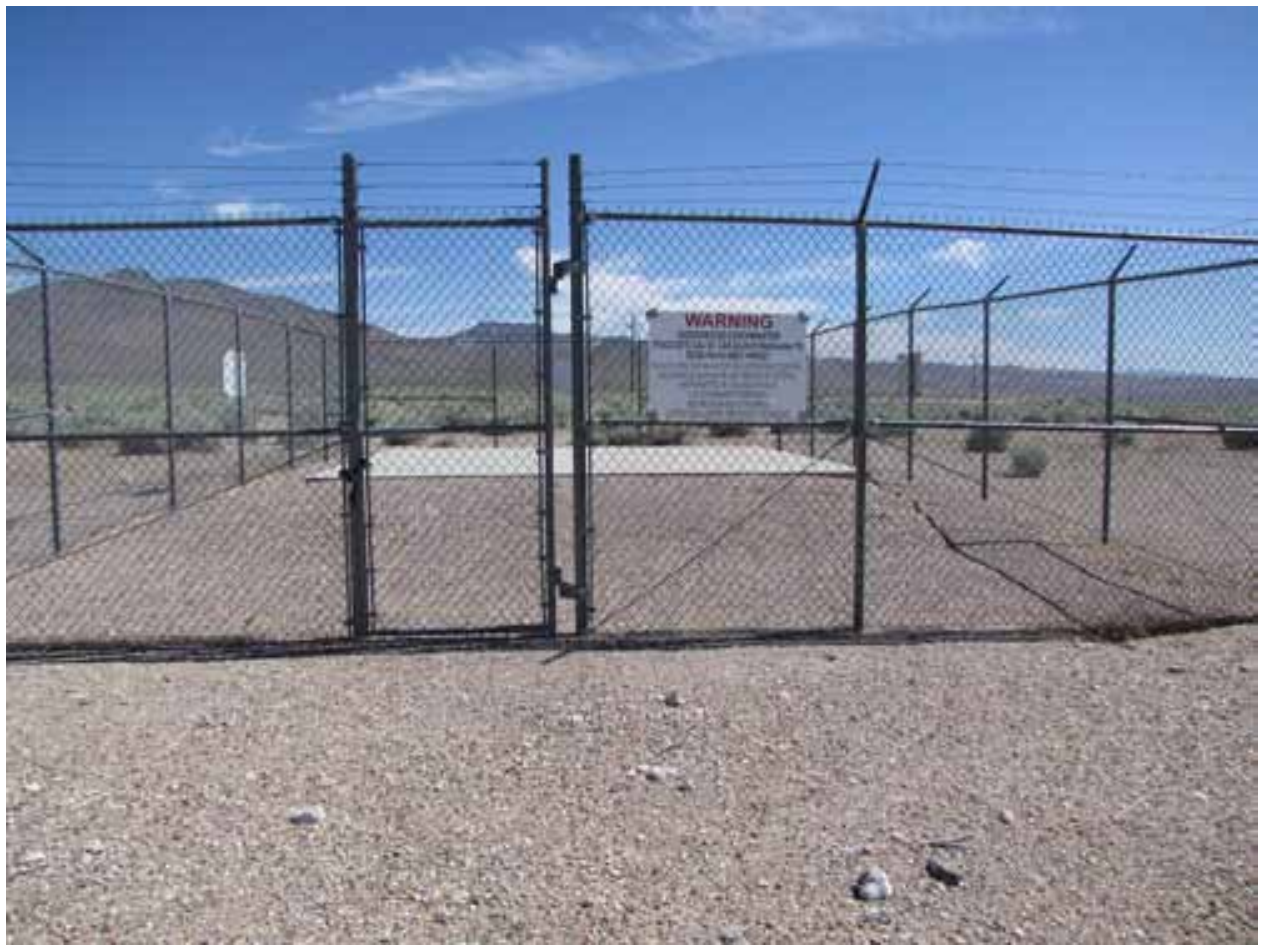

Photograph 12: CAU 90, East Unit Facing North, 06/23/2010 


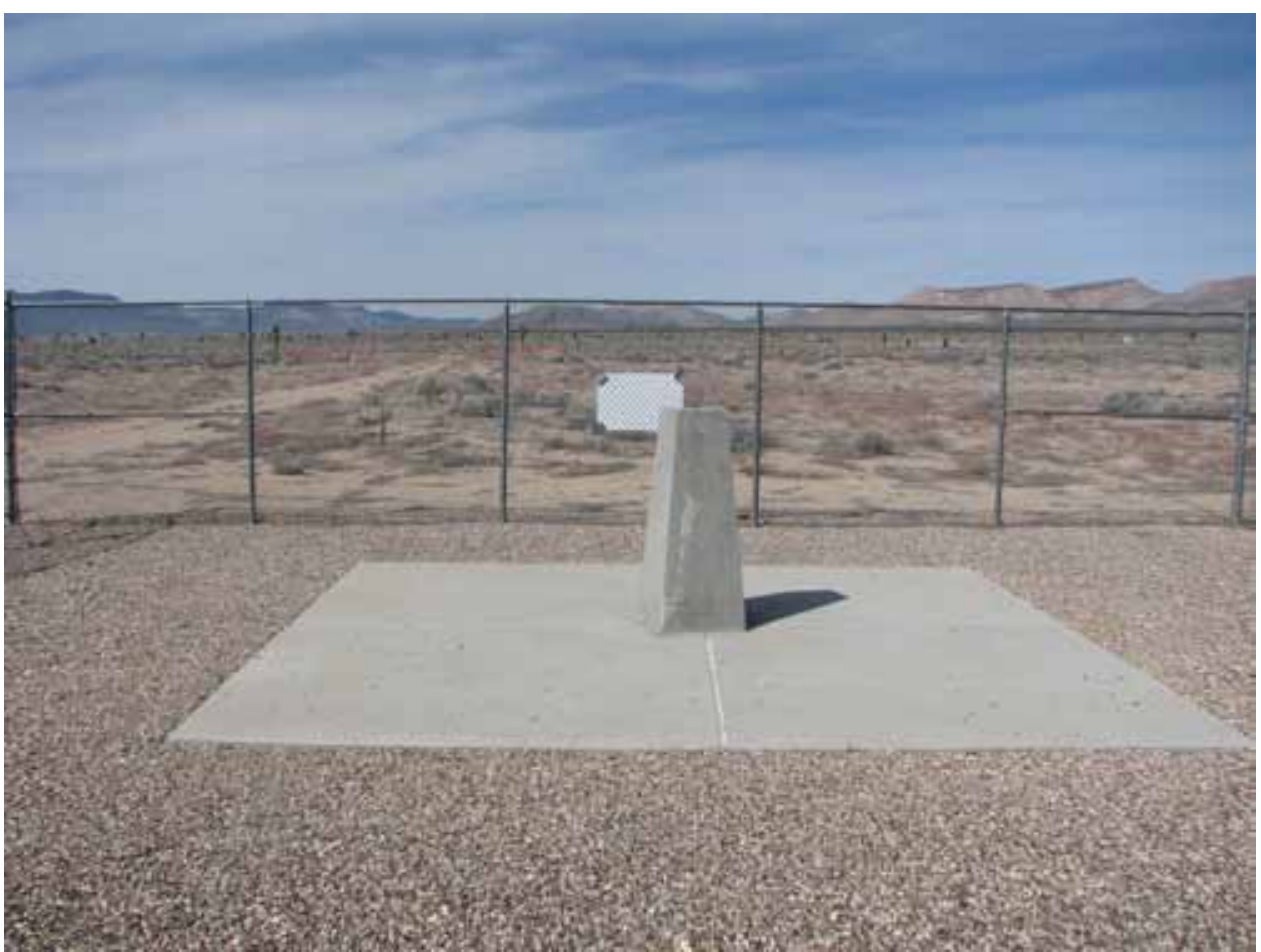

Photograph 13: CAU 91, Inside Facing North, 03/17/2010

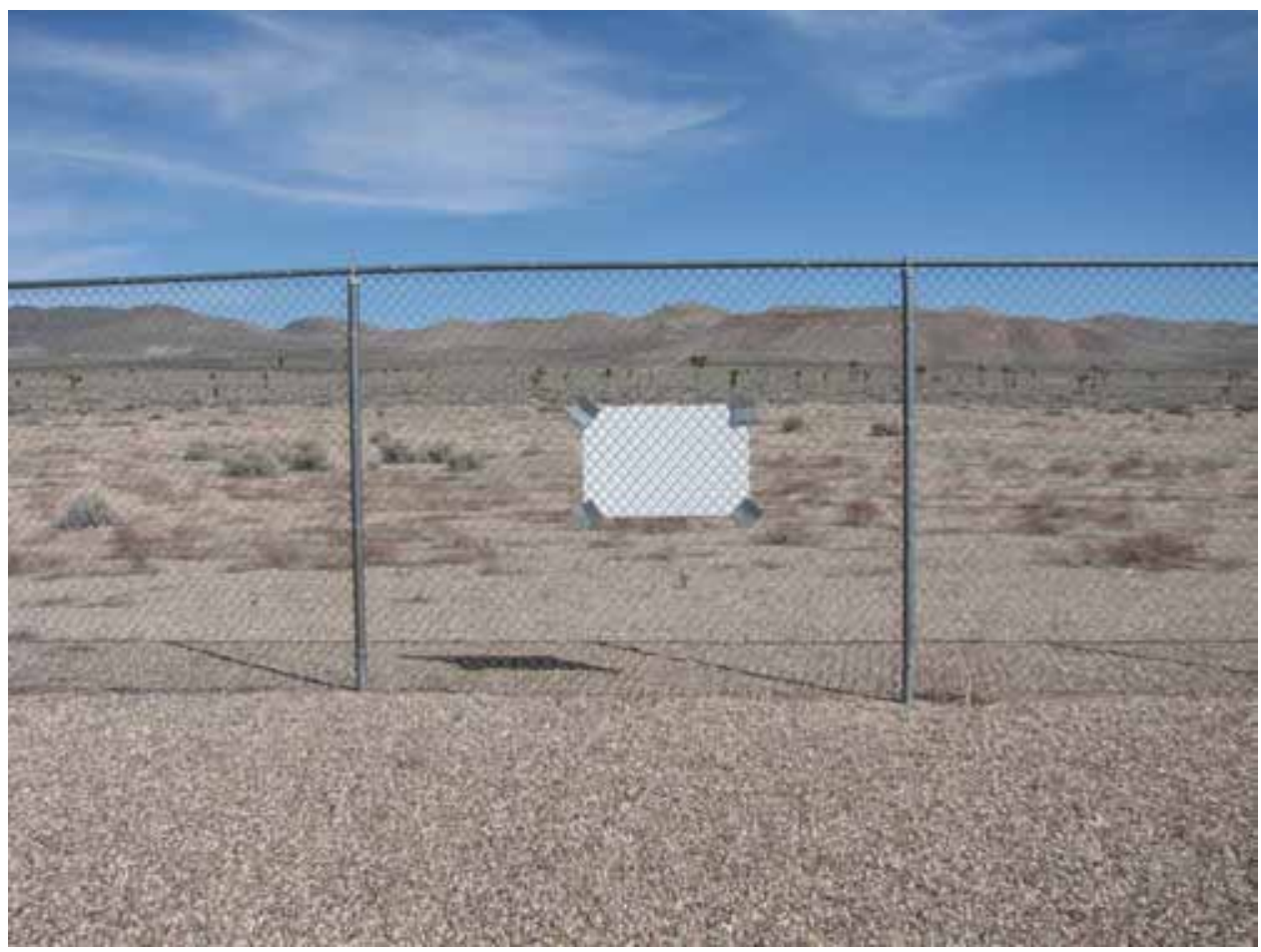

Photograph 14: CAU 91, Inside Facing East, 03/17/2010 
RCRA Post-Closure Report

Revision: 0

Date: January 2011

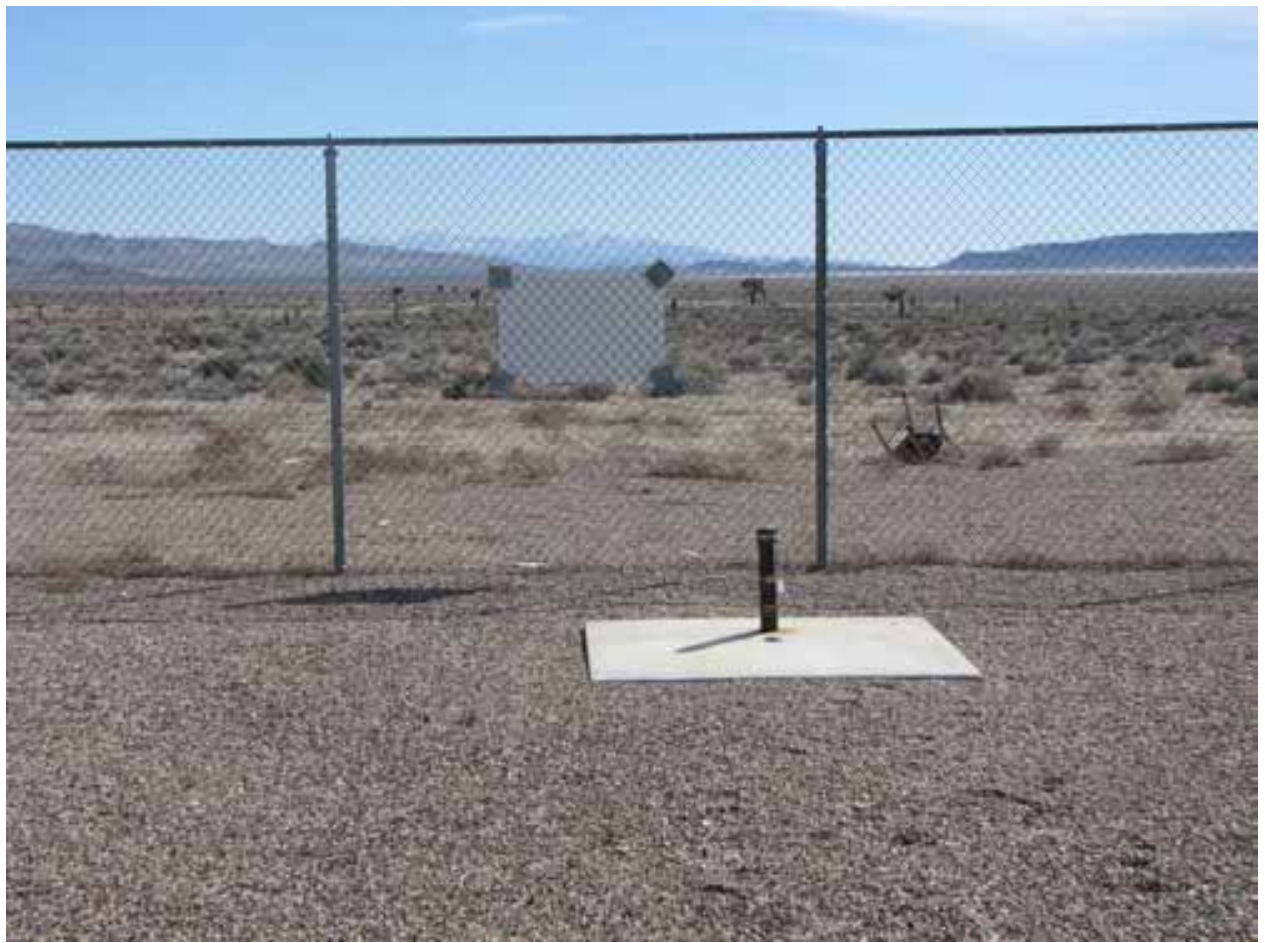

Photograph 15: CAU 91, Inside Facing South, 03/17/2010

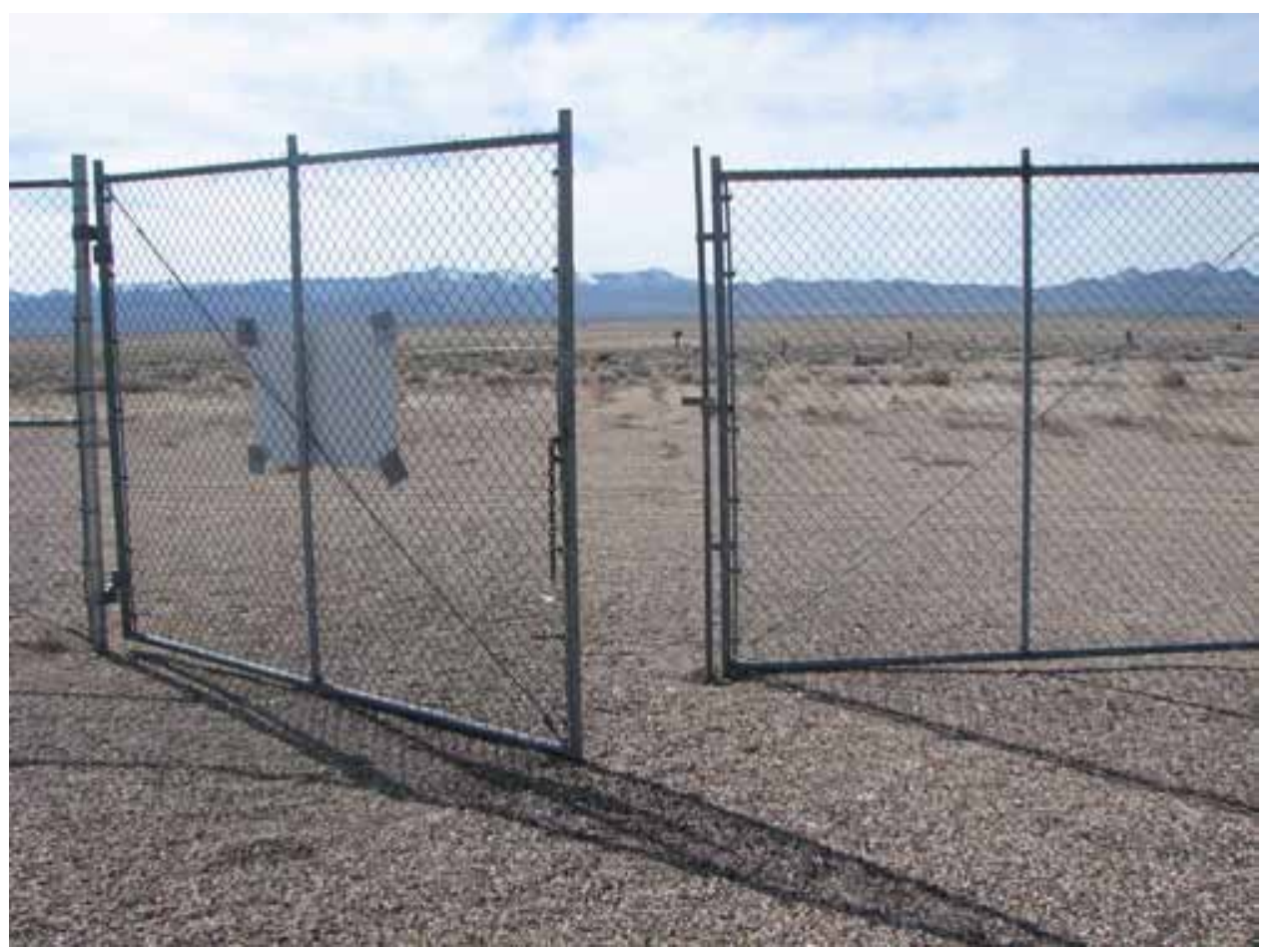

Photograph 16: CAU 91, Inside Facing West, 03/17/2010 


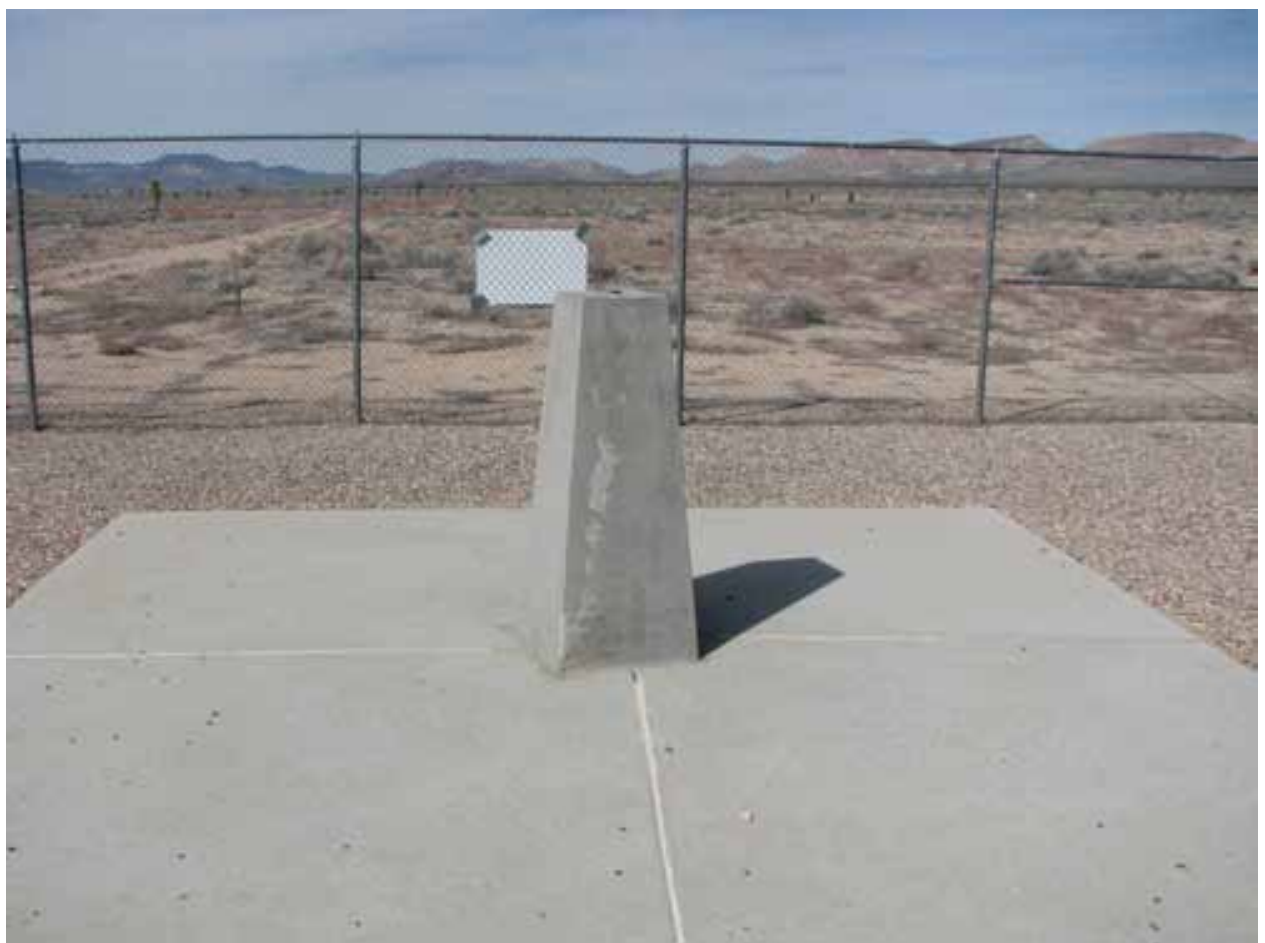

Photograph 17: CAU 91, Surface Monument Facing North, 03/17/2010

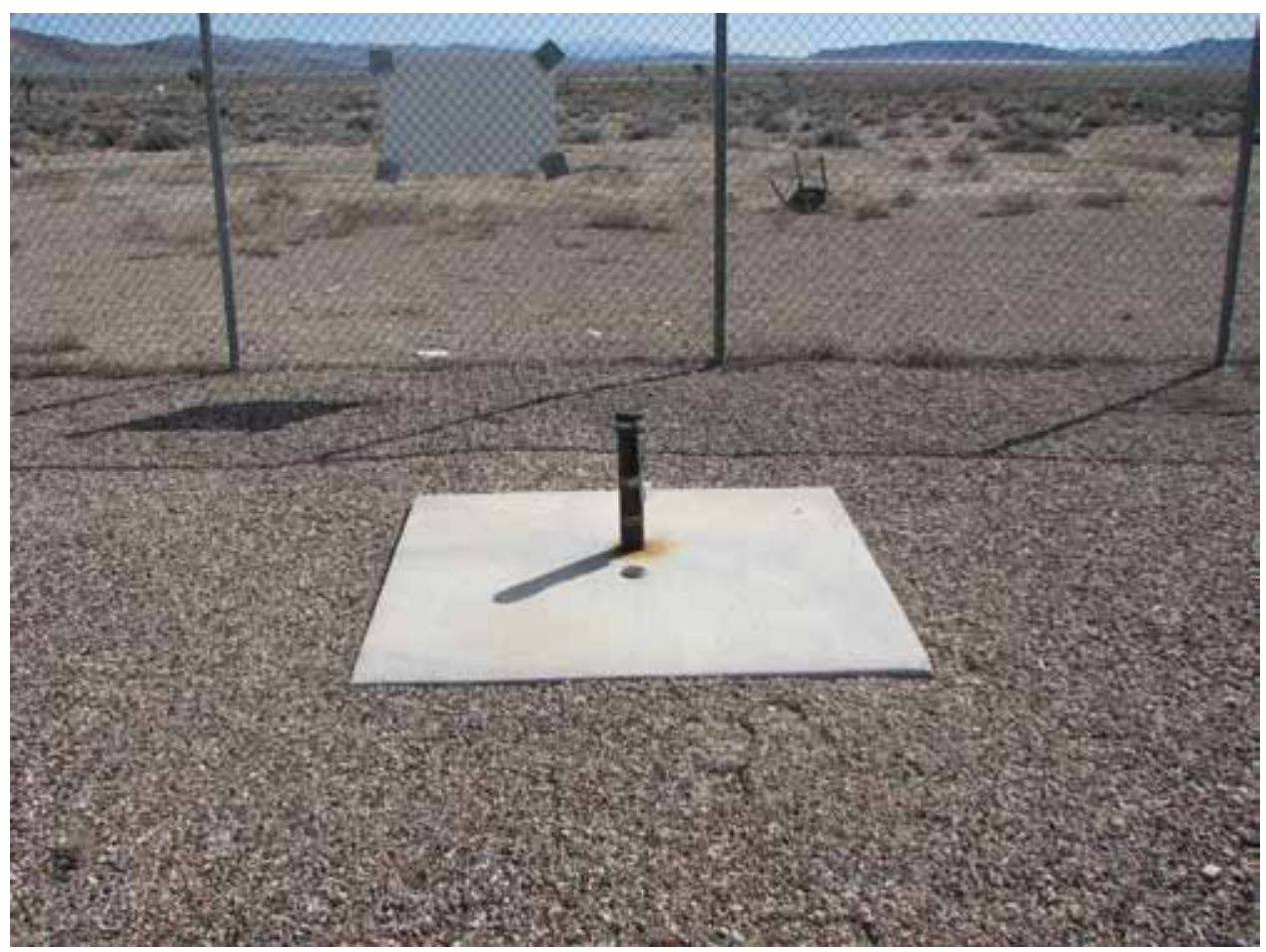

Photograph 18: CAU 91, Surface Monitoring Well Facing South, 03/17/2010 
RCRA Post-Closure Report

Revision: 0

Date: January 2011

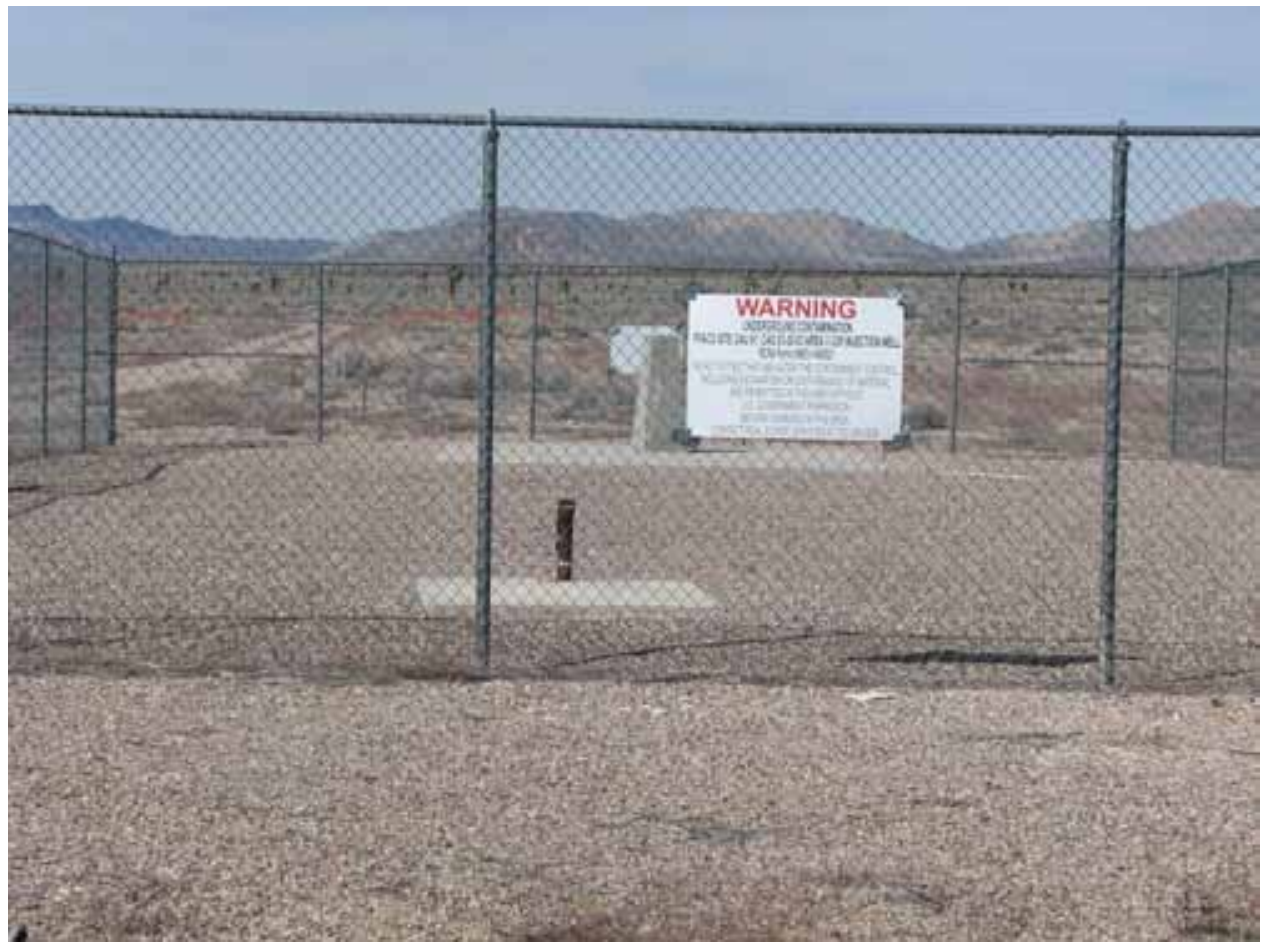

Photograph 19: CAU 91, Outside Facing North, 03/17/2010

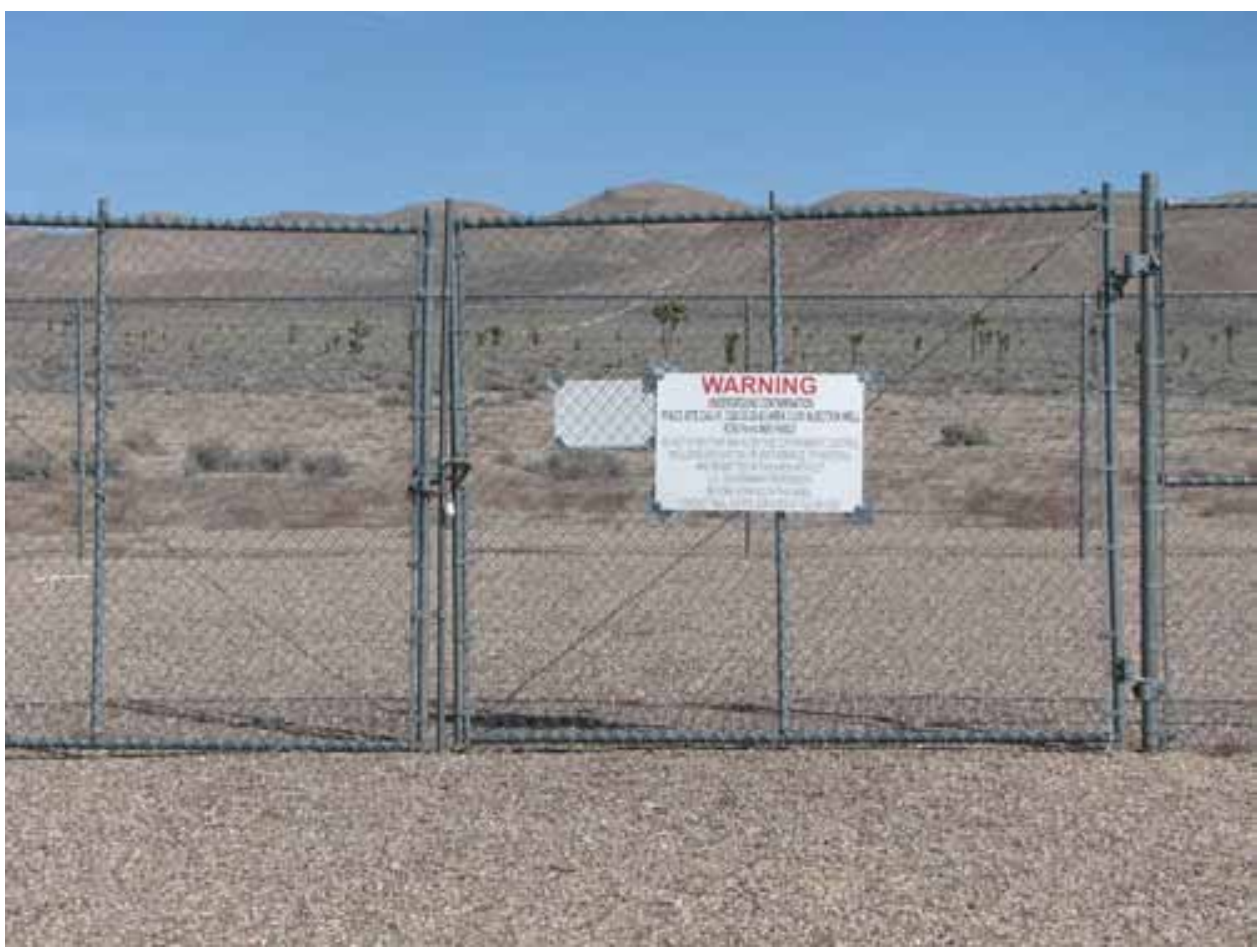

Photograph 20: CAU 91, Outside Facing East, 03/17/2010 


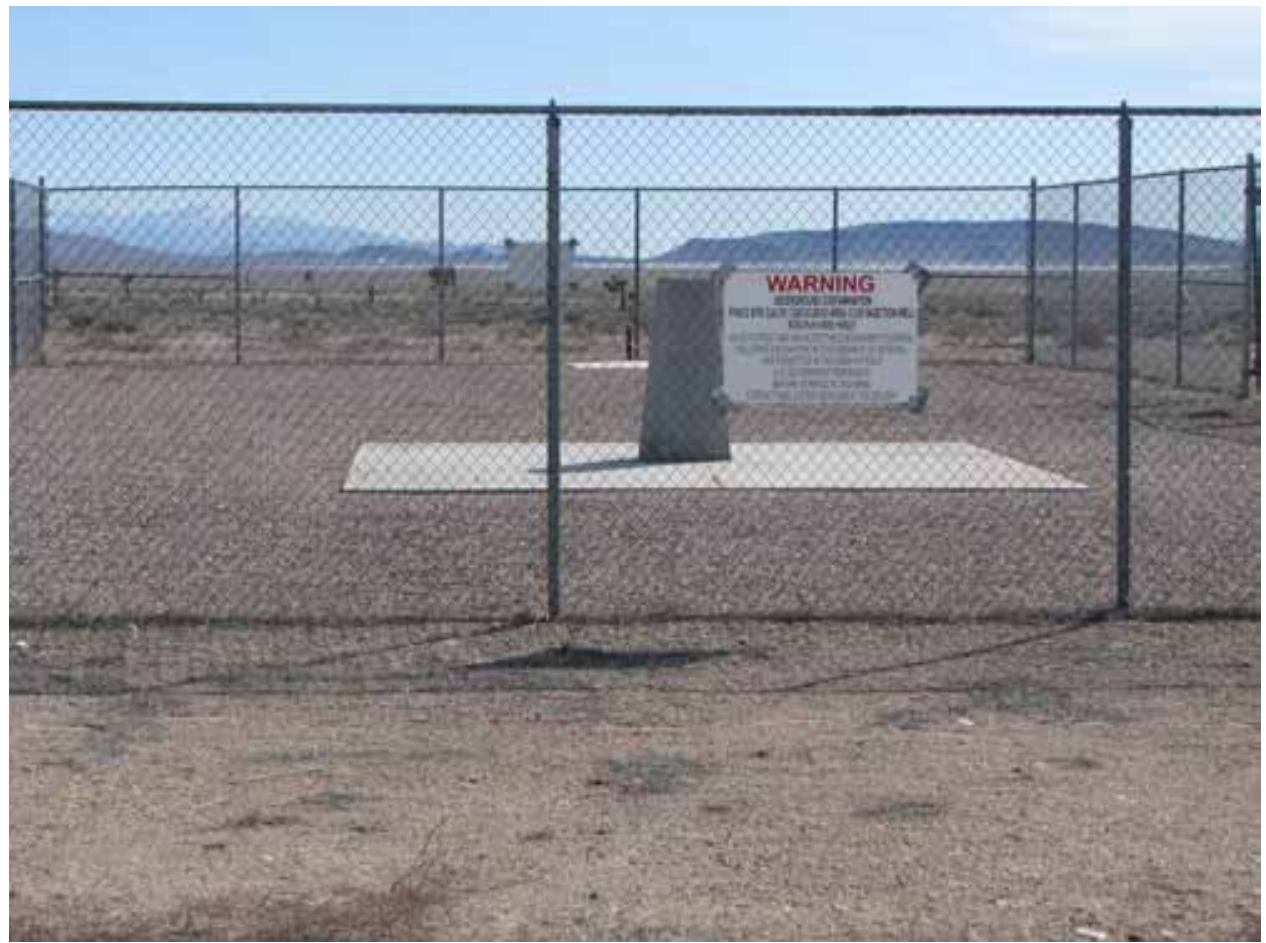

Photograph 21: CAU 91, Outside Facing South, 03/17/2010

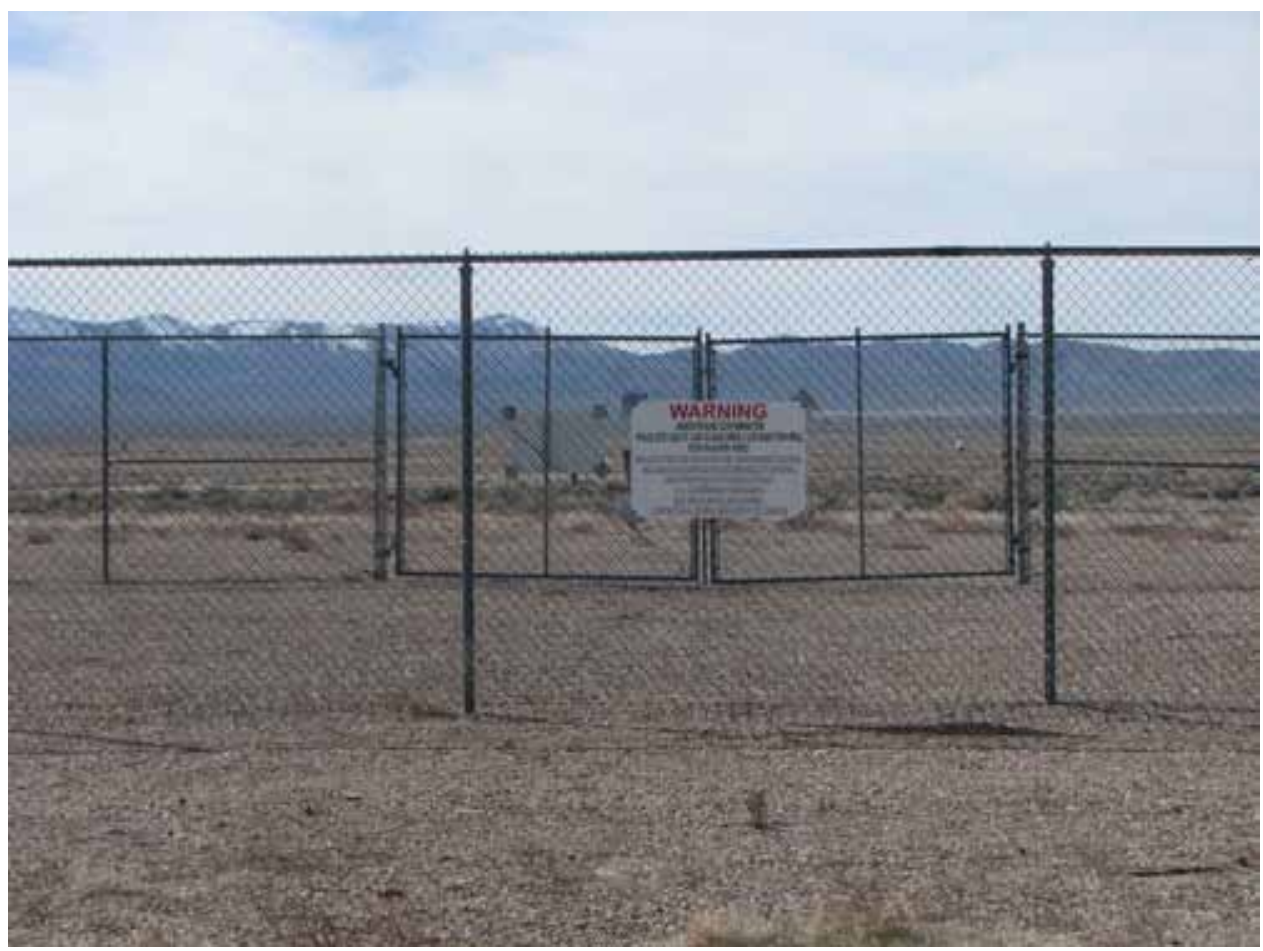

Photograph 22: CAU 91, Outside Facing West, 03/17/2010 


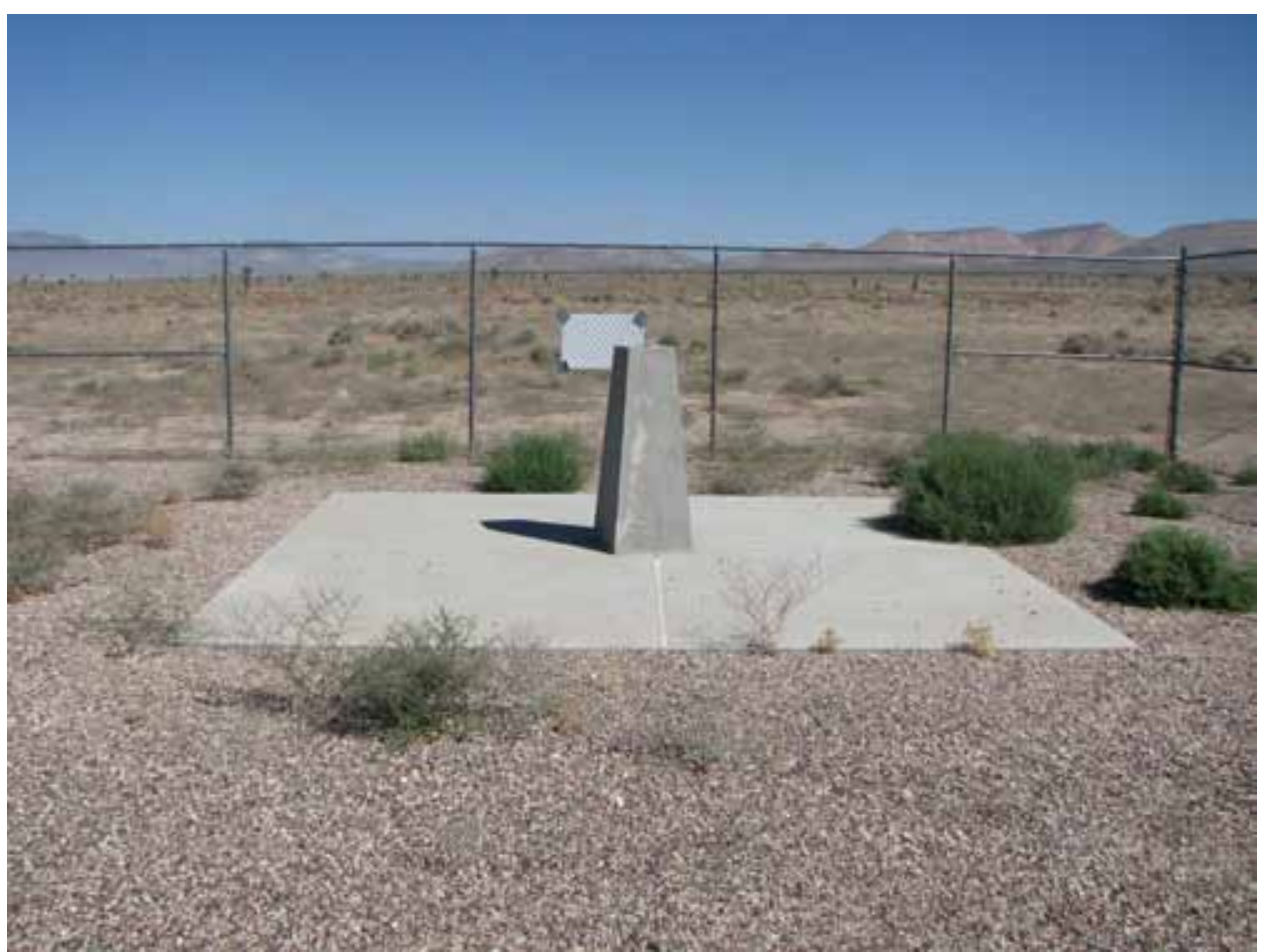

Photograph 23: CAU 91, Inside Facing North, 09/08/2010

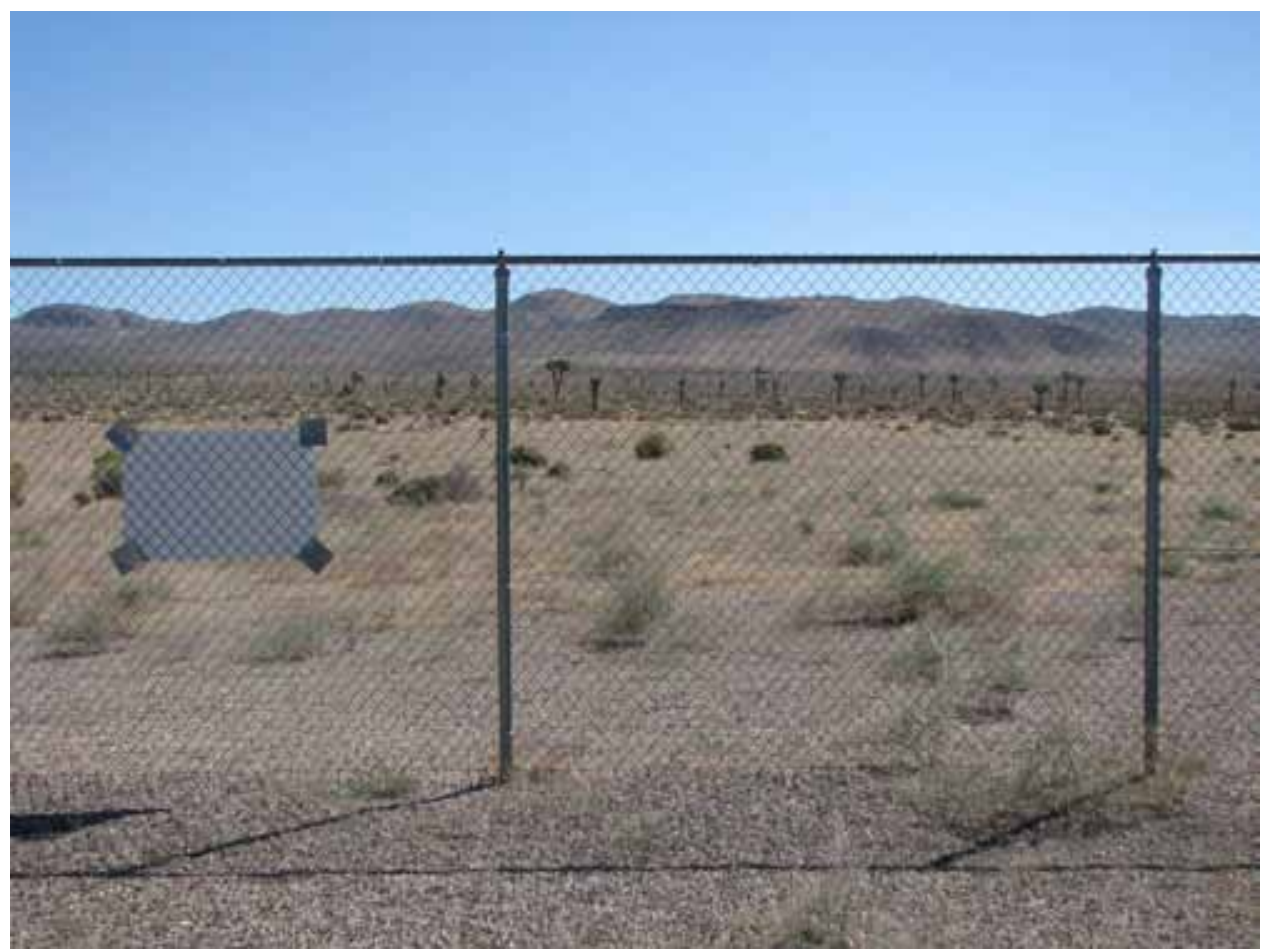

Photograph 24: CAU 91, Inside Facing East, 09/08/2010 


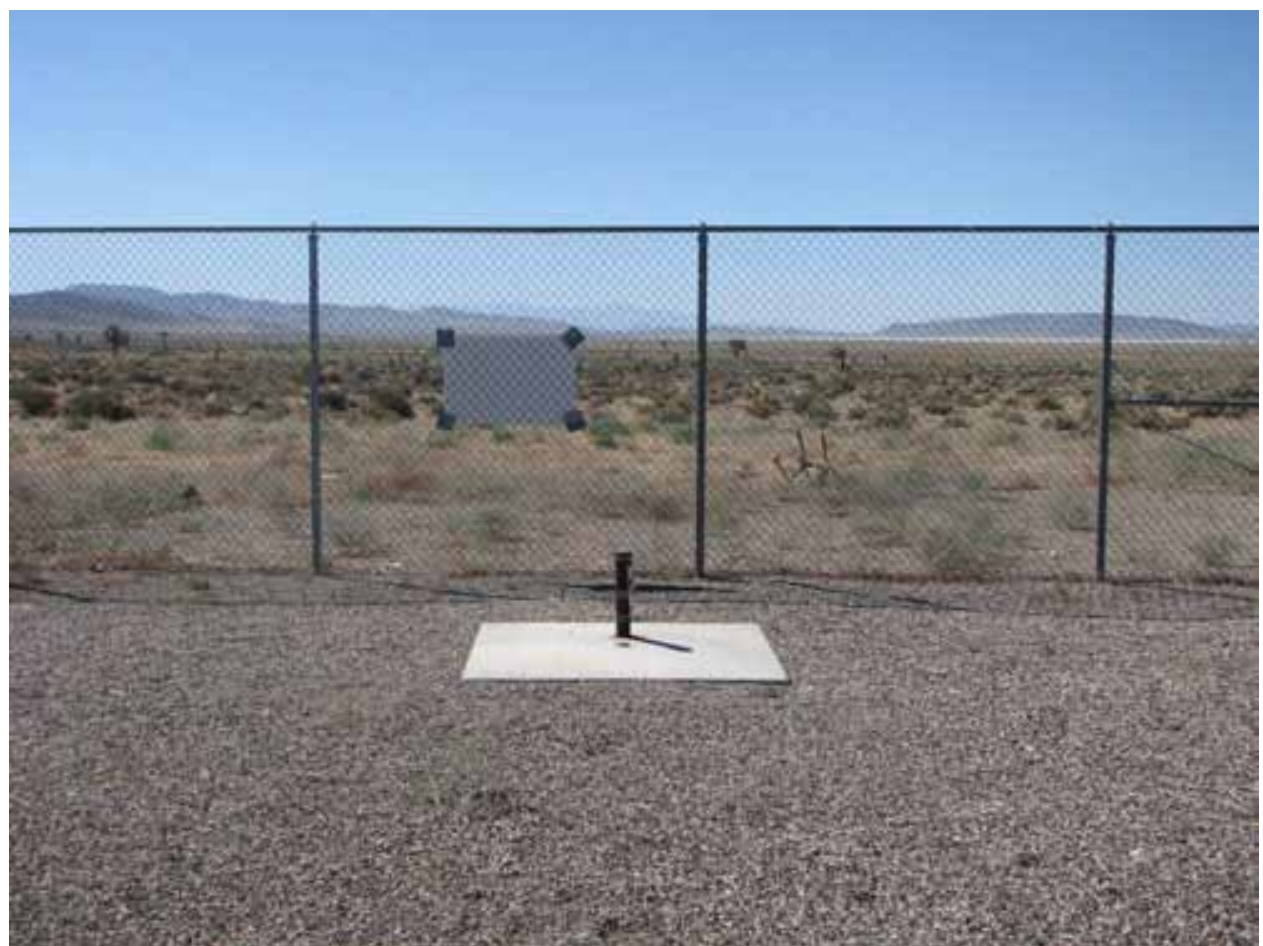

Photograph 25: CAU 91, Inside Facing South, 09/08/2010

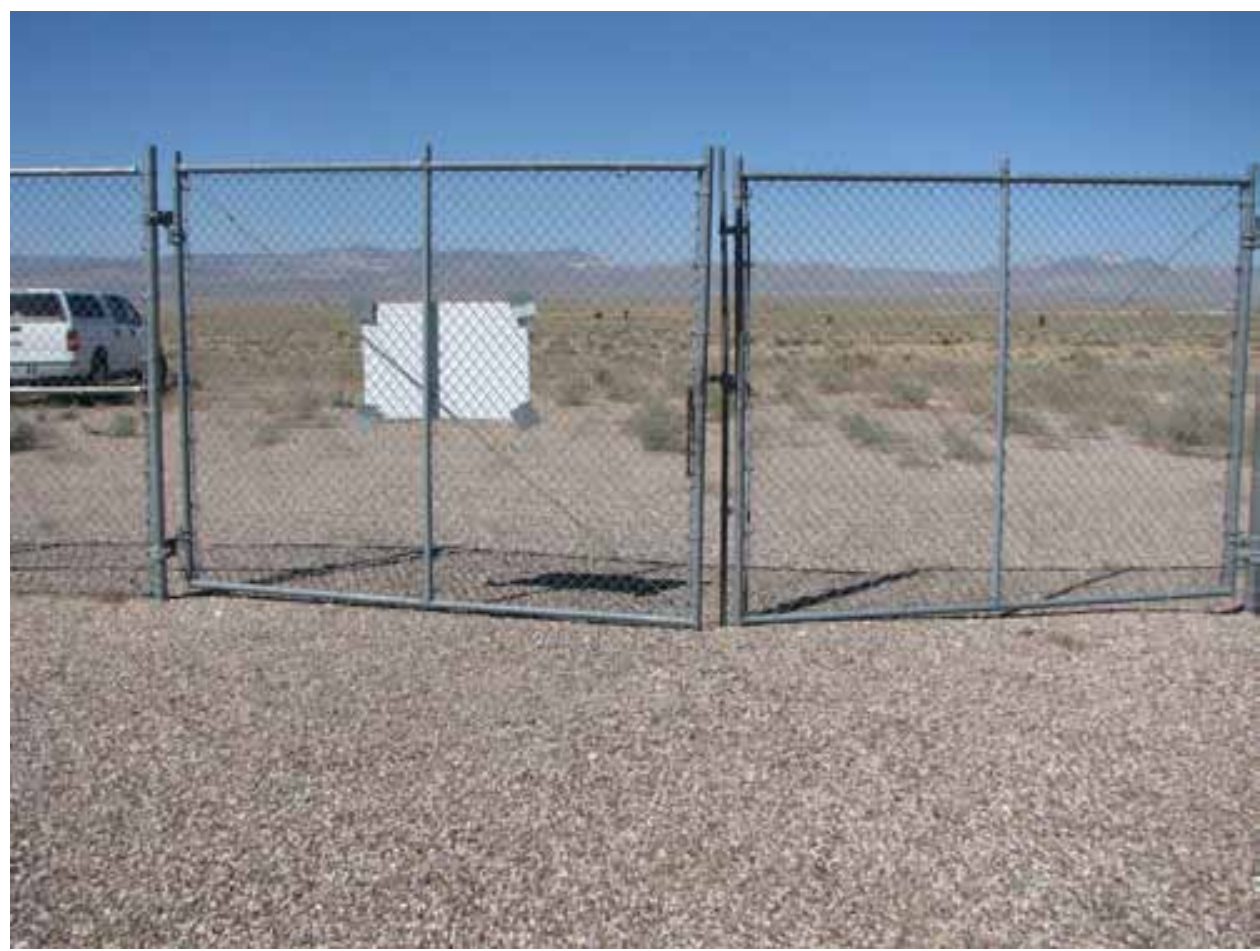

Photograph 26: CAU 91, Inside Facing West, 09/08/2010 


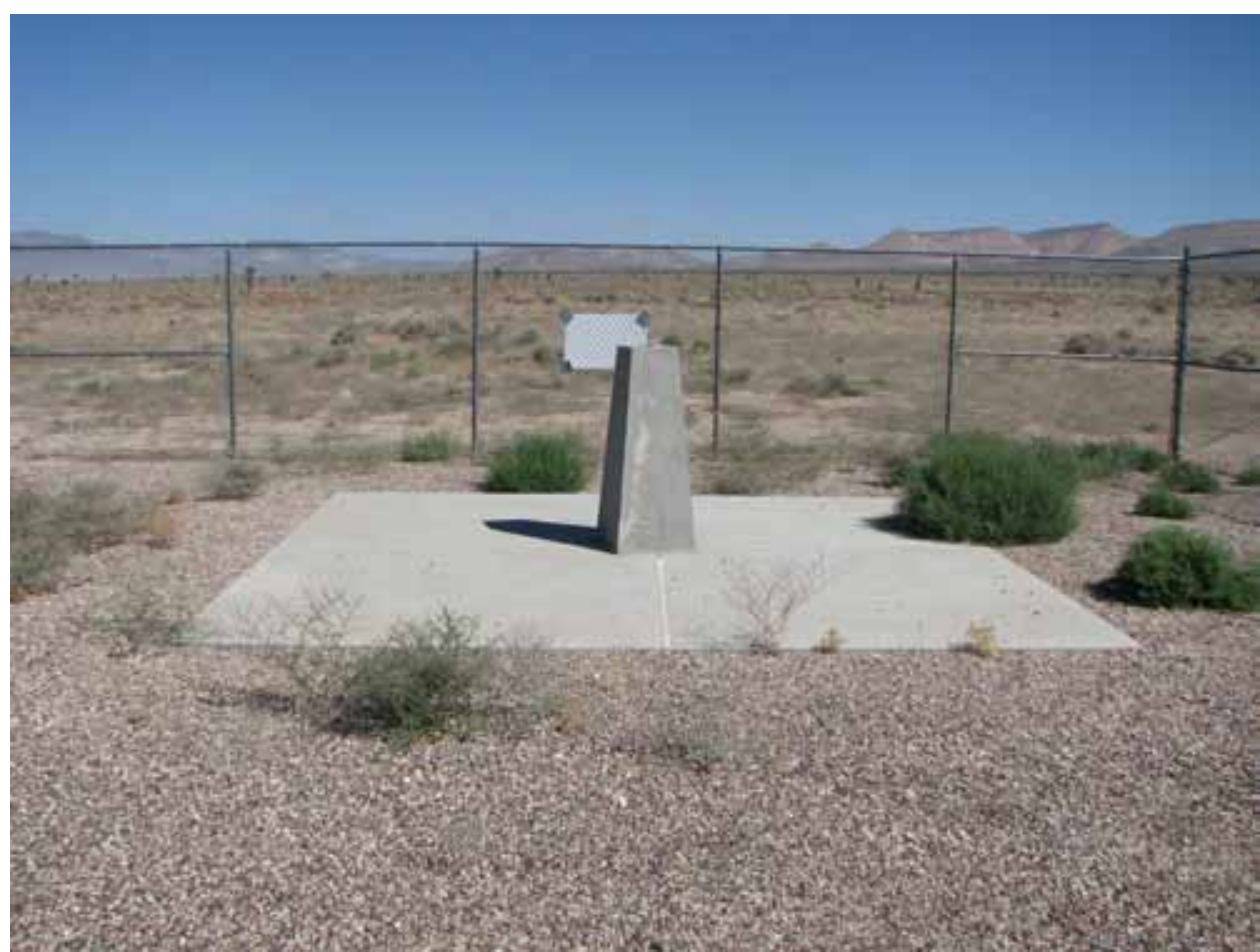

Photograph 27: CAU 91, Surface Monument Facing North, 09/08/2010

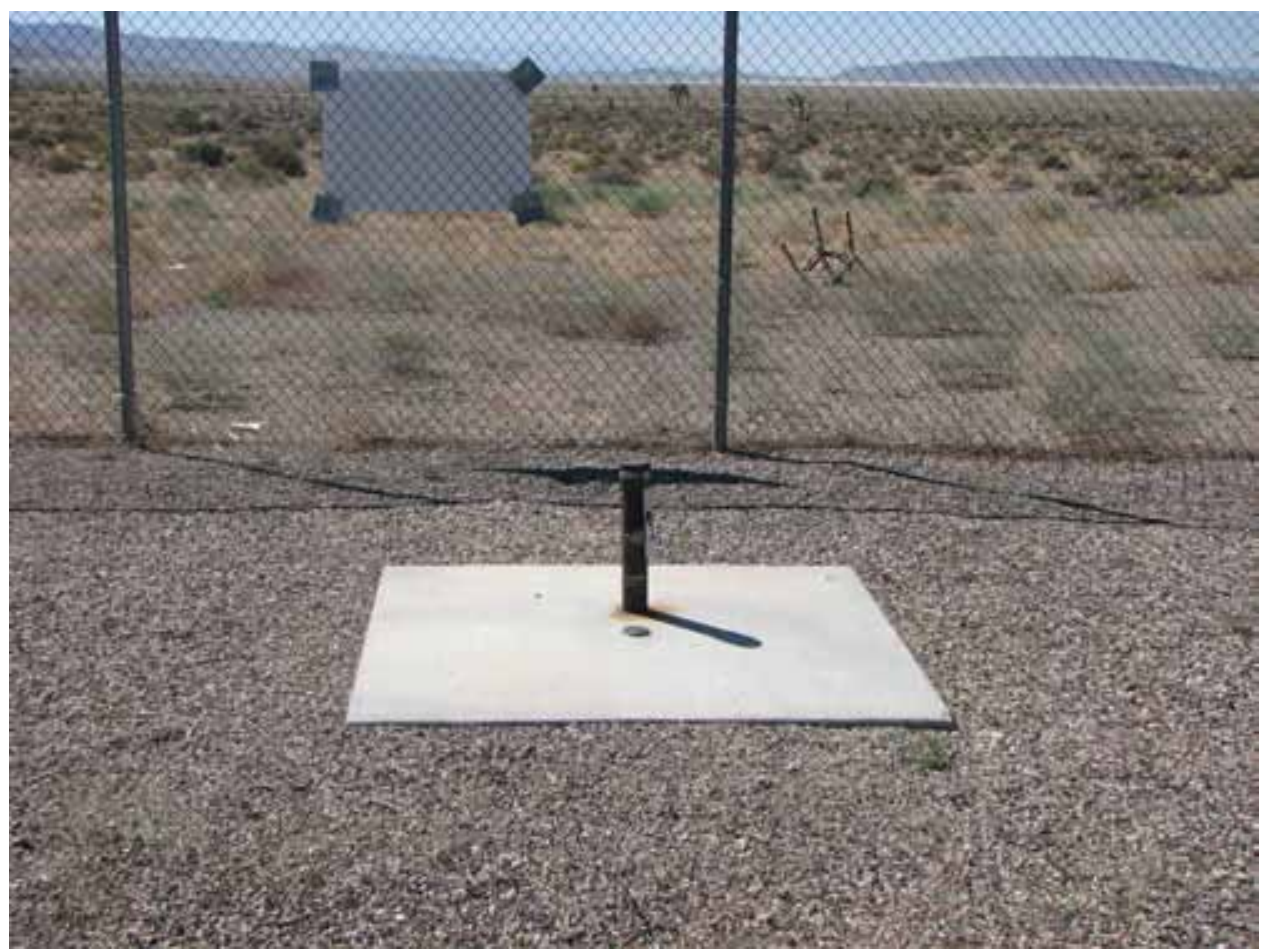

Photograph 28: CAU 91, Surface Monitoring Well Facing South, 09/08/2010 


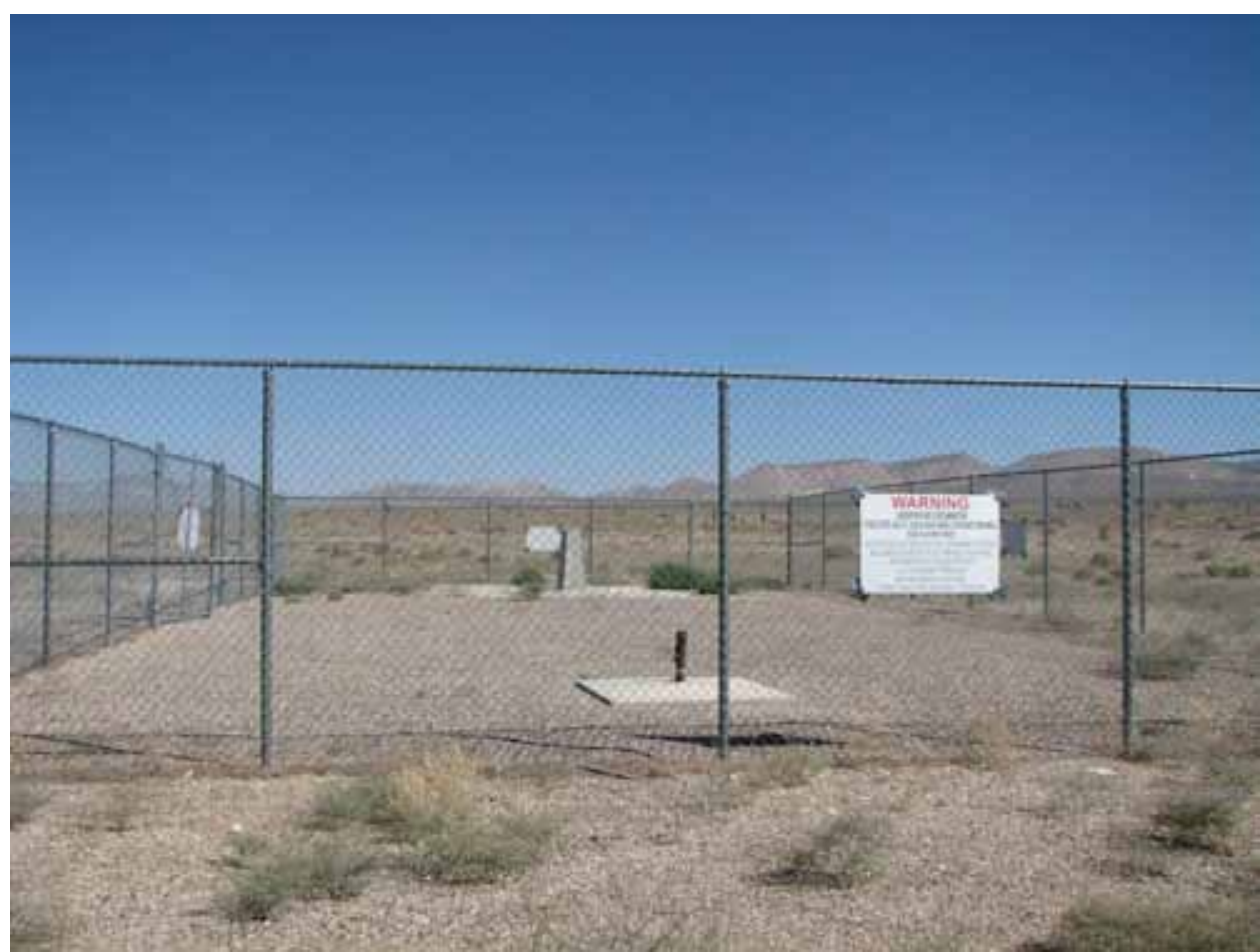

Photograph 29: CAU 91, Outside Facing North, 09/08/2010

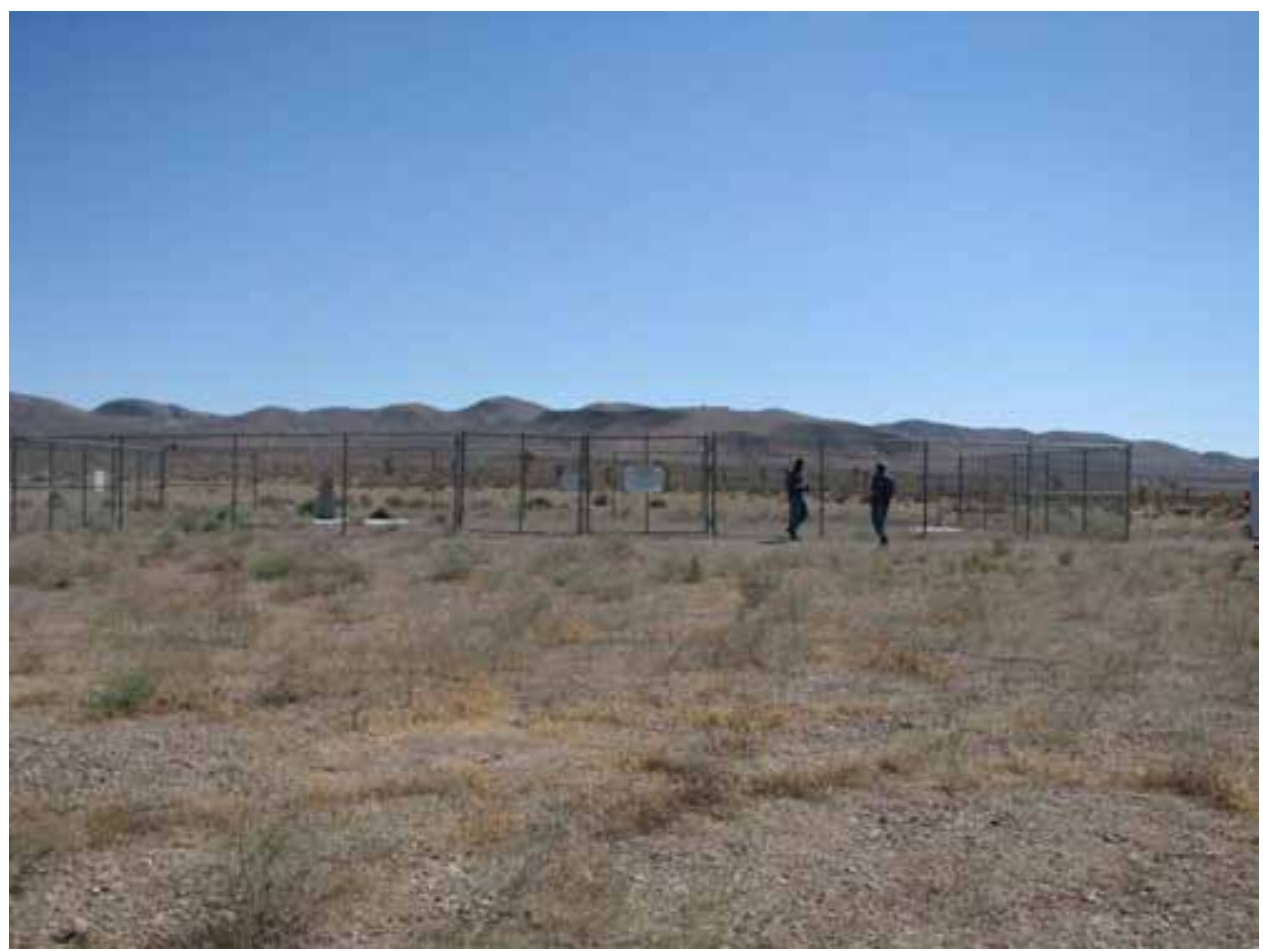

Photograph 30: CAU 91, Outside Facing East, 09/08/2010 


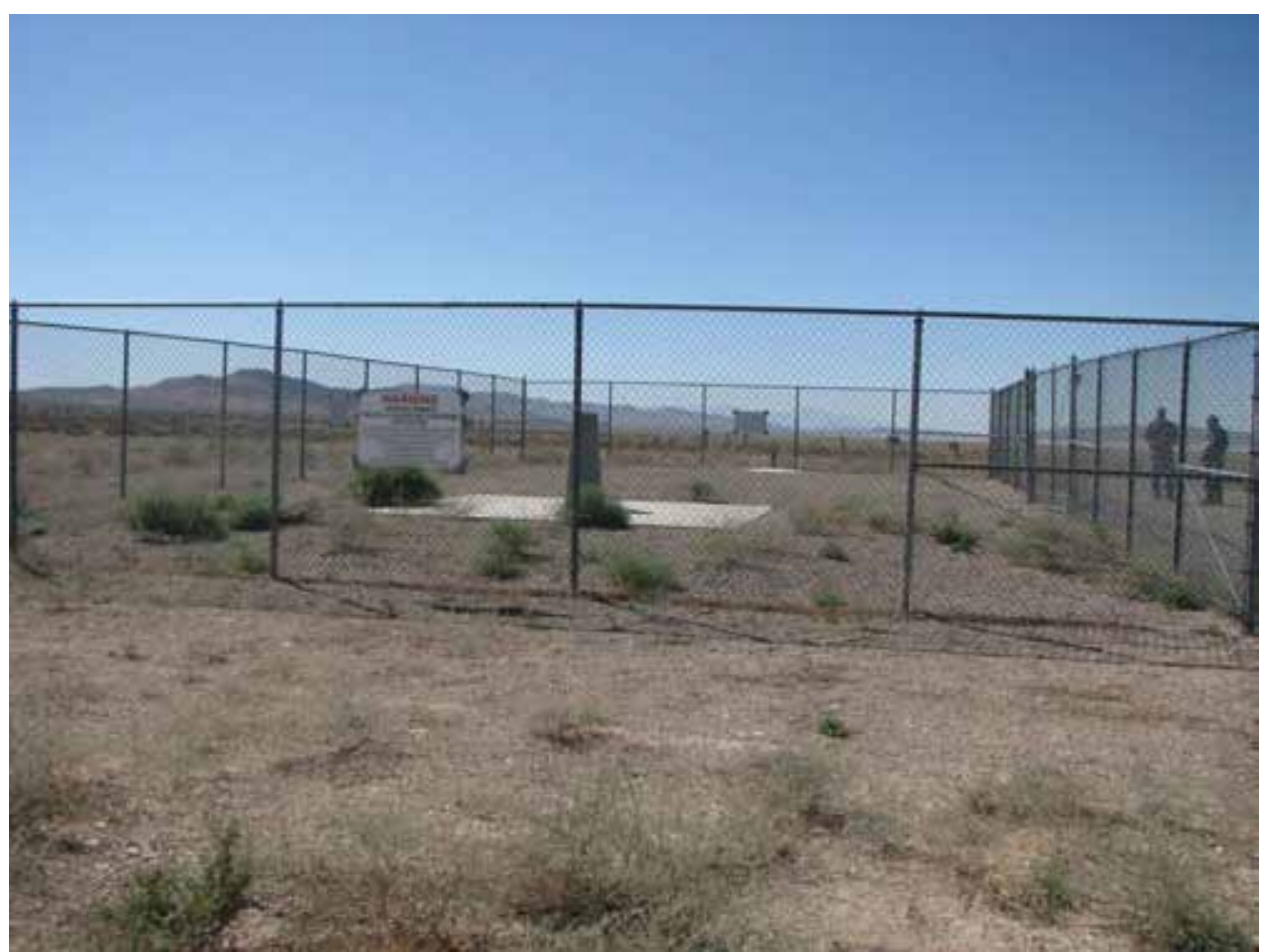

Photograph 31: CAU 91, Outside Facing South, 09/08/2010

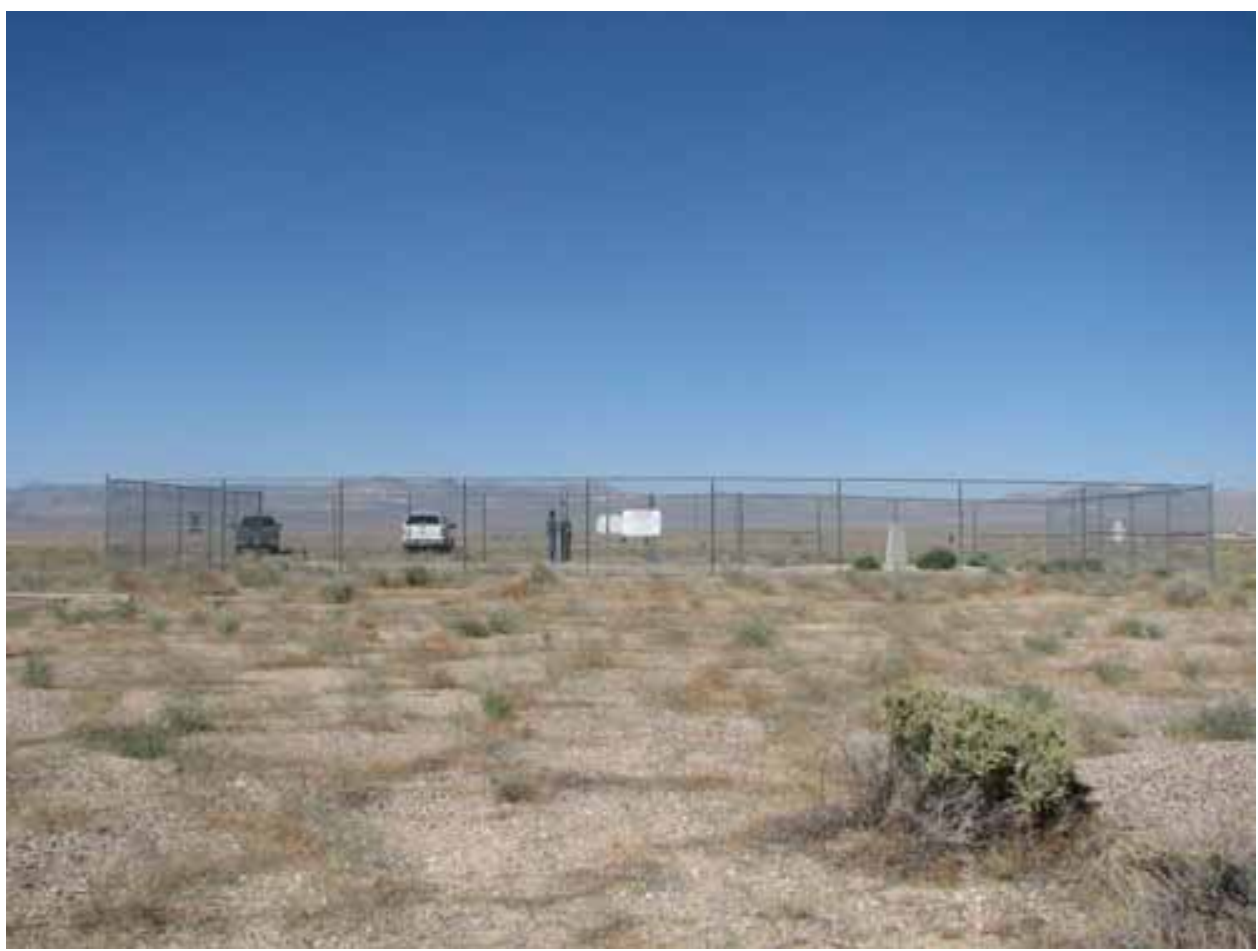

Photograph 32: CAU 91, Outside Facing West, 09/08/2010 


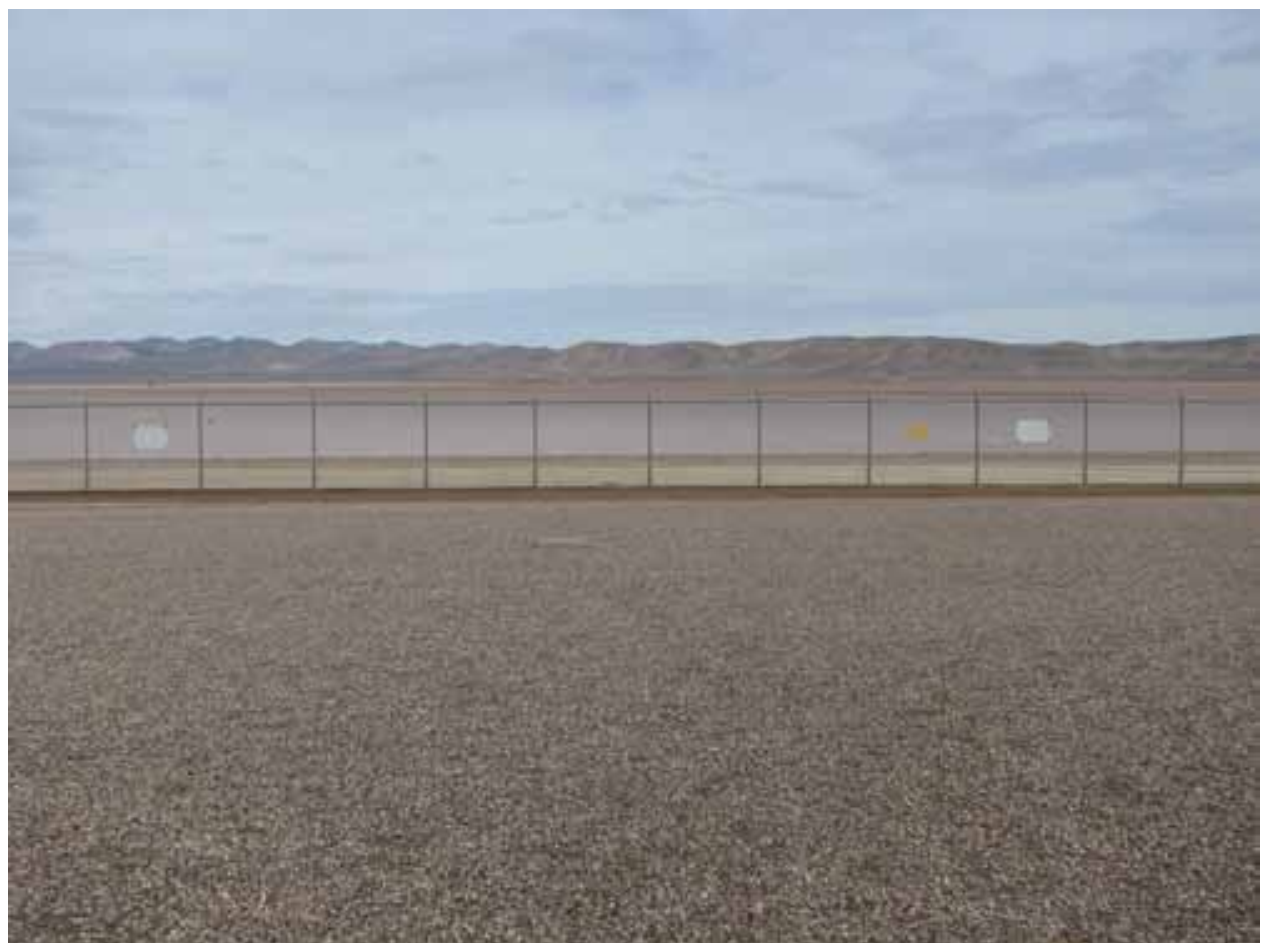

Photograph 33: CAU 92, Inside Facing North, 12/15/2009

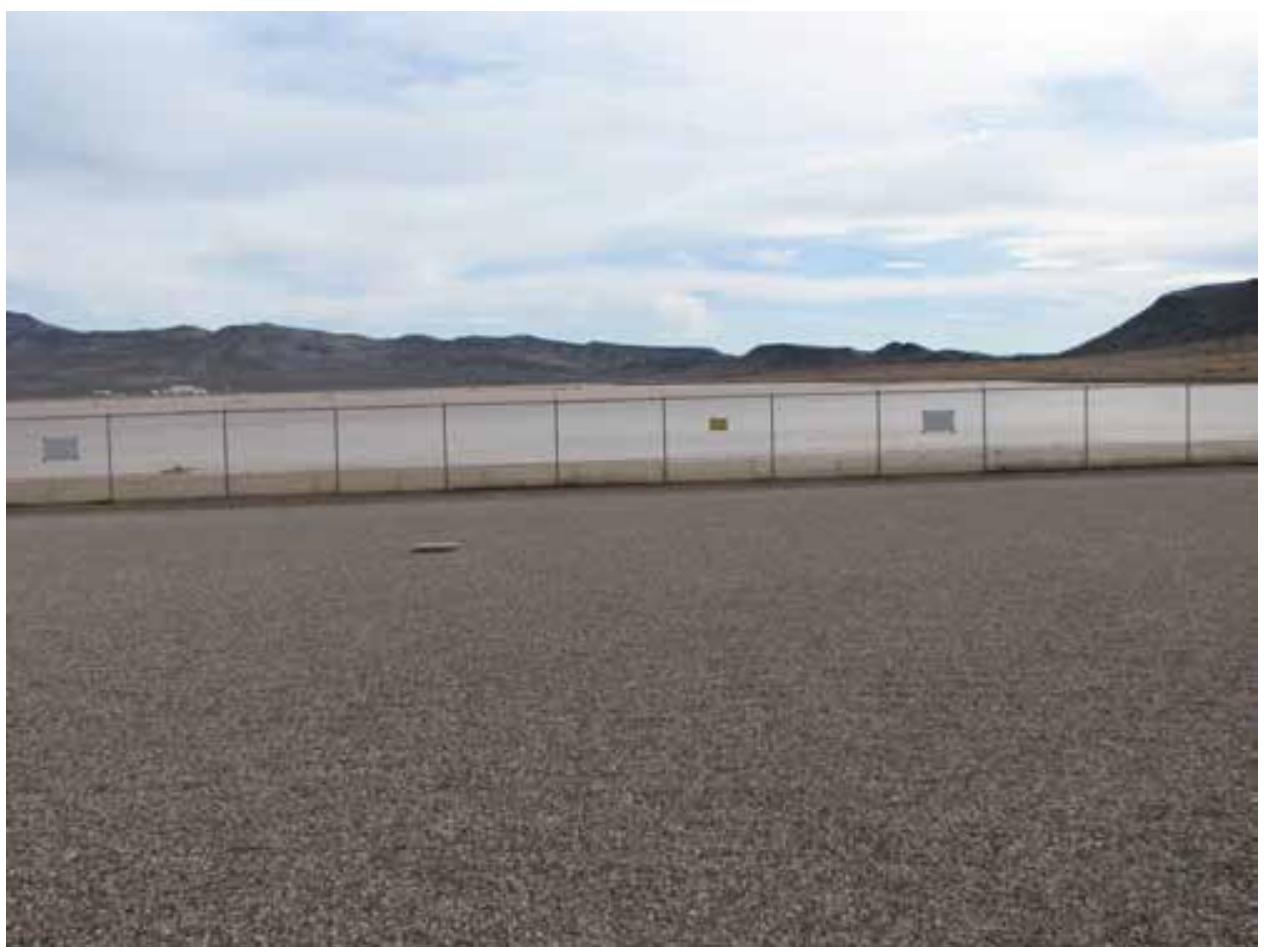

Photograph 34: CAU 92, Inside Facing East, 12/15/2009 


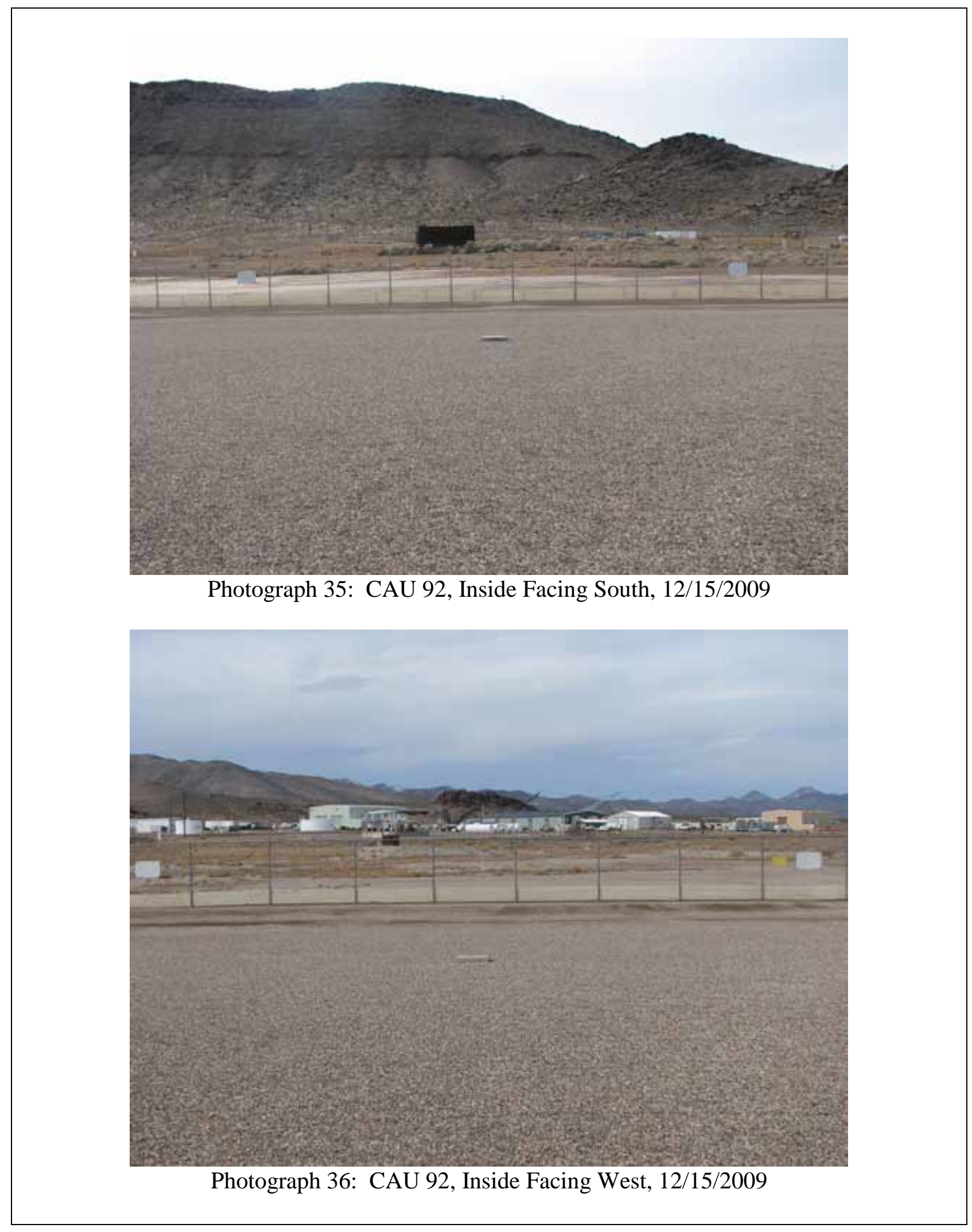




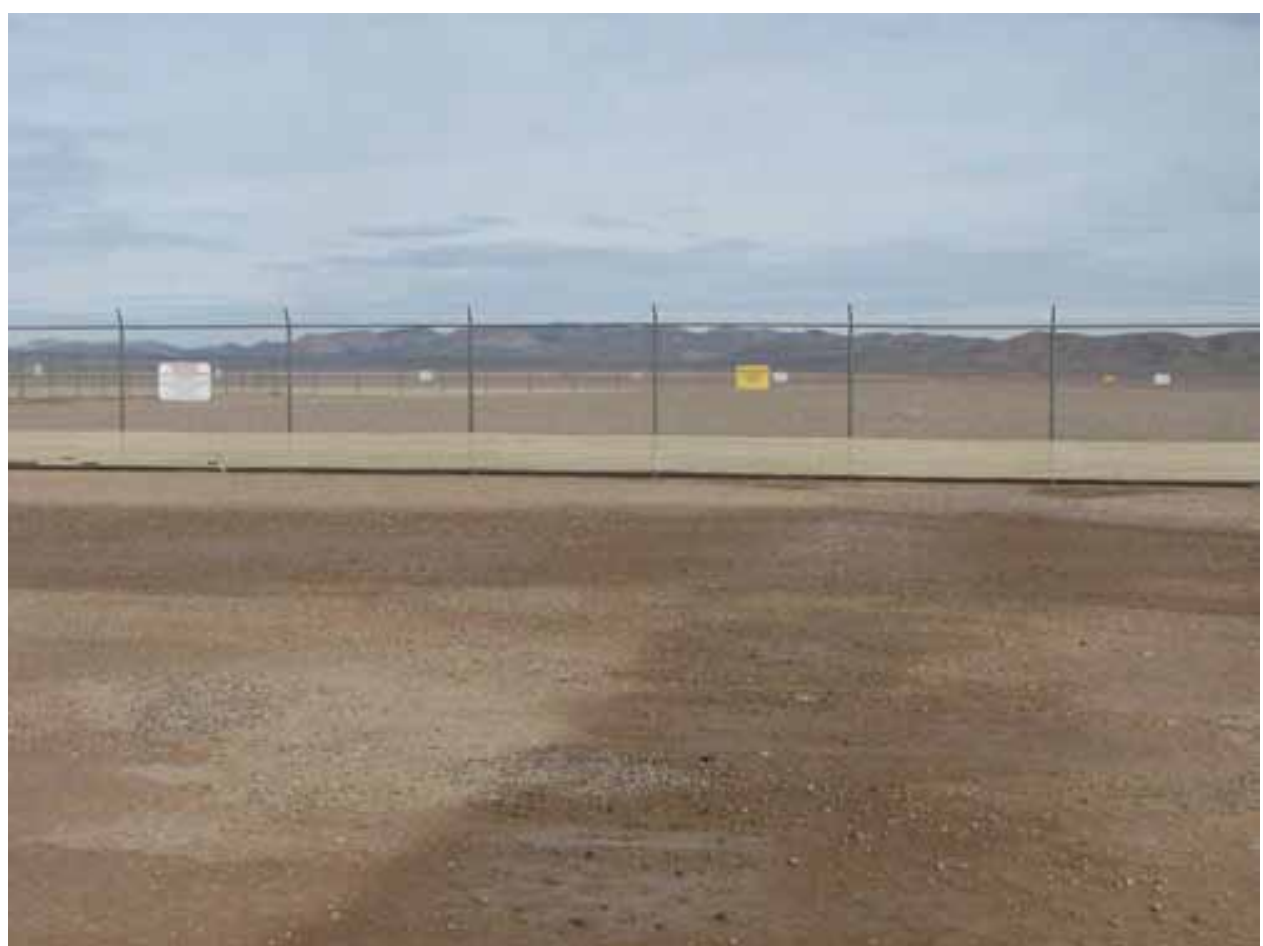

Photograph 37: CAU 92, Outside Facing North, 12/15/2009

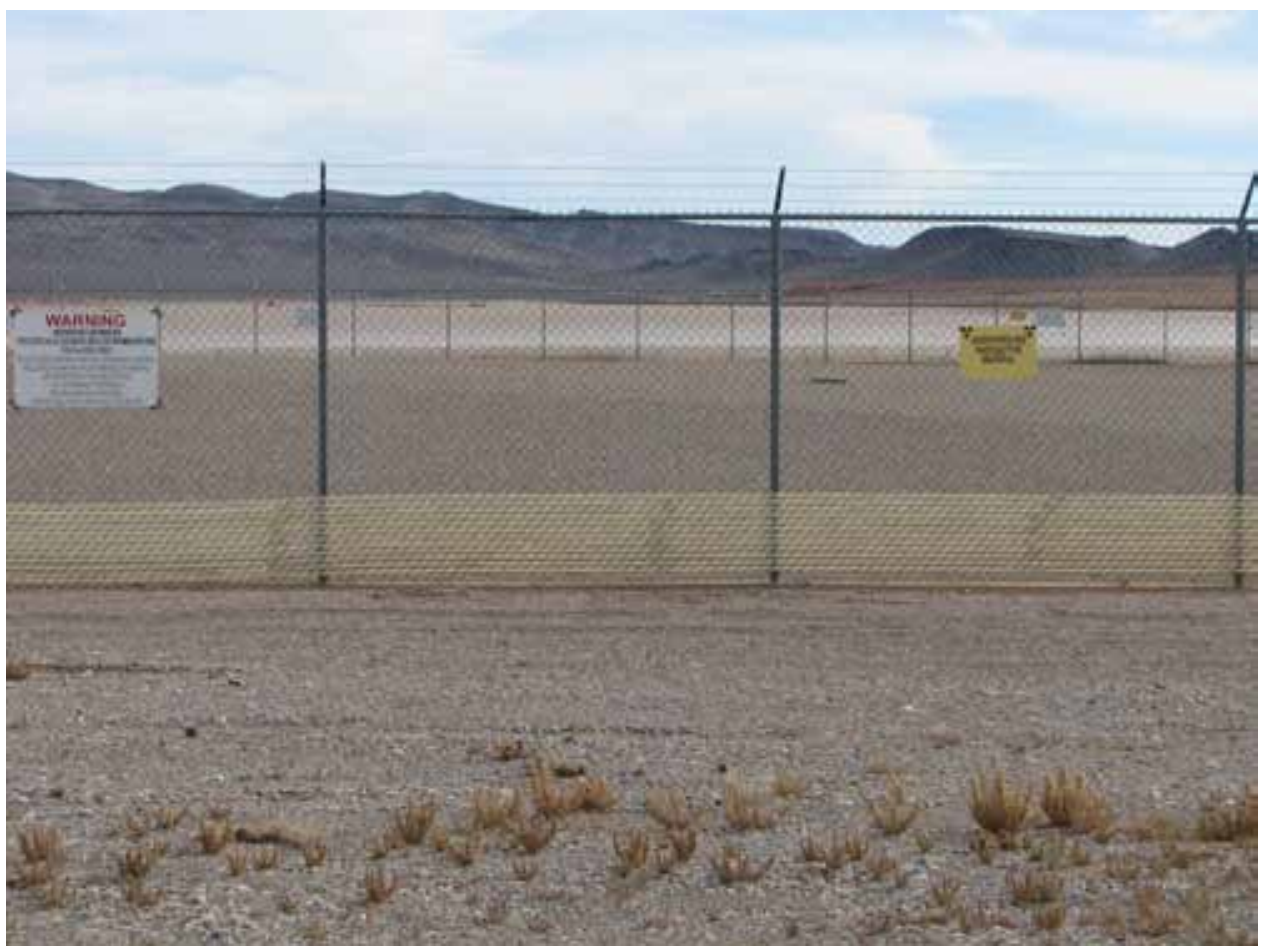

Photograph 38: CAU 92, Outside Facing East, 12/15/2009 


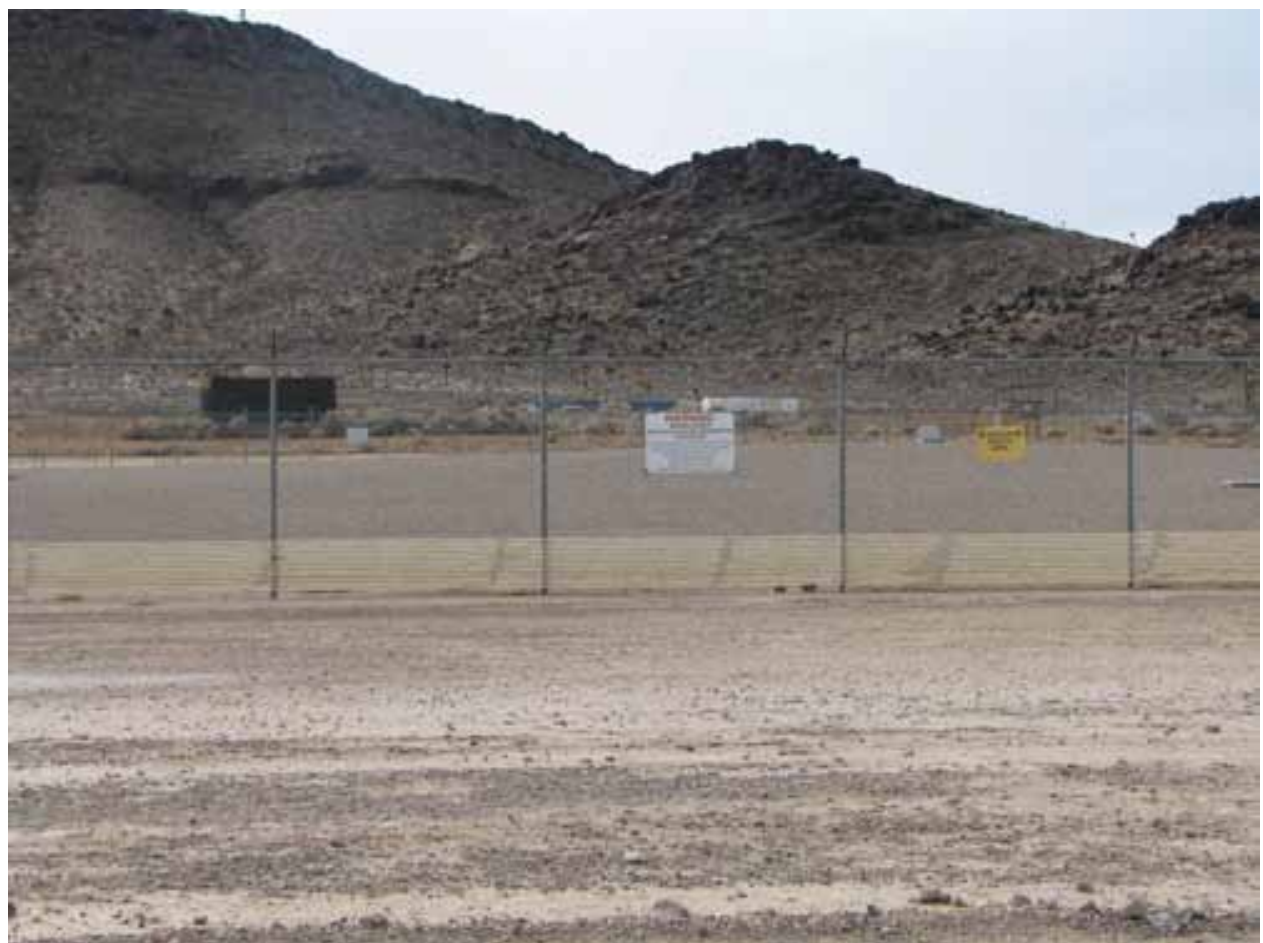

Photograph 39: CAU 92, Outside Facing South, 12/15/2009

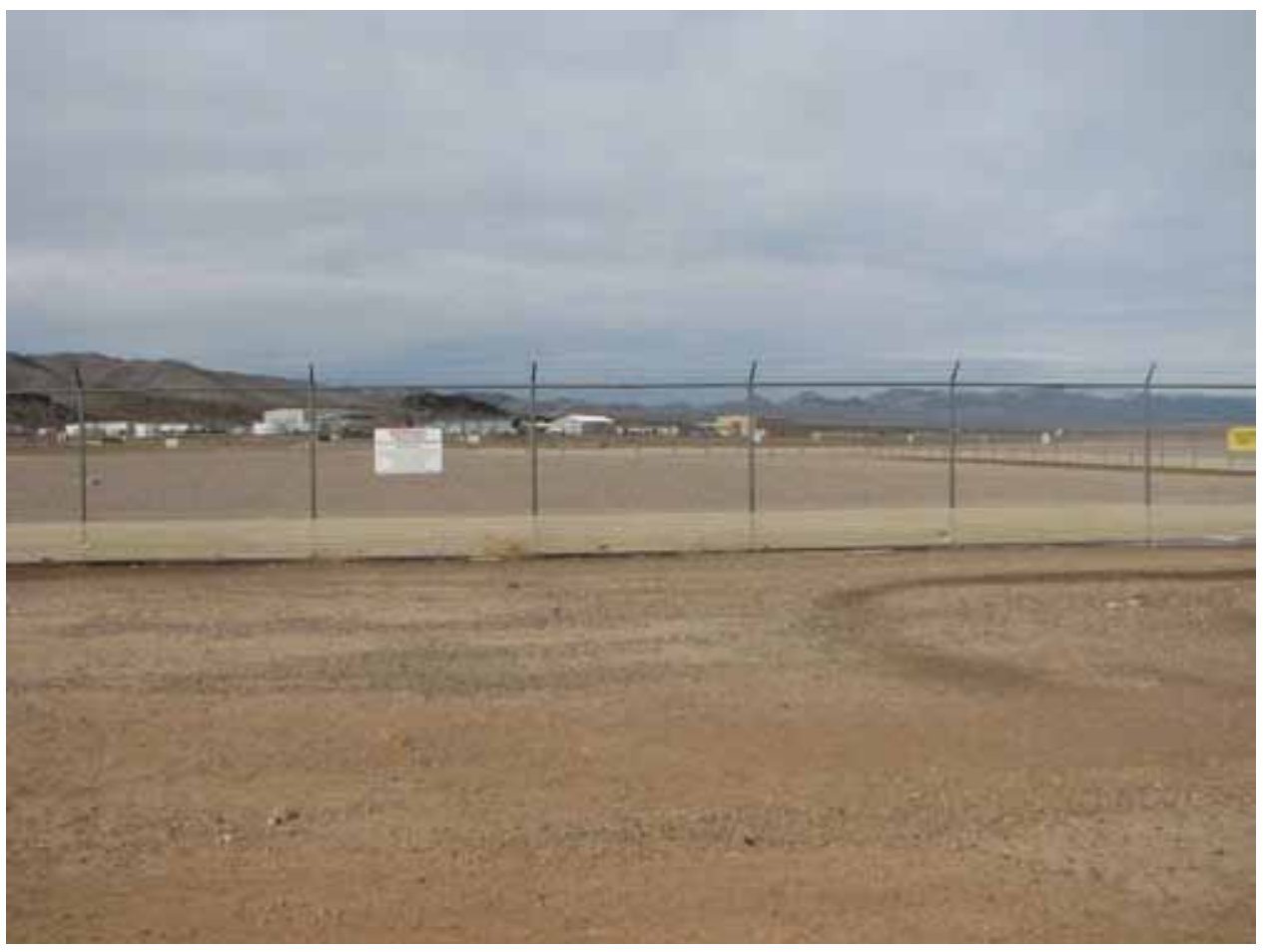

Photograph 40: CAU 92, Outside Facing West, 12/15/2009 
RCRA Post-Closure Report

Revision: 0

Date: January 2011

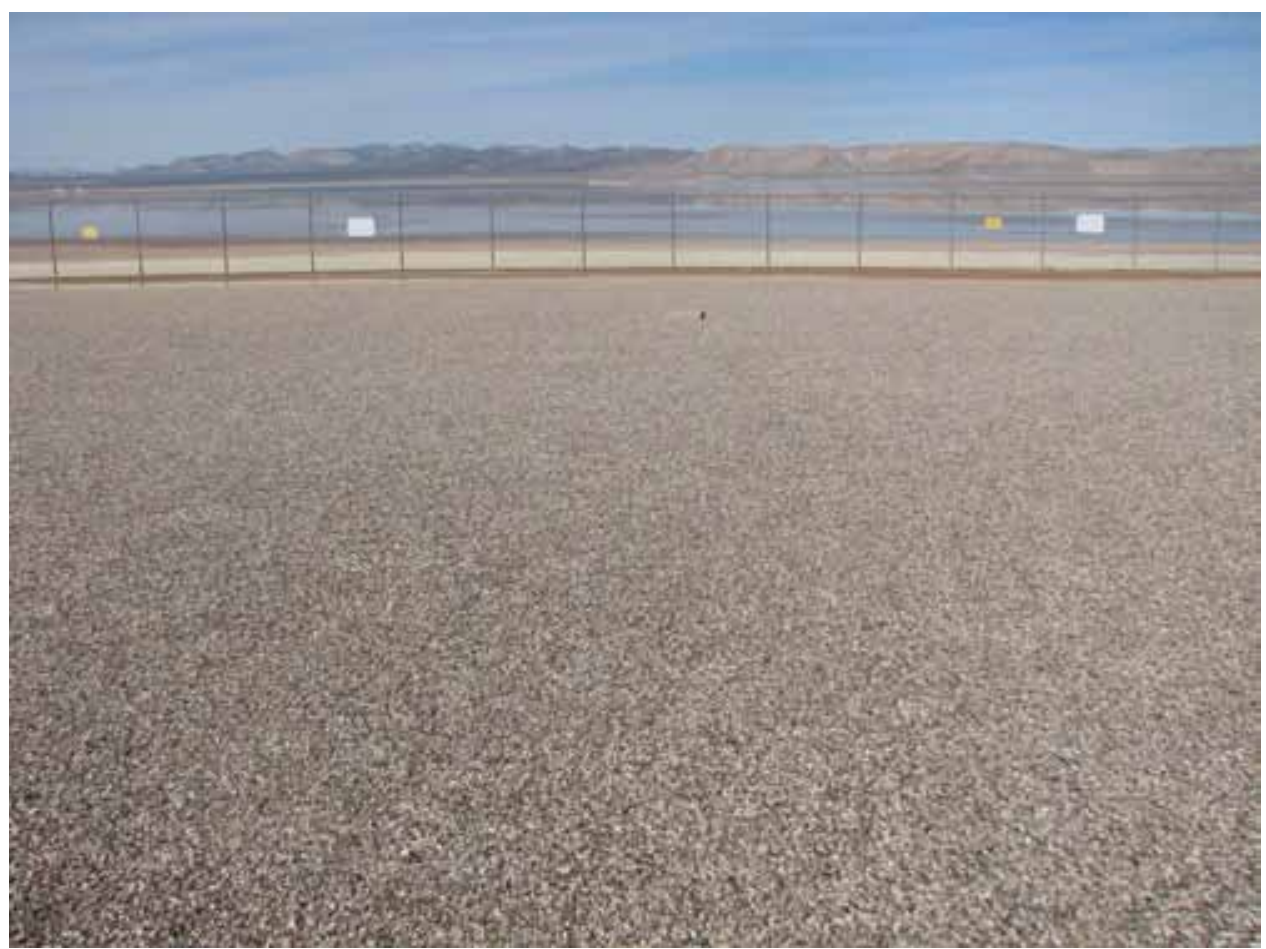

Photograph 41: CAU 92, Inside Facing North, 03/17/2010

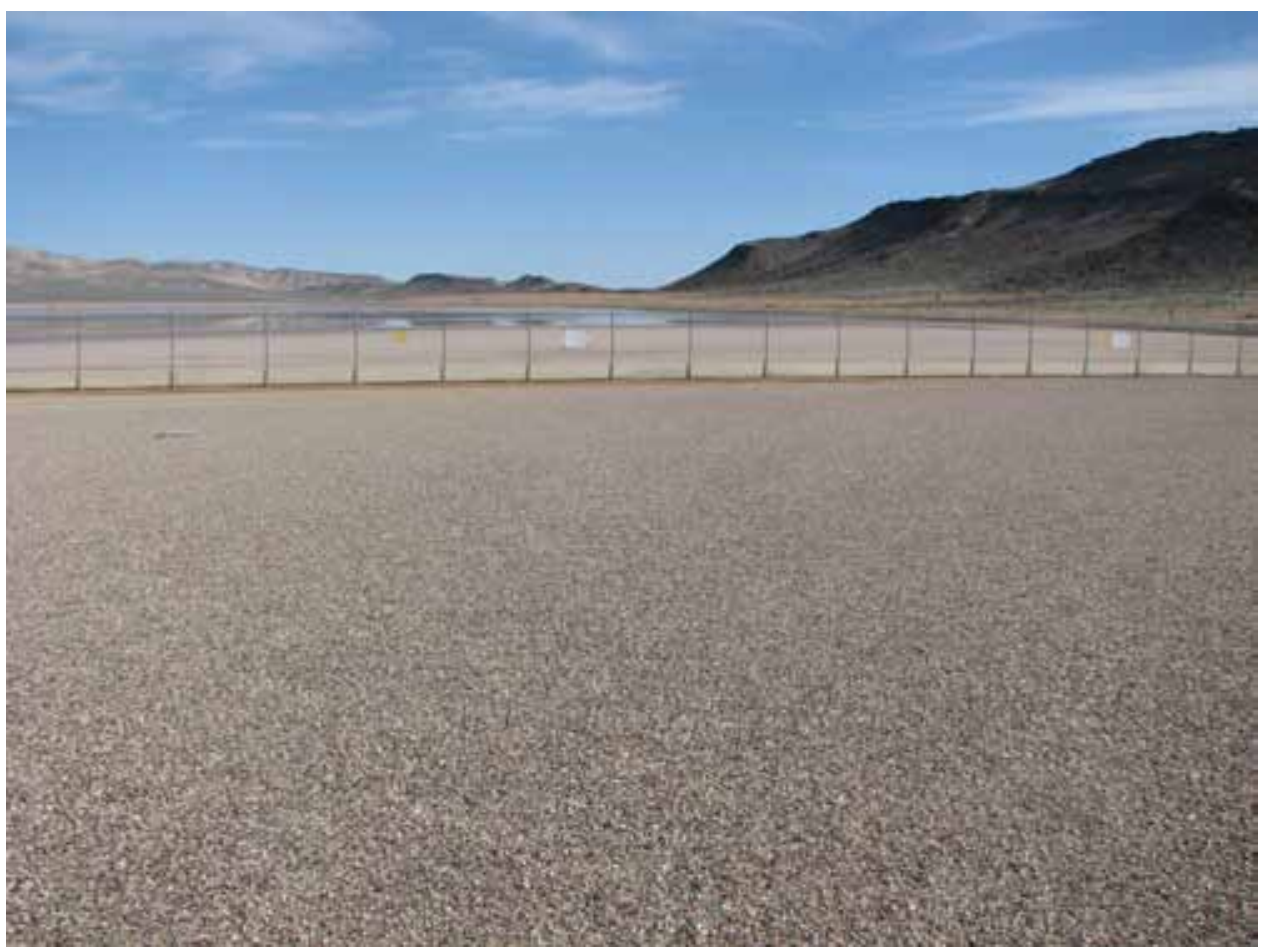

Photograph 42: CAU 92, Inside Facing East, 03/17/2010 


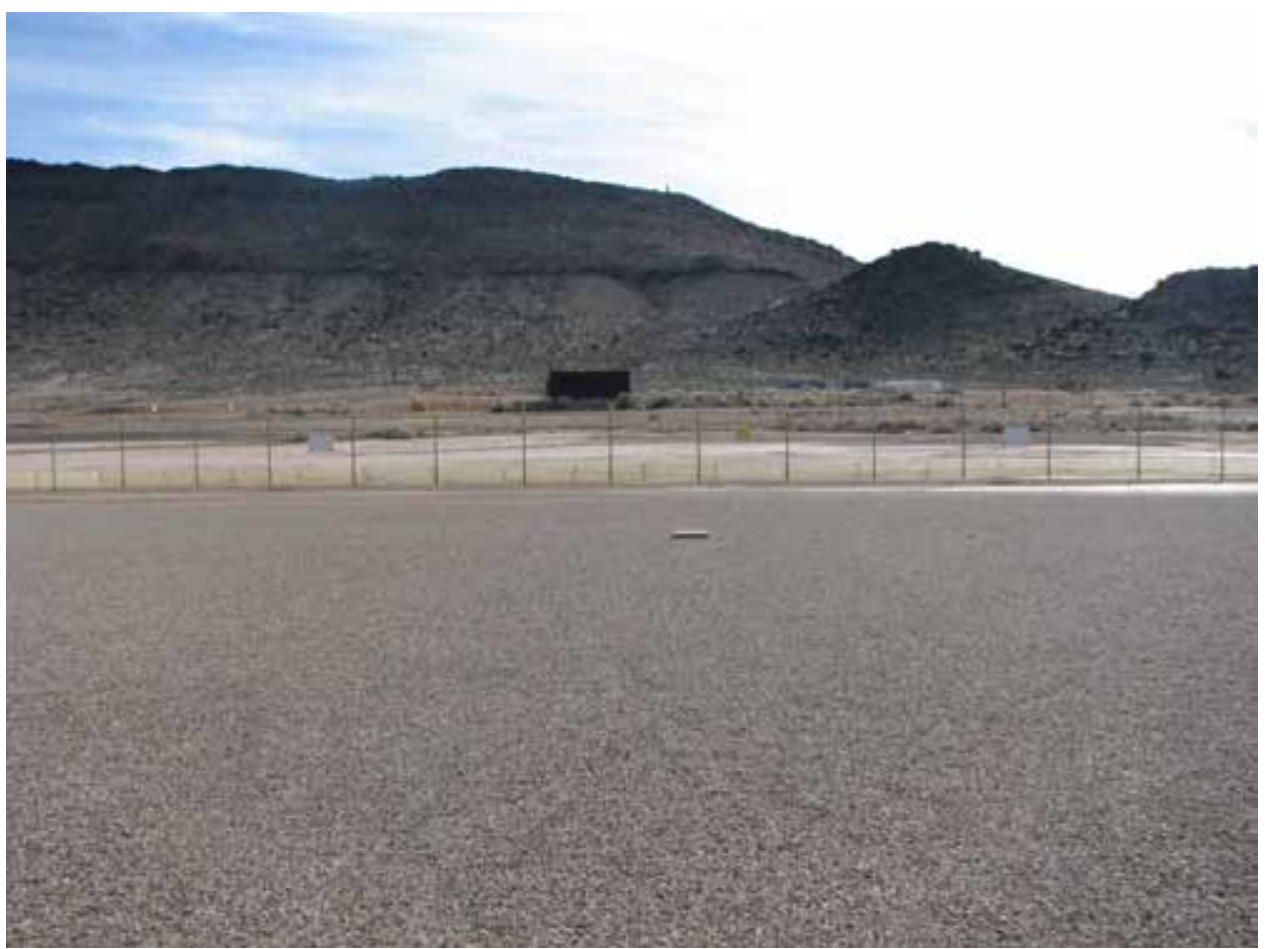

Photograph 43: CAU 92, Inside Facing South, 03/17/2010

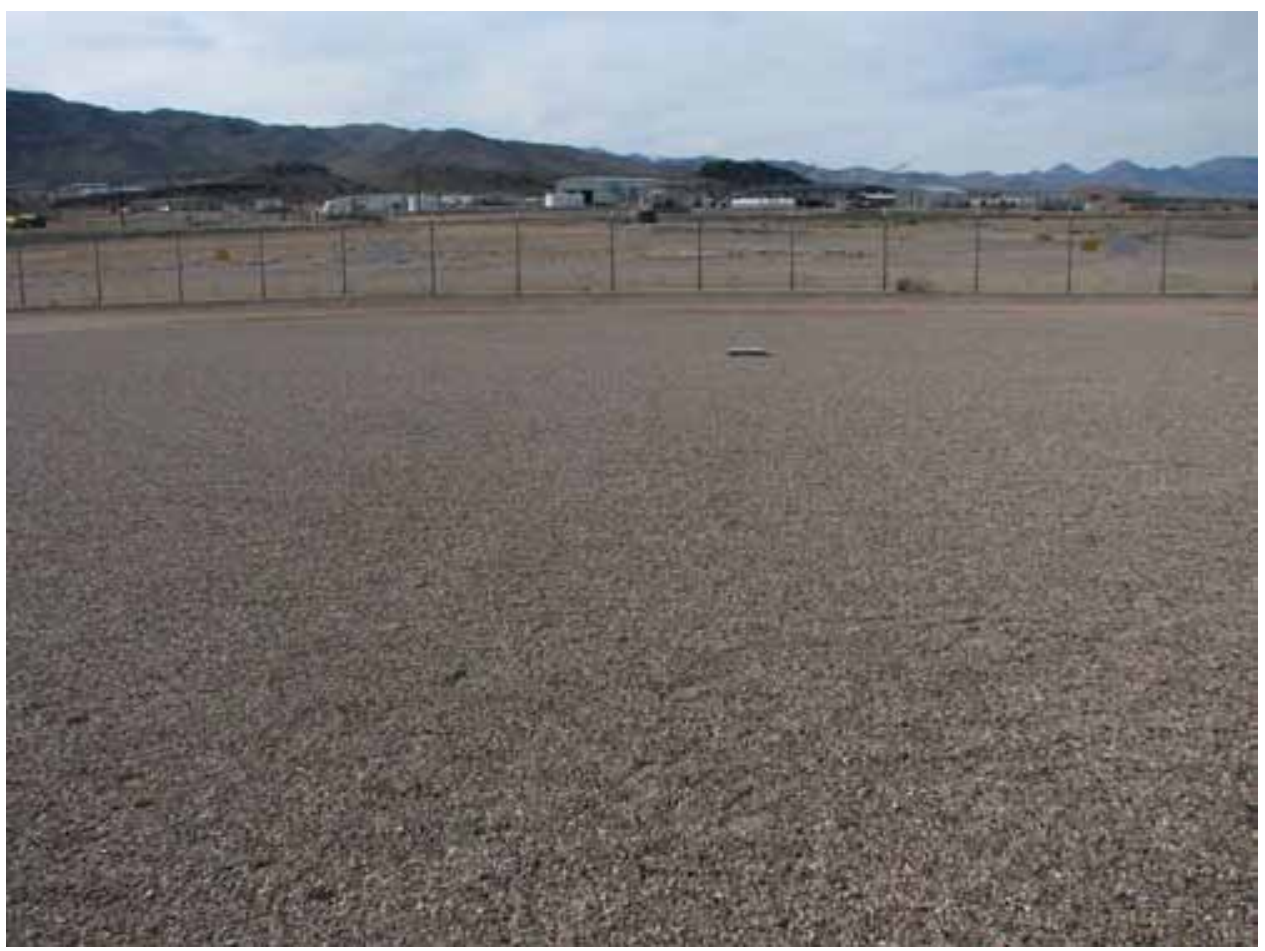

Photograph 44: CAU 92, Inside Facing West, 03/17/2010 


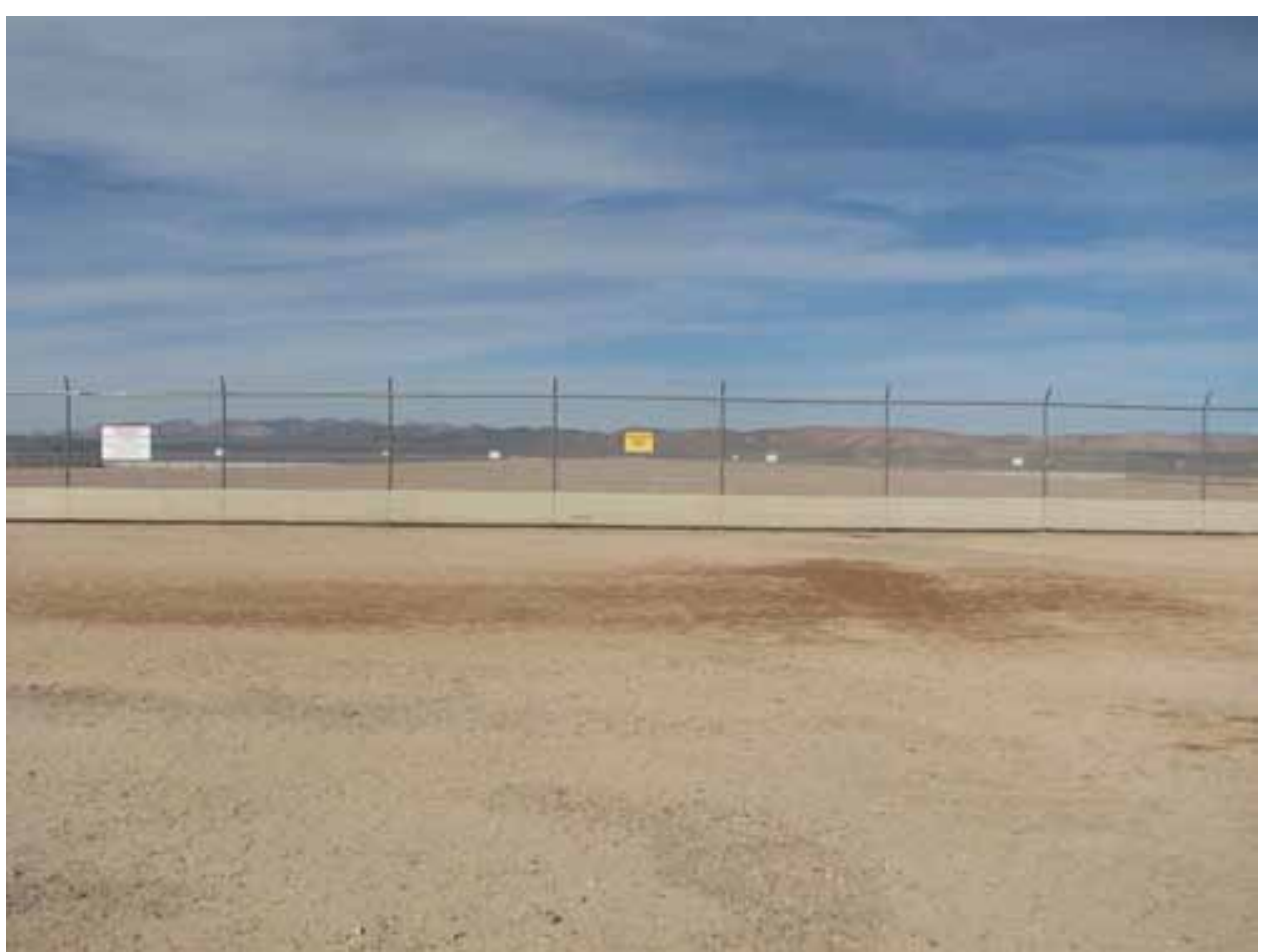

Photograph 45: CAU 92, Outside Facing North, 03/17/2010

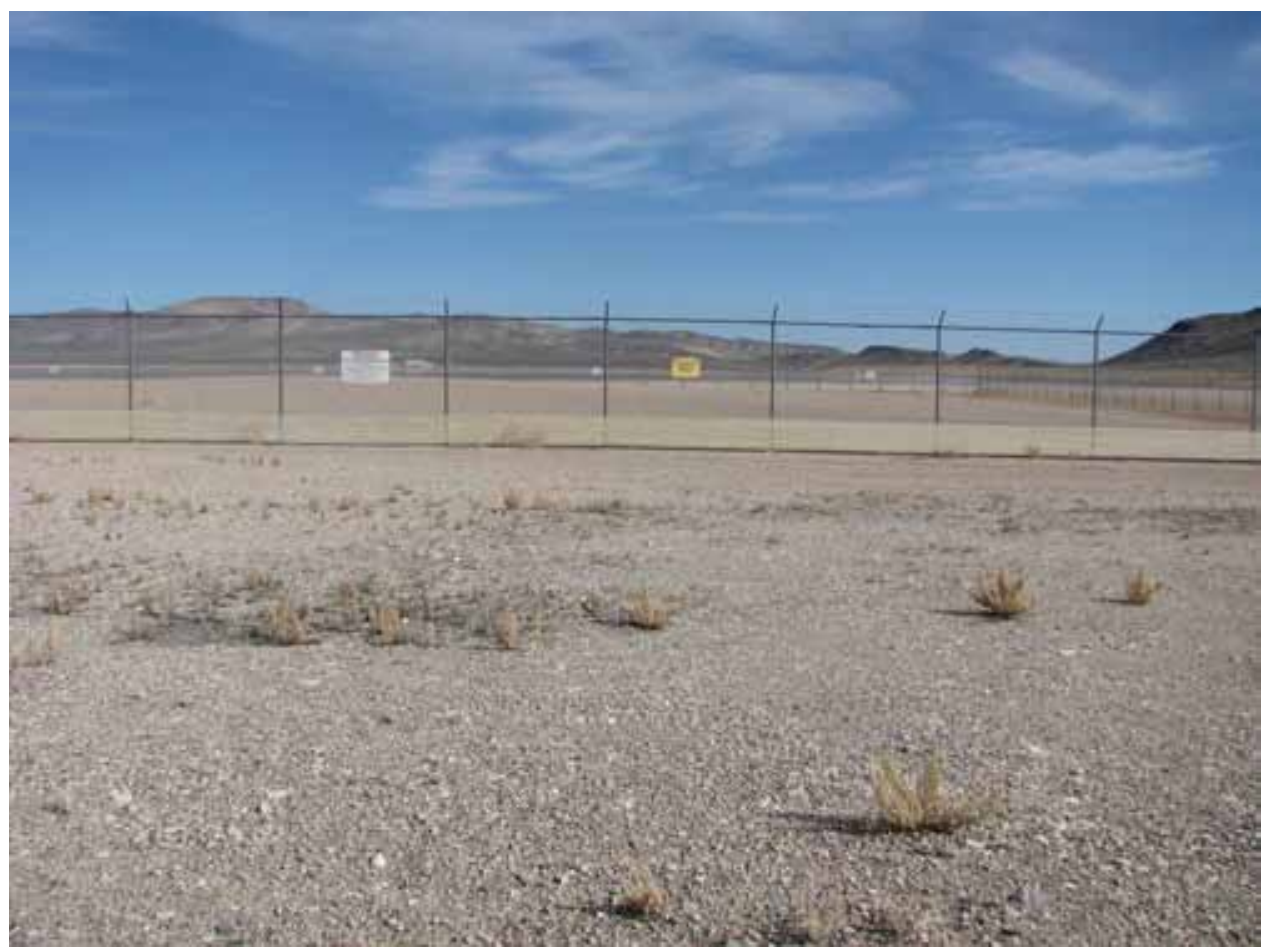

Photograph 46: CAU 92, Outside Facing East, 03/17/2010 


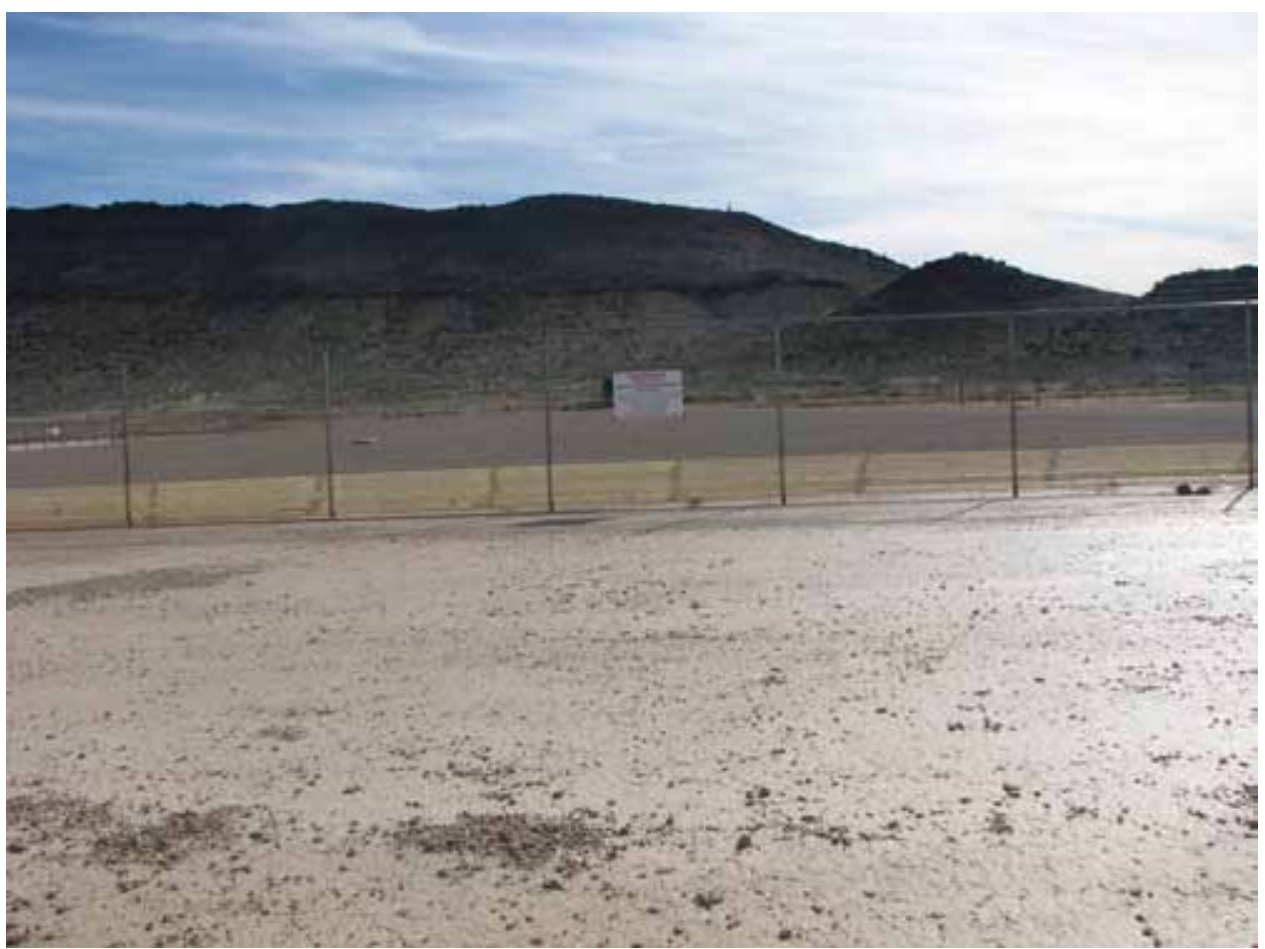

Photograph 47: CAU 92, Outside Facing South, 03/17/2010

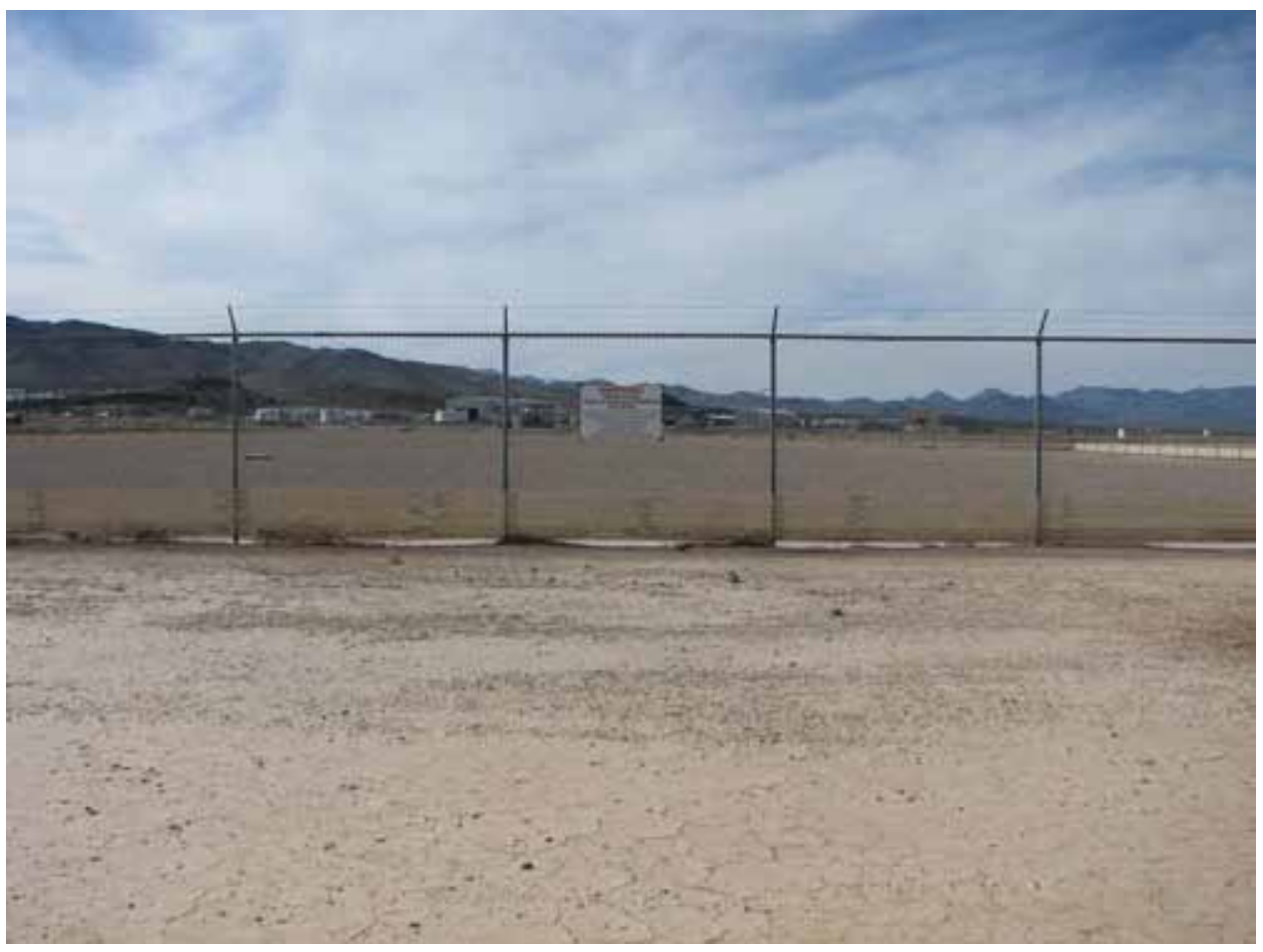

Photograph 48: CAU 92, Outside Facing West, 03/17/2010 


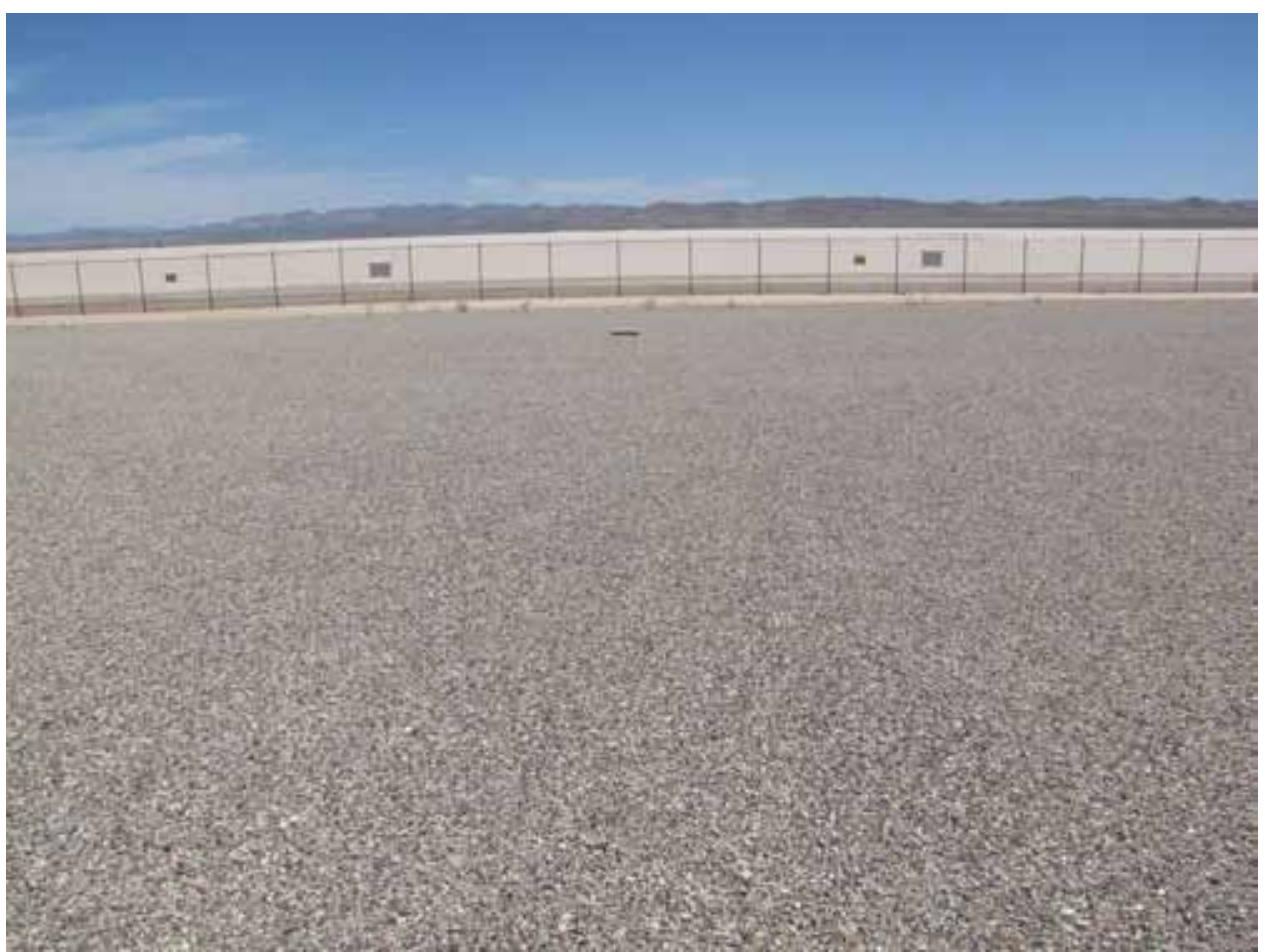

Photograph 49: CAU 92, Inside Facing North, 06/23/2010

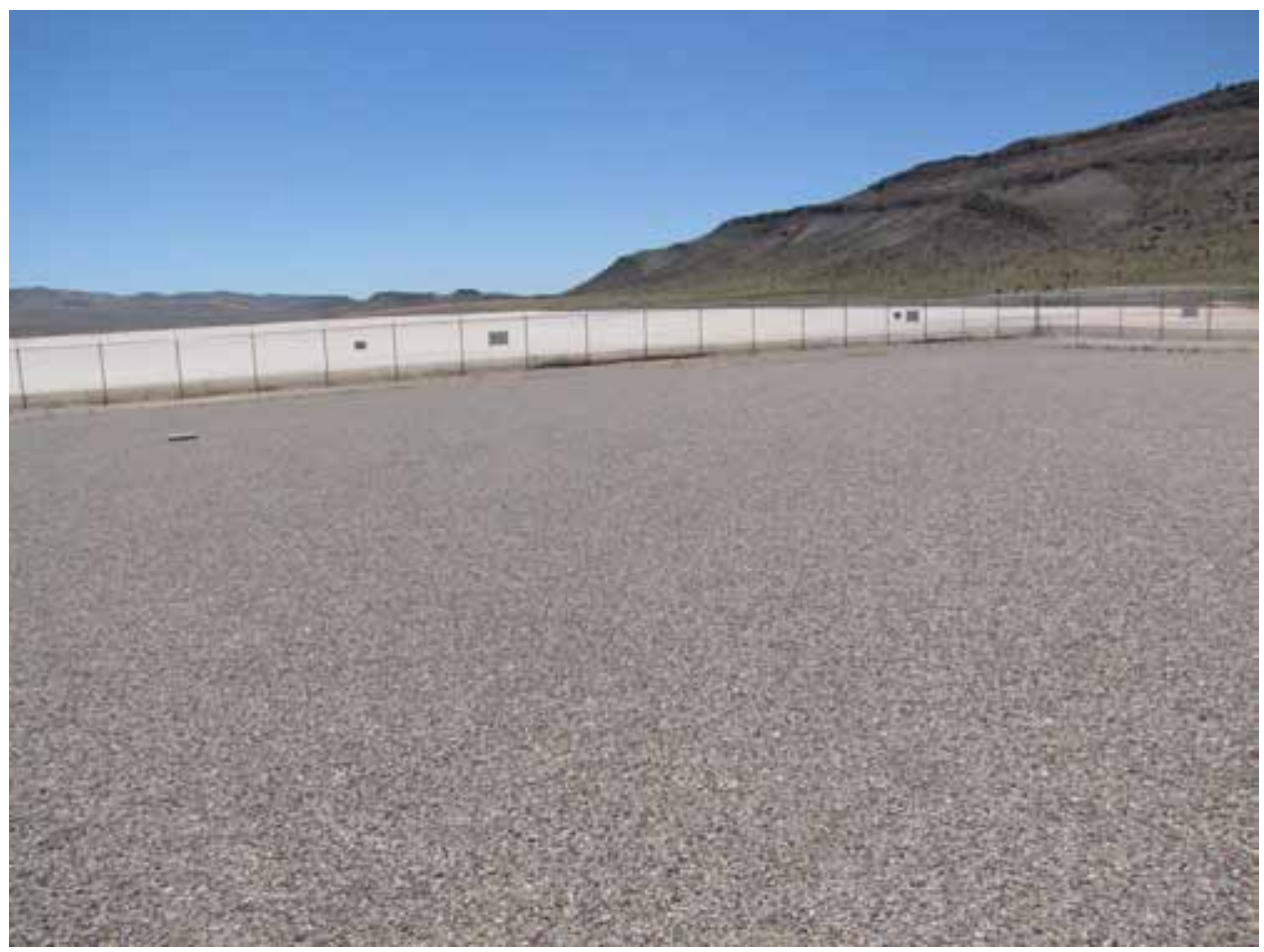

Photograph 50: CAU 92, Inside Facing East, 06/23/2010 
RCRA Post-Closure Report

Revision: 0

Date: January 2011

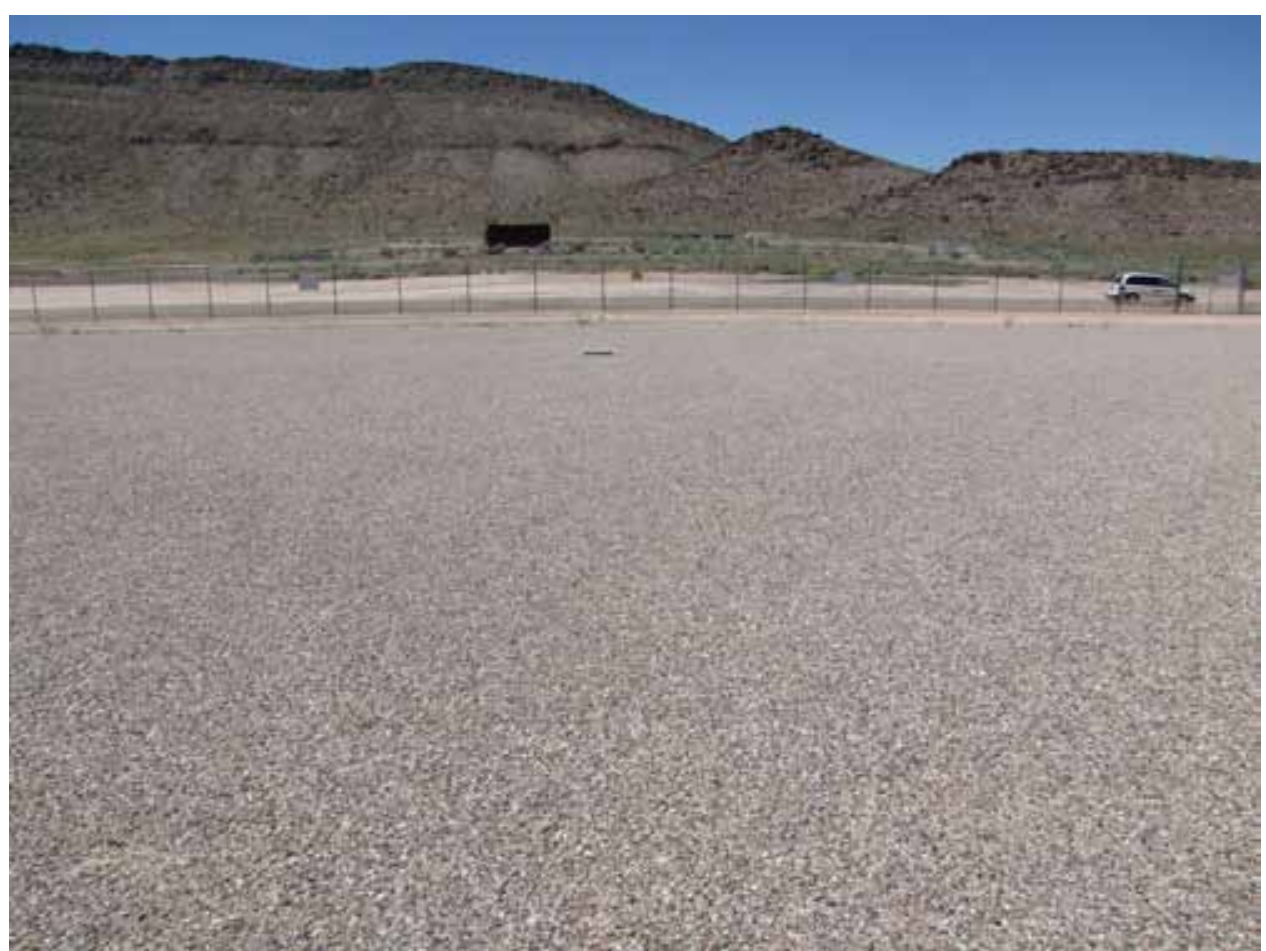

Photograph 51: CAU 92, Inside Facing South, 06/23/2010

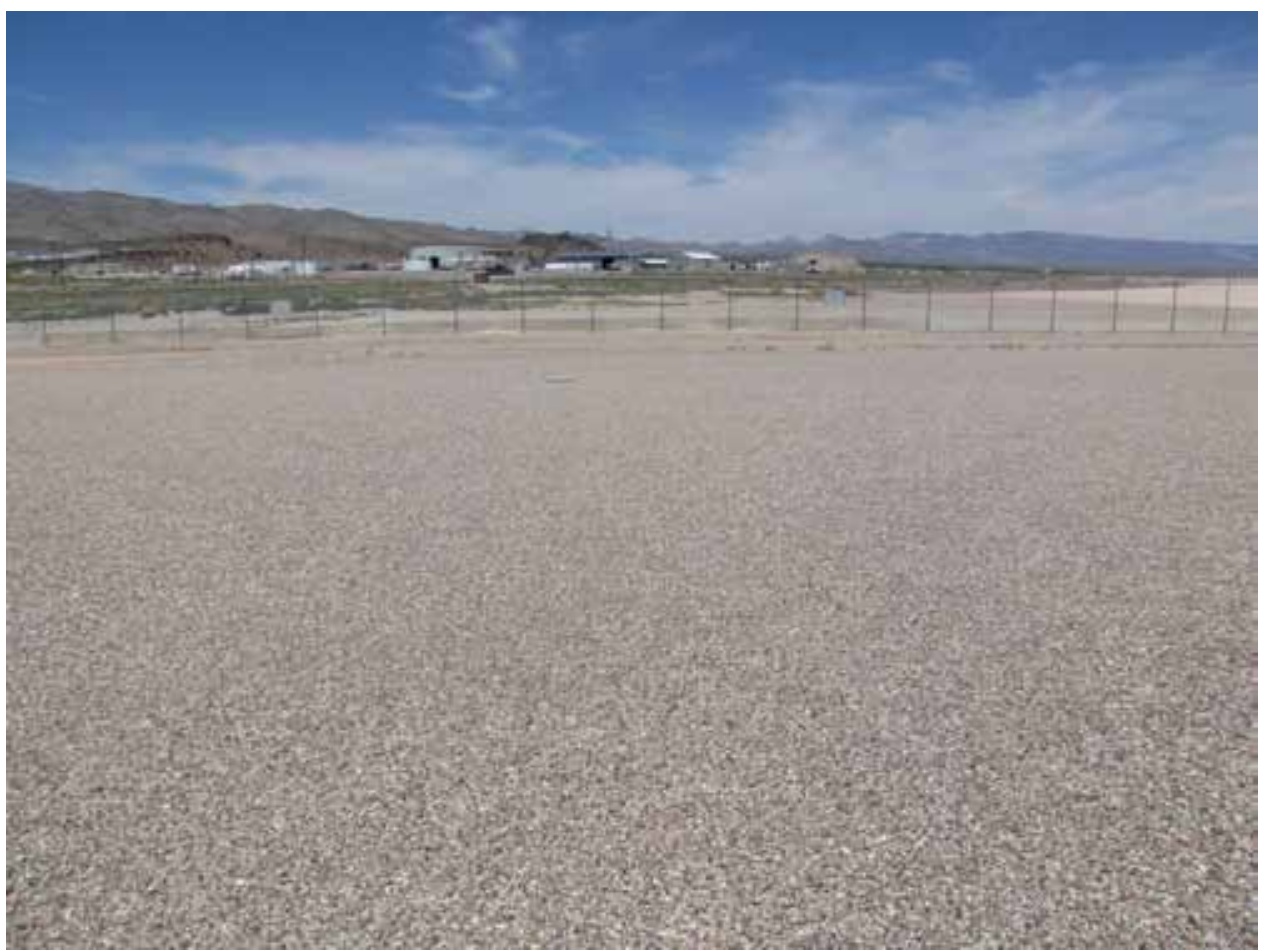

Photograph 52: CAU 92, Inside Facing West, 06/23/2010 


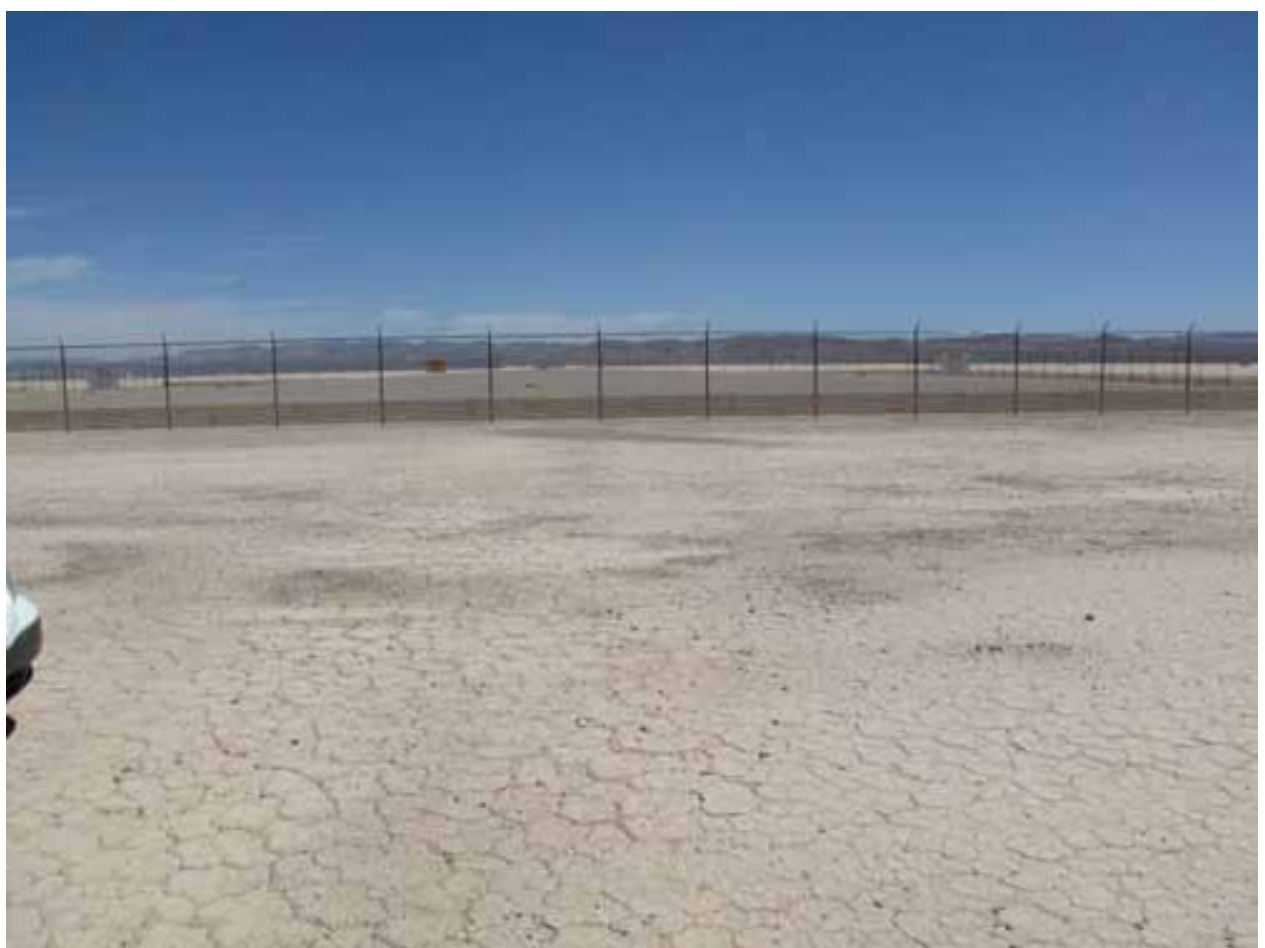

Photograph 53: CAU 92, Outside Facing North, 06/23/2010

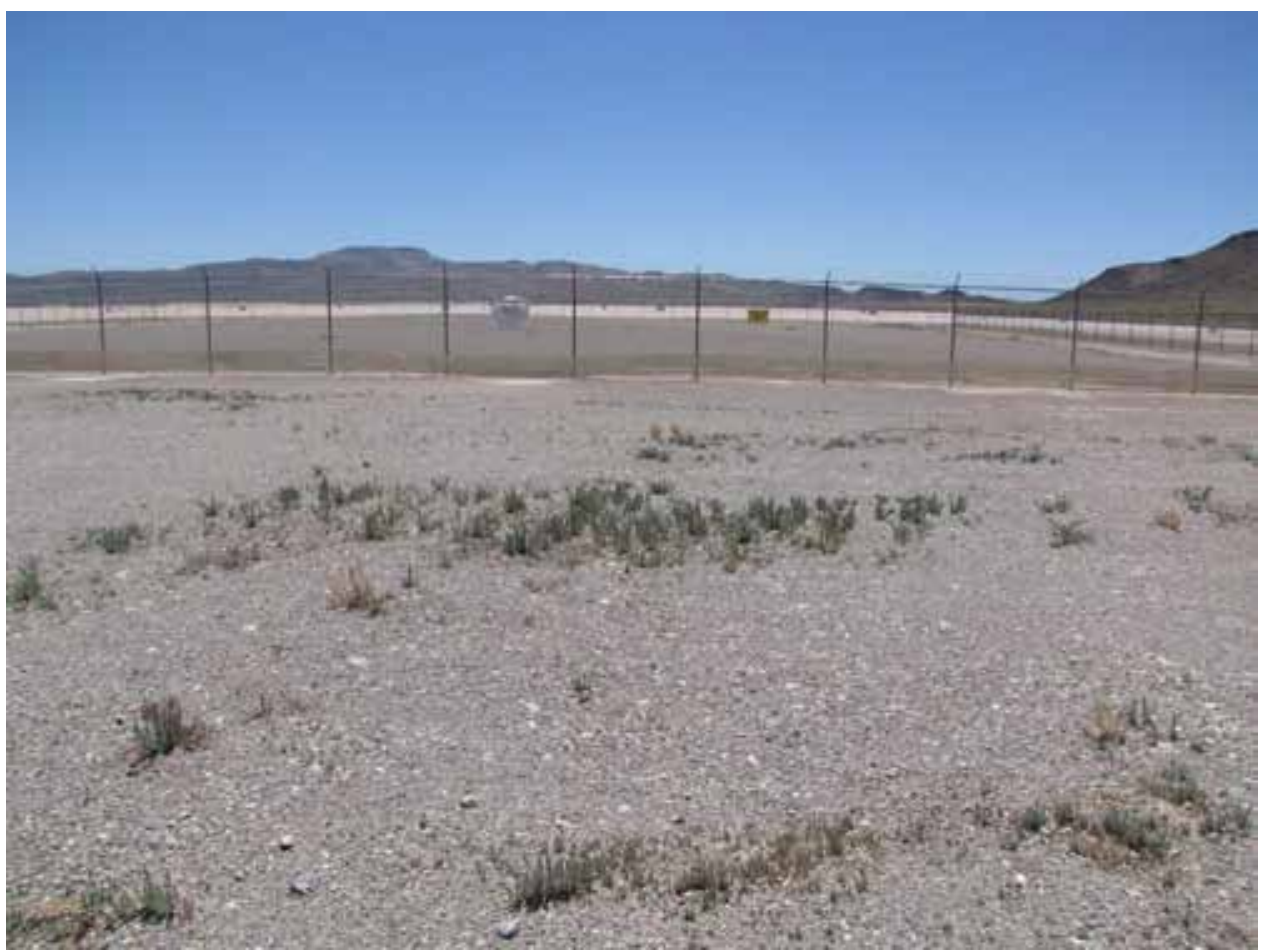

Photograph 54: CAU 92, Outside Facing East, 06/23/2010 


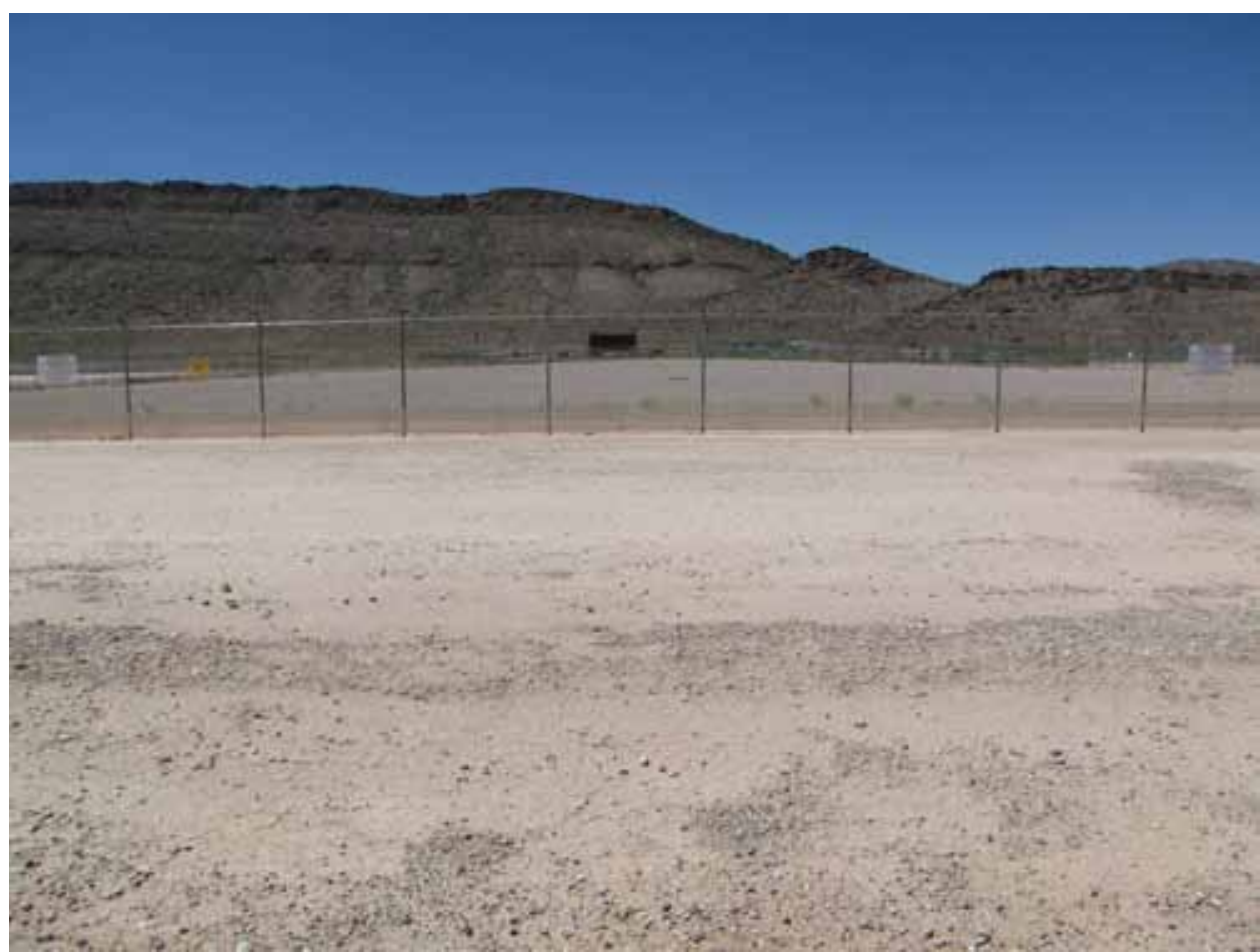

Photograph 55: CAU 92, Outside Facing South, 06/23/2010

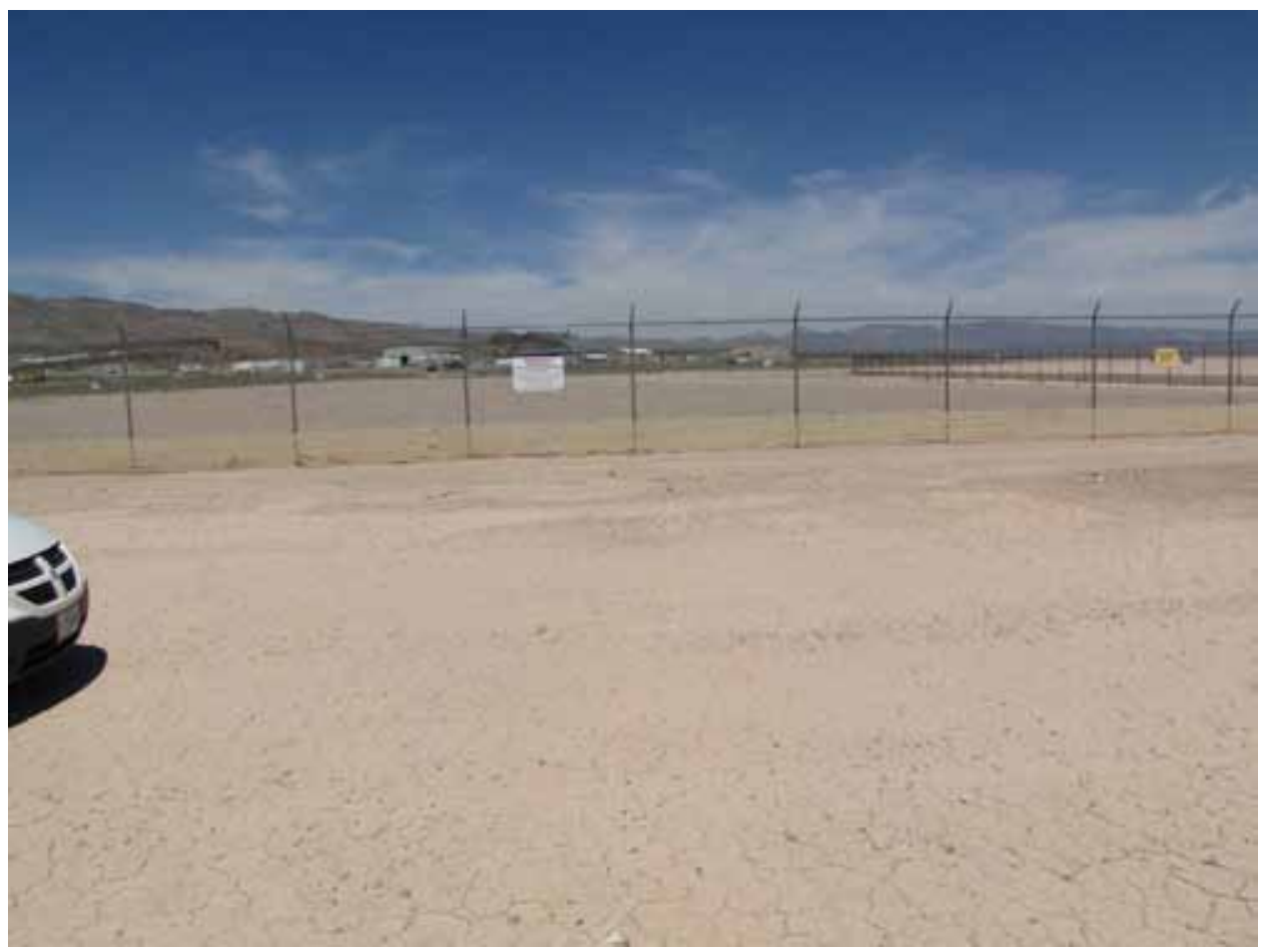

Photograph 56: CAU 92, Outside Facing West, 06/23/2010 


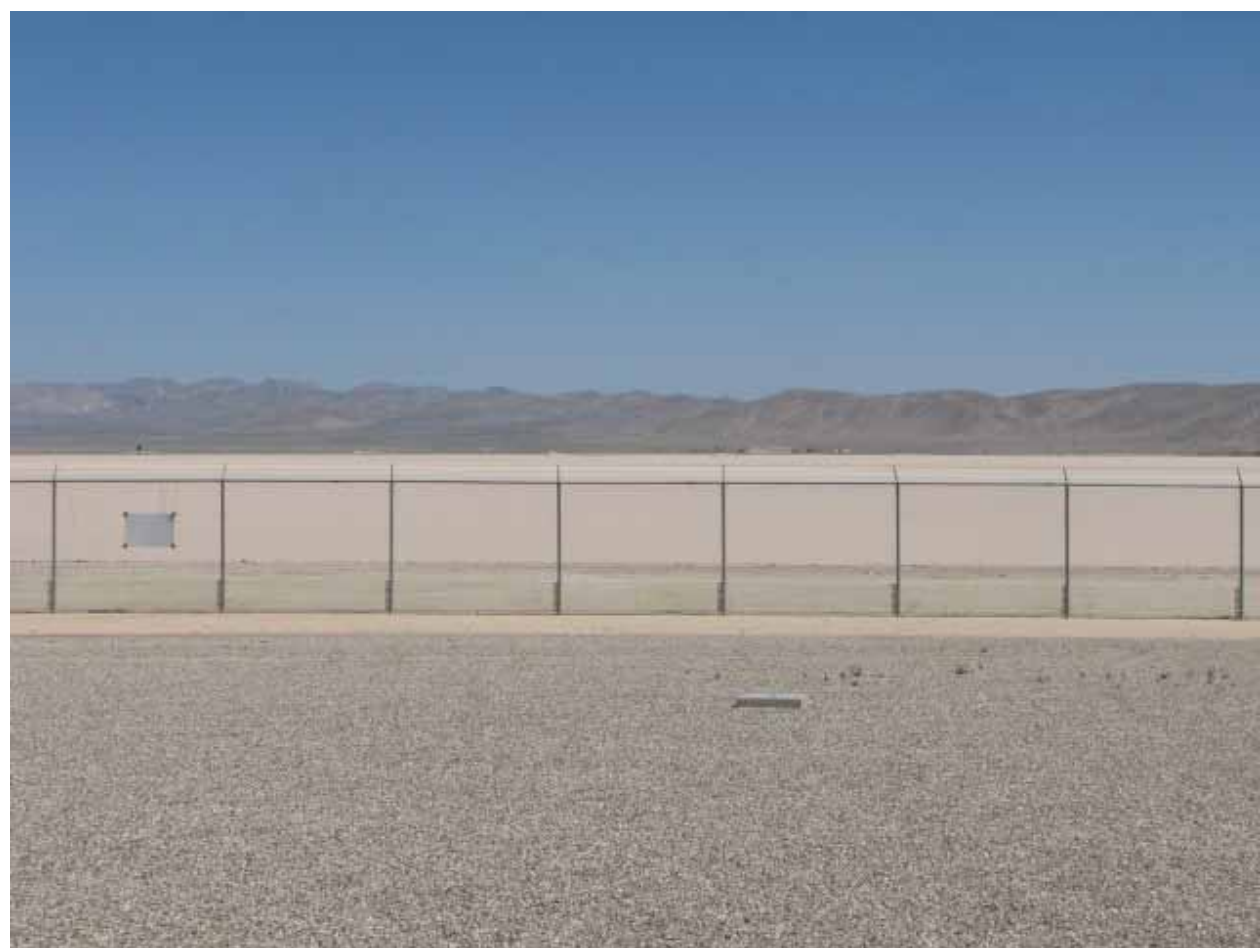

Photograph 57: CAU 92, Inside Facing North, 09/08/2010

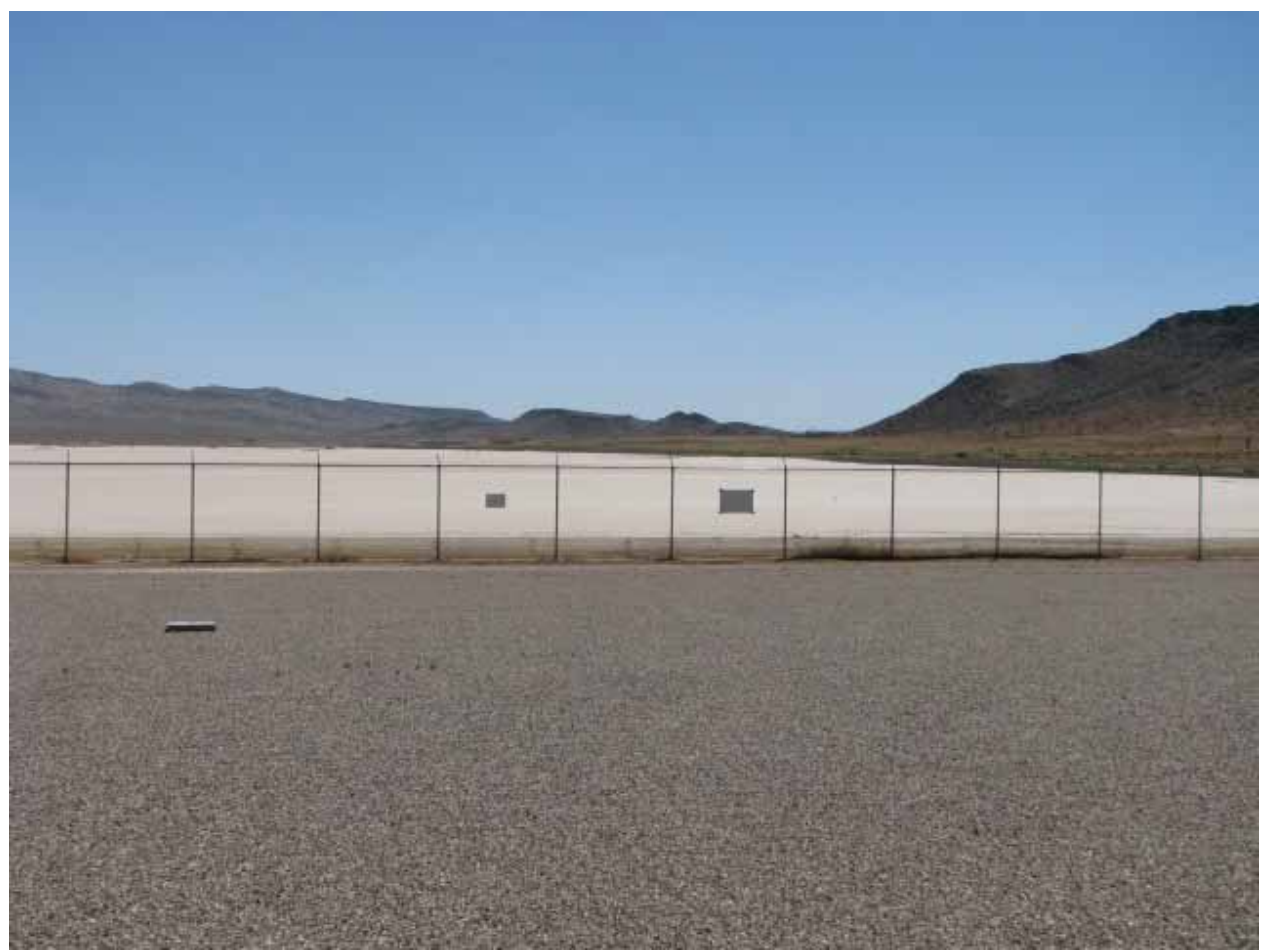

Photograph 58: CAU 92, Inside Facing East, 09/08/2010 


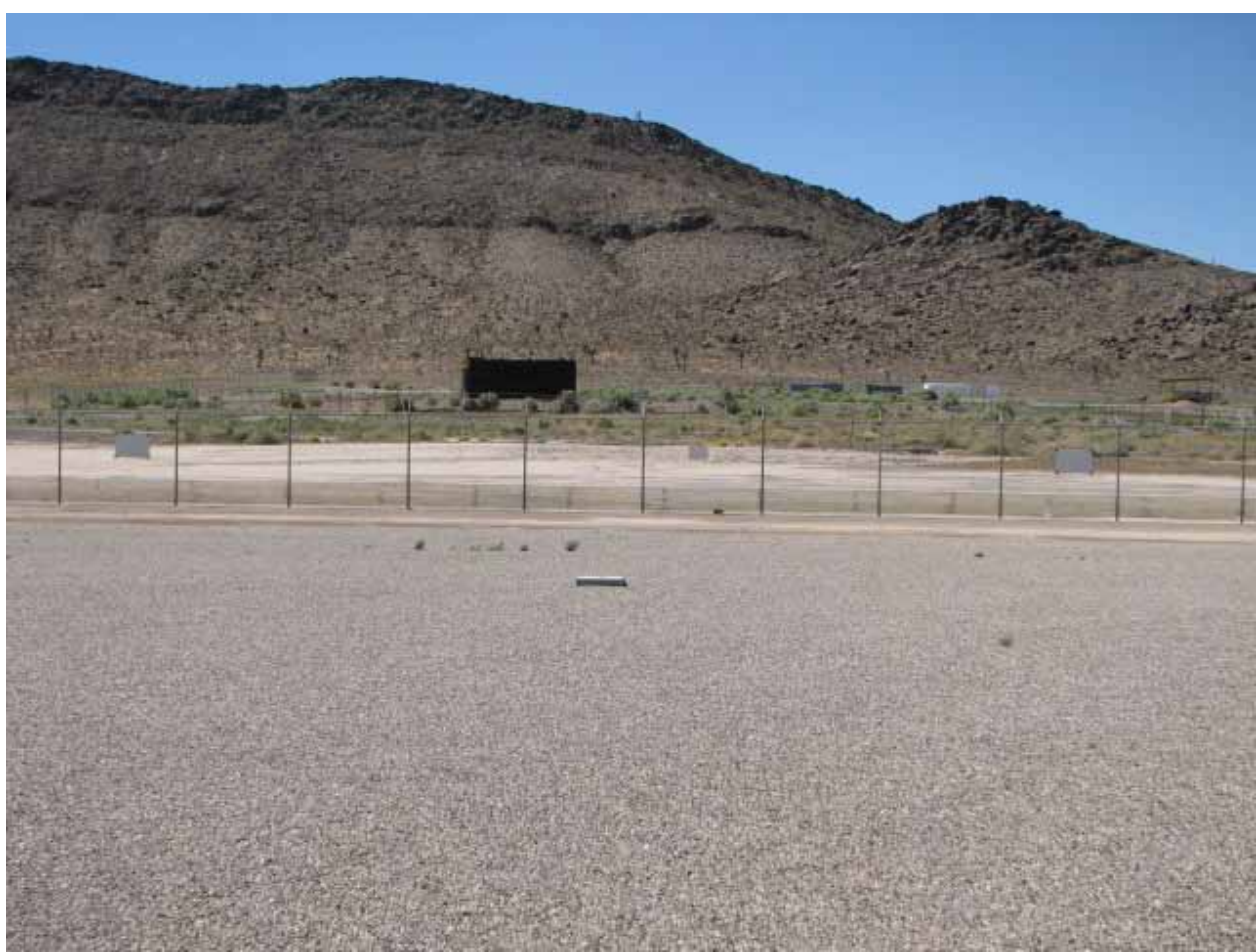

Photograph 59: CAU 92, Inside Facing South, 09/08/2010

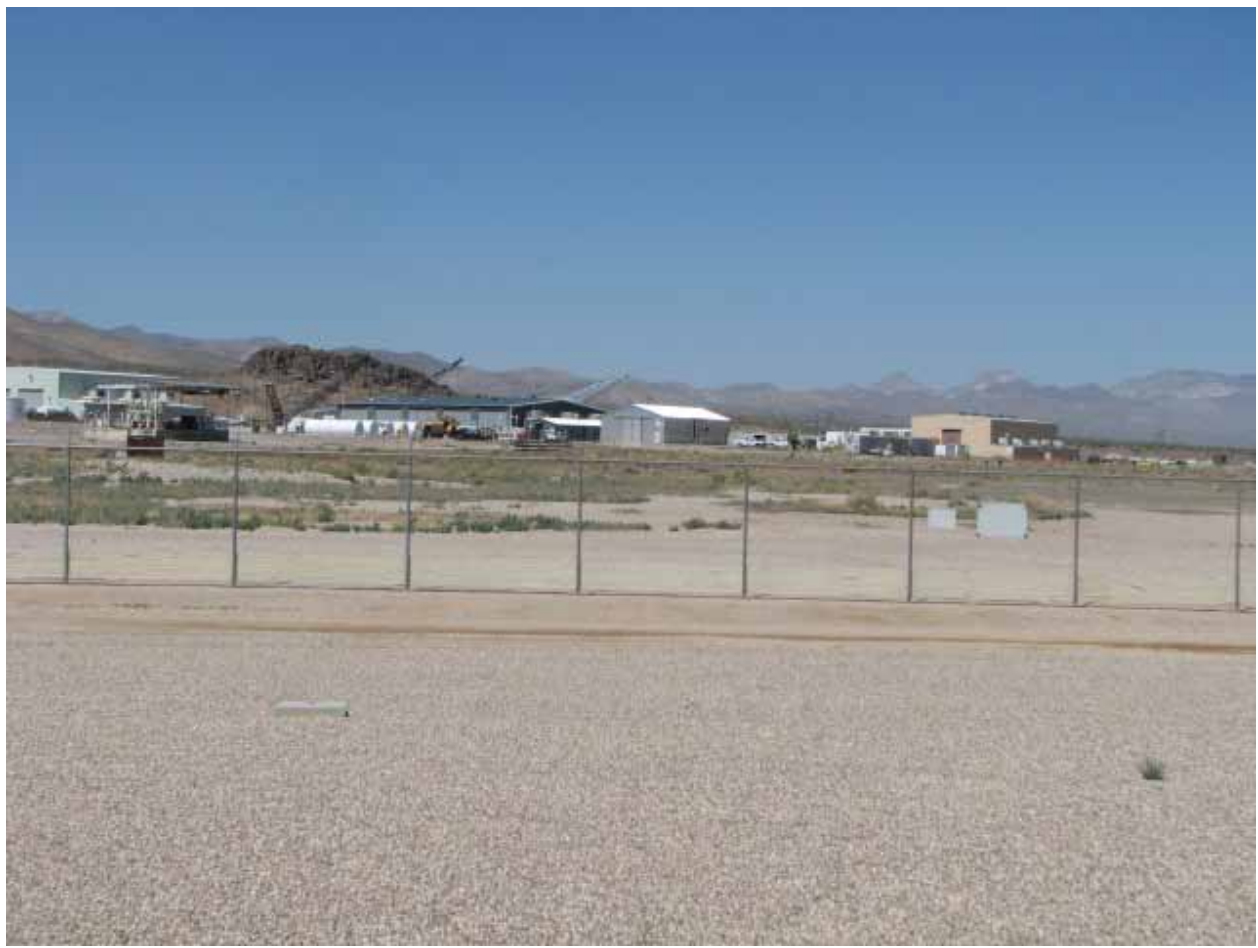

Photograph 60: CAU 92, Inside Facing West, 09/08/2010 


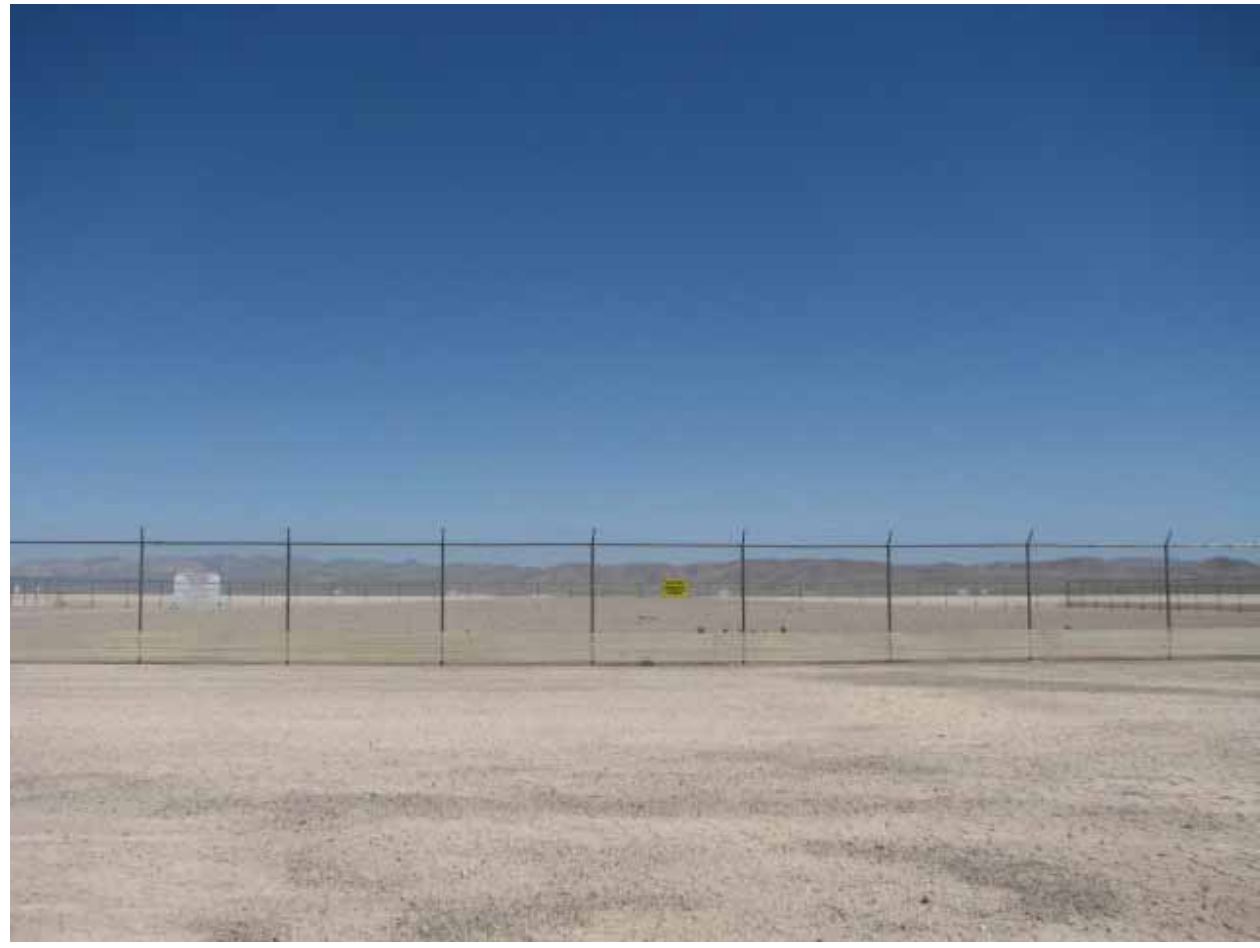

Photograph 61: CAU 92, Outside Facing North, 09/08/2010

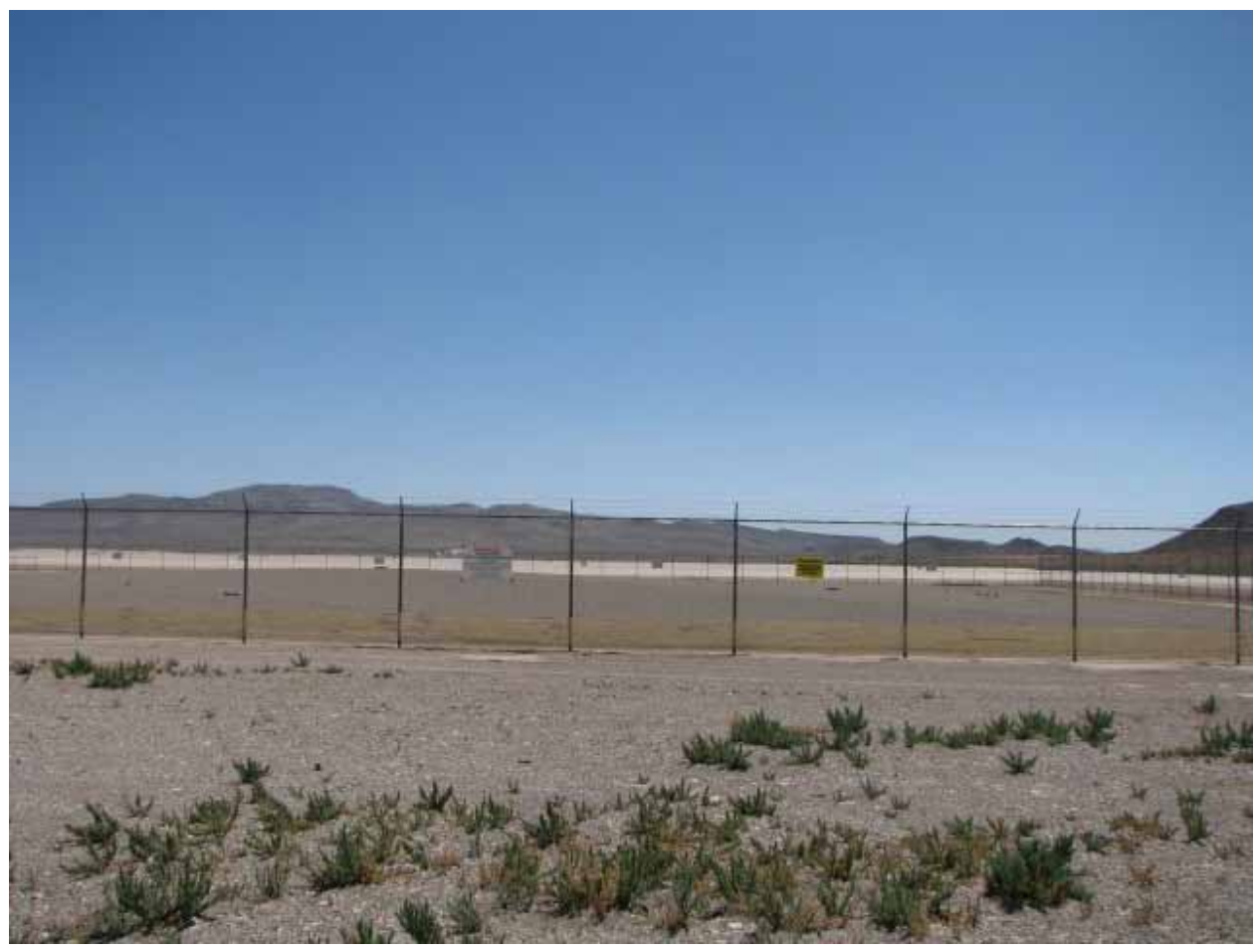

Photograph 62: CAU 92, Outside Facing East, 09/08/2010 


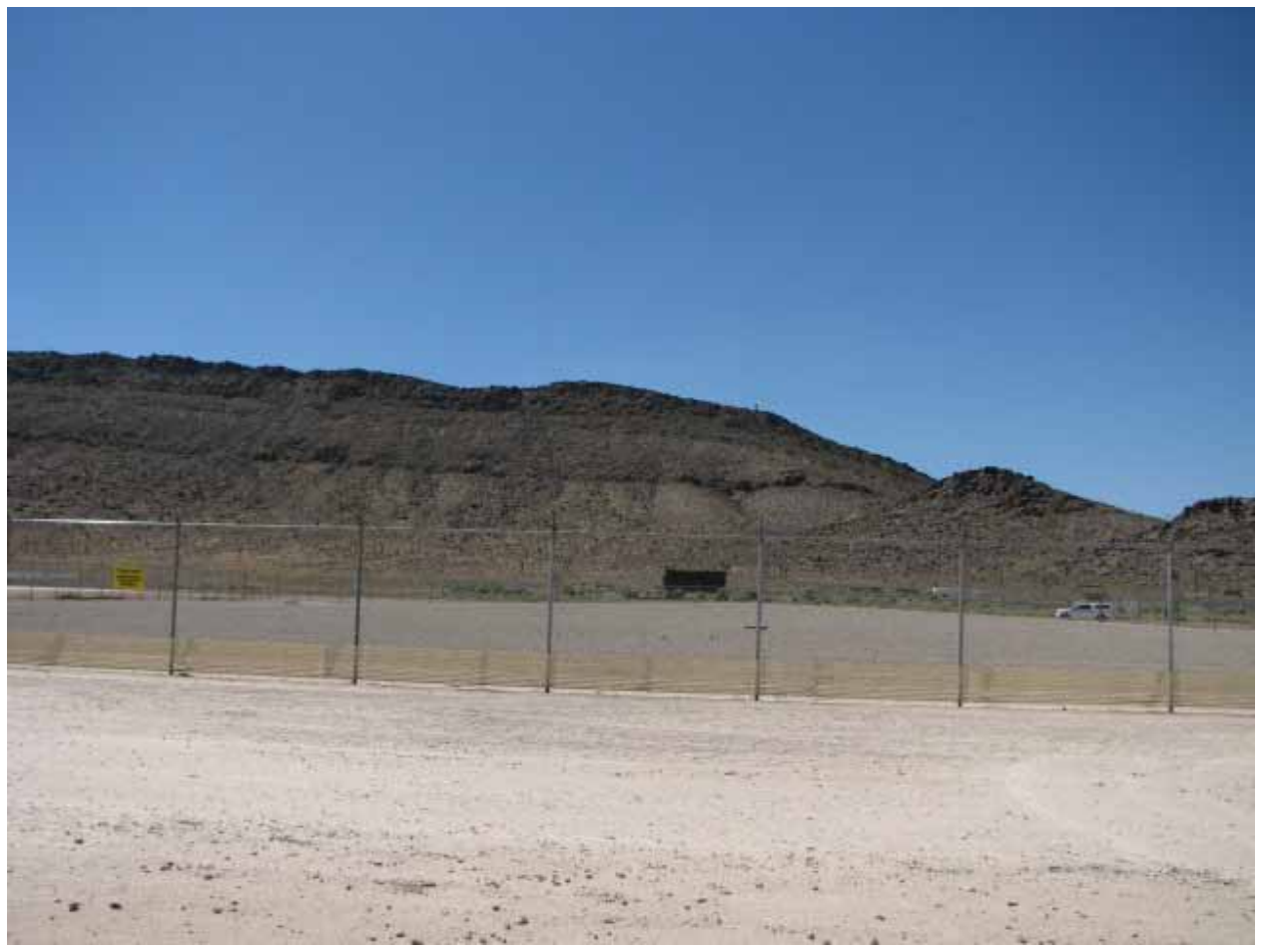

Photograph 63: CAU 92, Outside Facing South, 09/08/2010

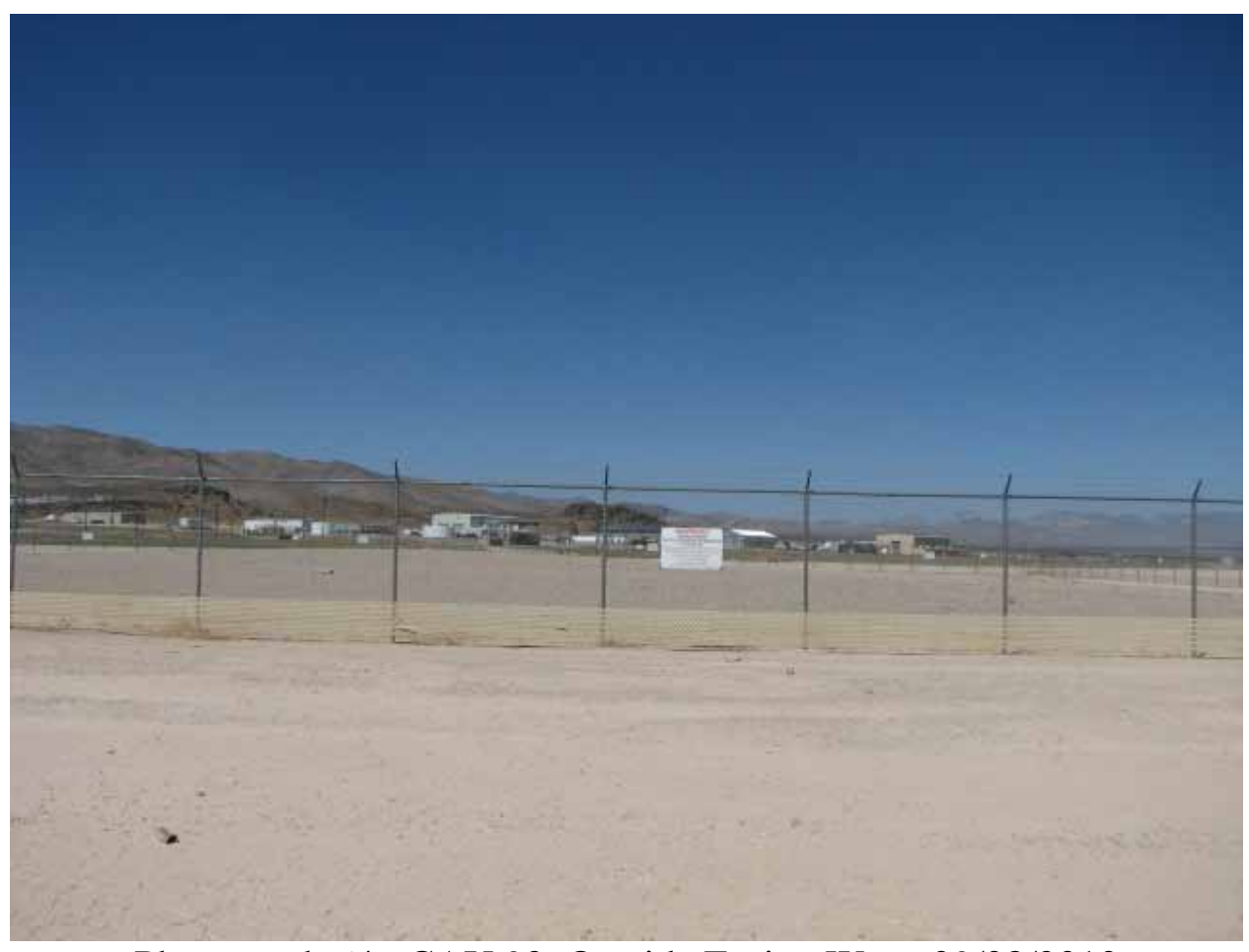

Photograph 64: CAU 92, Outside Facing West, 09/08/2010 


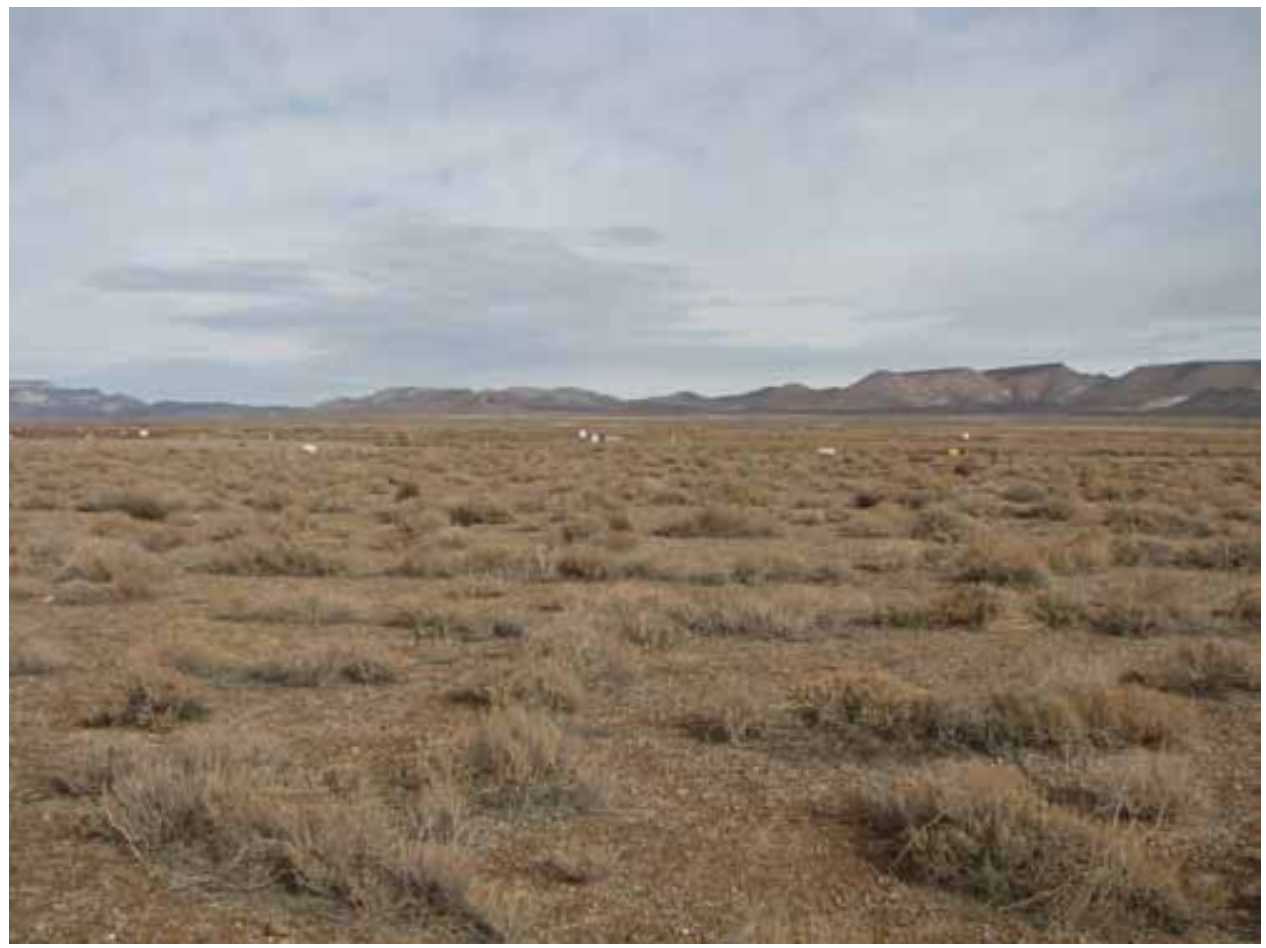

Photograph 65: CAU 110, Inside Facing North, 12/15/2009

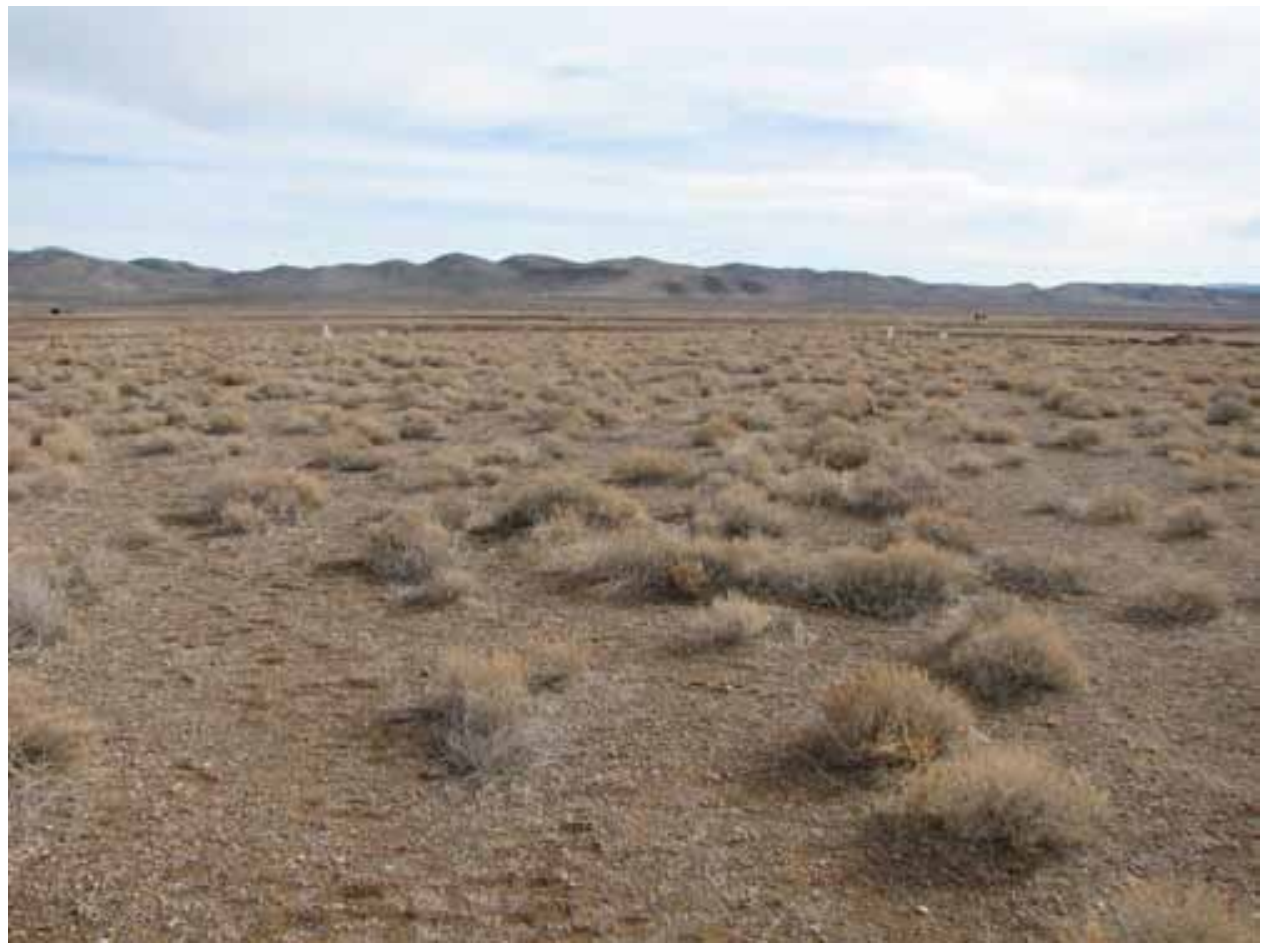

Photograph 66: CAU 110, Inside Facing East, 12/15/2009 


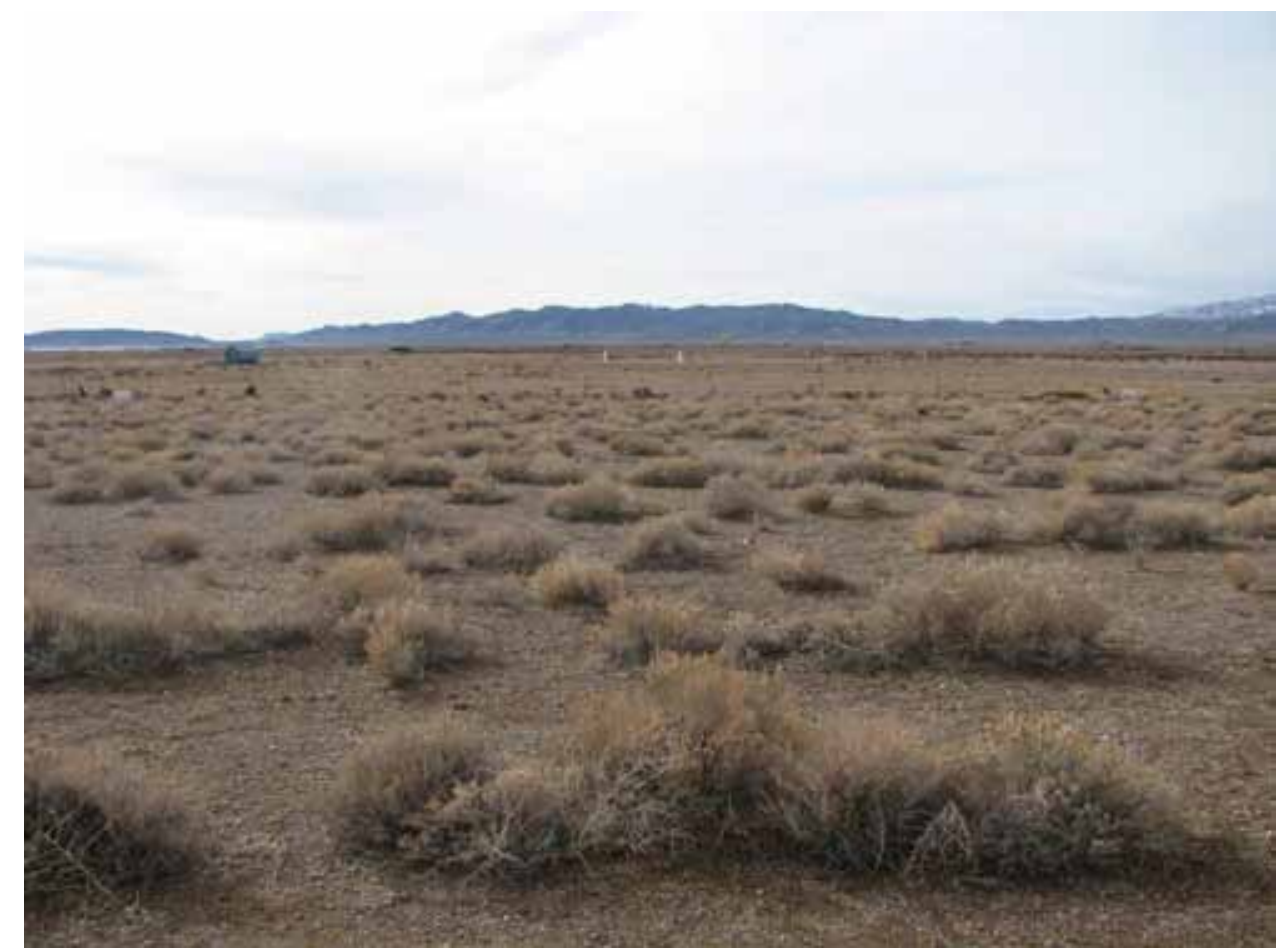

Photograph 67: CAU 110, Inside Facing South, 12/15/2009

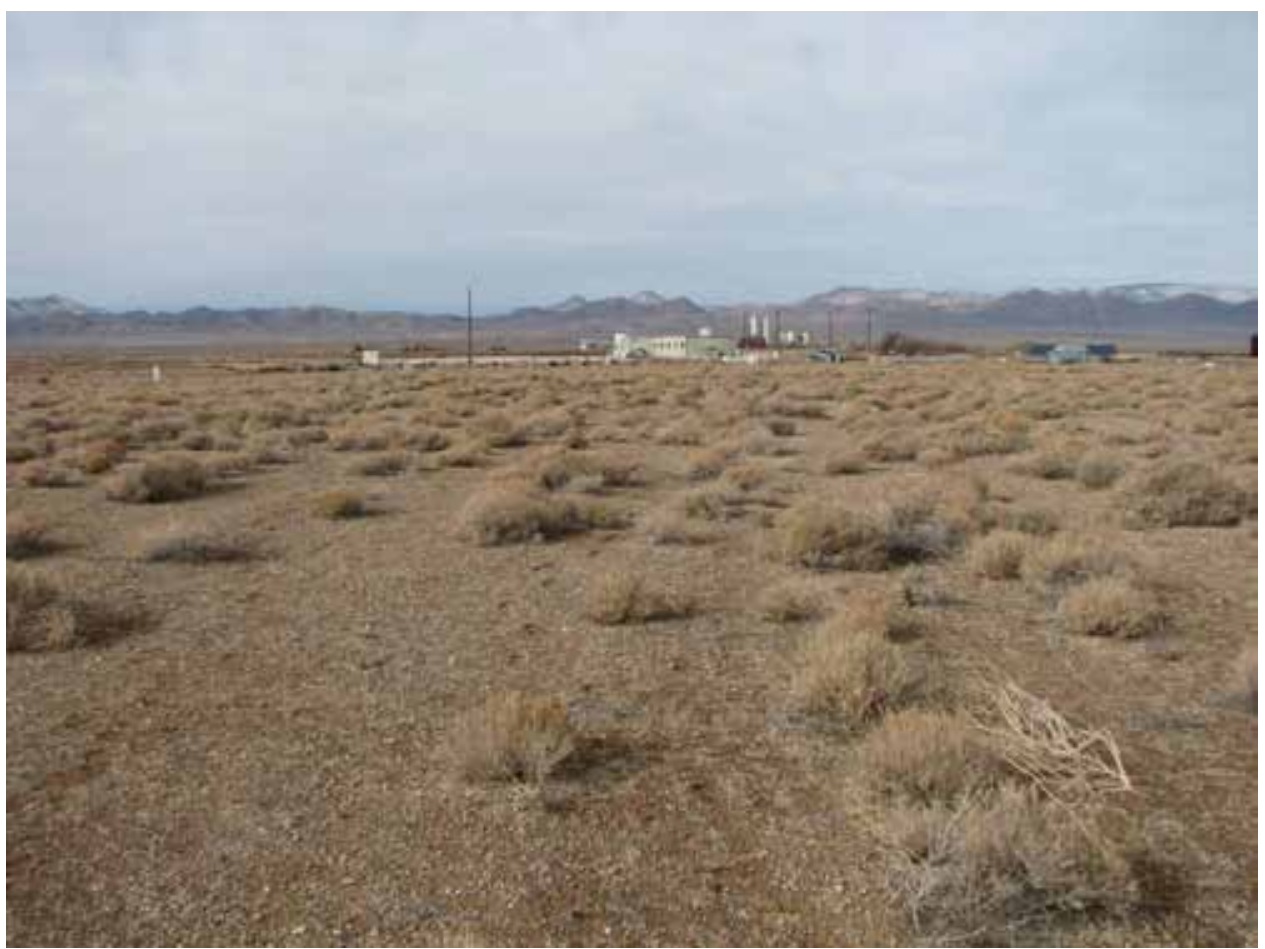

Photograph 68: CAU 110, Inside Facing West, 12/15/2009 


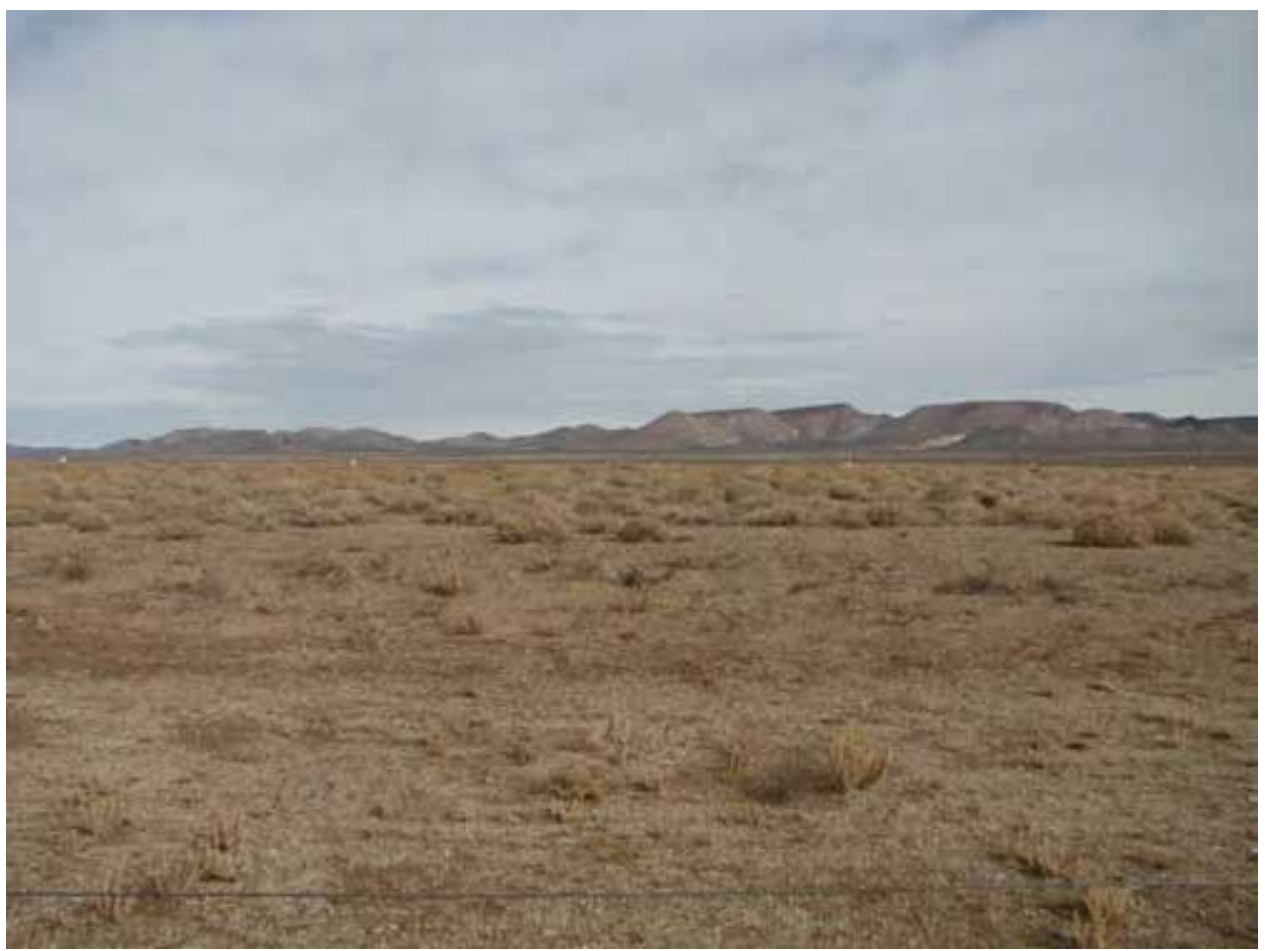

Photograph 69: CAU 110, Outside Facing North, 12/15/2009

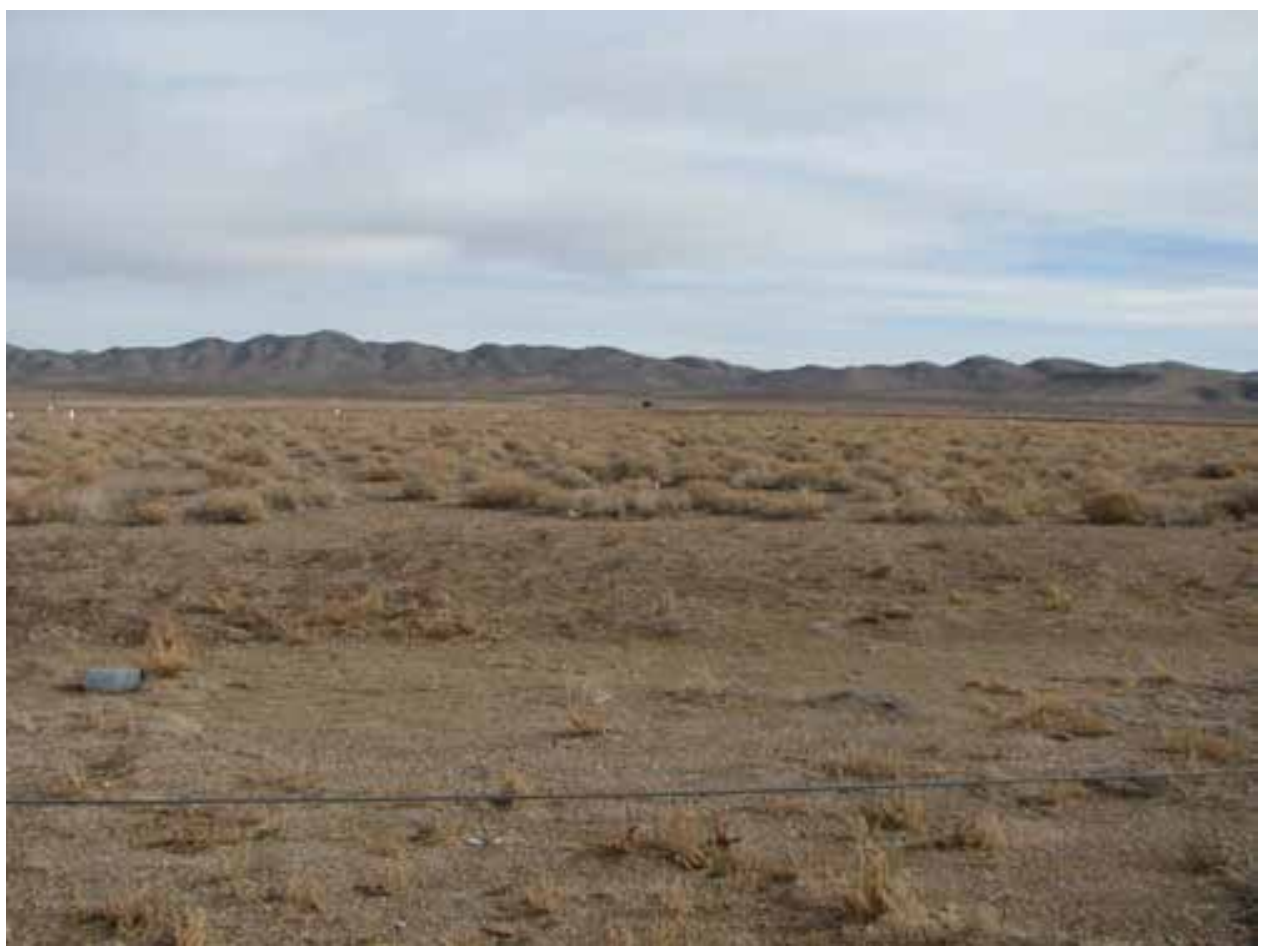

Photograph 70: CAU 110, Outside Facing East, 12/15/2009 


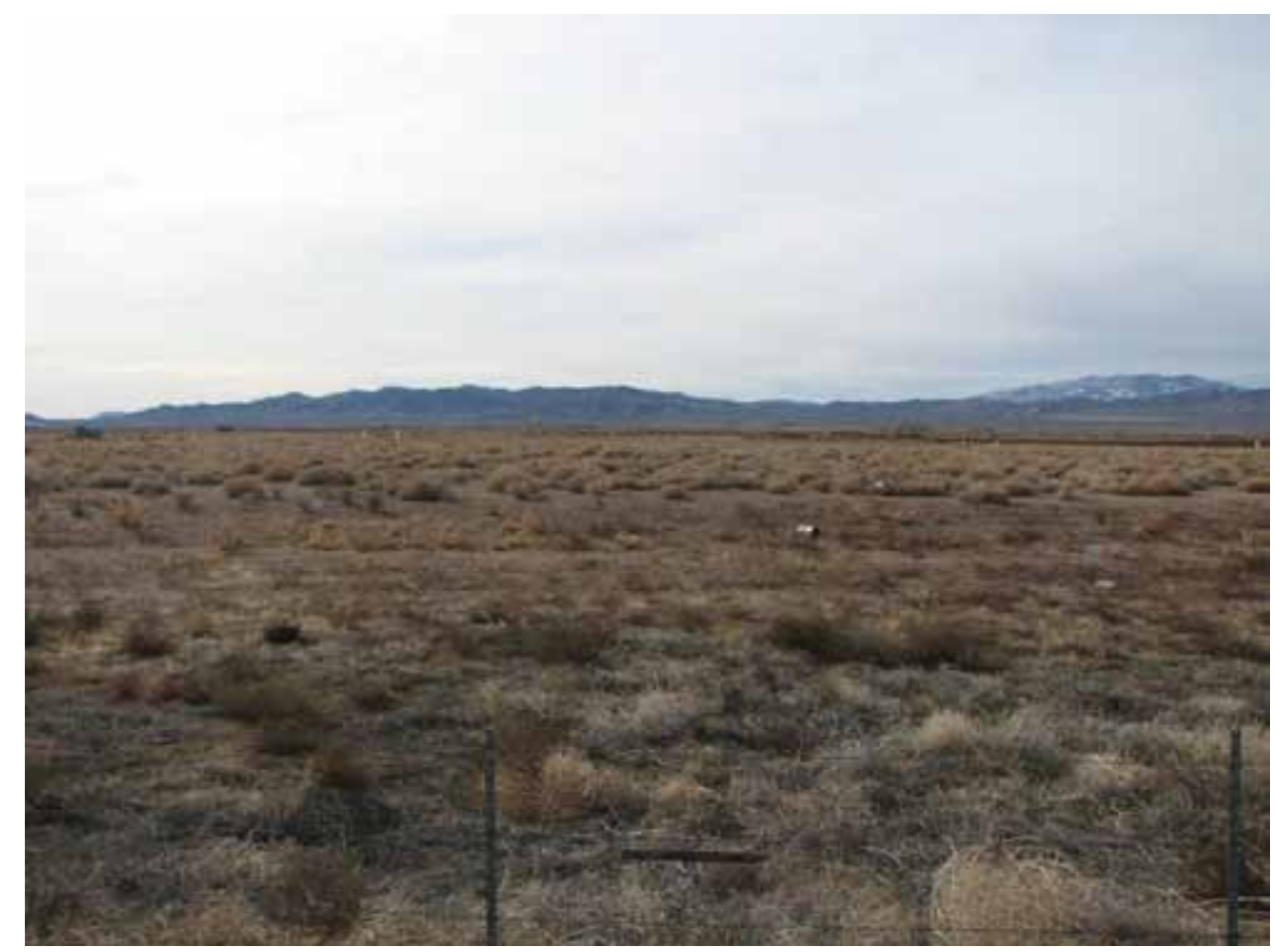

Photograph 71: CAU 110, Outside Facing South, 12/15/2009

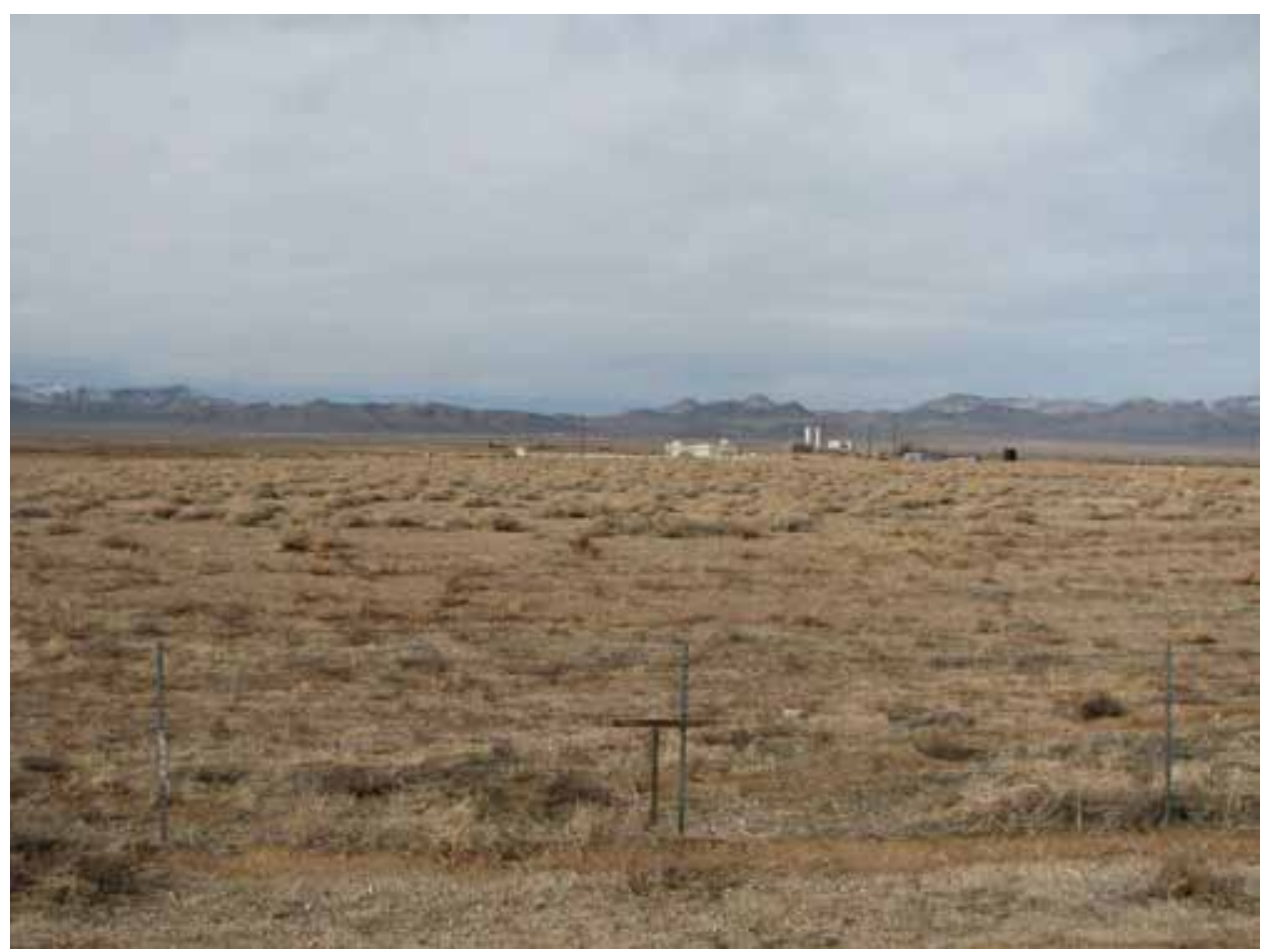

Photograph 72: CAU 110, Outside Facing West, 12/15/2009 


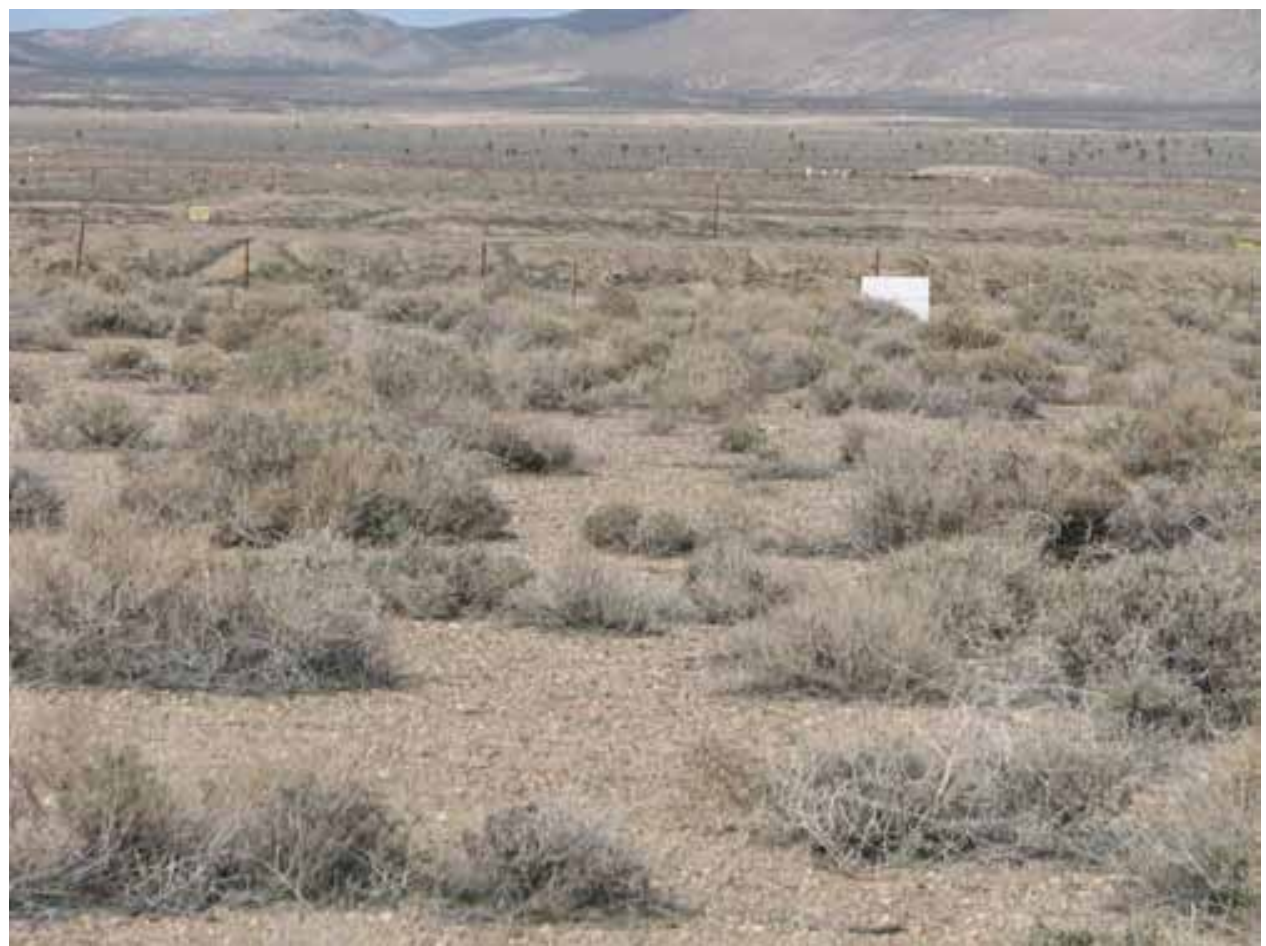

Photograph 73: CAU 110, Inside Facing North, 03/17/2010

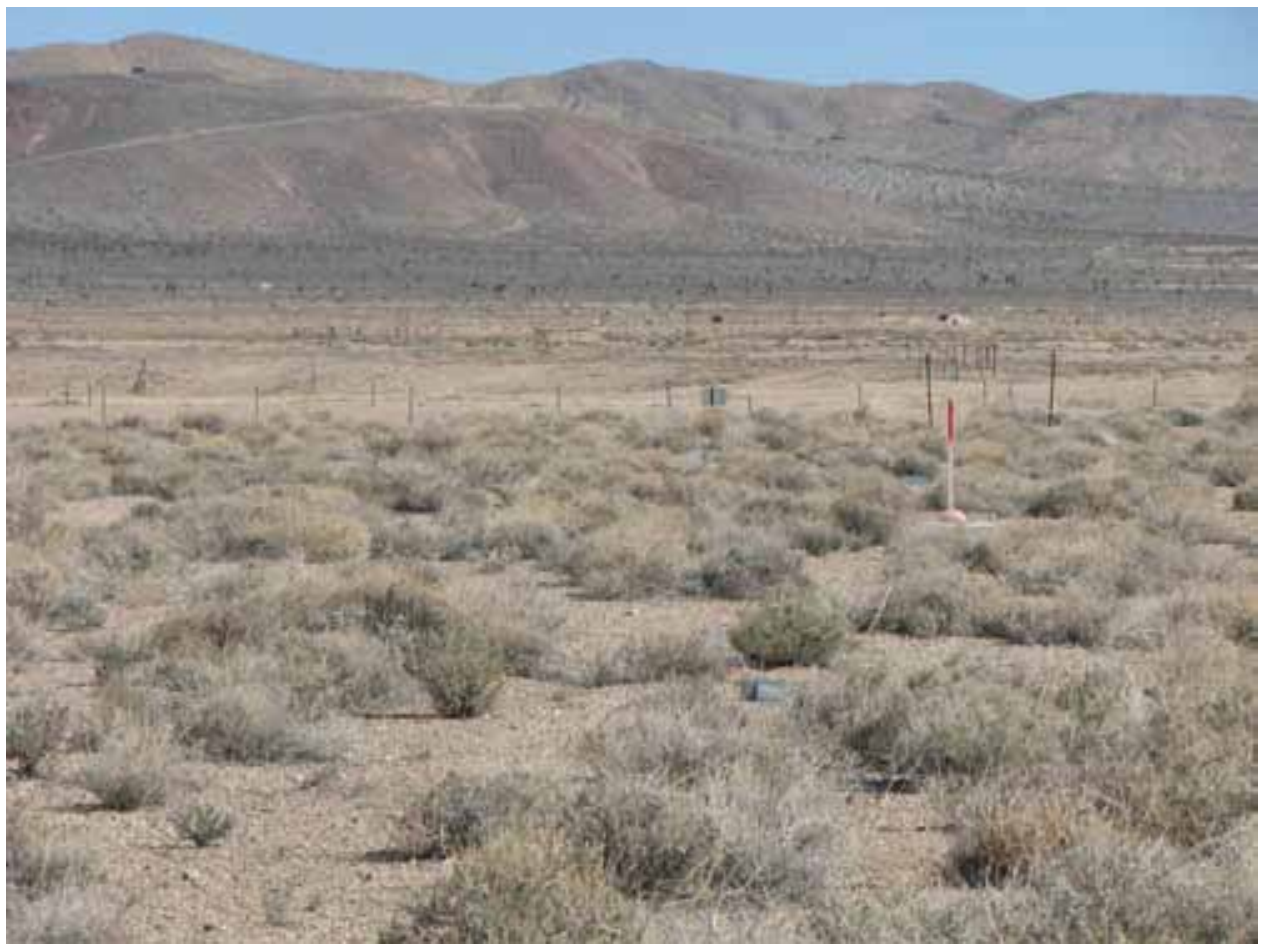

Photograph 74: CAU 110, Inside Facing East, 03/17/2010 


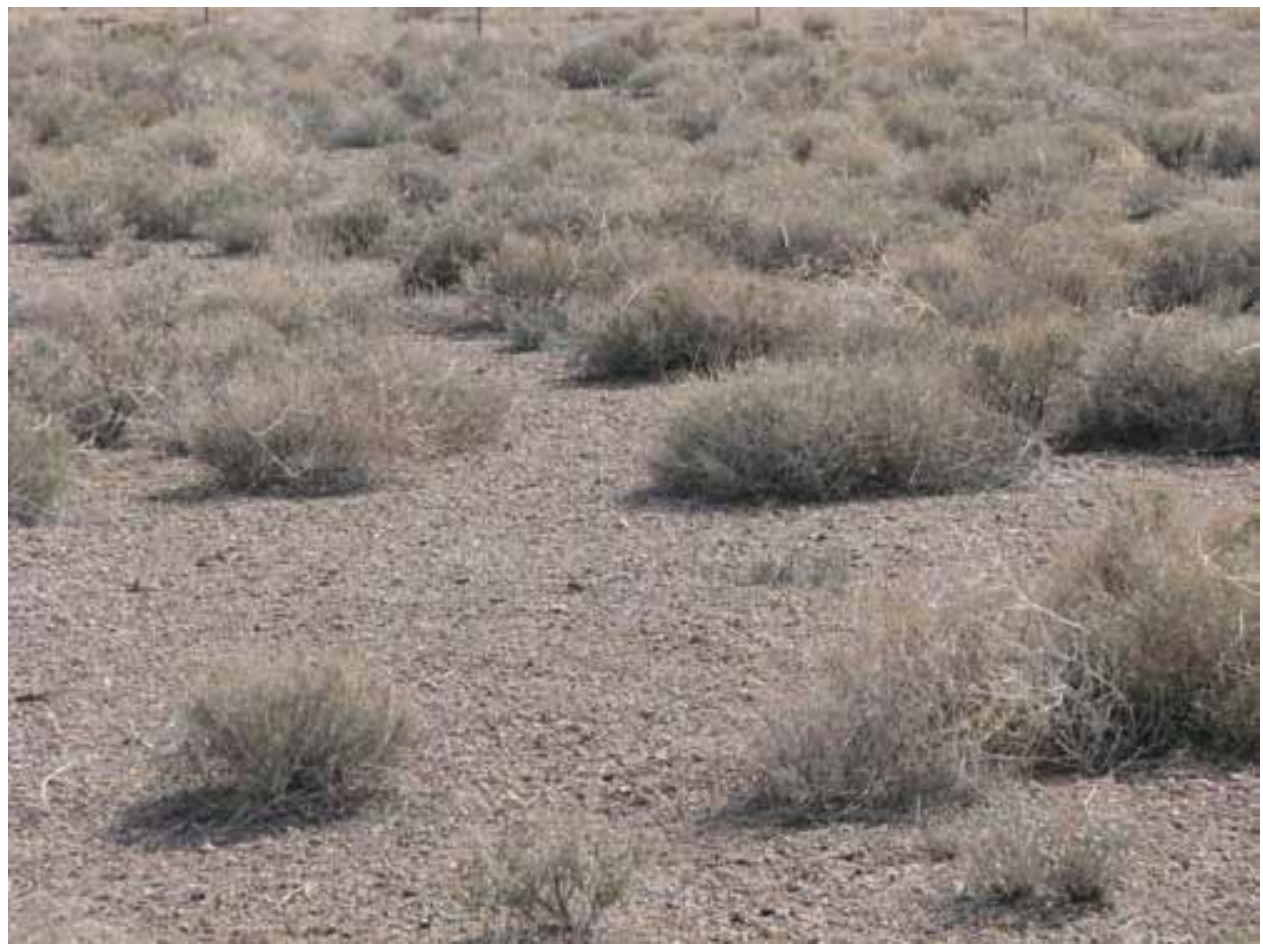

Photograph 75: CAU 110, Inside Facing South, 03/17/2010

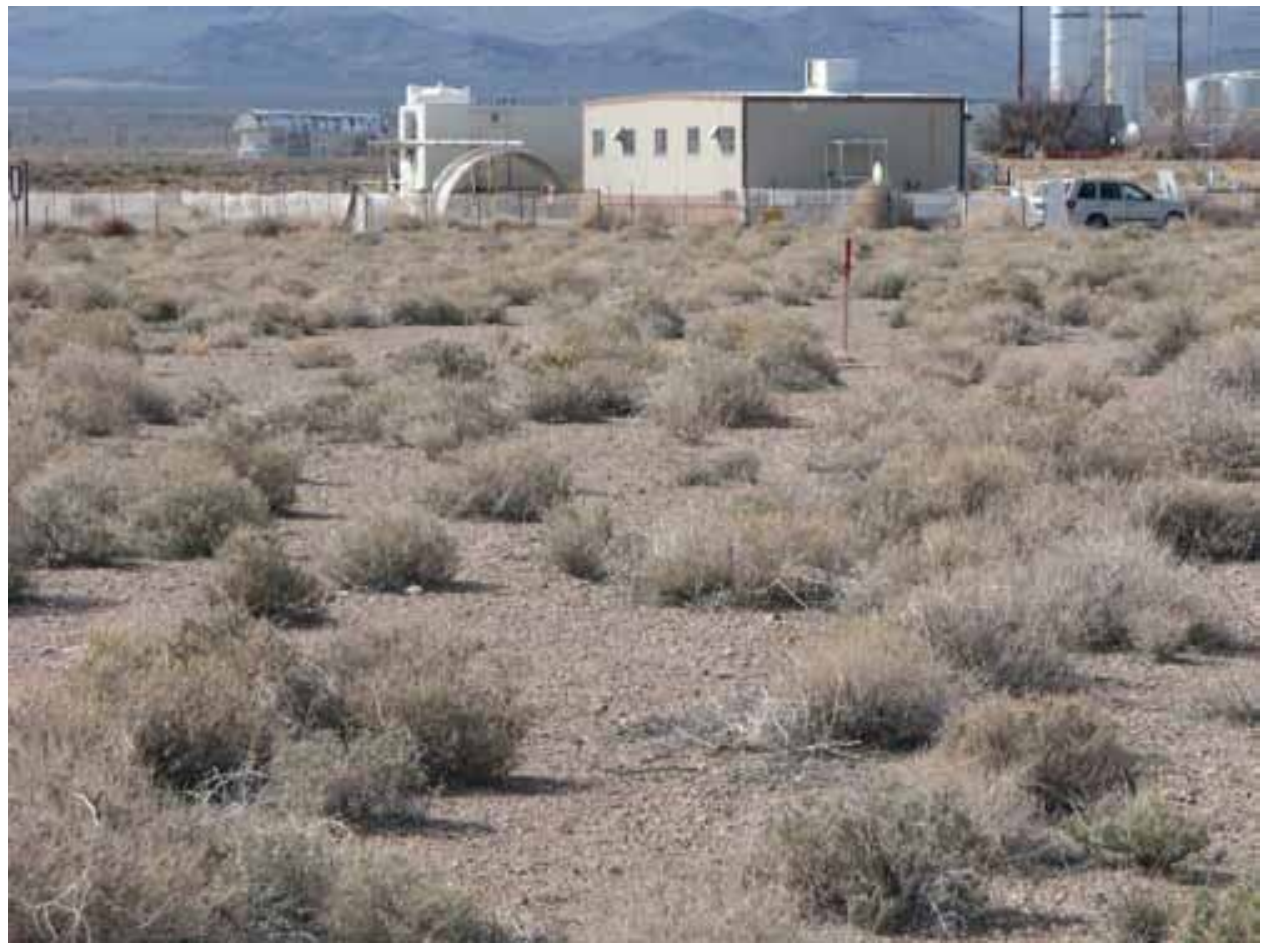

Photograph 76: CAU 110, Inside Facing West, 03/17/2010 


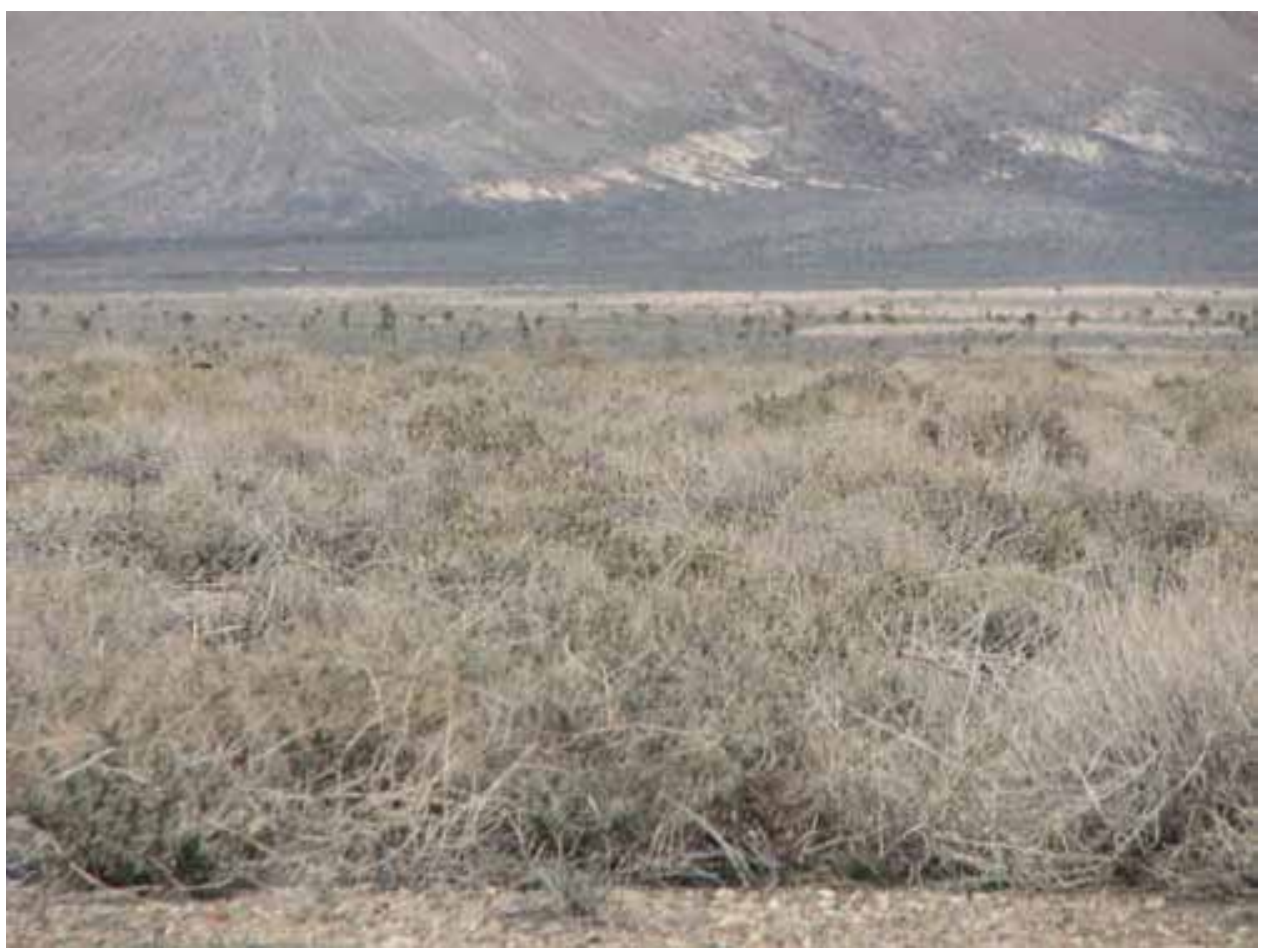

Photograph 77: CAU 110, Outside Facing North, 03/17/2010

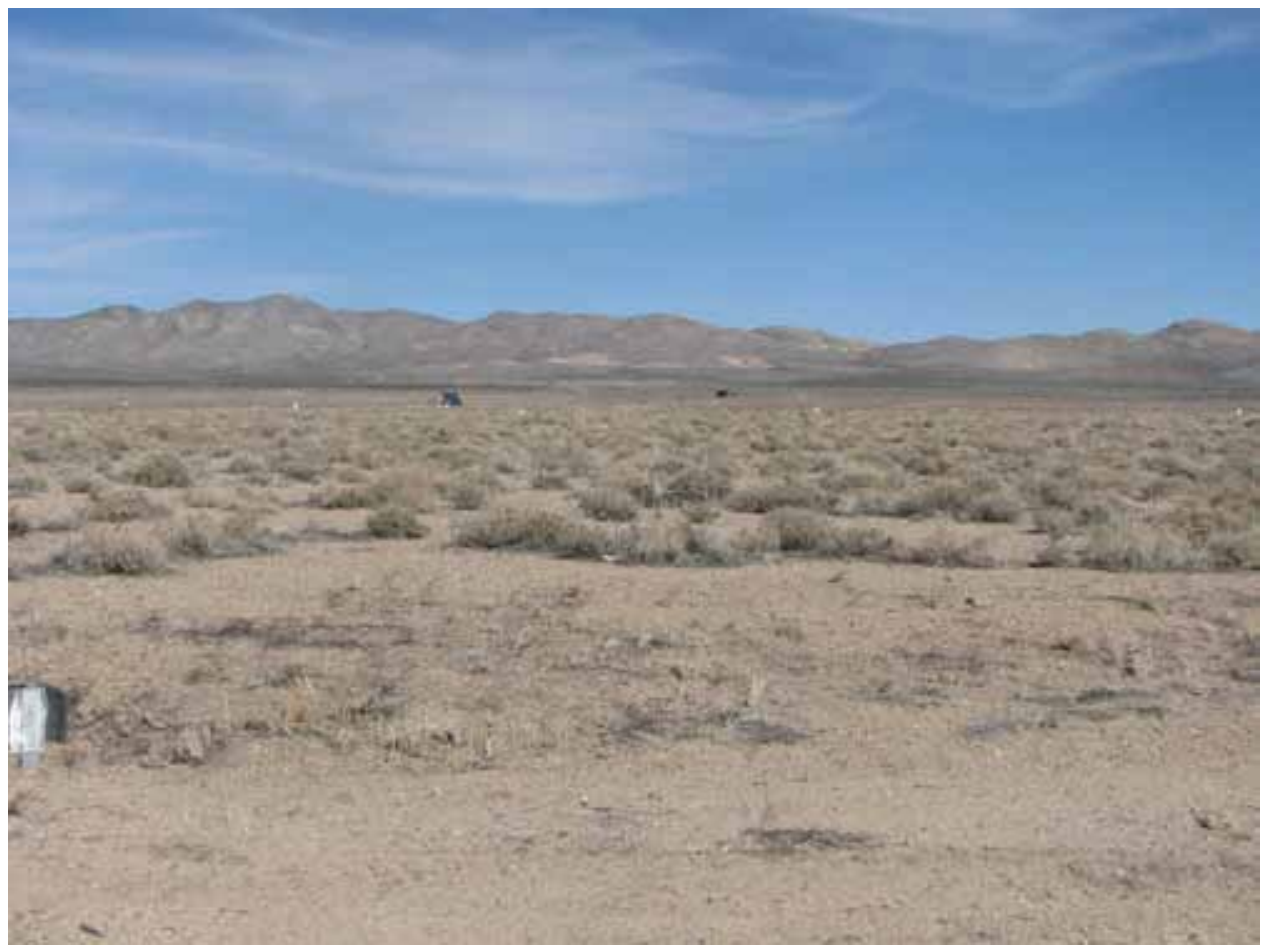

Photograph 78: CAU 110, Outside Facing East, 03/17/2010 


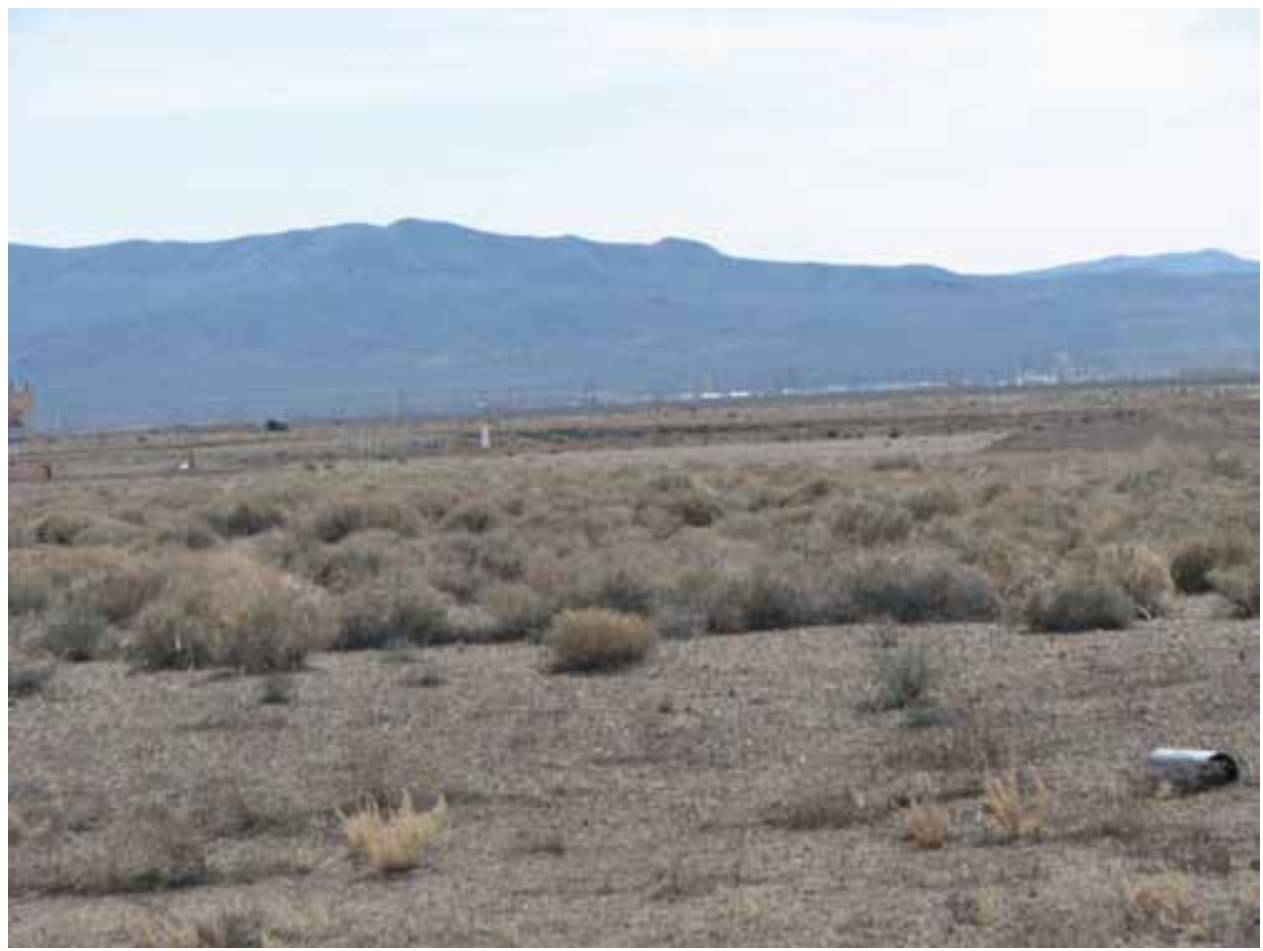

Photograph 79: CAU 110, Outside Facing South, 03/17/2010

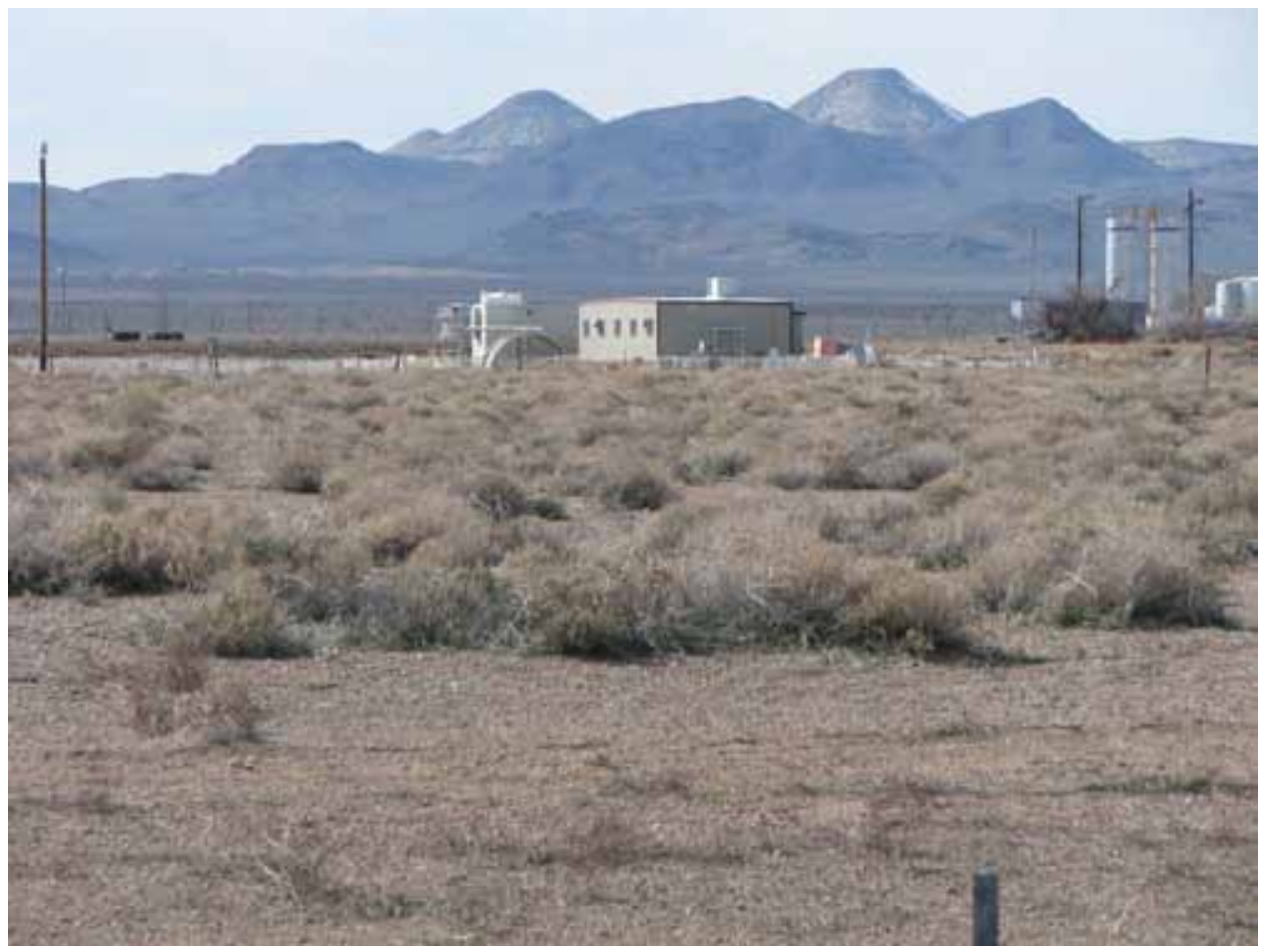

Photograph 80: CAU 110, Outside Facing West, 03/17/2010 


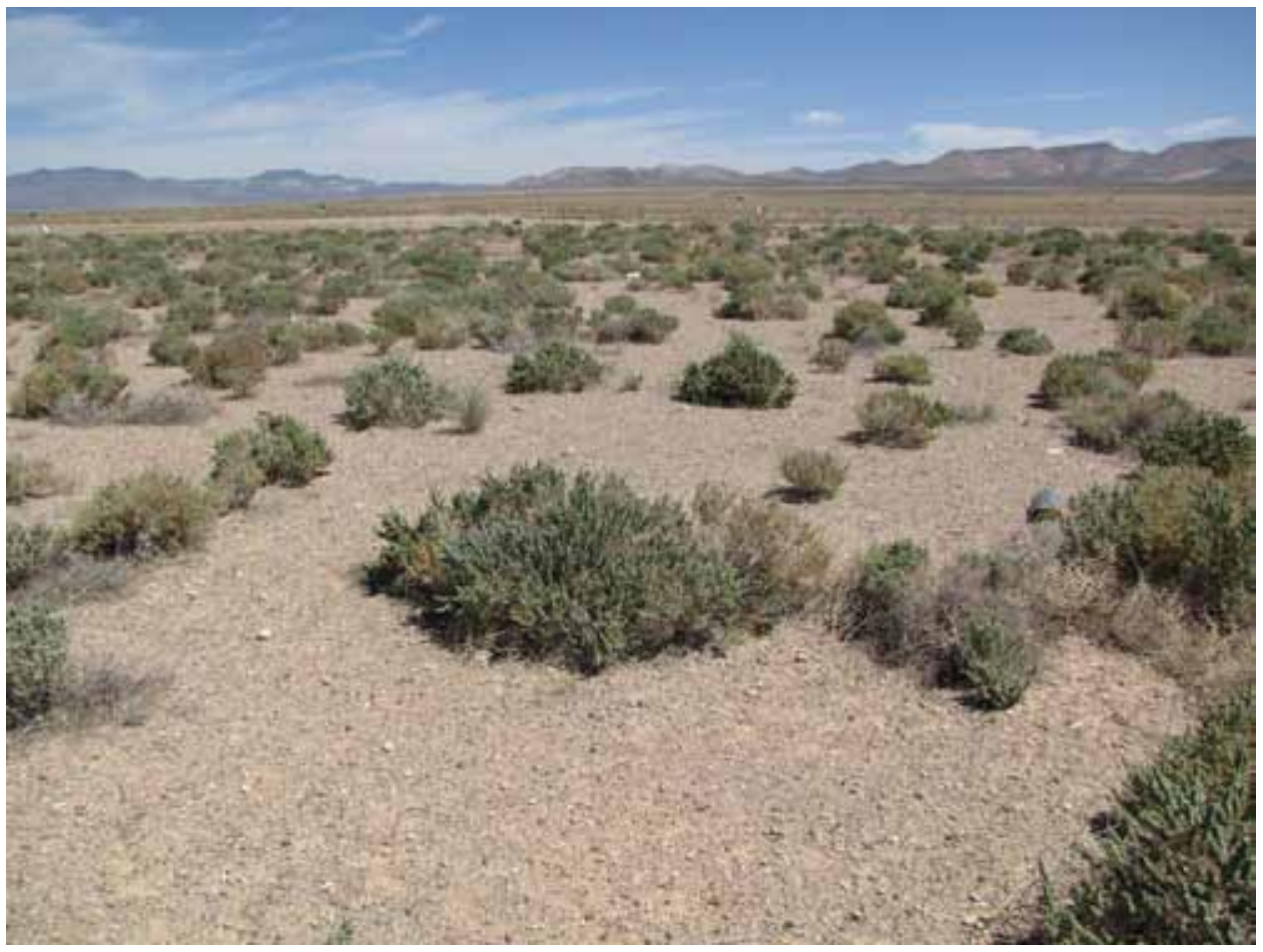

Photograph 81: CAU 110, Inside Facing North, 06/23/2010

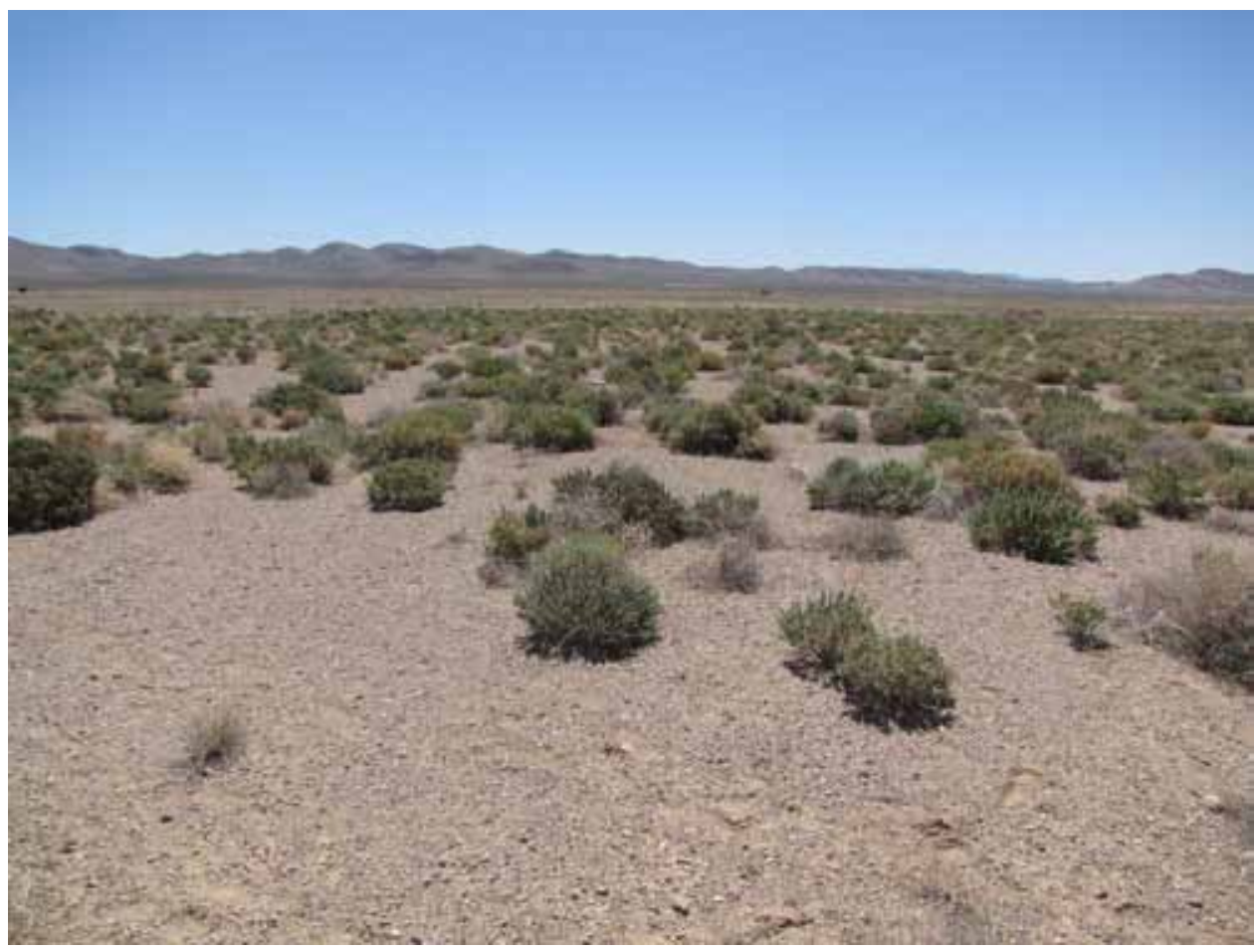

Photograph 82: CAU 110, Inside Facing East, 06/23/2010 


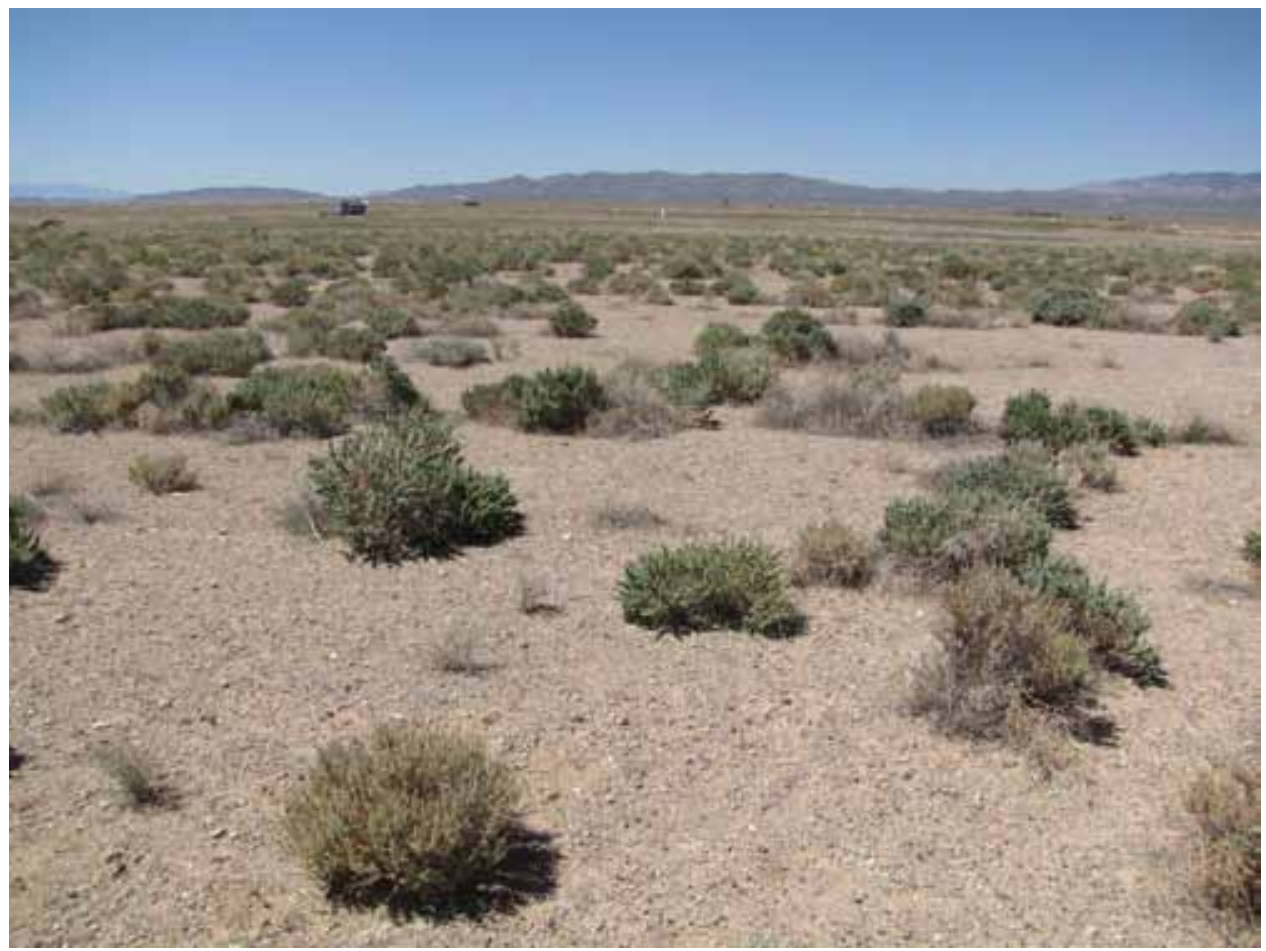

Photograph 83: CAU 110, Inside Facing South, 06/23/2010

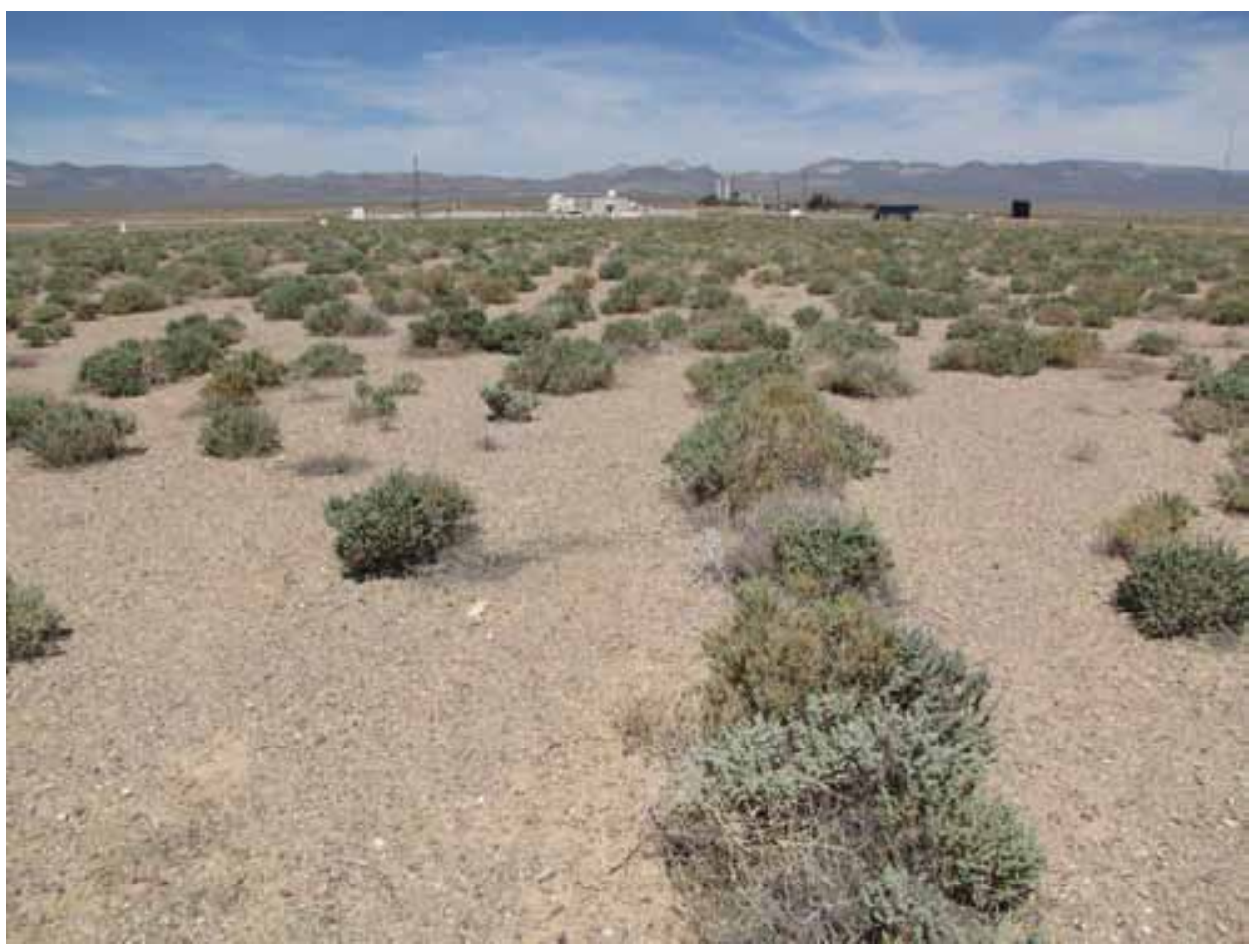

Photograph 84: CAU 110, Inside Facing West, 06/23/2010 


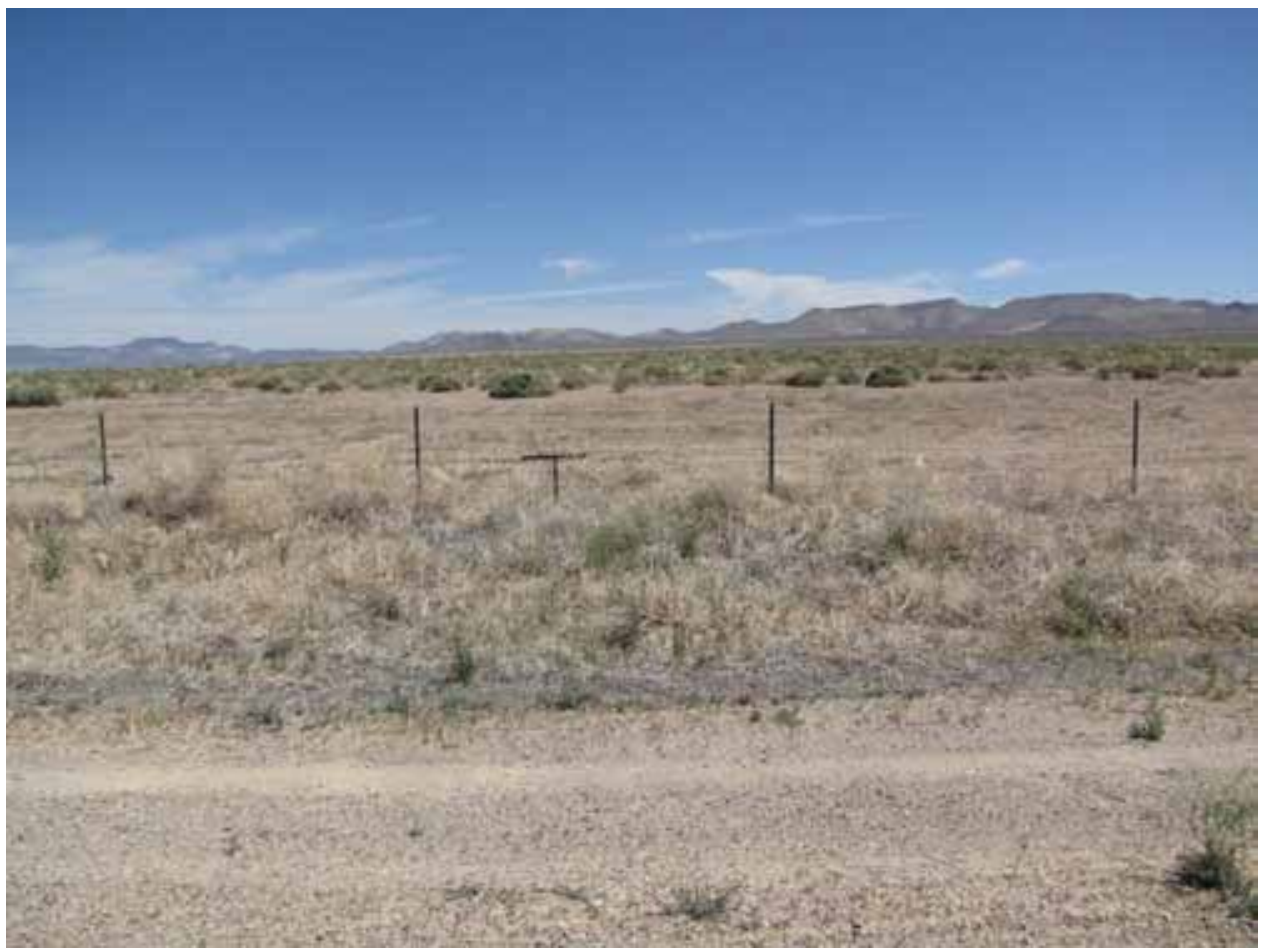

Photograph 85: CAU 110, Outside Facing North, 06/23/2010

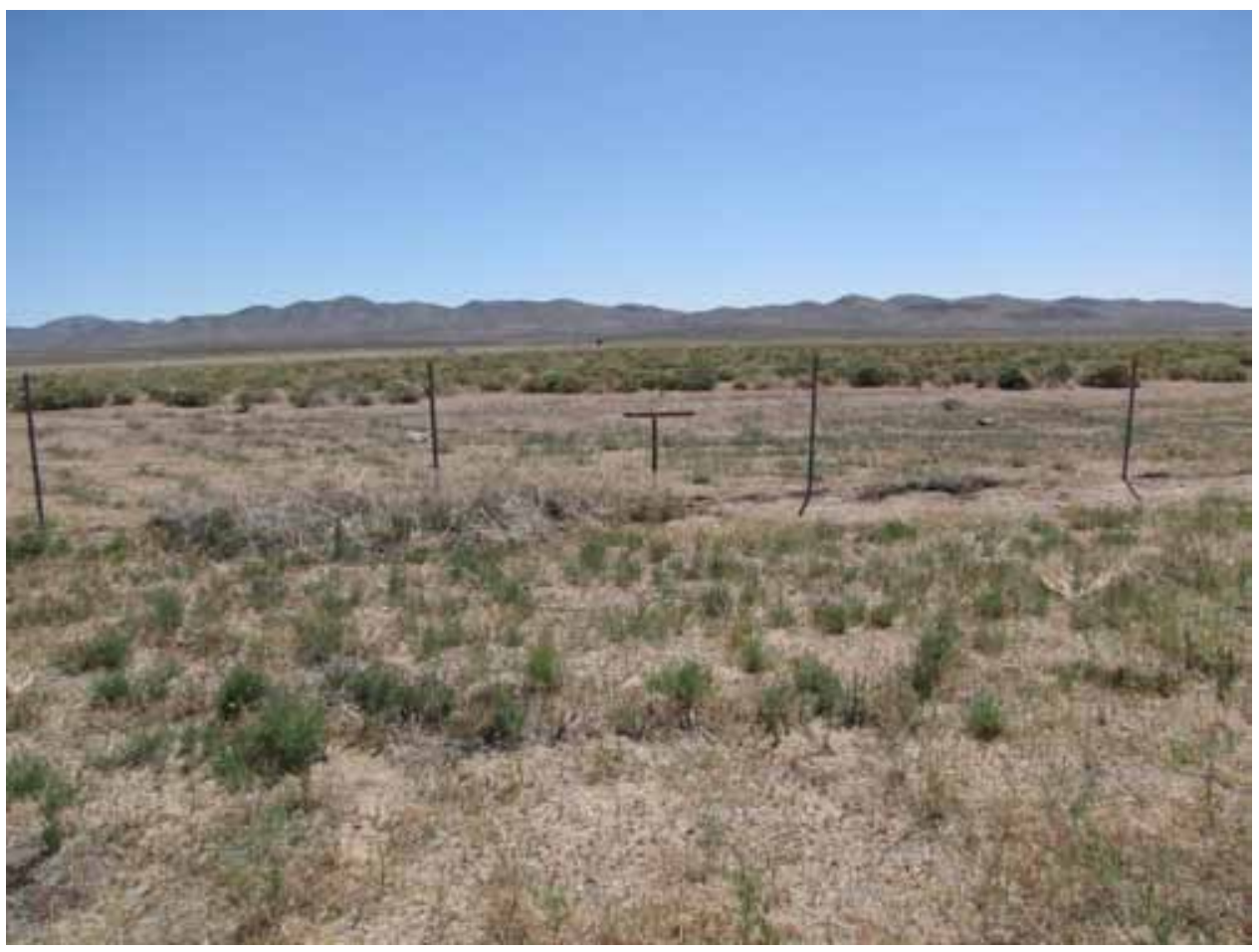

Photograph 86: CAU 110, Outside Facing East, 06/23/2010 


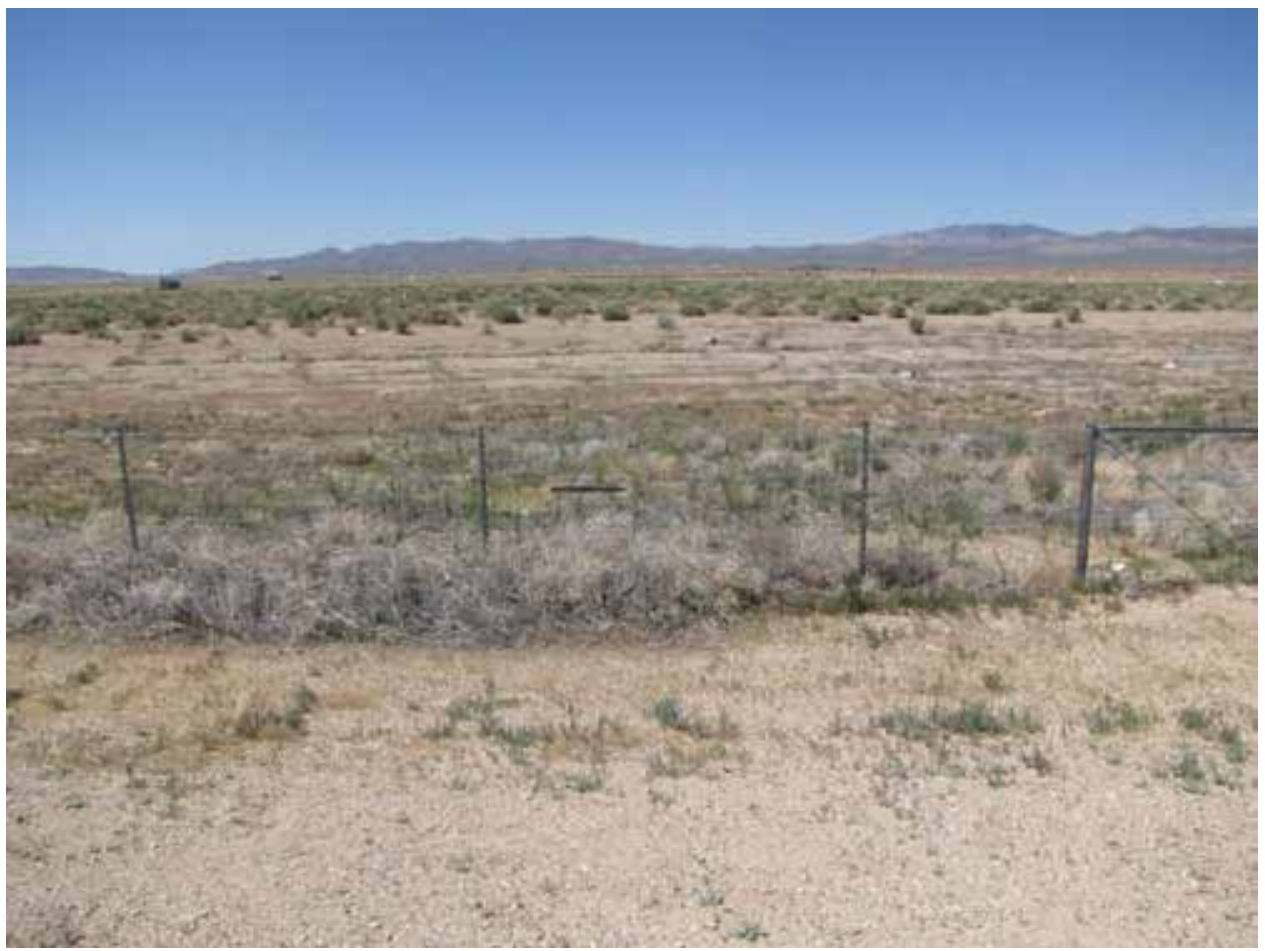

Photograph 87: CAU 110, Outside Facing South, 06/23/2010

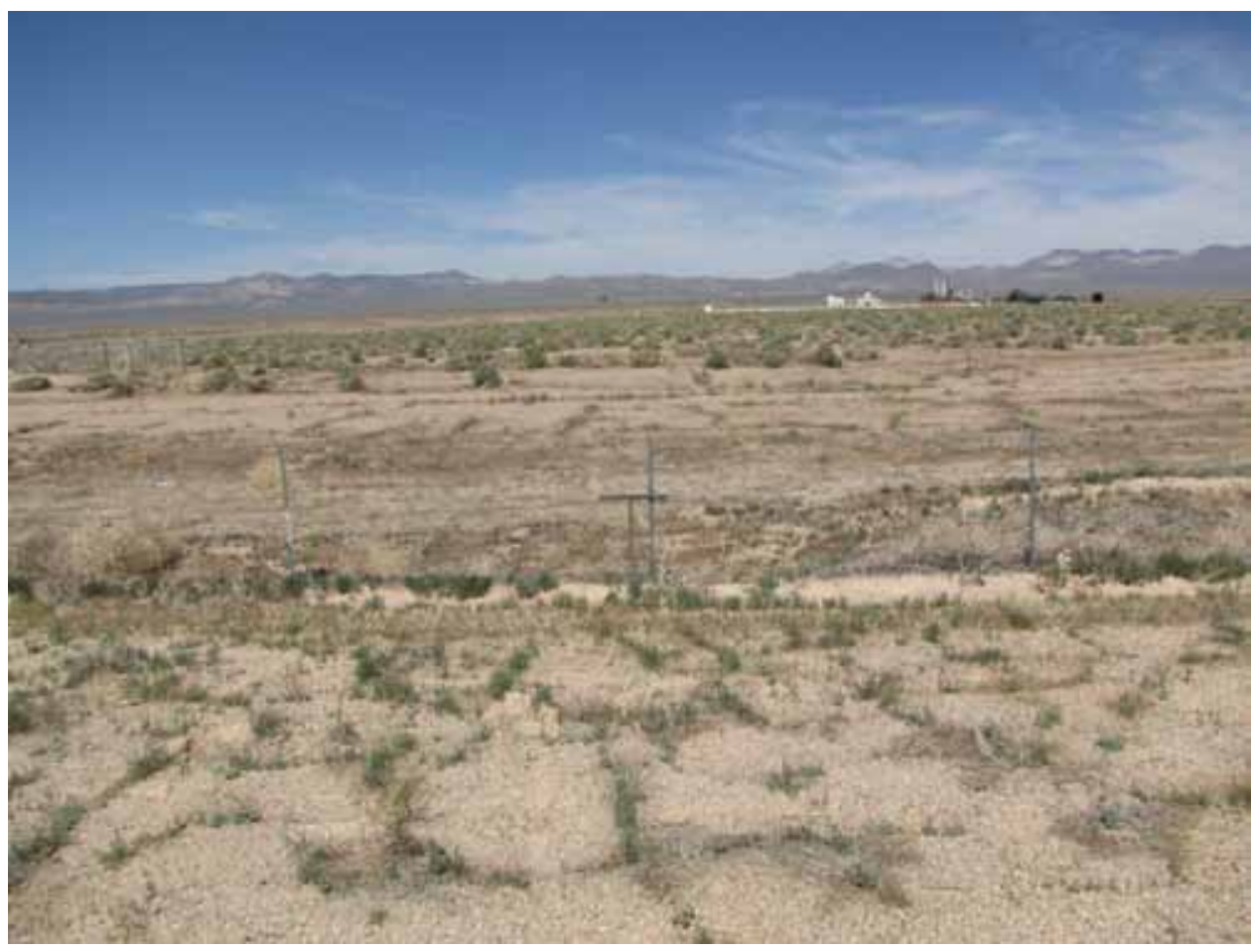

Photograph 88: CAU 110, Outside Facing West, 06/23/2010 


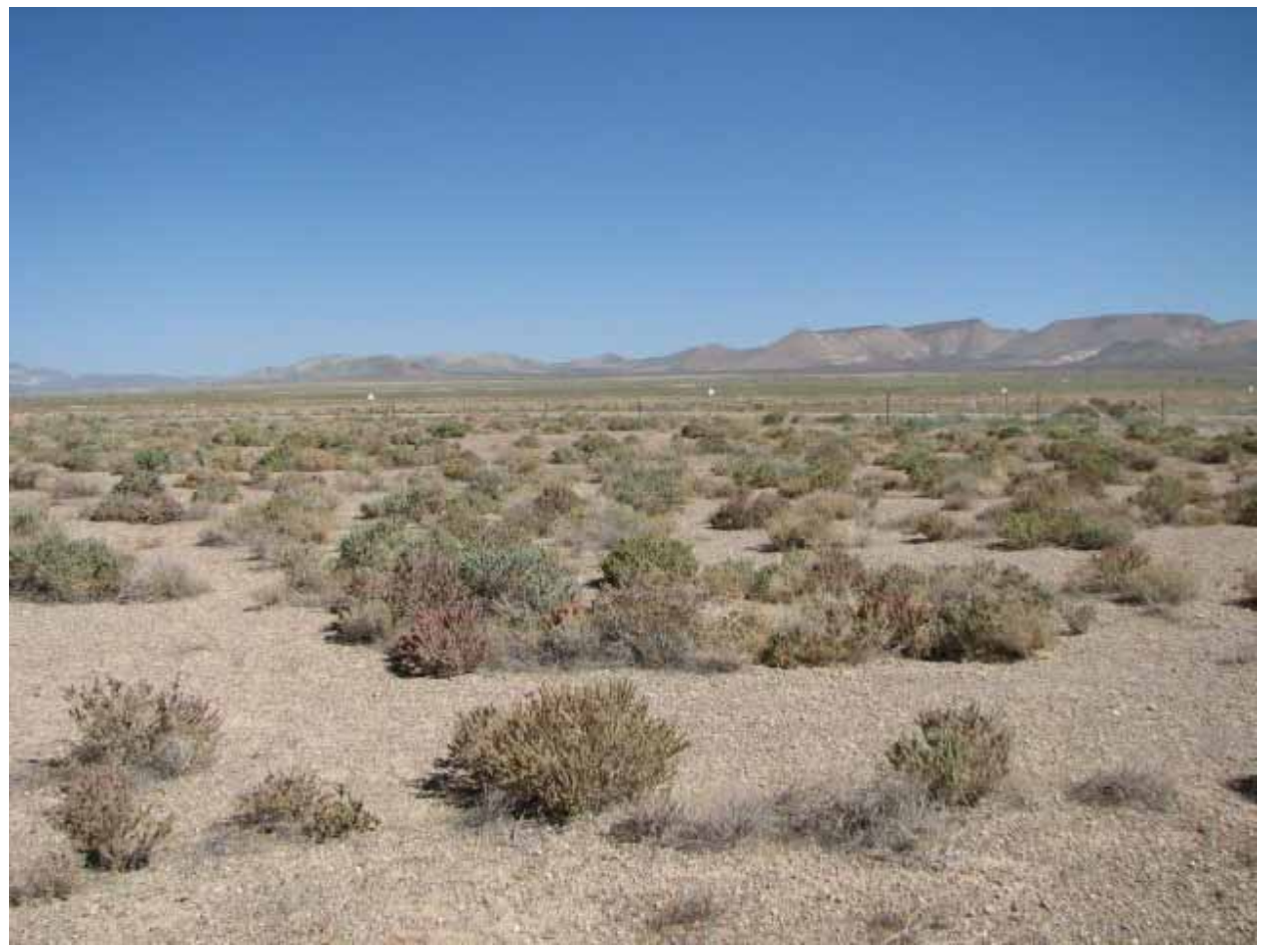

Photograph 89: CAU 110, Inside Facing North, 09/08/2010

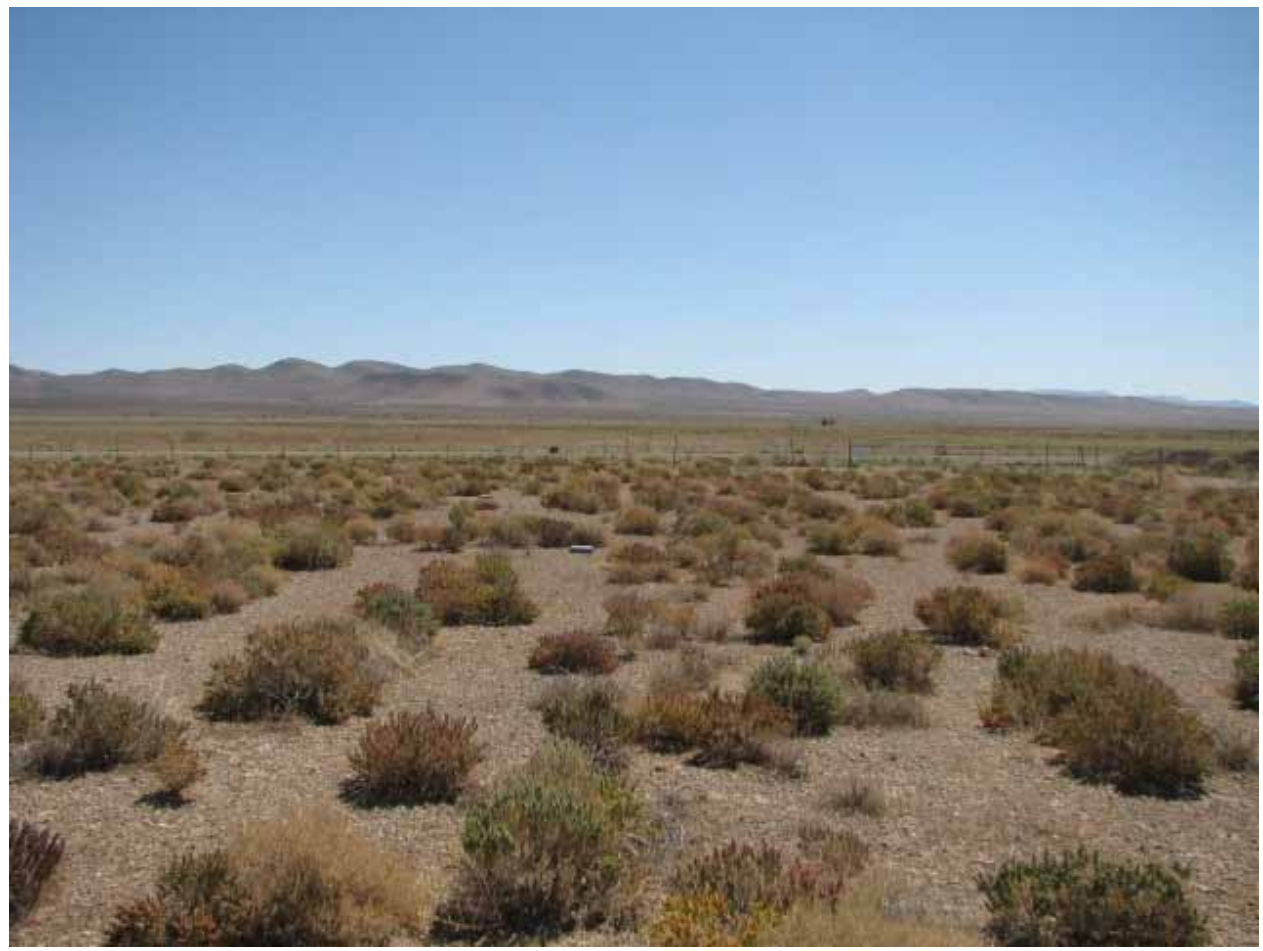

Photograph 90: CAU 110, Inside Facing East, 09/08/2010 


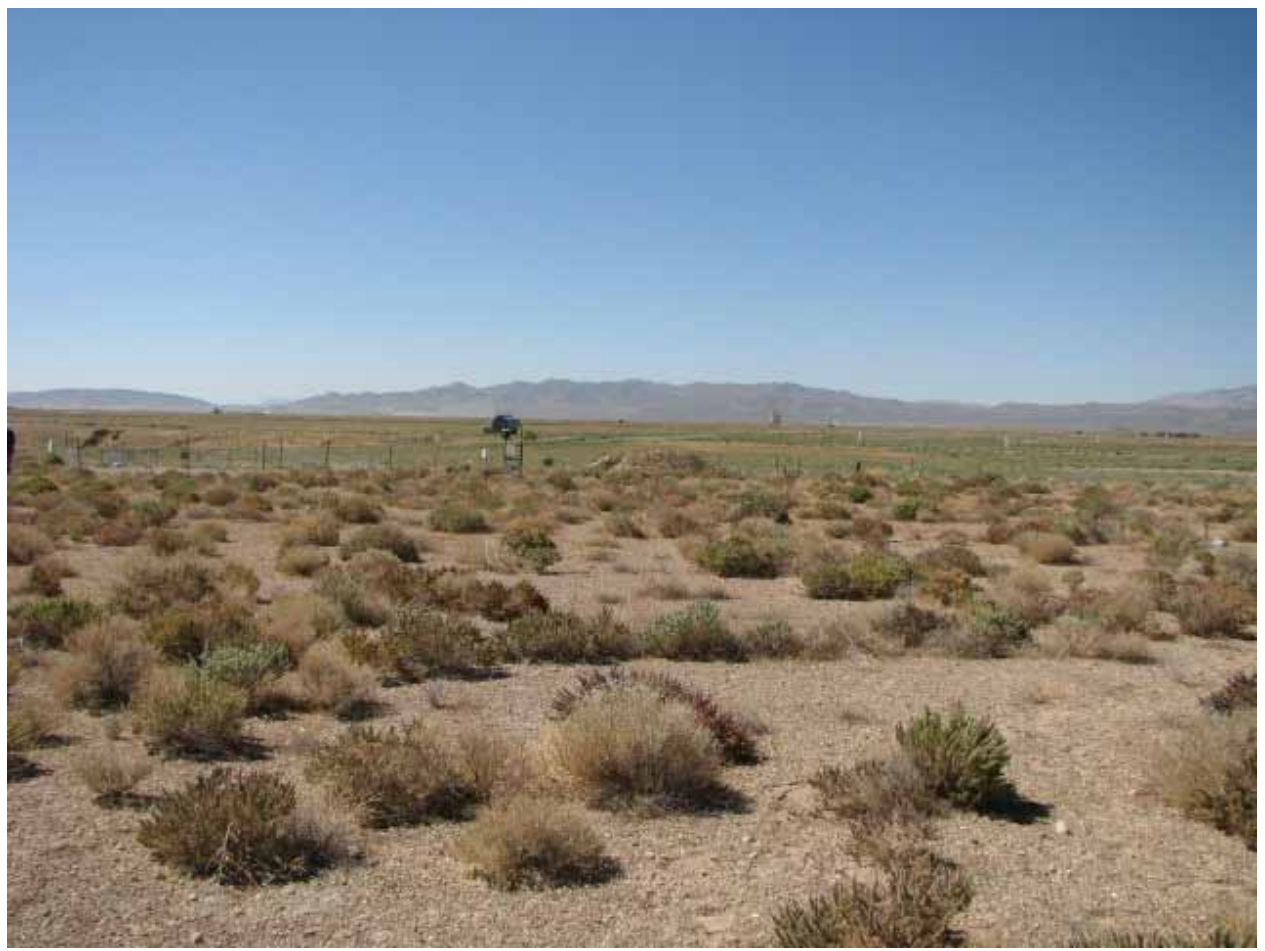

Photograph 91: CAU 110, Inside Facing South, 09/08/2010

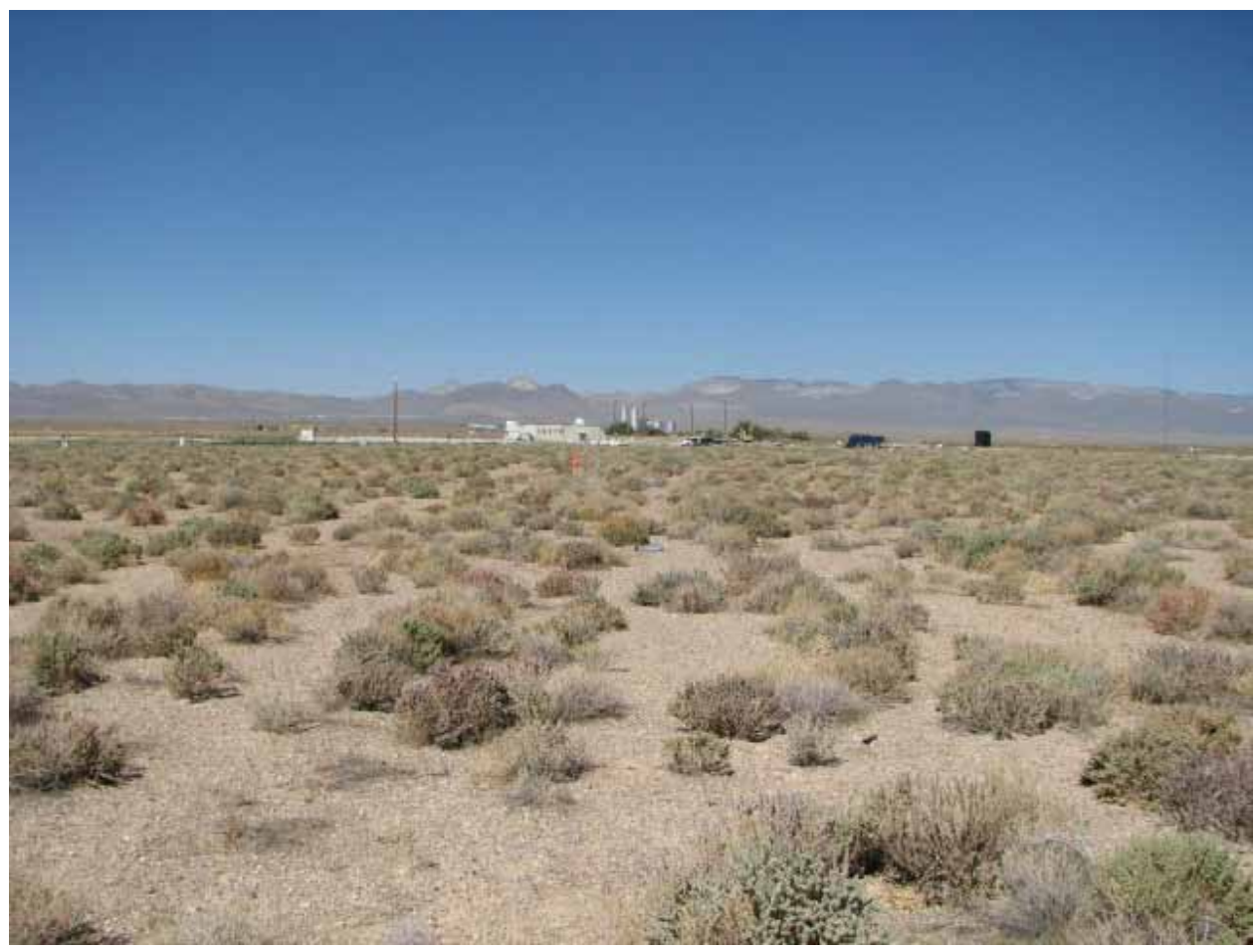

Photograph 92: CAU 110, Inside Facing West, 09/08/2010 


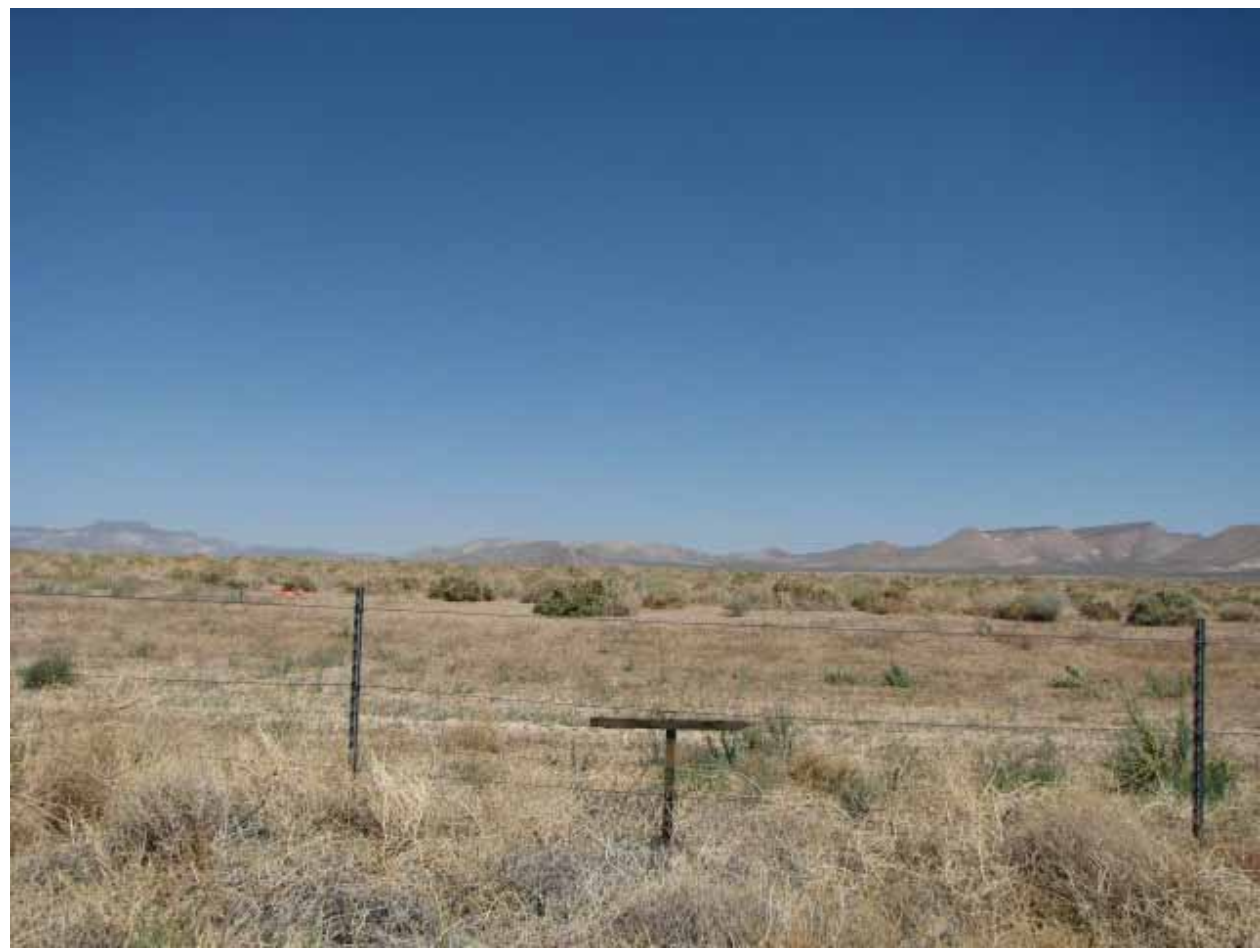

Photograph 93: CAU 110, Outside Facing North, 09/08/2010

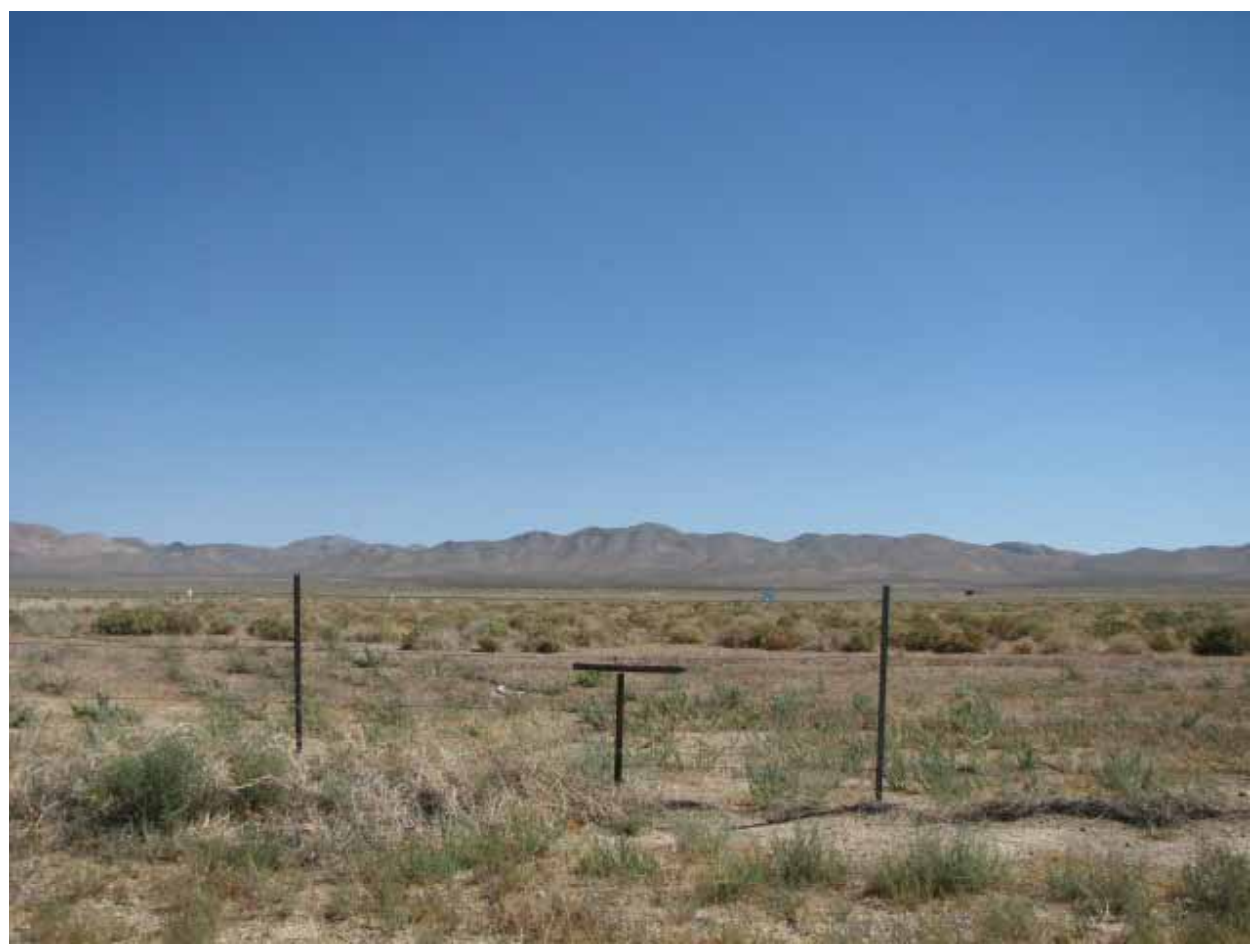

Photograph 94: CAU 110, Outside Facing East, 09/08/2010 


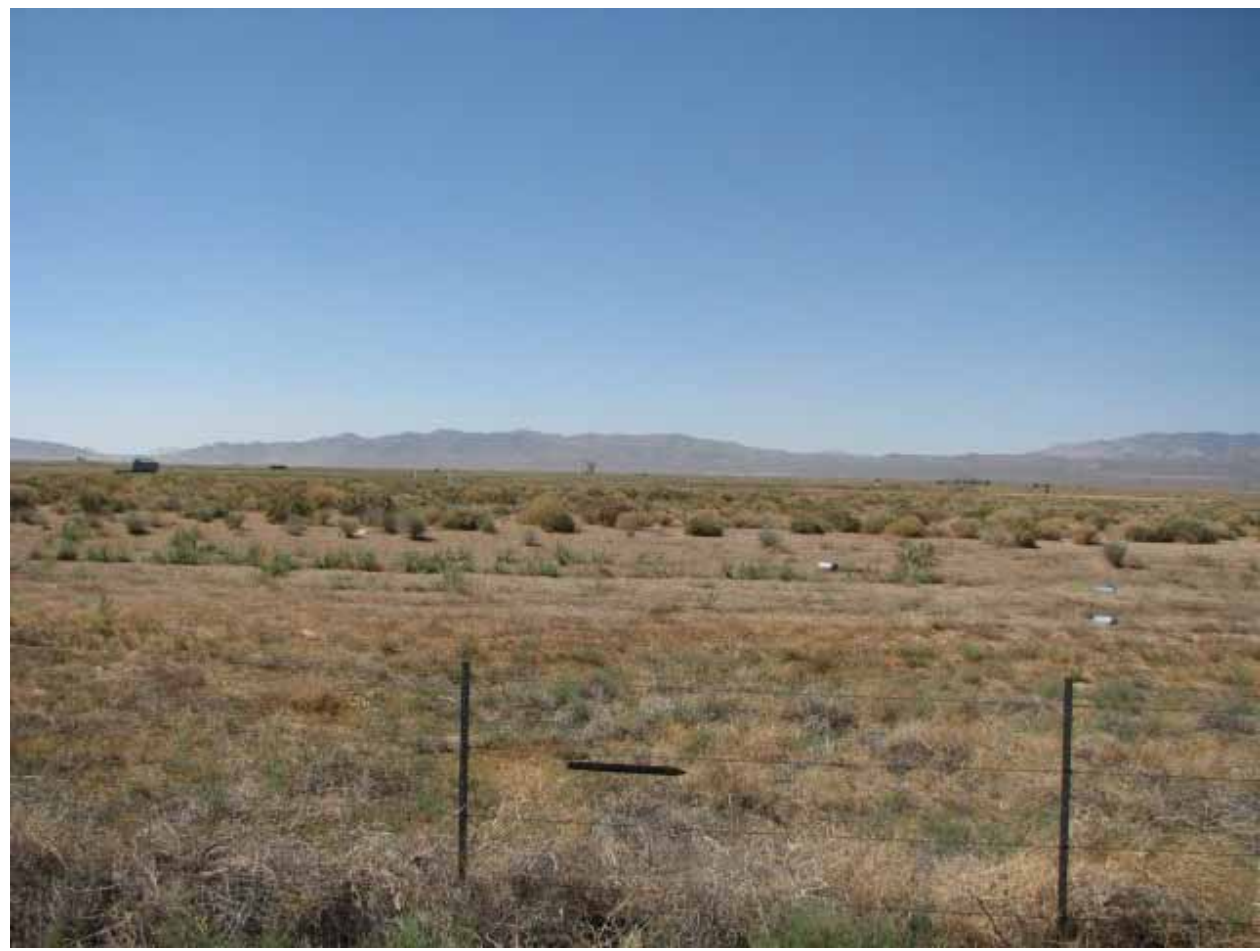

Photograph 95: CAU 110, Outside Facing South, 09/08/2010

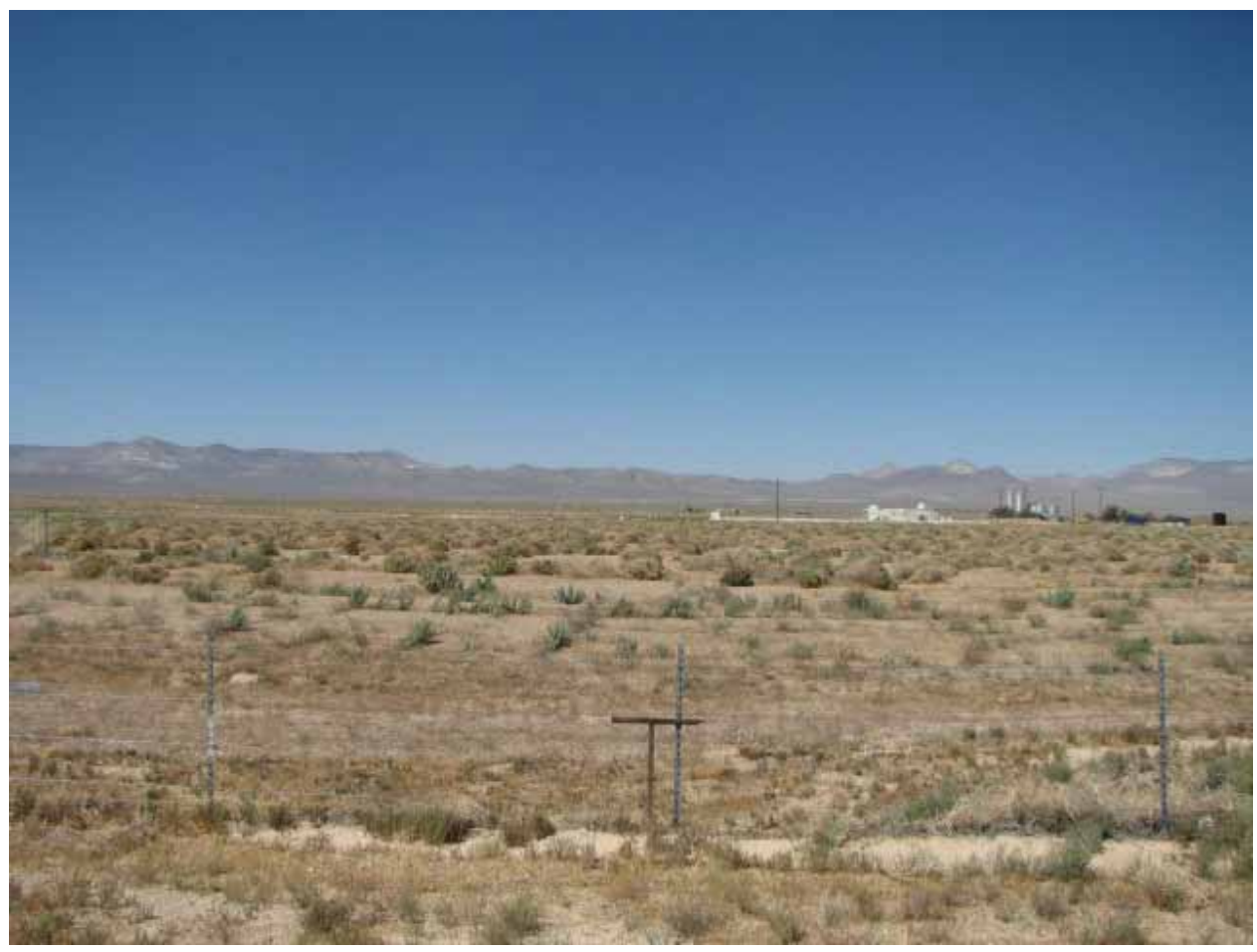

Photograph 96: CAU 110, Outside Facing West, 09/08/2010 
RCRA Post-Closure Report

Revision: 0

Date: January 2011

\section{LIBRARY DISTRIBUTION LIST}


RCRA Post-Closure Report

Revision: 0

Date: January 2011

\section{THIS PAGE INTENTIONALLY LEFT BLANK}




\section{LIBRARY DISTRIBUTION LIST}

U.S. Department of Energy

National Nuclear Security Administration

Nevada Site Office

Technical Library

P.O. Box 98518, M/S 505

Las Vegas, NV 89193-8518

U.S. Department of Energy

Office of Scientific and Technical Information

P.O. Box 62

Oak Ridge, TN 37831-0062

Southern Nevada Public Reading Facility

c/o Nuclear Testing Archive

P.O. Box 98521, M/S 400

Las Vegas, NV 89193-8521

Manager, Northern Nevada FFACO

Public Reading Facility

c/o Nevada State Library \& Archives

Carson City, NV 89701-4285
1 (Uncontrolled, electronic copy)

1 (Uncontrolled, electronic copy)

2 (Uncontrolled, electronic copies)

1 (Uncontrolled, electronic copy) 
RCRA Post-Closure Report

Revision: 0

Date: January 2011

\section{THIS PAGE INTENTIONALLY LEFT BLANK}

